\title{
Corporate investment and liquidity holdings
}

Citation for published version (APA):

Bruinshoofd, W. A. (2003). Corporate investment and liquidity holdings. [Doctoral Thesis, Maastricht University]. Universitaire Pers Maastricht. https://doi.org/10.26481/dis.20030515wb

Document status and date:

Published: 01/01/2003

DOI:

10.26481/dis.20030515wb

Document Version:

Publisher's PDF, also known as Version of record

\section{Please check the document version of this publication:}

- A submitted manuscript is the version of the article upon submission and before peer-review. There can be important differences between the submitted version and the official published version of record.

People interested in the research are advised to contact the author for the final version of the publication, or visit the DOI to the publisher's website.

- The final author version and the galley proof are versions of the publication after peer review.

- The final published version features the final layout of the paper including the volume, issue and page numbers.

Link to publication

\footnotetext{
General rights rights.

- You may freely distribute the URL identifying the publication in the public portal. please follow below link for the End User Agreement:

www.umlib.nl/taverne-license

Take down policy

If you believe that this document breaches copyright please contact us at:

repository@maastrichtuniversity.nl

providing details and we will investigate your claim.
}

Copyright and moral rights for the publications made accessible in the public portal are retained by the authors and/or other copyright owners and it is a condition of accessing publications that users recognise and abide by the legal requirements associated with these

- Users may download and print one copy of any publication from the public portal for the purpose of private study or research.

- You may not further distribute the material or use it for any profit-making activity or commercial gain

If the publication is distributed under the terms of Article $25 \mathrm{fa}$ of the Dutch Copyright Act, indicated by the "Taverne" license above, 
Corporate Investment and Liquidity Holdings 
(C) 2003 Allard Bruinshoofd, Utrecht

All rights reserved. No part of this publication may be reproduced, stored in a retrieval system, or transmitted, in any form, or by any means, electronic, mechanical, photocopying, recording or otherwise, without the prior permission in writing, from the author.

Published by Universitaire Pers Maastricht ISBN 90-9016821-4

Printed in the Netherlands by PrintPartners Ipskamp Enschede Printing and publishing assistance by CopperStudio, Almelo 


\section{Corporate Investment and Liquidity Holdings}

\section{PROEFSCHRIFT}

ter verkrijging van de graad van doctor aan

de Universiteit Maastricht,

op gezag van de Rector Magnificus,

Prof. dr. A.C. Nieuwenhuijzen Kruseman, volgens het besluit van het College van Decanen, in het openbaar te verdedigen op

donderdag 15 mei 2003 om 16.00 uur

door

Allard Bruinshoofd 


\section{Promotor:}

Prof. dr. C.J.M. Kool

\section{Beoordelingscommissie:}

Prof. dr. J. Muysken (voorzitter)

Dr. L. de Haan (De Nederlandsche Bank)

Prof. dr. C.G. Koedijk

Prof. dr. G.A. Pfann 


\section{Acknowledgements}

This work has benefited greatly from cooperative research efforts with Bert Diederen, Clemens Kool, and Wilko Letterie. I want to thank Wilko for the joint research on financing constraints in the Dutch manufacturing sector (Chapter 3) and Bert and Wilko for the joint work on internal capital markets (Chapter 4). I am also grateful for their permission to use our work in this thesis. I thank Clemens Kool for the joint research efforts in identifying the determinants of Dutch corporate liquidity holdings and analysing the adjustment process thereof (Chapters 5 and 6). More generally, I want to thank him for putting his trust in me and providing me with his relentlessly critical comments, yet infinitely patient support throughout.

Chapters 3 through 7 are supported by two grants from the Maastricht research school of Economics of TEchnology and ORganizations (METEOR), which are gratefully acknowledged. Research for these chapters was partially carried out at the CEnter for Research of Economic Micro-data (Cerem) of Statistics Netherlands, for which special gratitude goes to Bert Balk, Jan van den Brakel, and Erik Smeets.

In addition, I want to thank Jaap Bos, Bertrand Candelon, Martin Carree, Leo de Haan, Alain Hecq, Michiel van Leuvensteijn, Gerard Pfann, Katharina Raabe, Jean-Pierre Urbain, and Bas ter Weel for critical comments and valuable discussions on parts of this research. I would also like to thank the members of the reading committee (Leo de Haan, Kees Koedijk, Joan Muysken and Gerard Pfann) for their effort and comments.

Further thanks go to participants of various MiMaMa colloquia and BIRQ seminars; BIRC's seminar on "Investment Decisions by Firms"; the $1^{\text {st }}$ and $2^{\text {nt }}$ seminars on Dutch Micro-Data Research; the NAKE Day 1999 in Rotterdam; seminars at the Department of Finance and Accounting and the Department of Economics of the National University of Singapore; the Conference on Comparative Analysis of Enterprise micro-Data (CAED) 1999 in the Hague; the $6^{\text {th }}$ Spring Meeting for Young Economists 2001 in Copenhagen; the $8^{\text {th }}$ annual meeting of the German Finance Association 2001 in Vienna, and; the European Monetary Forum 2002 in Maastricht.

Last but not least, I want to thank Cora Krijger for technical assistance in preparing the manuscript and getting it to press, Sylvia Beenen and Susan Roggen for secretarial support en Christian Bruinshoofd en Sandor Gunsing 
voor hun commentaar dat de leesbaarheid van de Nederlandse samenvatting sterk verbeterde.

$\mathrm{AB}$, Utrecht, 2003 


\section{Contents}

1 Introduction 1

1.1 Motivation $\ldots \ldots \ldots \ldots \ldots \ldots \ldots \ldots \ldots \ldots \ldots \ldots$

1.2 Aim of the study and place in the literature $\ldots \ldots \ldots \ldots \ldots 2$

1.3 Structure $\ldots \ldots \ldots \ldots \ldots \ldots \ldots \ldots \ldots \ldots \ldots \ldots \ldots$

Part I Informational Problems and Corporate Investment _ 7

$2 \quad$ Investment and Finance 9

2.1 Introduction $\ldots \ldots \ldots \ldots \ldots \ldots \ldots \ldots \ldots \ldots \ldots$

2.2 The theory of investment and financing constraints ....... 11

2.2.1 The Q-model of investment ............... 11

2.2 .2 The Euler-equation approach $\ldots \ldots \ldots \ldots \ldots \ldots \ldots 18$

2.2 .3 Reduced form investment equations . . . . . . . . . 22

2.3 Methodological issues . . . . . . . . . . . . . . . 24

2.3.1 Endogenous regime selection $\ldots \ldots \ldots \ldots \ldots \ldots \ldots 25$

2.3.2 Endogenous changes in internal funds .......... 26

2.3.3 The informational content of financing constraints ..... 28

2.3.4 Binding constraints versus more costly external finance . 29

2.4 Overview of empirical studies $\ldots \ldots \ldots \ldots \ldots \ldots \ldots \ldots \ldots \ldots$

2.4 .1 US evidence $\ldots \ldots \ldots \ldots \ldots \ldots \ldots \ldots \ldots \ldots \ldots \ldots$

2.4 .2 International evidence $\ldots \ldots \ldots \ldots \ldots \ldots \ldots \ldots . \ldots . \ldots 4$

2.5 Do cash flow sensitivities indicate financing constraints? . . . . 44

2.5.1 The Kaplan and Zingales (1997) critique . . . . . . . . 44

2.5.2 Directions for further research $\ldots \ldots \ldots \ldots \ldots \ldots . \ldots 47$

2.6 Summary and conclusions $\ldots \ldots \ldots \ldots \ldots \ldots \ldots \ldots$ 
3 Costly Liquidation and Costly External Finance

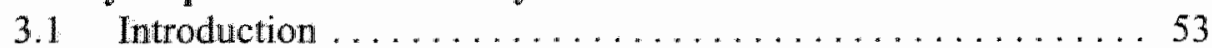

3.2. The empirical investment equation $\ldots \ldots \ldots \ldots \ldots \ldots \ldots, \ldots 5$

3.3 Liquidation, finance, and investment $\ldots \ldots \ldots \ldots \ldots \ldots \ldots 58$

3.3.1 Theoretical considerations $\ldots \ldots \ldots \ldots \ldots \ldots \ldots \ldots . \ldots \ldots$

3.3 .2 The data ........................ 59

3.3.3 Measuring liquidation costs $\ldots \ldots \ldots \ldots \ldots \ldots 60$

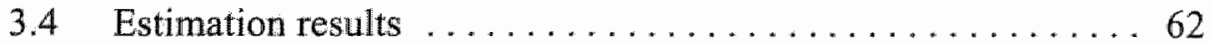

3.4.1 Comovement and financing constraints .........66 62

3.4.2 Comovement: old wine in new bottles? ......... 66

3.4.3 Alternative classifications and financing constraints ... 70

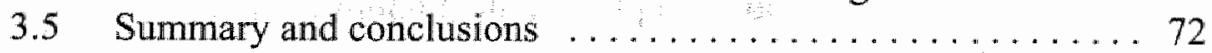

Appendix: Measuring firm-industry sales comovement . . . . . . 73

4 Internal Capital Markets in Dutch Firms 75

4.1 Introduction $\ldots \ldots \ldots \ldots \ldots \ldots \ldots \ldots \ldots \ldots \ldots \ldots$

4.2 The empirical investment equation $\ldots \ldots \ldots \ldots \ldots \ldots \ldots 77$

4.3 Firm diversification $\ldots \ldots \ldots \ldots \ldots \ldots \ldots \ldots \ldots \ldots \ldots$

4.4 Presence of a financial segment $\ldots \ldots \ldots \ldots \ldots \ldots \ldots \ldots$

4.5 The weight of the debt burden $\ldots \ldots \ldots \ldots \ldots \ldots \ldots \ldots . \ldots 87$

4.6 Summary and conclusions $\ldots \ldots \ldots \ldots \ldots \ldots \ldots \ldots \ldots \ldots$

Appendix: The data . . . . . . . . . . . . . . . . . . . 94

Part II Informational Problems and Corporate Liquidity $\quad 97$

5 The Determinants of Dutch Corporate Liquidity 101

5.1 Introduction $\ldots \ldots \ldots \ldots \ldots \ldots \ldots \ldots \ldots \ldots \ldots \ldots$

5.2 The determinants of corporate liquidity $\ldots \ldots \ldots \ldots \ldots \ldots$

5.2.1 Transaction and opportunity costs $\ldots \ldots \ldots \ldots \ldots 103$

5.2 .2 Informational problems . . . . . . . . . . . 104

5.2.3 Pecking order behaviour and buffer stock liquidity . . . 106

5.2.4 Static trade off versus buffer stock and pecking order behaviour ............ 107

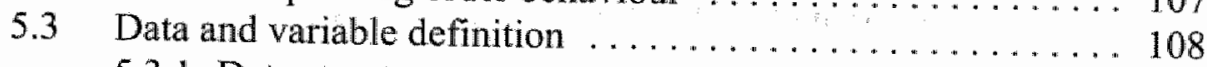

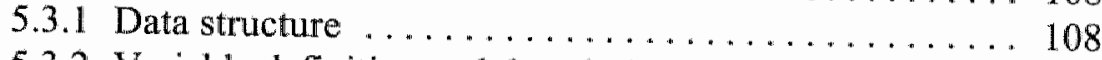

5.3.2 Variable definition and descriptive statistics ........ 109

5.4 Estimation results $\ldots \ldots \ldots \ldots \ldots \ldots \ldots \ldots \ldots \ldots \ldots 11$

5.4.1 The determination of corporate liquidity levels ...... 112

5.4 .2 The determination of corporate liquidity dynamics ... 117

5.5 Summary and conclusions $\ldots \ldots \ldots \ldots \ldots \ldots \ldots \ldots \ldots \ldots$ 
6 The Urgency of Corporate Liquidity Adjustment

6.1 Introduction . . . . . . . . . . . . . . . . . . . . . . 123

6.2 Conditional adjustment incentives ................ 125

6.3 The empirical strategy . . . . . . . . . . . . . . . . . 129

6.4 Does sign matter? . . . . . . . . . . . . . . . . . . 131

6.5 Does size matter? . . . . . . . . . . . . . . . . . 134

6.5.1 A closer inspection of targets and deviations ........ 134

6.5 .2 Asymmetries in size $\ldots \ldots \ldots \ldots \ldots \ldots \ldots \ldots \ldots$

6.6 Summary and conclusions $\ldots \ldots \ldots \ldots \ldots \ldots \ldots \ldots \ldots$

Appendix: (A)symmetries in size for manufacturing

and services firms $\ldots \ldots \ldots \ldots \ldots \ldots \ldots \ldots \ldots \ldots \ldots$

7 Do Corporate Liquidity Holdings Provide Useful

Measures of Financing Constraints? 149

7.1 Introduction . . . . . . . . . . . . . . . . . . . . . . 149

7.2 Liquidity and investment under financing constraints ...... 151

7.2.1 Liquidity and financing constraints: KZ97 . . . . . . 151

7.2.2 A static analysis of liquidity and investment ....... 154

7.2.3 A dynamic analysis of liquidity and investment .... 155

7.2 .4 Empirical hypotheses . . . . . . . . . . . . . 158

7.3 The empirical strategy ..................... 159

7.3.1 Characterising the corporate investment decision . . . 159

7.3.2 Classifications using liquidity, targets, and target deviations . . . . . . . . . . . . . 160

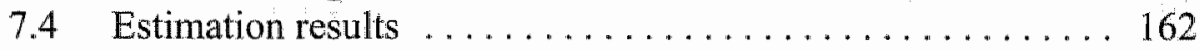

7.4.1 Target deviations and the ICFS ........... 162

7.4 .2 Sensitivity of the results $\ldots \ldots \ldots \ldots \ldots \ldots \ldots$

7.4.3 What information is hidden in observed liquidity holdings? . . . . . . . . . . 167

7.5 Summary and conclusions $\ldots \ldots \ldots \ldots \ldots \ldots \ldots \ldots$

Appendix: Excess ICFS results for manufacturing and services firms 172

$8 \quad$ Summary and Concluding Thoughts $\quad 175$

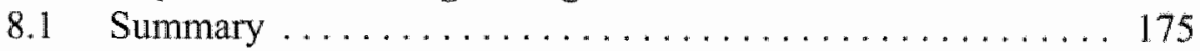

8.2 Further research $\ldots \ldots \ldots \ldots \ldots \ldots \ldots \ldots \ldots \ldots \ldots$

$\begin{array}{ll}\text { References } & 181\end{array}$

$\begin{array}{ll}\text { Samenvatting (Summary in Dutch) } & 191\end{array}$

$\begin{array}{lr}\text { Professional Curriculum Vitae } & 197\end{array}$ 


\section{List of Tables}

2.1 US evidence on financing constraints and investment ......... 34

2.2 International evidence on financing constraints and investment $\ldots \ldots 38$

3.1 Descriptive statistics: $1983-1991 \ldots \ldots \ldots \ldots \ldots \ldots \ldots \ldots \ldots 6 . \ldots 6$

3.2 Sales comovement and financing constraints: $1992-1996 \ldots \ldots \ldots \ldots 64$

3.3 What comovement does not proxy for $\ldots \ldots \ldots \ldots \ldots . \ldots \ldots$

3.4 Alternative classifications and financing constraints: 1992-1996 . . . 71

4.1 Description of variables for the 1996-1998 MICRONOOM sample .. 79

4.2 Segment investment for (un)diversified firms . . . . . . . . . . 82

4.3 Segment investment for firms with(out) financial segments . . . . . 86

4.4 Segment investment for firms with high and low indebtedness . . . . . 91

5.1 Descriptive statistics: $1986-1997 \ldots \ldots \ldots \ldots \ldots \ldots \ldots \ldots \ldots$

5.2 Level estimates of corporate liquidity . . . . . . . . . . . . 113

5.3 Restricted error correction estimates of corporate liquidity . . . . 118

6.1 Level estimates of corporate liquidity: base case results, 1986-1997 . 130

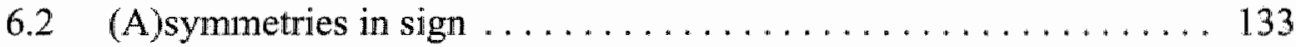

6.3 (A)symmetries in size: all firms $\ldots \ldots \ldots \ldots \ldots \ldots \ldots \ldots \ldots \ldots$

A6.1 (A)symmetries in size: manufacturing firms ............. 145

A6.2 (A)symmetries in size: services firms . . . . . . . . . . 147

7.1 Classifications of firms based on liquidity, targets,

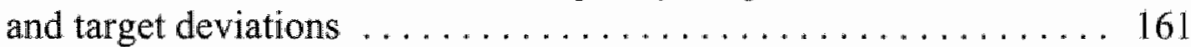

7.2 Target deviations and the investment-cash flow sensitivity . . . . . . 164

7.3 Excess sensitivity related to liquidity holdings, targeted liquidity, and target deviations $\ldots \ldots \ldots \ldots \ldots \ldots$

A7.1 Classifications of manufacturing and services firms based on target deviations .................. 172

A7.2 Excess sensitivity related to target deviations: manufacturing and services firms $\ldots \ldots \ldots \ldots \ldots \ldots \ldots \ldots \ldots \ldots \ldots \ldots \ldots$ 


\section{List of Figures}

1.1 Informational problems, corporate investment, and corporate liquidity holdings $\ldots \ldots \ldots \ldots \ldots \ldots \ldots \ldots \ldots$

2.1 Costly external finance in the Q-model $\ldots \ldots \ldots \ldots \ldots \ldots \ldots \ldots$

2.2 More costly external finance or binding constraints? ......... 30

2.3 Identifying differences in the cost of external finance .......... 31

4.1 Median interest coverage for three balanced panels of firms . . . . 89

5.1 Mean corporate liquidity ratios (in percentages) $\ldots \ldots \ldots \ldots \ldots$

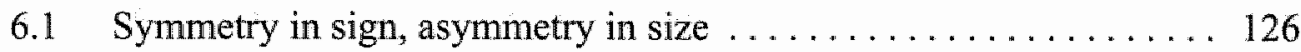

6.2 Asymmetry in sign as well as size $\ldots \ldots \ldots \ldots \ldots \ldots \ldots \ldots .127$

6.3 The distributions of liquidity holdings, targeted holdings, and deviations $\ldots \ldots \ldots \ldots \ldots \ldots \ldots \ldots \ldots \ldots \ldots \ldots \ldots \ldots \ldots \ldots \ldots$

7.1 Liquidity and financing constraints: KZ97 ........... 152

7.2 Informational problems, liquidity holdings, and financing constraints 155

7.3 The value of carrying liquidity from the present into the future ... 157 


\section{Chapter 1 \\ Introduction}

\subsection{Motivation}

Corporate investment and corporate demand for liquidity are areas of continuous research interest. This is easily accounted for considering on the one hand the business cycle impact of cyclical swings in aggregate corporate investment and on the other hand the inflationary implications of aggregate corporate liquidity holdings. As is often the case, however, the human mind is also especially attracted to that which it cannot readily explain. This strongly applies to firm-level research into corporate investment and corporate liquidity holdings.

Regarding the analysis of for example aggregate corporate investment a well-known puzzle pertains the poor relationship between aggregate investment and the cost of capital. Corporate profits perform much better in explaining variations in corporate investment. This is at odds with neoclassical theory, according to which the cost of capital is a sufficient statistic for the explanation of investment and financial information plays no explanatory role at all. Departures from the neoclassical world that allow us to explain these empirical puzzles usually build on capital market frictions and as such imply heterogeneous agents. As a result the representative agent foundation of the empirical analysis into aggregate investment collapses and firm-level analysis is called for.

Similarly, explaining aggregate corporate demand for liquidity is a tedious and low-yielding exercise: aggregate series of corporate liquidity respond poorly to changes in the interest rate, document slow rates of adjustment from out-of-equilibrium liquidity positions, and standard money demand functions leave considerable swings in corporate liquidity holdings unexplained. There is a strong suggestion that firms are also heterogeneous in the way they formulate optimal liquidity holdings and that an aggregate analysis is inappropriate. 


\subsection{Aim of the study and place in the literature}

The aim of this study is therefore to develop an understanding of what drives investment and liquidity decisions of heterogeneous firms. The driving source of firm heterogeneity in this regard stems from informational asymmetries between firms and financial markets, i.e. firms have information that financial markets do not have.

Let us first consider the corporate investment and liquidity decisions in the absence of informational asymmetries so as to motivate our asymmetric information perspective. When information is symmetric and other capital market imperfections are absent, all funds are equally priced, regardless of whether they originate inside or outside of the firm. Hence firms are indifferent between using internal or external funds for the financing of investment. As a result, the investment and financing decisions are independent and investment takes place up to the point where the marginal investment generates zero profits (cf. Modigliani and Miller, 1958). This does not correspond with the empirical finding that the corporate investment decision is sensitive to financial variables (e.g., Meyer and Kuh, 1957), nor is it in line with firms' revealed preference for internal over external funds (e.g., Donaldson, 1961). Capital market perfection furthermore implies that any investment in liquid assets is a zero-profit investment: its marginal cost equals its marginal return, which is the market rate. As such liquidity holdings are mere negative debt and firms have no incentive to invest structurally in liquid assets. This conclusion does not stand up to the empirical observation that firms structurally invest in liquid assets (e.g., Opler et al., 1999). The failure of the perfect capital markets perspective to corroborate basic empirical findings on corporate investment and liquidity holdings motivates the maintained hypothesis of asymmetric information between firms and financial markets in this study.

Informational asymmetries impact importantly on the firm's financing decision: funds now differ in price and/or availability depending on whether they originate inside or outside the firm. Specifically, external finance may now be costly - i.e. command a premium over internal finance - or rationed. A firm is then considered to face financing constraints and this is reflected in its investment and liquidity decisions.

Regarding the corporate investment decision, it is then no longer irrelevant for the firm whether it can finance investment opportunities with

We maintain that informational asymmetries contribute significantly to the explanation of capital market imperfections (cf. Stiglitz, 1992), although we recognise that capital market imperfections may have different origins, such as differential tax treatment of internal versus external financing of investment. 
internal funds only or has to resort to external suppliers of funds as well. In the latter case, there is now a distinct possibility that profitable investment opportunities cannot be initiated because external funds are too expensive or rationed. As a result, then, corporate investment becomes sensitive to changes in internally available funds. There is by now a considerable body of firm-levell empirical studies that investigates the sensitivity of corporate investment to financial variables as a result of informational problems in capital markets. Most studies in this field of research find that the investments of firms that are expected to face (more severe) informational problems in capital markets are more sensitive to the accumulation of internal funds. ${ }^{2}$ A more recent branch of this literature stresses the internal financial organisation of the multi-division firm in the presence of costly or rationed external finance. Intuitively, the reallocation of internal funds between divisions of the same firm, i.e. an active use of the internal corporate capital market, allows the multi-division firm to avoid the walk to external capital markets in more states of the world than the singledivision firm. ${ }^{3}$ Costly external finance is implied by the empirical finding that firms indeed make use of internal re-allocation of scarce internal funds. ${ }^{4}$

Informational problems between firms and financial markets also have repercussions on the corporate liquidity decision. Specifically, liquid assets are now a valuable source of funds for the financing of corporate investment. ${ }^{s}$ This provides firms with an incentive to hold precautionary balances of liquid assets so as to intertemporally minimise the cost of external finance. As such the structural investment in liquid assets for precautionary needs is inherently forward-looking and stems particularly from costly or rationed external finance

2 See for instance Fazzari et al. (1988), Oliner and Rudebusch (1992), Whited (1992), Vogt (1994), Gilchrist and Himmelberg (1995), Hu and Sahiantarelli (1998) for evidence on US data, Schaller (1993) for evidence on Canadian data, Devereux and Schiantarelli (1990) and Bond and Meghir (1994) for evidence on UK data, and Galeotti et al. (1994), Van Ees and Garretsen (1994), Barran and Peeters (1998), Elston (1998) for evidence on various continental European countries.

3 The phrasing is borrowed from Matsusaka and Nanda (2002), p. 176. Also see Stein (1997) and Scharfstein and Stein (2000) for theoretical motivations for firms to develop and use internal capital markets.

4. See for instance Lamont (1997), Stein (1998), Shin and Stulz (1998), Shin and Park (1999), and Peyer and Shivdasani (2001).

5 As already follows from a simple pecking order characterisation of capital structure (e.g., Myers and Majluf, 1984). 
(e.g., Holmström and Tirole, 1998). Empirically, firm-level research on the determinants of corporate liquidity holdings - and specifically the role of informational asymmetries therein - is a rapidly developing area of research.?

A newly developing field of interest concerns the connection between corporate investment and corporate liquidity decisions. ${ }^{8}$ This positions the present study in two innovative, fertile, and expanding fields of firm-level empirical research that are moving towards a crossroads. Furthermore, the empirical application of these issues to the predominantly bank-based Dutch financial system allows us to present and discuss evidence complementary to the literature, which is predominantly US oriented.

\subsection{Structure}

The structure of this study is summarised in figure 1.1 and unfolds in two parts. In part I the corporate investment decision is at the centre of attention. First, chapter 2 reviews the theoretical and empirical literature on firm-level investment in an environment characterised by asymmetric information. Chapters 3 and 4 subsequently contribute to this literature in the following way. In chapter 3, we analyse firm-level investment of large Dutch firms and consider the role of expected liquidation costs in explaining the interdependence of corporate investment and corporate finance. We find that expected liquidation costs are positively related to the dependence of corporate investment on the accumulation of internal funds. This supports the view that liquidation costs are an important impediment for firms who seek external financing for investment. In chapter 4 we take a look inside Dutch conglomerates and examine to what extent the internal capital market is used as

6. Also see Holmström and Tirole (2000) for an explicit role of liquidity holdings in risk management and Holmström and Tirole (2001) for an asset pricing theory based on asset liquidity.

7 See Kim et al. (1998) for the role of capital market frictions in the detrermination of optimal liquidity holdings and Opler et al. (1999) for the specific role of informational asymmetries. Pinkowitz and Williamson (2001) take an international comparative perspective of corporate liquidity determination in bank-based and market-based financial systems, Dittmar et al. (2003) consider the degree of shareholder protection in corporate liquidity demand, and Ozkan and Ozkan (2002) analyse the effects of specific corporate governance structures.

S See Fazzari et al. (2000) and Kaplan and Zingales (2000) for a discussion on this connection and Dasgupta and Sengupta (2001) for a model of simultaneous investment and liquidity decisions. 
a way to get round external financing constraints. Our main result in this regard is that the benefits of the internal capital market can only be achieved through a supportive organisational structure. The majority of firms that we analyse lack such organisational structure and consequently are unable to benefit from the internal re-allocation of funds.

\section{Figure 1.1}

Informational problems, corporate investment, and corporate liquidity holdings

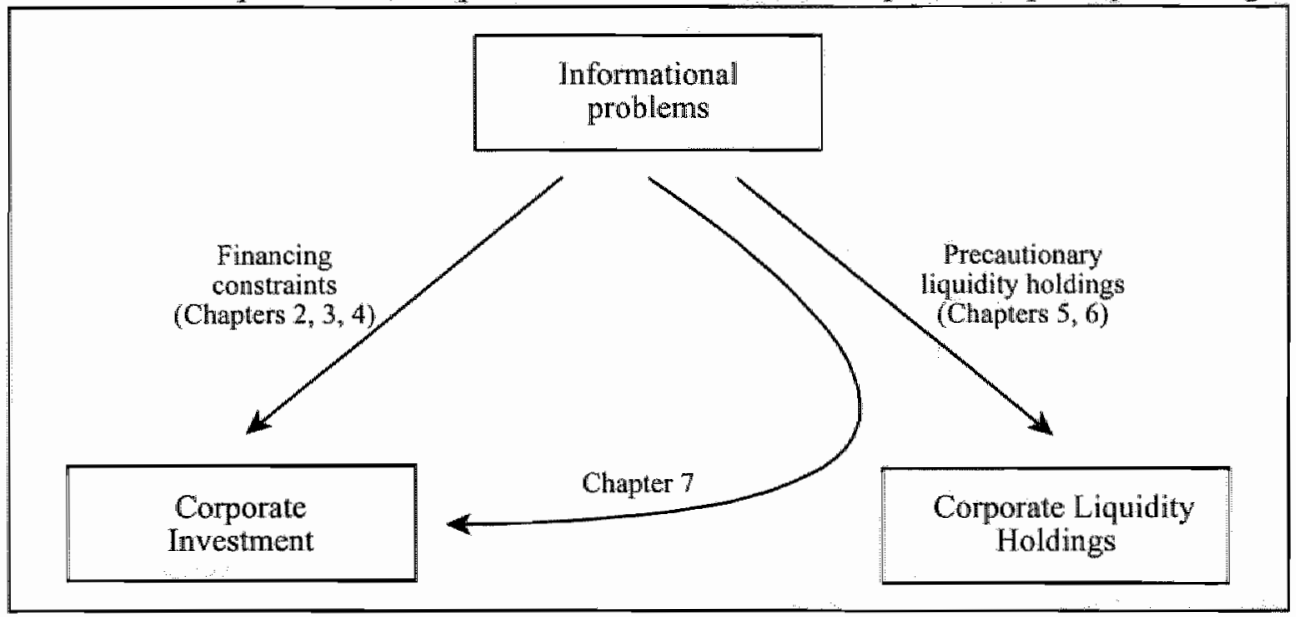

In part II the corporate liquidity decision is at the centre of attention. This attention is undivided in chapters 5 and 6 , in which we analyse the determination of optimal corporate liquidity holdings or targets on the one hand and the speed of adjustment towards target liquidity holdings on the other. From chapter 5, we learn that firms specify long-run liquidity targets and we show that these relate importantly to informational asymmetries between firms and financial markets. In chapter 6 we analyse the adjustment of corporate liquidity holdings from out-of-equilibrium positions. We find that firms routinely accommodate short-run shocks to sources and uses of internal funds. They do so through changes in liquidity holdings, so long as liquidity holdings remain within a certain range around the target. When liquidity has strayed too far from optimal levels, however, short-run adjustment efforts increase considerably. Chapter 7 follows naturally. In it, a connection is established between optimal investment decisions subject to financing constraints and the pursuit of optimal corporate liquidity holdings. We document that firms with a surplus of liquid assets relative to targeted levels - those that have 'free' cash - display a meaningfully lower sensitivity of investment to the accumulation of internal 
funds and vice versa. This supports the conjecture that firms with free cash are less dependent on costly or rationed external finance.

Chapter 8 summarises the main findings, concludes, and provides some directions for future research. 


\section{Part I \\ Informational Problems \\ and \\ Corporate Investment}

When capital markets are perfect, firms are indifferent between using internal and external funds for the financing of investment since both sources of finance are then equally priced. As a result, the investment and financing decisions are independent. However, when capital markets are imperfect and especially when informational asymmetries are present, then the irrelevance theorem no longer holds and investment and finance become connected decisions. Specifically, informational problems make external finance costly, i.e. raise its cost above the opportunity cost of internal finance. The result is that some investment opportunities can no longer be profitably funded with external finance and their initiation depends on the availability of internal finance instead. A firm is then considered to be financially constrained.

Empirically, the explanatory power of financial variables in corporate investment is well documented and dates back to at least Meyer and Kuh (1957). While the positive connection between investment and finance is in line with a financing constraints hypothesis, it cannot discard a simple measurement error explanation. The latter assumes that investment opportunities are imperfectly measured, so that financial variables have informational content in the investment equation and contribute through that channel to the explanation of variations in corporate investment.

In their seminal contribution, Fazzari, Hubbard, and Petersen (1988) propose the following joint hypothesis to empirically demonstrate the relevance of financing constraints in the corporate investment decision. First, they discriminate firms for which they expect informational problems to be most prominent from those for which they expect them to be less prominent. Second, they interpret the differential sensitivity of investment to financial variables of these two sets of firms as a measure of how relevant financing constraints are in corporate investment. Chapter 2 of this thesis provides a comprehensive overview of a broad body of empirical literature that considers this joint hypothesis. Naturally, the power of the proposed empirical test depends on a) how well we are able to sort firms on the basis of (unobservable) informational problems and b) how useful is the sensitivity of investment to financial variables is as a measure of financing constraints? We carefully consider both 
conditions, focus on different theoretical models of investment within which financing constraints can be analysed (e.g., the Q model and the Euler approach), and discuss a wide variety of proposed sorting criteria. At the end of the day, we document a considerable amount of empirical evidence supportive of the hypothesis that financing constraints are especially relevant for firms with weak balance sheets and those with limited reputation in external capital markets.

A relatively small number of studies is increasingly critical of this interpretation of the evidence. These studies, of which Kaplan and Zingales $(1997,2000)$ lead the vanguard, stress the vast amount of internal wealth that some of the supposedly constrained firms have at their disposal. Furthermore, they demonstrate that the sensitivity of investment to financial variables is not a monotonically declining function of the amount of internal wealth. The existence and determination of optimal levels of internal corporate wealth on the one hand and the usefulness of observed levels of internal wealth as measures of financing constraints on the other are as yet unresolved and relatively unexplored research questions. We analysis these questions comprehensively in the second part of this thesis.

In chapter 3 we add to the literature of financing constraints in corporate investment by considering the role of expected liquidation costs in explaining the interdependence of investment and finance. There we measure liquidation costs as the ease with which firms can expect to sell their assets to next-best users, i.e. their industry peers. As such we stress the way the firm relates to its environment in explaining financing constraints regardless of the strength of its balance sheet or its reputation in the external capital markets. We observe that our measure of expected liquidation costs has a strong relationship with the sensitivity of investment to the accumulation of internal funds. This finding supports the hypothesis that liquidation costs signal financing constraints and also emphasises the role of sound collateral in ameliorating informational problems in capital markets.

In chapter 4 , we analyse the optimal internal response of the firm to the external constraint of costly finance. In theory - and in the absence of internal incentive problems - the firm benefits from internal re-allocation of funds between segments, such that the marginal returns on investment are equal across all segments. Put differently, there are benefits from the creation of a capital market within the firm, i.e. an internal capital market. To that end, we examine the financial affairs within multi-segment Dutch firms. We find that the benefits of such an internal capital market are not self-evident, but require a supportive organisational structure. 


\section{Chapter 2 \\ Investment and Finance}

\subsection{Introduction}

The sensitivity of corporate investment to financial variables has been pointed out long ago (e.g., Meyer and Kuh, 1957) and is by now an established fact. It is also well-documented that this sensitivity is more pronounced for certain groups of firms. For instance, Fazzari et al. (1988), FHP88 hereinafter, find that the investment-cash flow sensitivity is stronger for firms with low dividend payout rates; Hoshi et al. (1991) document a lower sensitivity for Japanese firms belonging to a Keiretsu than for independent firms; Whited (1992) reports a stronger sensitivity for firms without a bond rating.

At present, a hotly debated topic is the interpretation of these findings. On the one hand, to the extent that for instance a lemon's premium on external equity raises the marginal cost of equity finance above the risk-adjusted cost of internal capital, a firm faces a wedge between the cost of internal and external finance. Hence it may find itself in a situation where a marginal investment project is sufficiently profitable only when financed with internal funds, except these have been exhausted. The firm is then said to be financially constrained and the implication of the sketched example is that an increase in internal funds will generate an increase in investment that is unrelated to changes in investment opportunities. Hence, FHP88 have claimed that the sensitivity of investment to cash flow is driven by financing constraints resulting from informational problems in the capital markets. FHP88 find supportive evidence for their conjectures sorting US manufacturing firms on the basis of historical track records of dividend payout rates. They find that the cash flow sensitivity of investment is strongest for firms more likely to face financing constraints. Numerous studies have subsequently explored different criteria for the characterisation of constrained firms as well as confronted the framework to data sets from a variety of countries. An extensive survey of empirical studies on financing constraints will follow later, for now it suffices to say that the general finding is that firms characterised as being financially constrained usually display a stronger sensitivity of investment to financial variables.

On the other hand, Kaplan and Zingales (1997) show in a simple theoretical model that the investment-cash flow sensitivity need not be a monotonic function of either internally available funds or the degree of 
informational problems. They also provide empirical results in line with these conjectures, using the sample of financially constrained firms as identified by FHP88. Furthermore, Cleary (1999) presents empirical evidence that suggests that the most financially healthy firms in fact display the strongest sensitivity of investment to cash flow. The proposed explanation of these findings, is that firms with healthy levels of internal funds will have an incentive to use these for (excessive and unprofitable) investment outlays.

This chapter provides a comprehensive overview as well as a critical review of the broad literature that has by now emerged on investment and financing constraints. To this end, both the mainstream research that relates excess sensitivity of investment to financial factors to the working of financing constraints as well as the more recent literature that challenges this methodology will receive explicit attention. The chapter proceeds as follows.

Section 2.2 discusses the theoretical specification of investiment with costly external finance. Here we stress the relation between the choice of specification and the power of the empirical tests of financing constraints. Dynamic investment models considered include the Q-model, the Euler equation approach as well as reduced form investment equations. In section 2.3 we discuss the most important methodological issues in the field of research on financing constraints and investiment. Extensive attention is given to the ways to identify the informational content of the financing constraint, the ways to identify whether the financing constraint is in fact binding; the appropriateness and execution of split sample analysis; and the potential endogeneity of shocks to wealth. We proceed with an extensive overview of empirical studies on financing constraints and investment in section 2.4 and assess the power of the results thereof along the lines of the methodological issues and theoretical considerations discussed. It appears from this survey that 1) the investment-cash flow sensitivity is an empirical regularity; 2) it is more pronounced for firms that can be considered to have a higher probability of facing binding financing constraints, and; 3) on a piecemeal basis, these results stand up to the methodological issues raised. In section 2.5 we discuss a number of more recent studies which have attacked not only the interpretation of cash flow sensitivities in investment equations, but also the premise that more constrained firms should even be expected to exhibit stronger sensitivities. We focus particularly on the scope of the critical comments and challenging findings in relation with the mainstream body of literature on financing constraints and investment. Section 2.6 summarises and concludes. 


\subsection{The theory of investment and financing constraints}

In this section we discuss alternative dynamic capital demand models to derive empirical investment equations in a world with costly external finance. In particular, we discuss the Q-model of investment, the Euler equation approach, and a particular illustration of a reduced form investment model. The focus in the discussion of each is on the strengths and weaknesses regarding the interpretation of empirical tests of financing constraints resulting from modelspecific assumptions.

\subsubsection{The $Q$-model of investment}

The $Q$ approach to characterising investment demand is widely used in the empirical literature on financing constraints and investment. ${ }^{1}$ Its methodological appeal stems from the fact that in the resulting empirical equation, Tobin's $q$ (Tobin, 1969) is a sufficient statistic for investment. Any financial variable that is structurally related to investment (e.g., cash flow, liquidity) can then be interpreted along the lines of costly external finance. For the remainder of this subsection, the $Q$ investment equation is formally derived and its power in assessing the role of financing constraints is discussed.

Let us assume that external finance is costly in the sense that new shares issued $(N)$ yield only a fraction $(1-f)$ of funds. Here $f$ captures the cost discrepancy between a unit of internal funds and a unit of external equity: ${ }^{2}$ Recognising this cost-discrepancy, the value of the firm $(V)$ is expressed as the present value of expected dividend payments $(D)$ less dilution of earnings due to new share issues:

$$
V_{t}=E_{t}\left[\sum_{s=0}^{\infty} \beta_{i+s}\left(D_{t+s}-N_{t+s}\right)\right],
$$

where $D_{t}=\Pi_{i}\left(K_{t}, I_{t}\right)+\left(1-f_{t}\right) N_{i}$ and $E_{t}[$.$] denotes expectations$ conditional on information available at time $t$. Here $\Pi_{t}\left(K_{t}, I_{t}\right)$ is the net revenue function

1 See for instance Fazzari et al. (1988), Hoshi et al (1991), Otiner and Rudebusch (1992), Gilchrist and Himmelberg (1995), Shin and Park (1999), to name just a few. Tables 2.1 and 2.2 below provide a more extensive overview.

The setup is borrowed from Bond and van Reenen (1999). It is a simplified representation of the financing decision that ignores for instance the possibility of debt financing. In addition, alternative specifications of the cost differential are possible. The chosen characterisation can be interpreted as a lemon"s premium on new shares required by investors (cf. Fazzari et al., 1988). 


$$
\Pi_{i}\left(K_{i}, I_{t}\right)=p_{t}\left[F\left(K_{r}\right)-G\left(I_{i}, K_{t}\right)\right]-p_{t}^{K} I_{i},
$$

where $F\left(K_{t}\right)$ specifies the production function, in which we the only input is capital $K_{r}$, and $p_{t}$ is the market price for output, which embodies the demand side of the output market. Gross investment $I_{f}$ is priced at $p_{f}^{K}$ per unit. The net revenue function also includes the capital stock adjustment cost function $G\left(I_{i}, K_{i}\right)$, where costs are cast in terms of lost production and are assumed to be strictly increasing in gross investment around some normal level of investment spending.

Removing dividend payments from equation (2.1) and rearranging terms, we obtain

$$
V_{i}=\Pi_{t}\left(K_{t}, I_{t}\right)-f_{t} N_{t}+\beta_{t+1} E_{t}\left[V_{t+1}\left(K_{t}\right)\right]
$$

where $\beta_{t+1}=1 /\left(1+\rho_{t+1}\right)$ is the firm's discount factor, wherein $\rho$ is the riskadjusted interest rate. The maximisation of the objective function (2.3) is constrained by the equation of motion for the capital stock:

$$
K_{t}=(1-\delta) K_{t-1}+I_{t}
$$

where $\delta$ captures the exogenously given rate of depreciation of capital. With the addition of non-negativity constraints on new share issues $\left(N_{t} \geq 0\right.$, prohibiting share repurchases) as well as dividends payments $\left(D_{t}=\Pi_{t}\left(K_{t}, I_{t}\right)+\left(1-f_{t}\right) N_{t} \geq 0\right)$, the optimisation problem can be represented in the following Lagrangian formulation:

$$
\begin{aligned}
& L=\Pi_{t}\left(K_{t}, I_{t}\right)-f_{t} N_{t}+\beta_{t+1} E_{\mathrm{r}}\left[V_{t+1}\left(K_{t}\right)\right]+V_{t}^{N} N_{t}+ \\
& V_{t}^{D}\left[\Pi_{t}\left(K_{t}, I_{t}\right)+\left(1-f_{t}\right) N_{t}\right]+\lambda_{t}\left[(1-\delta) K_{t-1}+I_{t}-K_{t}\right],
\end{aligned}
$$

where $V_{i}^{N}, V_{t}^{D}$, and $\lambda_{t}$ measure the shadow value of an additional share issued, an extra unit of dividends paid and an extra unit of capital purchased, respectively. The concomitant first-order conditions for investment, capital, and new share issues; after some rearranging of terms, are

$$
\begin{aligned}
& \lambda_{t}=-\left(1+V_{t}^{D}\right) d \mathrm{~J}_{t}, \\
& \lambda_{t}=\left(1+V_{t}^{D}\right) d \mathrm{~J}_{\mathrm{\partial}}+(1-\delta) \beta_{t+1} E_{t}\left(\lambda_{t+1}\right), \\
& -f_{t}+V_{t}^{N}+V_{t}^{D}\left(1-f_{t}\right)=0,
\end{aligned}
$$


where

$$
\lambda_{t}=\frac{1}{1-\delta} \frac{\partial V_{t}}{\partial K_{t-1}} .
$$

The first-order condition for investment (2.6) indicates that investment takes place up to the point where the marginal cost of investment is equal to the shadow value of capital. The economic intuition for equation (2.7) is that from a dynamic point of view the marginal value of a unit of capital must be equal between two adjacent periods of time. Therefore, when deciding to invest at time $t$ or to postpone until $t+1$, the contemporary marginal value of a unit of capital must be raised by a factor that takes into account the value in period $t+1$ of inheriting this one additional unit of capital from period $t$. Lastly, condition (2.8) implies that a firm should never issue new shares and pay dividends at the same time when external finance is more expensive than internal funds. ${ }^{3}$

For the competitive firm, expressions for $-d y / \partial t_{t}$ and $d y / \partial K_{t}$ are derived from net revenue function (2.2):

$$
-\frac{\partial \Pi}{\partial I_{t}}=p_{t}^{K}+p_{t} \frac{\partial G}{\partial I_{t}}
$$

$$
\frac{\partial \Pi}{\partial K_{t}}=p_{t} \frac{\partial F}{\partial K_{t}}
$$

Inserting expression (2.9) into equation (2.6) for $-d y / \partial$, and solving for $\partial C_{\partial t}$ gives

$$
\frac{\partial G}{\partial I_{t}}=\left(\frac{q_{t}}{1+V_{t}^{D}}-1\right) \frac{p_{t}^{K}}{p_{t}}
$$

where

$$
q_{t}=\lambda_{p_{g}}
$$

3. First, consider a firm issuing new shares, so that the non-negativity constraint on new share issues does not bind and $V_{t} \vec{N}=0$. Equation $(2,8)$ then defines a strictly positive shadow value for dividend payments: $V_{t}^{D}=\frac{f_{t}}{i-y_{t}}$. Hence dividend payments are costly when new shares are being issued. Second, consider a firm paying dividends. Now, the nonnegativity constraint on dividends does not bind and the shadow value of dividend payments is zero $\left(V_{*}^{D}=0\right)$. Equation $(2.8)$ defines a strictly positive shadow value for new share issues in this case: $V_{t}^{N}=f_{t}$. Hence new share issues are costly when dividends are being paid. In summary, then, it is costly for a dividend paying firm to issue new shares, while dividend payments themselves are costly when the firm issues new shares. 
Since we have assumed that marginal adjustment costs $\left(\partial \sigma_{t}\right)$ are strictly convex in gross investment, equation (2.11) states that both are positive when $q_{t} / 1+V^{b}$ exceeds unity. For a positive shadow value of dividends (i.e. external finance is costly and the non-negativity constraint on dividends binds) this implies a threshold value for $q_{i}$ that is strictly larger than unity. Whenever $V_{i}^{b}=0$, however, the firm invests up to the point where $q_{i}=1$. This is crucial in the understanding of why costly external finance makes the investment and financing decisions non-separable. We return to this point shortly.

Empirical implementation of (2.11) requires explicit characterisation of $\partial G / \partial$, as well as a measure for marginal $q$. Regarding the former, we assume the Summers (1981) constant returns-to-scale adjustment cost function to hold:

$$
G\left(I_{l}, K_{t}\right)=\frac{b}{2}\left[\left(H_{K}\right)_{t}-a\right]^{2} K_{i}
$$

in which adjustment cost are quadratic around some normal investment level (or bliss point) and are symmetric. ${ }^{4}$ Rearranging terms, differentiating with respect to gross investment $\left(I_{t}\right)$, and solving for the investment rate $(I / K)$, results in investment equation (2.13), which relates the investment rate directly to the value of $q_{r}$.

$$
\left(\frac{I}{K}\right)_{t}=a+\frac{1}{b} \frac{p_{t}^{K}}{p_{t}}\left(\frac{q_{t}}{1+V_{t}^{D}}-1\right)
$$

Regarding an empirical expression for marginal $q$, the equality between average and marginal $q$ is exploited. The requirement for this equality is that the net revenue function (2.2) is homogeneous of degree one in simultaneous and proportional increases in gross investment and the capital stock (see Hayashi, 1982), the sufficient condition for which is constant returns to scale in

4 Admittedly, following Pindyck's (1991) seminal contribution on the role of irreversibilities on the investment decision under uncertainty, the symmetric convex adjustment cost function has lost much of its intuitive appeal. Hamermesh and Pfann (1996), more specifically, consider asymmetric as well as lumpy adjustment costs. Especially the latter allows for a prominent role of sunk costs, partial irreversibilities and concomitant real options in the investment decision. Stich richer characterisation of the investment decision typically pertains to individual. investment projects and empirical applications include case study (eg. Brennan and Schwartz, 1985) and plant level investment analysis (eg. Caballero et al., 1995). At the firm-level, however, we assume that the symmetric convex adjustment cost function is still a sufficient approximation of the true adjustment cost technology. 
the production and adjustment cost functions and a price-taking firm. Under these conditions, we can write

$$
\frac{q_{i}}{1+V_{i}^{D}}=\frac{V_{t}}{(1-\delta) p_{t}^{K} K_{t-1}} .
$$

Assuming efficient stock markets, the value of the firm can be measured using stock market valuation. The direct result from (2.14) is that for $V_{t}^{D}=0, q_{\text {, is }}$ equal to the external value of the firm relative to the replacement cost of the capital stock it inherits from the previous period. For positive $V_{t}^{D}$, however, a wedge is driven between the external value of the firm and its replacement value of capital. In terms of equation (2.13) this implies that for some $q_{t}>1$ the external value of the firm exceeds the replacement cost of capital, yet not by a sufficiently large fraction to compensate for the cost of raising external finance to fund a capital stock expansion. At the same time, such scale expansion can be profitably conducted when sufficient internal funds are available, i.e. the nonnegativity constraint on dividends does not bind and $V_{t}^{D}=0$. The investment decision then depends on the extent to which the firm is forced to rely on external funds in the financing of investment.

In particular, for any given amount of internal funds $W$ and an external finance cost premium $f$, we identify three financing regimes in figure 2.1. For a sufficiently low investment demand relative to internally available funds $I_{L(\text { ow })}$ - the firm has sufficient retained earnings to finance planned investment and pay a positive dividend. Since this implies a zero shadow value for dividend payments, the firm invests up to the point where $q_{t}=1$. An increase in internal

5 For a critical analysis of the further, implicit assumptions required for this equality to hold, see for instance Chirinko (1987).

We can multiply equation (2.6) by $I_{1}$, equation (2.7) by $K_{\text {, }}$, and combine them to obtain

$$
\frac{\lambda_{i}}{1+y_{s}^{m}}\left(K_{t}-I_{i}\right)=\frac{\partial \|}{\partial I_{t}} I_{t}+\frac{\partial M}{\partial K_{i}} K_{t}+\beta_{i+1} E_{t}\left[(1-\delta) \lambda_{t+1} K_{t}\right]
$$

Inserting the equation of motion for capital (2.4) and exploiting firom the constant returns propenty of the net revenue function that $\frac{\partial \Pi}{\partial I_{i}} I_{t}+\frac{\partial \Pi}{\partial K_{f}} K_{l}=\Pi\left(K_{t}, I_{l}\right)$, we get

$$
\frac{\lambda_{t}}{1+W_{i}^{D}}(1-\delta) K_{t-1}=\Pi_{t}\left(K_{t}, I_{t}\right)+\beta_{t+1} E_{t}\left[(1-\delta) \lambda_{t+1} K_{t}\right]
$$

which can be solved forward for $\lambda_{t+1}$ and rearranged to obtain (2.14) where

$$
V_{t}=E_{t}\left[\sum_{s=0}^{\infty} \beta_{t+s} \Pi_{t+s}\left(K_{t+s}, I_{t+s}\right)\right]
$$


funds does not change the investment decision: the firm is unconstrained and chooses the first-best investment level $\left(V_{K}\right)_{L}^{*}$.

\section{Figure 2.1}

Costly external finance in the Q-model

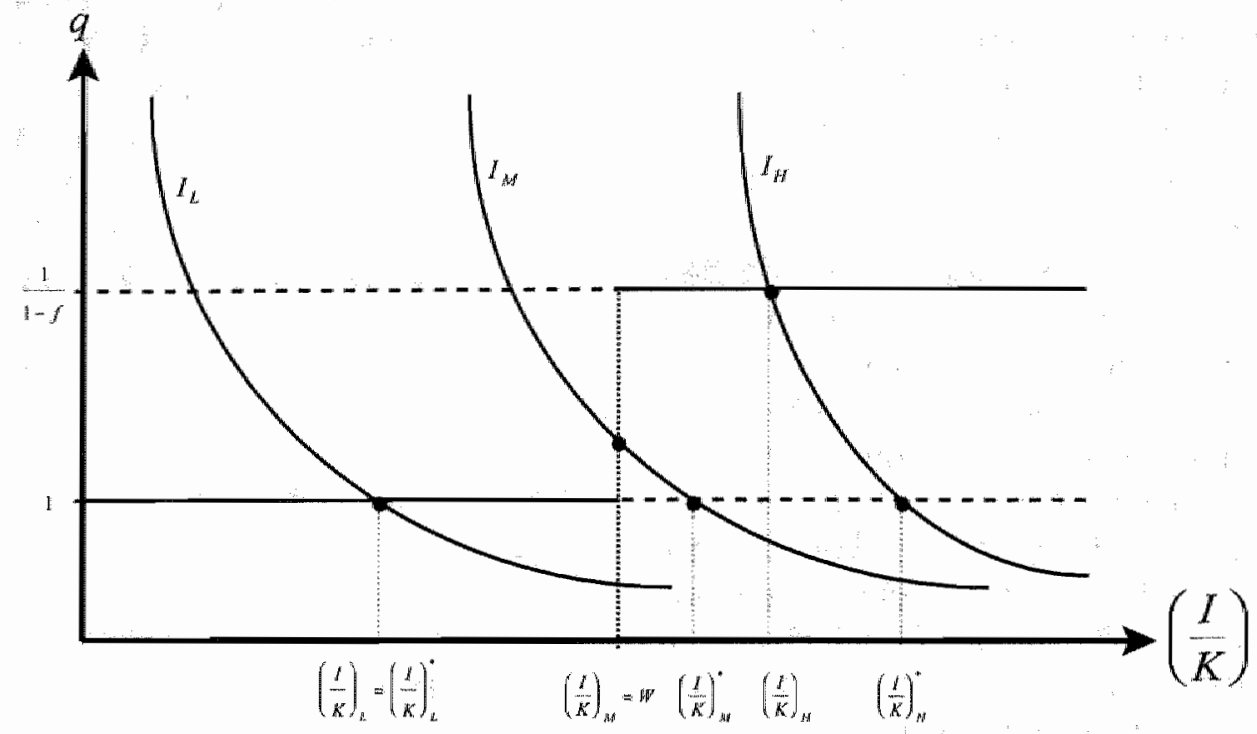

Source: Adapted from Fazzari, Hubbard, and Petersen (1988), p. 156.

In contrast, consider a firm with insufficient retained earnings to finance all planned investment, but for which the marginal investment project is sufficiently profitable that it can be financed through a new share issue, i.e. $I_{H(i g h)}$. For this firm the shadow value of new share issues is zero, while paying dividends is costly. Hence from equation (2.8) it follows that the firm expands its capital stock up to the point where $q_{i}=1 / 1-f_{t}$. The firm is then constrained in the sense that it invests less than the optimal amount: $\left(V_{K}\right)_{H}<\left(V_{K}\right)_{H}$. Furthermore, it funds investment with $\left(V_{K}\right)_{H}-W$ of external funds and depletes internal funds $W$. In future periods, therefore, the firm will have its capital stock move along the expansion path as set out and constrained by the generation of internal funds.

For firms with an intermediate investment demand relative to internal funds $-I_{M(\text { edium })}$ - the investment decision is particularly sensitive to changes in internal funds. These firms invest $W<\left(L_{K}\right)_{M}$ and find that the marginal project cannot profitably be financed with new share issues (since $q_{\ell}<1 / 1-f_{t}$ ), while at the same time it is never optimal for the firm to forego investment for 
the sake of paying dividends (since $q_{r}>1$ ). Positive shocks to internal funds will thus feed into increased investment outlays for these firms.

Taken together, we expect the investment decision to depend on the availability of finance for firms with an intermediate or high investment demand relative to internal funds, whereas $q_{t}$ is a sufficient statistic for firms with a relatively low investment demand. The empirical strategy to illustrate the importance of financing constraints in a Q model of investment is therefore to estimate the following regression equation:

$$
\left(\frac{I}{K}\right)_{t}=\beta_{0}+\beta_{1} Q_{t}+\beta_{2}\left(\frac{C f}{K}\right)_{t}+\varepsilon_{t},
$$

where

$$
Q_{t}=\frac{p_{t}^{K}}{p_{t}}\left(\frac{V_{t}}{(1-\delta) p_{t}^{K} K_{t-1}}-1\right)
$$

and $C f$ measures cash flow. By equation (2.13), $E\left[\beta_{0}\right]=a$ and $E\left[\beta_{1}\right]=1 / b$. Furthermore, when firms can finance all planned investment with internal funds, $E\left[\beta_{2}\right]=0$ and $Q_{t}$ is a sufficient statistic. ${ }^{7}$ However, when firms' investment demand is such that costly external finance must be raised, investment and finance become non-separable in the sense that the generation of internal funds (cash flow) impacts on investment, i.e. $\beta_{2}>0$.

FHP88 estimate equation (2.15) separately for firms expected to be financially constrained (those with intermediate or high investment demand) and unconstrained (those with low investment demand). The observation that financial variables impact on investment for both groups of firms is in line with the earlier empirical findings and does not provide conclusive information regarding the relevance of financing constraints. ${ }^{8}$ However, their observation that $\beta_{2}^{C}-\beta_{2}^{U C}>0$, implies that constrained (C) firms exhibit a stronger sensitivity of investment to cash flow than unconstrained (UC) firms. This is a result that does suggest costly external finance.

7 Note that we assume $f>0$. Of course, a firm's investment decision should also be insensitive to cash flow when $f=0$, regardless of whether the firm needs to raise external finance.

8 The finding that cash flow matters in investment equations is general and dates back at least to Meyer and Kuh (1957). In particular, empirical results for $\mathrm{Q}$ models of investment suggest that the explanatory power of $\mathrm{Q}$ is very low and the implied adjustment cost parameter $(b)$ implausibly high. This finding may reflect mismeasurement of $Q$, which results in financial variables being correlated with unobserved innovations in investment opportunities. Hence, positive estimates of $\beta_{2}$ by themselves do not necessarily reflect costly external finance. 
A particular problem to which the FHP88 methodology may be liable pertains to the possibility that mismeasurement in $Q$ is systematically related to the criteria used to identify financially constrained firms. ${ }^{9}$ Specifically, the classification considered by FHP8 8 is based on firms' retention practice, arguing that finaneing constraints matter most for firms that plow back large fractions of profits. However, let us consider the following scenario. First, assume that $\mathrm{Q}$ measures investment opportunities imperfectly and let cash flow as a result thereof contain information on investment opportunities that are not captured in Q. Second, assume that firms facing a positive shock to investment opportunities choose to increase the retention rate of profits. These two assumptions together result in firms with unobserved positive shocks to investment opportunities self-selecting into the high retention regime while at the same time their cash flow is correlated with investment expenditure due to its informational content. The empirical observation that the investment of high retention firms displays excess sensitivity to cash flow can then be explained by differences in the informational content of cash flow between high and low retention firms, rather than the presence of binding financing constraints.

While it is not easy to control for this problem, we will discuss the issue as well as proposed solutions at more length in the next section. Alternatively, we may choose to avoid the measurement problem altogether and analyse investment behaviour within the Euler equation approach.

\subsubsection{The Euler-equation approach}

The Euler equation offers two interesting features compared to the Q-model. First, a number of restricting assumptions, required to derive the basic Q-model, are redundant. In particular, the net revenue function need not exhibit constant returns to scale and imperfect competition is allowed. ${ }^{10}$ Second, there is no need to derive information from the stock market since the Euler equation does not include $\mathrm{Q}$. This latter feature is of course the most important one in the light of

9 This argument was first raised by Blinder (1988) in his discussion of the FHP88 paper and further elaborated upon by Hoshi et al. (1991) and Gilchrist and Himmelberg (1995).

10 In the empirical analysis, the validity of these assumptions can be assessed by estimating the respective parameters. For instance, Hubbard et al. (1995) and Jaramillo et al. (1996) estimate the mark-up over cost to assess market power and Whited (1992) estimates both the mark-up and returns-to-scale parameters. 
the ambiguity regarding the interpretation of investment-cash flow sensitivities in the Q-model. ${ }^{\text {II }}$ The former feature is of secondary importance in that regard.

In fact, in order to keep the Euler equation analytically 'close' to the Qmodel developed above, the former will be developed under the same set of assumptions as the latter, considering the maximisation problem outlined in equations (2.1) - (2.8). Contrary to the $Q$ model, however, we now equate firstorder conditions (2.6) and (2.7) to remove $\lambda_{t}$ from the problem:

$$
-\left(1+V_{t}^{D}\right) \frac{\partial \Pi}{\partial I_{t}}=\left(1+V_{t}^{D}\right) \frac{\partial \Pi}{\partial K_{t}}+(1-\delta) \beta_{t+1} E_{t}\left(\lambda_{t+1}\right)
$$

Given the net revenue function (2.2) and assuming perfectly competitive markets, we can insert equations (2.9) and (2.10) for $-d y$, and $d y / \partial K_{4}$, respectively. We then obtain the marginal adjustment cost of investment

$$
\frac{\partial G}{\partial I_{t}}=E_{t}\left[\frac{\psi_{t+1}}{1+V_{t}^{D}} \frac{\partial G}{\partial I_{t+1}}\right]+\left[\frac{\partial F}{\partial K_{t}}-\frac{\partial G}{\partial K_{t}}-\left(\begin{array}{c}
r \\
p
\end{array}\right)_{t}\right],
$$

where

$$
\psi_{t+1}=\left(\frac{1-\delta}{1+r_{t+1}}\right) \frac{p_{t+1}}{p_{t}}
$$

Comparing equations (2.17) and (2.11) - the latter depicts $\partial \sigma / \partial$ in the Q-model - we observe that the right-hand side variables in both equations contain essentially the same information. In particular, the evaluation of the marginal effect of investment on adjustment costs in equation (2.17) takes into account not only the current marginal productivity of capital, it also considers the expected marginal adjustment costs in $t+1$. In essence, then, all information regarding future profitability is captured by the one-step ahead forecast of marginal adjustment costs. ${ }^{12}$ Hence, the main advantage of the Euler approach

1 This feature is also valued highly when the analysis focusses on firms in developing economies, where stock market information is liard to come by and hence $Q$ is obtained with high probability of measurement error or not al all (e.g., Jaramillo et al., 1996). But the methodological concerns with the Q-model have also made the Euler-equation approach a frequently used tool in the analysis of investment of firms in economies with a well-developed stock market (e.g., Whited (1992) and Hubbard et al. (1995) for the US and Bond and Meghir (1994) for the UK).

12 Solving (2.17) forward for $\partial O \partial_{t+1}$ gives an expression which has essentially the same interpretation as $q_{1} /\left(1+V_{n}^{b}\right)$ in equation $(2.11)$ : 
stems from the fact that the one-step ahead forecasts of marginal adjustment costs are less prone to problems of mismeasurement than is the shadow value of capital that plays a pivotal role in the Q-model.

The interpretation of the role of $V_{t}^{D}$ in equation (2.17) is the following: if the firm faces a binding financing constraint (ice internal funds are low enough that it has to rely on more expensive externa $\rrbracket$ finance), the firm behaves as if it has a higher discount rate (analogous to Hubbard et al. (1995) and Whited (1992)). Put differently, the premium paid for external funds makes the firms less considerate about inter-temporal minimisation of adjustment costs. ${ }^{13}$

We differentiate the Summers (1981) adjustment cost function (equation (2.12)) for $t+1$ with respect to $I_{t+1}$. This gives an expression for $\partial G / \partial t_{t+1}$ in (2.17). Subsequently differentiating equation (2.12) with respect to $I_{t}$, solving for $\left(V_{K}\right)_{t}$, and inserting into $(2.17)$ for $\partial \sigma_{/} x_{i}$ produces the Euler equation with costly external finance:

$$
\begin{aligned}
& \left(\frac{I}{K}\right)_{t}=a\left[1-E_{t}\left(\frac{\psi_{t+1}}{1+V_{t}^{D}}\right)\right]+E_{t}\left[\frac{\psi_{t+1}}{1+V_{t}^{D}}\left(\frac{I}{K}\right)_{t+1}\right] \\
& +\frac{1}{b}\left[\frac{\partial F}{\partial K_{t}}-\frac{\partial G}{\partial K_{t}}-\left(\frac{r}{p}\right)_{t}\right] .
\end{aligned}
$$

Like in the Q-model, the investment decision thus depends on whether the financing constraint is binding. If the firm has sufficient internal funds available to finance planned investment and pay dividends as well, it will invest according to equation (2.18) with $V_{d}^{D}=0$. However, if the firm has insufficient internal funds to finance all planned investment (i.e. it has an intermediate or high investment demand as defined in figure (2.1)), the nonnegativity constraint on dividends becomes binding, the firm pays no dividends, and invests according to equation (2.18) with $V_{t}^{D}>0$.

Now inserting $f_{y} / 1-f_{t}$ for $V_{t}^{D}$ in equation (2.18) and assuming rational expectations - so that the expectations terms can be replaced by realised values plus a prediction error - we obtain an empirical specification in which the presence of financing constraints can be examined using standard specification tests:

$$
\sum_{s=1}^{\infty} \frac{\Psi_{i+s}}{\left(1+Y_{1+s}^{\infty}\right)}\left(\frac{\partial F}{\partial K_{t+s}}-\frac{\partial G}{\partial K_{t+s}}-\left(\frac{r}{p}\right)_{t+s}\right)
$$

13 As Whited (1992) puts it: "(c/ompared to an unconstrained firm, a firm facing a binding liquidity constraint [...] incurs a higher marginal opportunity cost of investment roday versus delaying it until tomorrow" (p. 1433). 


$$
\begin{aligned}
& \left(\frac{I}{K}\right)_{t}-a\left[1-\psi_{t+1}\right]-\psi_{t+1}\left(\frac{I}{K}\right)_{i+1}-\frac{1}{b}\left[\frac{\partial F}{\partial K_{t}}-\frac{\partial G}{\partial K_{t}}-\left(\frac{r}{p}\right)_{i}\right] \\
& =a f_{i} \psi_{t+1}-f_{t} \psi_{t+1}\left(\frac{I}{K}\right)_{t+1}+e_{t+1} .
\end{aligned}
$$

Estimating equation (2.19) using the generalised method of moments and an optimal set of valid instruments for the explanatory variables implies that the presence of financing constraints can be assessed by the correlation between the instruments and the right-hand side of the equation. Given valid instruments, the null hypothesis of perfect capital markets, $H_{0}: f_{i}=0$, can be assessed using a standard specification test. ${ }^{14}$ Under the null, the right-hand side of equation (2.19) is white noise and uncorrelated with the set of instruments, i.e. tests for over-identifying restrictions cannot be rejected. Under the alternative, $H_{a}: f_{t}>0$, the right-hand side does not only contain a white-noise error term, but also a component that consists of left-hand side variables and is therefore by definition correlated with the instrument set. Hence, the test of over-identifying restrictions will be rejected. This approach to evaluate the presence of binding financing constraints in an Euler-equation approach is labelled the 'Eulerequation mis-specification approach" (cf. Galeotti et al., 1994). In essence, this approach is able only to identify the presence, but not the nature of the financing constraints. The nature of the constraints can be analysed if they are explicitly modelled in the empirical Euler equation by parameterising the shadow value of internal funds. With an explicitly parameterised shadow value, an augmented Euler equation can be estimated for the firms expected to face these financing constraints (e.g., Whited, 1992; Hubbard et al. 1995; Jaramillo et al. 1996). Assessment of the over-identifying restrictions in these estimations sheds light on the correctness of the implied nature of the financing constraints.

Not all is gold that glitters, though, and Euler equations also have a number of drawbacks. The most notable are the following (see also Gilchrist and Himmelberg, 1995). First, Euler equations may fail to detect financing constraints that are constant through time, as in such instances the decision to invest today versus postponing till the next period is not distorted by a change in the shadow value of internal funds. Second, in line with the critique on twostage estimators in general, Euler equations are sensitive to the exact specification and the selection of instruments.

14 Note that the formulation of the null does not test for the existence of a positive wedge between the cost of external verses internal funds. Rather, the interpretalion of $f_{t}=0$ in this regard is that $f_{t}$ need not be incurred when the financing constraint is nonbinding and hence the investment decision is made as if $f_{i}$ is equal to zero. 


\subsubsection{Reduced form investment equations}

A particular restriction that is shared by the Q-models as well as the Euler equations is that both require a specific characterisation of the adjustment cost function for empirical implementation. This, of course, may constitute a serious limiting assumption on the analysis as the exact adjustment cost technology may be difficult to capture in a simple functional form (also see footnote 4 ). The main advantage of using reduced form investment models is that one abstains from the need to explicitly model the adjustment cost technology altogether. Instead, the empirical implication of costly adjustment is taken as a starting point in the sense that it is assumed that adjustment takes time. Hence, in an empirical sense, partial adjustment is expected. For the remainder of this section a particular illustration of a reduced form investment equation is presented using an auto-regressive distributed lag (ADL) characterisation of the adjustment process. In the ADL model, the capital stock is a function of its own past (to reflect persistence due to adjustment costs) as well as present and past levels of the targeted capital stock (to reflect adjustment incentives):

$$
k_{t}=\sum_{s=1}^{L} k_{t-s}+\sum_{s=0}^{M} k_{t-s}^{*},
$$

where $L$ and $M$ capture the number of lags to be included for $k^{\left({ }^{*}\right)}$ (denoting the logarithm of the actual (optimal) capital stock). In order to implement this framework we need to define $L$ and $M$ as well as the optimal capital stock $k^{*}$.

The optimall capital stock is obtained from a simple maximisation problem. Consider a production function in which capital $\left(K_{t}\right)$ is the only factor to produce output $\left(Y_{l}\right)$ and output is a linear function of capital inputs:

$$
Y_{t}=F\left(K_{t}\right)=\alpha_{K} K_{t}
$$

In addition, we assume a sufficient degree of monopolistic competition to ensure a downward sloping demand function for output:

$$
p_{t}=Y_{t}^{-1}
$$

where $\eta^{D}>1$, to ensure a price elastic demand for output. The firm then maximises sales less rental costs of capital, subject to price elastic demand. The solution to this maximisation problem is the static optimal capital stock $K_{t}^{*}$, 
which in the partial adjustment setup may be interpreted as the long-run or desired capital stock: ${ }^{15}$

$$
K_{t}^{*}=Y_{t}\left(\frac{r_{t}}{p_{r}\left(1-y_{n^{D}}\right)}\right)^{-1} .
$$

This gives a log-linear representation for $k_{i}^{*}$, as shown in equation $(2.24)$, with $k^{*}=\ln K^{*}$ and $y=\ln Y$.

$$
k_{t}^{*}=y_{t}+\ln \left(1-y_{\eta^{D}}\right)-\ln \left(r_{p}\right)_{t}
$$

Regarding the adjustment process, the ADL characterisation is chosen with $L=M=1$ :

$$
k_{t}=\alpha_{1} k_{t-1}+\beta_{0} k_{t}^{*}+\beta_{1} k_{t-1}^{*}
$$

which has the convenient property that - under the long-run proportionality restriction $\left(\beta_{0}+\beta_{1 / 1-\alpha_{1}}\right)=1$ - it may collapse into an error correction model:

$$
\Delta k_{t}=-\beta_{1} \Delta k_{t}^{*}+\left(1-\alpha_{1}\right)\left(k_{t}^{*}-k_{t-1}\right)
$$

where $k=\ln K$ and $\Delta x_{t}=\ln X_{t}-\ln X_{t-1}$. Inserting expression (2.24) for the optimal capital stock into equation (2.26) gives the reduced form of a simple neoclassical investment decision:

$$
\begin{aligned}
& \Delta k_{t}=\left(1-\alpha_{1}\right) \ln \left(1-y_{\eta^{D}}\right)-\beta_{1} \Delta y_{t}+\left(1-\alpha_{1}\right)\left(y_{t}-k_{t-1}\right) \\
& +\beta_{1} \Delta \ln \left(\gamma_{p}\right)_{t}-\left(1-\alpha_{1}\right) \ln (\gamma / p)_{t} .
\end{aligned}
$$

The impact of financing constraints is then analysed similar to the Q-model. When financing constraints do not matter, equation (2.27) suffices to characterise investment. Financial variables - when added to the investment model - cannot increase the explanatory power of the model significantly. However, when the firm has to resort to costly external finance, the

15. Bond and Van Reenen (1999) derive a very similar first order condition for: capital from a more comprehensive specification of the production function (constant elasticity of substitution characterisation of production with labour as an additional factor of production). Hence the simplified representation of the production process does not lead to loss of generality. 
accumulation of internal funds plays a role in the investment decision in addition to profitability considerations. Hence financial variables - such as cash flow or the stock of liquid assets - would contribute meaningfully to the explanation of investment when added to the empirical equivalent of equation (2.27).

The main disadvantage of using reduced form models to characterise investment demand is that they may be particularly ill-suited for determining the structural determinants of capital demand. To illustrate this potential problem, suppose that the characterisation of the production or adjustment function is too simple, so that equation (2.27) does not fully capture the inputs in the investment decision. If that is the case, variables that are not a structural determinant of investment, yet are correlated with expected future profitability of the firm, appear as significant in the estimated investment function. In particular, when current profits are a leading indicator for future profits, current profits will have significant explanatory power in the empirical investment equation, even though financial factors may play no role in the structural investment decision.

Despite this drawback, the reduced form investment equation may still be useful in the analysis of financing constraints on investment and is in fact used in a variety of studies (e.g., Fazzari et al., 1988; Harris et al., 1994; Chirinko and Schaller, 1995; Lamont, 1997). The validity of reduced form models in this regard depends on the sufficient condition that the mismeasurement of investment demand - and hence the informational content of the financial variables - is the same for constrained and unconstrained firms alike. If this is the case, the differences in the impact of financial variables on the investment demand of constrained and unconstrained firms still reflect the presence of binding financial constraints. Building on the same intuition as in the empirical Q-model (equation (2.15)), financial variables should have a stronger impact on the investment decision of financially constrained firms relative to unconstrained firms.

\subsection{Methodological issues}

The three theoretical characterisations of investment all have their specific problems when they are implemented empirically. The previous section indicated that the Q-model and the reduced form models may be prone to biased cash flow sensitivities when investment fundamentals are mis-measured and that the Euler equation may be sensitive to specification and instrument selection. In this section the focus is on methodological, rather than empirical issues. In particular, we address the issues of endogenous regime selection and 
endogenous changes in available internal funds. Furthermore, we discuss the informational content of financing constraints and the extent to which empirical research designs merely demonstrate the extent to which the constraint is binding.

\subsubsection{Endogenous regime selection}

As was explained in section 2.2.1, the split sample analysis of the empirical $Q$ investment equation may yield patterns of sensitivity of investment to financial factors that are in line with the financing constraints explanation, but are in fact spurious and driven by the simultaneous endogeneity of regime selection and changes in internal funds. Endogenous regime selection in this regard refers to firms with unobserved positive shocks to investment opportunities self-selecting into the constrained regime, whereas endogenous changes in internal funds refers to a positive correlation between such shocks and for instance cash flow.

When regime selection is endogenous, yet changes in internal funds are not, firms faced with unobserved positive shocks to investment opportunities self-select into the constrained regime, although the impact of financial variables on their investment decision remains unbiased. Then, sensitivity of investment demand by constrained firms to financial variables suggests the relevance of binding financing constraints. Similarly, when changes in internal funds are endogenous, but regime selection is not, we expect the investment demand of both constrained and unconstrained firms to be sensitive to financial variables. However, the excess sensitivity of constrained firms" investment demand to financial factors still suggests the relevance of financing constraints. Hence, technically speaking, the sufficient condition for the differential sensitivity of investment to financial factors to indicate the presence of financing constraints is that either the regime selection criterium or changes in internal funds are orthogonal on the unobserved innovations in investment opportunities. We discuss the regime selection issue here and leave the issue of endogenous changes in internal funds to the next subsection.

In FHP88, firms are sorted according to contemporaneous retention practice, with high retention firms assigned to the constrained regime and low retention firms to the unconstrained regime. Endogenous regime selection is a possibility as firms with positive unobserved innovations in investment opportunities may simultaneously decide to invest more and retain a larger fraction of earnings. One way to remove the endogeneity in regime selection is to sort firms on the basis of pre-sample characteristics. For instance, conditioning on the dividend policy of the firm in the run-up to the period over which the estimation is conducted results in orthogonality of unobserved 
innovations to investment opportunities and the regime selection criterium. However, as financing constraints may change over time, the strategy likely includes unconstrained sample-years among sets of firms that were classified as constrained and vice versa. Moreover, the precision of the a priori classification is decreasing in the length of the estimation period as a switch between regimes becomes more likely over a longer period of time. Therefore, although endogenous regime selection is circumvented this way, it may come at the cost of a downward bias in the sensitivity of investment to changes in internal funds, where the bias increases with the length of the estimation period. A positive note is therefore that this regime selection strategy produces rather conservative estimates of the differential sensitivity of investment to changes in internal funds and may as such be interpreted as a lower bound to the true importance of financing constraints. ${ }^{17}$

Alternatively, a switching regression framework assigns observations on a period-by-period basis to the constrained and unconstrained regimes (e.g., Hu and Schiantarelli, 1998). In essence, the switching function assigns observations to either one of the constrained classes based on the behaviour of the firm, conditional on a set of characteristics that the researcher inserts in the switching function. Hence this framework explicitly takes into account that firms may switch from one regime to another over time. Furthermore, the sign and significance of the variables in the switching function can be used to assess those factors that contribute to the probability of being financially constrained. A particular feature of this approach is that it focusses exclusively on whether or not the financing constraint is binding, i.e. it does not measure differences in the cost of external finance between groups of firms. We return to this issue in section 2.3.4.

\subsubsection{Endogenous changes in internal funds}

When changes in internal funds are correlated with unobserved innovations in investment opportunities, the absolute sensitivity of investment to financial

16 For applications of this method see, for instance, Whited (1992), who characterises firms on the presence of a bond rating, Gilchrist and Himmelberg (1995), who split on dividend payout as well as bond and commercial paper ratings; Hubbard et al. (1995), who exploit dividend payout, and; Galeotti et al. (1994) using size.

17 Bond and Meghir (1994) attempt to reap the benefits of a priori regime selection without incurring this bias. Their strategy is to characterise the investment regime for each firm and each sample year separately. In particular, a firm is characterised as "constrained" when, at time $t$, it had paid out only a low fraction of eamings in $t-l$ and $t-2$. In this manner, the extrapolation problem is reduced and simultaneously the endogenous regime selection problem avoided. 
factors does not necessarily reflect binding financing constraints: Moreover, to the extent that regime selection is also possibly endogenous, differences in these sensitivities may be difficult to relate to financing constraints as well. For both of these reasons, it is important to assess the extent to which empirical findings in favour of financing constraints can be driven by the correlation between financial factors and unobserved innovations in investment opportunities.

There are basically two different ways to assess the effect on investment of exogenous changes in internal finance only. On the one hand, one may control for the informational content of changes in internal funds, i.e. extract that part that is correlated with innovations to investment opportunities. Subsequently, the sensitivity of investment to the pure liquidity content of changes in internal funds can be assessed. Gilchrist and Himmelberg (1995 and 1998) implement this strategy within a Q framework. Using information on observable fundamentals, the authors construct an expected value of marginal Q. Net worth changes are included in the set of observed fundamentals, so that even in the situation where a shock to net worth is correlated with shocks to investment opportunities, this effect is incorporated in the expected value of marginal Q. Therefore, the additional information contained in the cash flow variable that is added to the investment equation in conjunction with expected $Q$ relates only to its liquidity content. The general finding by Gilchrist and Himmelberg (1995) is that even after controlling for the informational content in cash flow, constrained firms exhibit excess sensitivity to internal finance. Thus innovations in cash flow orthogonal on innovations in investment opportunities contribute positively to investment, a finding that is in line with the working of financing constraints.

On the other hand, one may select particular instances where changes in internal funds are expected to be uncorrelated with innovations in investment opportunities. Put differently, the search is for a semi-natural experiment in which the changes in wealth are uncorrelated with the error term in the investment equation. Lamont (1997), for instance, investigates the investment decision of segments that belong to a conglomerate that contains also a segment in the oil industry. The focus is on the impact of the oil price decline of $1986-\mathrm{a}$ negative shock to oil segments' cash flow - on the investment decision of the non-oil segments. The findings of the analysis clearly indicate responsiveness of non-oil investment to this exogenous fall in corporate net worth. ${ }^{18}$

18 Earlier studies by Holtz-Eakin et al. (1994a, 1994b) investigate the impact of inheritances on entrepreneurial activity. Holtz-Eakin et al. (1994a) examine the impact on entrepreneurial survival of the receipt of an inheritance. The empirical results show a clear and significant positive impact of an inheritance on the probability that the entrepreneur remains in business. Holtz-Eakin et al. (1994b) find that the receipt of an inheritance 
The analyses that carefully control for the informational content of changes in net worth as well as the studies that examine the liquidity effect in semi-natural experiments, generally find similar net worth sensitivities obtained from the financing constraints analyses that do not control for the potential profit signalling effect of cash flow. Hence, we may cautiously conclude that this particular endogeneity problem does not generate the cash flow sensitivity patterns that are supportive of the theory of financing constraints.

\subsubsection{The informational content of financing constraints}

Many contributions in the area of financing constraints and investment relate the impact of internal funds on investment to informational problems in the capital markets. In particular, it is argued that informational asymmetries create a risk premium on debt and a lemon's premium on equity, raising the cost of acquiring external finance accordingly relative to using internal finance.

Fazzari et al. (1996), however, provide a formal definition of financing constraints that is considerably broader than that as "[c]onditions that raise the cost of external finance (debt or equity) above the opportunity cost of internal finance" (p. 4). This definition allows for a broader array of factors explaining financing constraints than information problems alone. Simple tax considerations, for instance, may be a sufficient condition for the preference of internal over external funds. In fact, the FHP88 theoretical model produces a wedge between internal and external funds even in the absence of information problems, provided that the tax rate on dividends exceeds that on capital gains. In addition, firms may also attempt to avoid the transaction costs associated with raising external funds and prefer internal over external finance for that reason. ${ }^{19}$ The definition of financing constraints therefore does not restrict them to result from information problems only and - as a corollary - finding that firms face finaneing constraints therefore does not automatically imply that these firms suffer from information problems in capital markets. Therefore it is evident that "[t] he research agenda [...] should include efforts to identify more

contributes positively and statistically significantly to the probability that the individual becomes an entrepreneur.

19 More importantly, to the extent that the main part of these transaction costs consists of a fixed charge, the cost per unit of external finance is also lower for larger firms. Hence this specific transaction cost argument can in principle even explain excess sensitivity of investment to cash flow for small firms. Oliner and Rudebusch (1992) explicitly distinguish between an asymmetric information and a transaction costs explanation for the observed patterns in investment-cash flow sensitivities. Their findings suggest that information problems contribute to the severity of financing constraints, whereas transaction costs do not seem to have a significant impact. 
carefully the nature of the information and agency problems that make external finance more expensive than internal finance" (Schiantarelli, 1996, p. 86). We discuss a possible handling of this issue in the next subsection.

\subsubsection{Binding constraints versus more costly external finance}

A related issue is that the sensitivity of investment to financial factors is often related directly to the cost of external relative to internal funds (we will refer to this wedge as 'premium' for the remainder of this chapter). We want to emphasise in this subsection that a firm may in fact face a larger premium that does not result in a stronger investment-cash flow sensitivity, because the financing constraint does not bind. Similarly, we expect that investment of firms with a low premium, but binding constraints is more sensitive to financial factors than the investment of firms with a large premium, but non-binding constraints. ${ }^{20}$

This argument is simply illustrated with the following thought experiment. Consider two sets of firms. One set operates in a growing, relatively new industry; the other in a mature industry. Assume that mature firms are particularly subject to incentive problems as outlined by Jensen (1986) in that they have a distinct ability to invest free cash flow in empire building projects. The mature firms' premiums reflect this incentive problem. Also assume that the young firms face excellent investment opportunities and therefore can be characterised by a relatively high investment demand. The young firms face a lemon's premium on external finance, because it has yet to be determined which young firms flourish and which falter. Lastly, assume that the incentive premium for mature firms outweighs the lemon's premium for young firms. Figure 2.2 shows that in this scenario the young firms will display the strongest investment-cash flow sensitivity, even though the mature firms face a higher premium. The crucial point is that, on average, the mature firms' financing

20 To illustrate this point more clearly, refer to Hubbard (1998), who states that "W7hen the incentive constraint binds, actual investment [...] increases with increases in net worth. [...] holding constont investment opportunities" (p. 197). However, "for a firm facing no information costs or with sufficient net worth (or internal funds) to finance its desired capital stock, [..] an increase in net worth independent of changes in imvesimem opportumities has no effect on imvesment" (p. 197). The dual message of this quote is not always fully appreciated. An insignificant investment-cash flow sensitivity is frequently interpreted as indicating a low or zero premium. However, Hubbard explicitly states that this is but one explanation and that such findings can also be explained by non-binding financing constraints. Hence it provides no information regarding the premium. Graphically, this argument follows directly from figure 2.1 , above: regardless of the premium, $f$, for firms with an investment demand that is low $\left(I_{L}\right)$ relative to internal funds $(W)$, changes in internal funds do not affect investment. 
constraints do not bind. The researcher, however, is inclined to interpret his findings as suggesting that small firms face a higher premium. In effect, then, the importance of the lemon's problem is over-stated because the research design did not control for the differing extent to which the financing constraints bind for young and mature firms. The empirical results derived from the above setup are thus heavily affected by the proportions of young and mature firms facing binding constraints, which may vary over time and across data sets. ${ }^{21}$

\section{Figure 2.2}

More costly external finance or binding constraints?

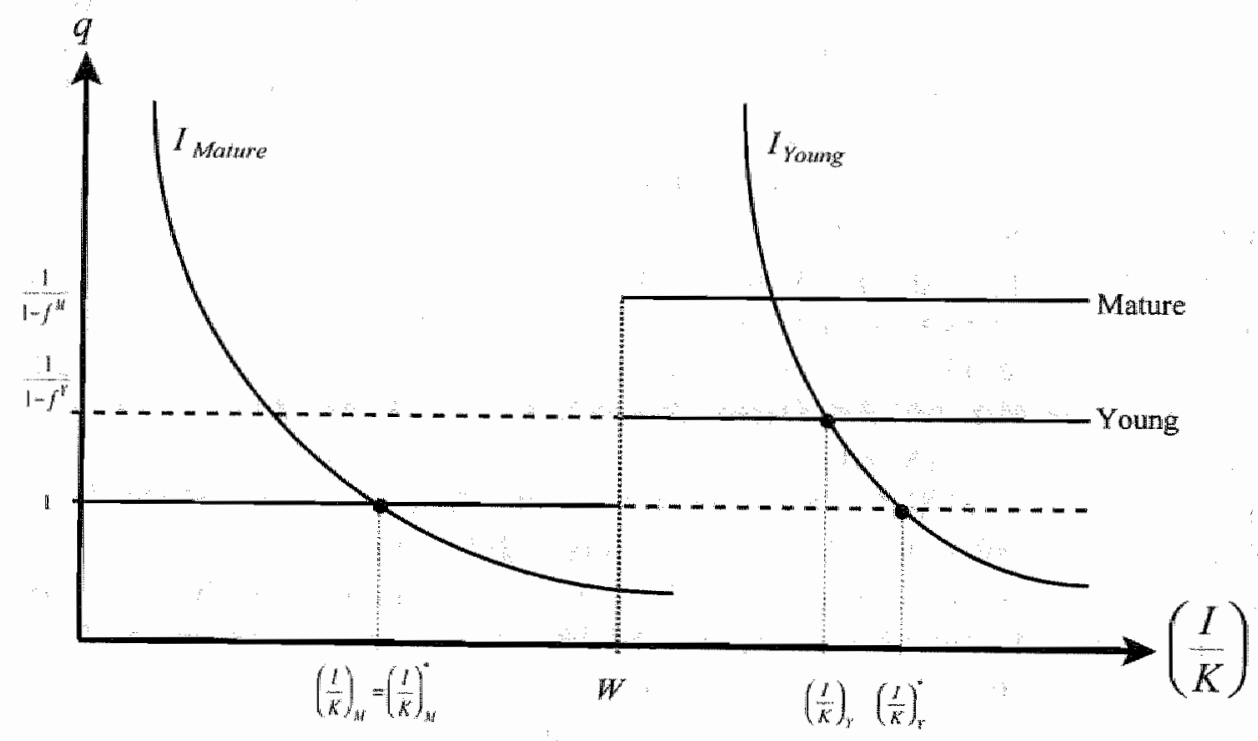

Note that this issue does not lead to incorrect interpretation regarding the incidence of financing constraints, i.e. young firms are the firms who bear the brunt of financing constraints. In fact, to the extent that the researcher is interested only in identifying those types of firms for which the incidence of financing constraints is highest, sorting on the probability that the financing

21 Maturity is obviously not the only splitting criterion that may suffer from the sketched problem. In this respect, it is useful to note the mixed evidence on the presence of financing constraints using size as a sample-splitting variable. For instance, small firms are usually somewhat more sensitive to cash flow in their inwestment decision (e.g., Gilchrist and Himmelberg, 1995; Harris et al., 1994; Jaramillo et al., 1996), but sometimes large firms are more sensitive (e.g., Hu and Schiantarelli, 1998) whilst in a number of studies size doesn't matter (e.g., Devereux and Sohiantarelli, 1990; Van Ees and Garretsen, 1994). 
constraint binds - disregarding differences in premiums - is valid. ${ }^{22}$ However, to the extent that the research aims to identify the types of firms that face the highest premium, this sorting of firms may lead to invalid inference and misleading conclusions.

\section{Figure 2.3}

Identifying differences in the cost of external finance

(A)

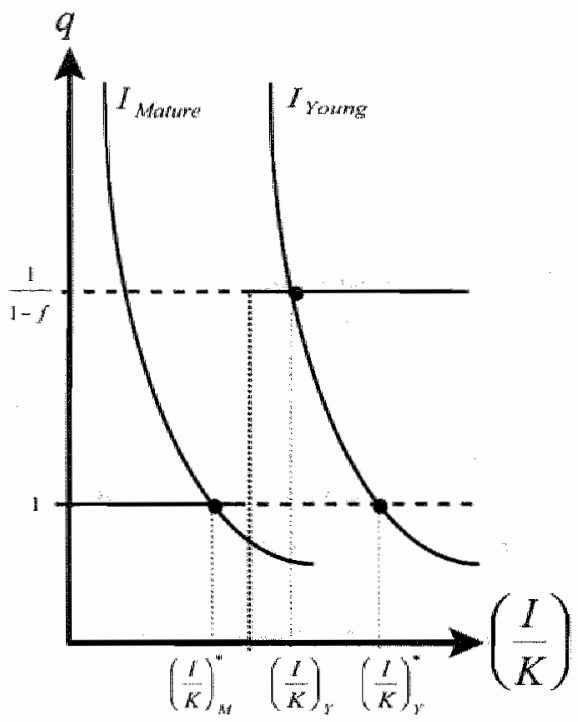

(B)

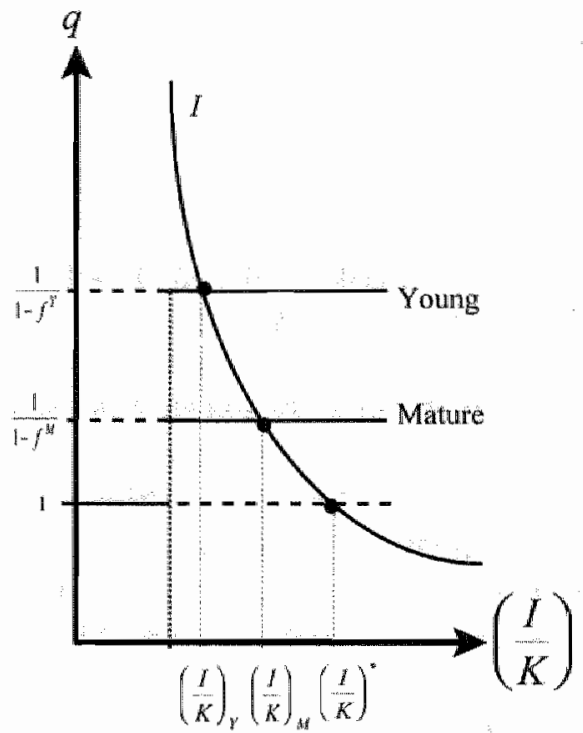

Controlling properly for the extent to which financing constraints bind is therefore important for the correct assessment of differences in premiums between different types of firms. We illustrate this claim using the example of young and mature firms once more in figure 2.3. Let us now assume in panel (A) of the figure that the premium is the same for young and mature firms alike, but investment opportunities are considerably better for young firms. In panel (B) we assume that investment opportunities do not differ much on average between young and mature firms, but the premium is highest for young firms.

${ }_{22} \mathrm{Hu}$ and Schiantarelli (1998) present a switching regression analysis that focusses exclusively on whether the financing constraint is binding rather than on its nature or the level of the premium. The interpretation of the switching function is precisely that it calculates the probability that a firm behaves according to the constrained characterisation of investment, i.e. the probability that its financing constraint, regardless of the premium, is binding. 
Empirically, the finding of excess sensitivity for young firms may now be due to either a larger proportion of young firms facing binding constraints (figure $2.3 \mathrm{~A}$ ) or a higher premium for young firms (figure $2.3 \mathrm{~B}$ ). The source of this excess sensitivity is unclear unless we compare young and old firms with binding constraints only. Selecting those firms for which we expect the constraint to bind and within this selection comparing young and mature firms results in an estimate of the difference in the premium. In the above setup, it means that we attempt to select those young and mature firms for which investment demand is high relative to internal funds so as to make sure that figure 2.3B best characterises our empirical analysis.

An important added advantage is that this strategy also allows for the correct identification of the role of informational problems in the financing constraint. If - among the firms for which we expect the constraint to bind - we compare firms for which we distinctly expect a larger degree of informational problems and firms for which we do not, a measure of the informational content of the financing constraint results. A relatively small number of studies employs this multivariate strategy ${ }^{23}$ For instance, Whited (1992) keeps the debt and coverage ratios constant and assesses the impact of a bond rating on the cash flow sensitivity of investment. The findings suggest that having a bond rating does indeed reduce the premium. Jaramillo et al. (1996) and Harris et al. (1994) control for the size of the firm and assess the impact of financial reform. Both studies conclude that the financial reform reduces the premium for small firms.

\subsection{Overview of empirical studies}

In this section, we take the theoretical and methodological considerations of the previous two sections to a body of empirical studies on financing constraints. This provides an indication of the extent to which the evidence is supportive of the notion of financing constraints in corporate investment decisions. The international empirical evidence is skewed towards US oriented studies with roughly half of those considered below employing US data sets. Though using data from one and the same country, these papers differ widely in terms of the specification of the investment equation, the selection of the sample splitting methodology as well as the use of proxies for the identification of financing constraints. Hence, focusing on US studies alone in section 2.4.1 allows us to relate empirical findings to methodological and theoretical choices without the

23. An important practical problem of employing multivariate sample splits is that the number of observations per category is reduced tremendously, so that the power of statistical tests decreases considerably. 
need to worry about for instance country-specific features in the financial system. The extent to which our observations from US evidence can be generalised to economies around the world is examined in section 2.4.2. Here findings based on US data sets are compared to those using data sets from fourteen other economies. These other economies may share the US marketbased orientation (UK), but they also include more bank-based systems in Europe (Germany, the Netherlands) and Asia (Japan, Korea), as well as transforming economies (Poland, Bulgaria).

\subsubsection{US evidence}

Table 2.1 summarises US oriented empirical research, covering nearly twentyfive sample years of firm-level analysis. The studies are summarised according to the following characteristics. Column 3 reports the criteria used to sort out those firms for which the investment decision is expected to be made subject to financing constraints. For studies using multiple, uni-variate splits, the criteria and results are summarised per split. Column 4 denotes the sample splitting methodology. Here "Split" stands for the separate estimation of the investment equation for the subsets of constrained and unconstrained firms. When clearly reported in the relevant analysis, it is also marked whether the sample was split using information obtained during the sample period (ex post) or on the basis of pre-sample information (ex ante). 'Interaction' denotes a split sample analysis through the use of interaction terms and 'Switching' indicates the use of a switching regression framework. The theoretical specification of the investment equation is given in column 5, where ' $Q$ ' denotes use of a $Q$-model of investment, ' $E$ ' the Euler equation approach, and ' $R$ ' a reduced form investment equation. Columns 6 and 7 mark whether financial variables (mostly cash flow) are important determinants for investment of the subsets of unconstrained (column 6) and constrained (column 7) firms. When financial variables are relevant to both unconstrained and constrained firms, but significantly more so for the latter type of firms, collumn 7 denotes this differential by 'Stronger'.

Three main features of the table deserve close attention. First of all, looking at the empirical effect of financial variables on investment for the subsets of unconstrained firms, it follows that most studies using an Euler equation specification find none. For studies employing Q-models or reduced form investment equations, however, the investment of unconstrained firms is significantly dependent on financial variables in a majority of instances. As discussed in section 2.2, a possible and plausible explanation points to mismeasured investment fundamentals in the latter characterisations of investment. We are thus unable to reject the hypothesis that financial variables for 
Table 2.1

US evidence on financing constraints and investment

\begin{tabular}{|c|c|c|c|}
\hline Study & Data dimensions & $\begin{array}{l}\text { Expect financing constraints } \\
\text { for the following sub-sample }\end{array}$ & $\begin{array}{l}\text { Splitting } \\
\text { methodology }\end{array}$ \\
\hline $\begin{array}{l}\text { Fazzari et al. } \\
(1988)\end{array}$ & $\begin{array}{l}422 \text { firms } \\
1970-1984\end{array}$ & low dividend payout & Split (ex post) \\
\hline $\begin{array}{l}\text { Hubbard and } \\
\text { Kashyap (1992) }\end{array}$ & $\begin{array}{l}\text { Agricultural sector } \\
\text { 1914-1987 }\end{array}$ & $\begin{array}{l}\text { periods of low net worth } \\
\text { bust periods }\end{array}$ & $\begin{array}{l}\text { Split } \\
\text { Split }\end{array}$ \\
\hline $\begin{array}{l}\text { Oliner and } \\
\text { Rudebusch (1992) }\end{array}$ & $\begin{array}{l}120 \text { firms } \\
1977-1983\end{array}$ & $\begin{array}{l}\text { young } \\
\text { OTC traded } \\
\text { high insider trading } \\
\text { low insider shareholdings } \\
\text { low shareholder concentration } \\
\text { low dividend payout }\end{array}$ & $\begin{array}{l}\text { Interaction } \\
\text { Interaction } \\
\text { Interaction } \\
\text { Interaction } \\
\text { Interaction } \\
\text { Interaction } \\
\end{array}$ \\
\hline Whited (1992) & $\begin{array}{l}325 \text { firms } \\
1975-1986\end{array}$ & $\begin{array}{l}\text { no bond rating } \\
\text { high debt ratio } \\
\text { low interest coverage }\end{array}$ & $\begin{array}{l}\text { Split (ex ante) } \\
\text { Split (ex ante) } \\
\text { Split (ex ante) } \\
\end{array}$ \\
\hline $\begin{array}{l}\text { Fazzari and } \\
\text { Petersen (1993) }\end{array}$ & $\begin{array}{l}422 \text { firms } \\
1970-1984 \\
\end{array}$ & low dividend payout & Split (ex post) \\
\hline $\begin{array}{l}\text { Carpenter et al. } \\
\text { (1994) }\end{array}$ & $\begin{array}{l}2033 \text { firms } \\
1981-1992\end{array}$ & $\begin{array}{l}\text { small size } \\
\text { small size \& 1981-1984 } \\
\text { small size \& 1984-1988 } \\
\text { small size \& 1988-1992 } \\
\text { no bond rating } \\
\text { no bond rating \& 1981-1984 } \\
\text { no bond rating \& 1984-1988 } \\
\text { no bond rating \& 1988-1992 }\end{array}$ & $\begin{array}{l}\text { Split } \\
\text { Split } \\
\text { Split } \\
\text { Split } \\
\text { Split } \\
\text { Split } \\
\text { Split } \\
\text { Split } \\
\end{array}$ \\
\hline $\begin{array}{l}\text { Himmelberg and } \\
\text { Petersen (1994) }\end{array}$ & $\begin{array}{l}179 \text { firms } \\
1983-1987 \\
\end{array}$ & small firms in high-tech sector & - \\
\hline Vogt (1994) & $\begin{array}{l}312 \text { firms } \\
1972-1986 \\
\end{array}$ & low dividend payout & Split (ex post) \\
\hline $\begin{array}{l}\text { Calomiris and } \\
\text { Hubbard (1995) }\end{array}$ & $\begin{array}{l}273 \text { firms } \\
1933-1938 \\
\end{array}$ & high surtax margin & Interaction \\
\hline $\begin{array}{l}\text { Gilchrist and } \\
\text { Himmelberg } \\
\text { (1995) }\end{array}$ & $\begin{array}{l}428 \text { firms } \\
1979-1989\end{array}$ & $\begin{array}{l}\text { small size } \\
\text { low dividend payout } \\
\text { no commercial paper rating } \\
\text { no bond rating }\end{array}$ & $\begin{array}{l}\text { Split (ex ante) } \\
\text { Split (ex ante) } \\
\text { Split (ex ante) } \\
\text { Split (ex ante) } \\
\end{array}$ \\
\hline $\begin{array}{l}\text { Hubbard et all. } \\
(1995)\end{array}$ & $\begin{array}{l}428 \text { firms } \\
1976-1987 \\
\end{array}$ & $\begin{array}{l}\text { low dividend payout } \\
\text { young }\end{array}$ & $\begin{array}{l}\text { Split (ex ante) } \\
\text { Split }\end{array}$ \\
\hline
\end{tabular}




\begin{tabular}{|c|c|c|c|}
\hline $\begin{array}{l}\text { Investment } \\
\text { model }\end{array}$ & $\begin{array}{l}\text { Financing constraints in } \\
\text { unconstrained sub-sarmple? }\end{array}$ & $\begin{array}{l}\text { Financing constraints in } \\
\text { constrained sub-sample? }\end{array}$ & Study \\
\hline$Q / R$ & Yes & Stronger & $\begin{array}{l}\text { Fazzani et al. } \\
(1988)\end{array}$ \\
\hline $\mathrm{E}$ & $\mathrm{No}$ & Yes & Hubbard and \\
\hline$E$ & $\mathrm{No}$ & Yes & Kashyap (1992) \\
\hline $\mathrm{Q} / \mathrm{R}$ & Yes & Stronger & Oliner and \\
\hline$Q / R$ & Yes & Stronger & Rudebusch (1992) \\
\hline$Q / R$ & No & Yes & \\
\hline$Q / R$ & Yes & Yes & \\
\hline$Q / R$ & Yes & Yes & \\
\hline $\mathrm{Q} / \mathrm{R}$ & Yes & Stronger & \\
\hline $\mathrm{E}$ & Yes & Stronger & Whited (1992) \\
\hline $\mathrm{E}$ & No & Yes & \\
\hline $\mathrm{E}$ & No & $Y \mathrm{es}$ & \\
\hline $\mathrm{Q} / \mathrm{R}$ & Yes & Stronger & $\begin{array}{l}\text { Fazzari and } \\
\text { Petersen (1993) }\end{array}$ \\
\hline $\mathrm{R}$ & Yes & Stronger & Carpenter et al. \\
\hline $\mathrm{R}$ & Yes & Yes & $(1994)$ \\
\hline $\mathrm{R}$ & Yes & Stronger & \\
\hline $\mathrm{R}$ & No & Yes & \\
\hline $\mathrm{R}$ & Yes & Stronger & \\
\hline $\mathrm{R}$ & Yes & Yes & \\
\hline $\mathrm{R}$ & Yes & Yes & \\
\hline $\mathrm{R}$ & No & $\mathrm{Yes}$ & \\
\hline $\mathrm{Q} / \mathrm{R}$ & - & Yes & $\begin{array}{l}\text { Himmelberg and } \\
\text { Petersen (1994) }\end{array}$ \\
\hline $\mathrm{Q} / \mathrm{R}$ & Yes & Stronger & $\operatorname{Vogt}(1994)$ \\
\hline$Q$ & No & Yes & $\begin{array}{l}\text { Calomiriss and } \\
\text { Hubbard (1995) }\end{array}$ \\
\hline $\mathrm{Q}$ & No & Yes & Gilchrist and \\
\hline$Q$ & Yes & Stronger & Himmelberg (1995) \\
\hline$Q$ & No & Yes & \\
\hline$Q$ & No & Yes & \\
\hline$E$ & No & Yes & Hubbard et al. \\
\hline$E$ & No & Yes & $(1995)$ \\
\hline
\end{tabular}


Table 2.1

US evidence on financing constraints and investment (continued)

\begin{tabular}{|l|l|l|l|}
\hline Study & Data dimensions & $\begin{array}{l}\text { Expect financing constraints } \\
\text { for the following sub-sample }\end{array}$ & $\begin{array}{l}\text { Splitting } \\
\text { methodology }\end{array}$ \\
\hline Elston (1996) & $\begin{array}{l}220 \text { firms } \\
1975-1988\end{array}$ & $\begin{array}{l}\text { low dividend payout and } \\
\text { small size }\end{array}$ & Split (ex post) \\
\hline $\begin{array}{l}\text { Hsiao and } \\
\text { Tahmiscioglu } \\
\text { (1997) }\end{array}$ & $\begin{array}{l}561 \text { firms } \\
1971-1992\end{array}$ & high capital intensity & Split (ex post) \\
\hline Lamont (1997) & $\begin{array}{l}40 \text { non-oil } \\
\text { segments } \\
1985-1987\end{array}$ & segment in oil & Split (ex ante) \\
\hline $\begin{array}{llll}\text { Gilchrist and } \\
\text { Himmelberg (1998) }\end{array}$ & $\begin{array}{l}1980-1993 \\
\text { no firm-years }\end{array}$ & $\begin{array}{l}\text { no bond rating } \\
\text { low dividend payout } \\
\text { small size }\end{array}$ & $\begin{array}{l}\text { Split (ex ante) } \\
\text { Split (ex post) } \\
\text { Split (ex post) }\end{array}$ \\
\hline Hadlock (1998) & $\begin{array}{l}435 \text { firms } \\
1973-1976\end{array}$ & $\begin{array}{l}\text { low insider shareholdings } \\
\text { Split }\end{array}$ & high debt ratio \\
\hline $\begin{array}{l}\text { Hu and } \\
\text { Schiantarelli (1998) }\end{array}$ & $\begin{array}{l}584 \text { firms } \\
1978-1987\end{array}$ & $\begin{array}{l}\text { low interest coverage } \\
\text { low liquid assets ratio } \\
\text { large size }\end{array}$ & Switching \\
\hline
\end{tabular}

unconstrained firms are correlated with unobserved innovations to investment opportunities in this case. ${ }^{24}$

Mis-measurement of investment fundamentals need not affect the differential sensitivity of investment to financial variables for constrained and unconstrained firms. The sufficient condition for this is that the mismeasurement is not systematic in the sense that financial variables contain more information on investment profitability for constrained firms. If this condition is violated, mis-measurement of investment fundamentals may actually drive the excess sensitivity results. In terms of table 2.1 , such violation would lead us to expect that studies using Q-models and reduced form investment equations find the expected cash flow patterns more often than studies using the Euler equation

24 Note that Gilchrist and Himmelberg (1995, 1998) use Q models, but control for the informational content of cash flow. The remaining pure liquidity content of cash flow has insignificant explanatory power in the investment decision of the unconstrained firms. 


\begin{tabular}{|c|c|c|c|}
\hline $\begin{array}{l}\text { Investment } \\
\text { equation }\end{array}$ & $\begin{array}{l}\text { Financing constraints in } \\
\text { unconstrained sub-sample? }\end{array}$ & $\begin{array}{l}\text { Financing constraints in } \\
\text { constrained sub-sample? }\end{array}$ & Study \\
\hline$Q$ & Yes & No & Elston (1996) \\
\hline$Q / R$ & Yes & Stronger & $\begin{array}{l}\text { Hsiao and } \\
\text { Tahmiscioglu } \\
\text { (1997) }\end{array}$ \\
\hline $\mathrm{R}$ & Yes & Stronger & Lamont (1997) \\
\hline $\begin{array}{l}\mathrm{Q} \\
\mathrm{Q} \\
\mathrm{Q}\end{array}$ & $\begin{array}{l}\text { No } \\
\text { Yes } \\
\text { Yes } \\
\end{array}$ & $\begin{array}{l}\text { Yes } \\
\text { Stronger } \\
\text { Stronger }\end{array}$ & $\begin{array}{l}\text { Gilchrist and } \\
\text { Himmelberg (1998) }\end{array}$ \\
\hline$Q$ & No & Yes & Fadlock (1998) \\
\hline$Q$ & Yes & Stronger & $\begin{array}{l}\text { Hu and } \\
\text { Schiantarelli (1998) }\end{array}$ \\
\hline
\end{tabular}

approach. ${ }^{25}$ The second main feature of table 2.1 is therefore that we do not observe such a pattern. For studies using $Q$ or reduced form investment functions, most but not all find a difference in the sensitivity of investment to financial variables between constrained and unconstrained firms. All studies applying an Euler equation methodology, however, report results that are in line with the financing constraints hypothesis.

The third main feature is that a low dividend payout rate and the absence of a bond or commercial paper rating are both very consistently associated with excess sensitivity of investment to financial factors. As indicated before, the corporate dividend policy may relate to innovations in investment opportunities that are unobservable to the researcher (see sections 2.2.1 and 2.3.1). Hence, the association of the dividend payout rate to excess sensitivity most likely demonstrates that when financing constraints are binding, finance and

25 This results from the argument that the latter is not liable to the outlined mismeasurement problem and therefore is not prone to imposing the expected pattern of investment sensitivity to financial variables. Also see section 2.2. 


\section{Table 2.2}

International evidence on financing constraints and investment

\begin{tabular}{|c|c|c|c|}
\hline Study & Country & Data dimensions & $\begin{array}{l}\text { Expect financing constraints } \\
\text { for the following sub-sample }\end{array}$ \\
\hline Elston (1998) & Germany & $\begin{array}{l}139 \text { firms } \\
1698-1984\end{array}$ & $\begin{array}{l}\text { boom period \& independent } \\
\text { bust period \& independent }\end{array}$ \\
\hline $\begin{array}{l}\text { Weigand and } \\
\text { Audretsch (1999) }\end{array}$ & Germany & $\begin{array}{l}361 \text { firms } \\
1991-1996\end{array}$ & $\begin{array}{l}\text { in high-tech sector } \\
\text { small size } \\
\text { manager-controlled } \\
\text { all of the above }\end{array}$ \\
\hline $\begin{array}{l}\text { Audretsch and } \\
\text { Elston (2002) }\end{array}$ & Germany & $\begin{array}{l}100 \text { firms } \\
1970-1986\end{array}$ & small size \\
\hline $\begin{array}{l}\text { Devereux and } \\
\text { Schiantarelli } \\
(1990)\end{array}$ & UK & $\begin{array}{l}720 \text { firms } \\
1972-1986\end{array}$ & $\begin{array}{l}\text { small size } \\
\text { in declining sector } \\
\text { young }\end{array}$ \\
\hline $\begin{array}{l}\text { Bond and Meghir } \\
\text { (1994) }\end{array}$ & UK & $\begin{array}{l}626 \text { firms } \\
1974-1986\end{array}$ & $\begin{array}{l}\text { low dividend payout \& no } \\
\text { share issues }\end{array}$ \\
\hline $\begin{array}{l}\text { Scaramozzino } \\
(1997)\end{array}$ & UK & $\begin{array}{l}445 \text { firms } \\
1972-1986\end{array}$ & $\begin{array}{l}\text { high investment rate } \\
\text { low dividend payout } \\
\text { all of the above }\end{array}$ \\
\hline Schaller (1993) & Canada & $\begin{array}{l}212 \text { firms } \\
1973-1986\end{array}$ & $\begin{array}{l}\text { young } \\
\text { dispersed ownership } \\
\text { manufacturing } \\
\text { independent } \\
\end{array}$ \\
\hline $\begin{array}{l}\text { Chirinko and } \\
\text { Schaller (1995) }\end{array}$ & Canada & $\begin{array}{l}212 \text { firms } \\
1973-1986\end{array}$ & $\begin{array}{l}\text { young } \\
\text { dispersed ownership } \\
\text { manufacturing } \\
\text { independent }\end{array}$ \\
\hline \multirow[t]{2}{*}{$\begin{array}{l}\text { Galeotti et al. } \\
\text { (1994) }\end{array}$} & Italy & $\begin{array}{l}3039 \text { firms } \\
1983-1987 \\
\end{array}$ & small size \\
\hline & Italy & $\begin{array}{l}43 \text { firms } \\
1976-1987\end{array}$ & small size \\
\hline $\begin{array}{l}\text { Schiantarelli and } \\
\text { Sembenelli }(2000)\end{array}$ & Italy & $\begin{array}{l}1229 \text { firms } \\
1977-1990 \\
\end{array}$ & independent national firms \\
\hline
\end{tabular}




\begin{tabular}{|c|c|c|c|c|}
\hline $\begin{array}{l}\text { Splitting } \\
\text { methodology }\end{array}$ & $\begin{array}{l}\text { Investment } \\
\text { equation }\end{array}$ & $\begin{array}{l}\text { Financing } \\
\text { constraints in } \\
\text { unconstrained } \\
\text { sub-sample? }\end{array}$ & $\begin{array}{l}\text { Financing } \\
\text { constraints in } \\
\text { constrained } \\
\text { sub-sample? }\end{array}$ & Study \\
\hline $\begin{array}{l}\text { Split (ex post) } \\
\text { Split (ex post) }\end{array}$ & $\begin{array}{l}Q / R \\
Q / R\end{array}$ & $\begin{array}{l}\text { No } \\
\text { No }\end{array}$ & $\begin{array}{l}\text { No } \\
\text { Yes }\end{array}$ & Elston (1998) \\
\hline $\begin{array}{l}\text { Interaction } \\
\text { Interaction } \\
\text { Interaction } \\
\text { Interaction }\end{array}$ & $\begin{array}{l}\mathrm{R} \\
\mathrm{R} \\
\mathrm{R} \\
\mathrm{R}\end{array}$ & $\begin{array}{l}\text { Yes } \\
\text { Yes } \\
\text { Yes } \\
\text { Stronger }\end{array}$ & $\begin{array}{l}\text { Yes } \\
\text { Stronger } \\
\text { Yes } \\
\text { Yes }\end{array}$ & $\begin{array}{l}\text { Weigand and } \\
\text { Audretsch (1999) }\end{array}$ \\
\hline Split & $\mathrm{Q} / \mathrm{R}$ & No & $\begin{array}{l}\text { No (Yes for } \\
\text { medium) }\end{array}$ & $\begin{array}{l}\text { Audretsch and } \\
\text { Elston }(2002)\end{array}$ \\
\hline $\begin{array}{l}\text { Split (ex post) } \\
\text { Split (ex post) } \\
\text { Split }\end{array}$ & $\begin{array}{l}Q \\
Q \\
Q\end{array}$ & $\begin{array}{l}\text { Yes } \\
\text { Stronger } \\
\text { Yes }\end{array}$ & $\begin{array}{l}\text { Yes } \\
\text { Yes } \\
\text { Yes }\end{array}$ & $\begin{array}{l}\text { Devereux and } \\
\text { Schiantarelli } \\
(1990)\end{array}$ \\
\hline Interaction & $\mathrm{E}$ & Yes & Stronger & $\begin{array}{l}\text { Bond and Meghir } \\
\text { (1994) }\end{array}$ \\
\hline $\begin{array}{l}\text { Split (ex ante) } \\
\text { Split (ex ante) } \\
\text { Split (ex ante) }\end{array}$ & $\begin{array}{l}Q \\
Q \\
Q\end{array}$ & $\begin{array}{l}\text { No } \\
\text { Yes } \\
\text { No }\end{array}$ & $\begin{array}{l}\text { Yes } \\
\text { Yes } \\
\text { Yes }\end{array}$ & $\begin{array}{l}\text { Scaramozzino } \\
\text { (1997) }\end{array}$ \\
\hline $\begin{array}{l}\text { Split } \\
\text { Split (ex post) } \\
\text { Split } \\
\text { Split (ex post) } \\
\end{array}$ & $\begin{array}{l}Q \\
Q \\
Q \\
Q\end{array}$ & $\begin{array}{l}\text { Yes } \\
\text { Yes } \\
\text { Stronger } \\
\text { Yes } \\
\end{array}$ & $\begin{array}{l}\text { Stronger } \\
\text { Stronger } \\
\text { Yes } \\
\text { Stronger } \\
\end{array}$ & Schaller (1993) \\
\hline $\begin{array}{l}\text { Split } \\
\text { Split (ex post) } \\
\text { Split } \\
\text { Split (ex post) }\end{array}$ & $\begin{array}{l}\mathrm{R} \\
\mathrm{R} \\
\mathrm{R} \\
\mathrm{R}\end{array}$ & $\begin{array}{l}\text { Yes } \\
\text { Yes } \\
\text { Stronger } \\
\text { Yes }\end{array}$ & $\begin{array}{l}\text { Yes } \\
\text { Stronger } \\
\text { Yes } \\
\text { Stranger }\end{array}$ & $\begin{array}{l}\text { Chirinko and } \\
\text { Schaller (1995) }\end{array}$ \\
\hline Split (ex ante) & $\mathrm{R}$ & Yes & Stronger & $\begin{array}{l}\text { Galeoth et ail. } \\
\text { (1994) }\end{array}$ \\
\hline Split (ex ante) & $\mathrm{Q} / \mathrm{E}$ & No & Yes & \\
\hline Split (ex post) & $\mathrm{R}$ & $\mathrm{No}$ & Yes & $\begin{array}{l}\text { Schiantarelli and } \\
\text { Sembenelli }(2000)\end{array}$ \\
\hline
\end{tabular}


Table 2.2

International evidence on financing constraints and investment (continued)

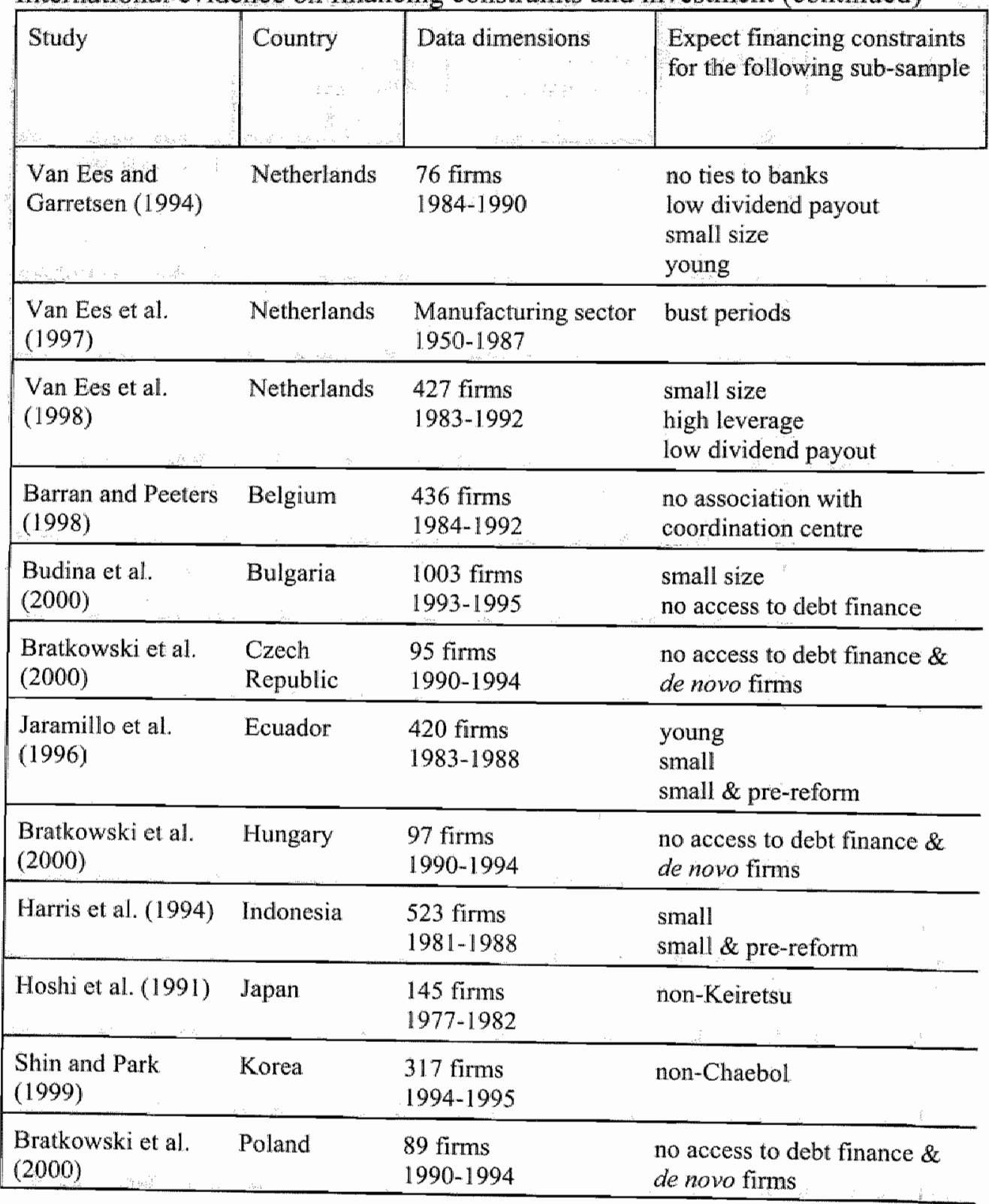




\begin{tabular}{|c|c|c|c|c|}
\hline $\begin{array}{l}\text { Splitting } \\
\text { methodology }\end{array}$ & $\begin{array}{l}\text { Investment } \\
\text { equation }\end{array}$ & $\begin{array}{l}\text { Financing } \\
\text { constraints in } \\
\text { unconstrained } \\
\text { sub-sample? }\end{array}$ & $\begin{array}{l}\text { Financing } \\
\text { constraints in } \\
\text { constrained } \\
\text { sub-sample? }\end{array}$ & Study \\
\hline $\begin{array}{l}\text { Split (ex post) } \\
\text { Split (ex post) } \\
\text { Split (ex post) } \\
\text { Split }\end{array}$ & $\begin{array}{l}Q \\
Q \\
Q \\
Q\end{array}$ & $\begin{array}{l}\text { No } \\
\text { Yes } \\
\text { Yes } \\
\text { Yes } \\
\end{array}$ & $\begin{array}{l}\text { Yes } \\
\text { Yes } \\
\text { Yes } \\
\text { Yes }\end{array}$ & $\begin{array}{l}\text { Van Ees and } \\
\text { Garretsen (1994) }\end{array}$ \\
\hline Split & $\mathrm{R}$ & Yes & Stronger & $\begin{array}{l}\text { Van Ees et al. } \\
(1997)\end{array}$ \\
\hline $\begin{array}{l}\text { Split } \\
\text { Split } \\
\text { Split }\end{array}$ & $\begin{array}{l}E \\
E \\
E\end{array}$ & $\begin{array}{l}- \\
- \\
-\end{array}$ & $\begin{array}{l}\text { No } \\
\text { Yes } \\
\text { Yes }\end{array}$ & $\begin{array}{l}\text { Van Ees et al. } \\
(1998)\end{array}$ \\
\hline Split (ex post) & $\mathrm{E}$ & Yes & Stronger & $\begin{array}{l}\text { Barran and Peeters } \\
(1998)\end{array}$ \\
\hline $\begin{array}{l}\text { Split (ex ante) } \\
\text { Split (ex ante) }\end{array}$ & $\begin{array}{l}\mathrm{R} \\
\mathrm{R}\end{array}$ & $\begin{array}{l}\text { No } \\
\text { No }\end{array}$ & $\begin{array}{l}\text { Yes } \\
\text { Yes }\end{array}$ & $\begin{array}{l}\text { Budina et al. } \\
(2000)\end{array}$ \\
\hline Split (ex post) & $\mathrm{R}$ & Yes & Stronger & $\begin{array}{l}\text { Bratkowski et al. } \\
(2000)\end{array}$ \\
\hline $\begin{array}{l}\text { Interaction } \\
\text { Interaction } \\
\text { Interaction }\end{array}$ & $\begin{array}{l}\mathrm{E} \\
\mathrm{E} \\
\mathrm{E}\end{array}$ & $\begin{array}{l}\text { No } \\
\text { No } \\
\text { Yes }\end{array}$ & $\begin{array}{l}\text { Yes } \\
\text { Yes } \\
\text { Yes }\end{array}$ & $\begin{array}{l}\text { Jaramillo et al. } \\
(1996)\end{array}$ \\
\hline Split (ex post) & $\mathrm{R}$ & Yes & Stronger & $\begin{array}{l}\text { Bratkowski et al. } \\
(2000)\end{array}$ \\
\hline $\begin{array}{l}\text { Interaction } \\
\text { Interaction }\end{array}$ & $\begin{array}{l}\mathrm{R} \\
\mathrm{R}\end{array}$ & $\begin{array}{l}\text { No } \\
\text { Yes }\end{array}$ & $\begin{array}{l}\text { Yes } \\
\text { Stronger }\end{array}$ & Harris et al. ( $₫ 994)$ \\
\hline Split & $Q$ & Yes & Stronger & Hoslui et al. (1991) \\
\hline Split & $Q$ & No & Yes & $\begin{array}{l}\text { Shin and Park } \\
(1999)\end{array}$ \\
\hline Split (ex post) & $\mathrm{R}$ & Yes & Stronger & $\begin{array}{l}\text { Bratkowski et al. } \\
(2000)\end{array}$ \\
\hline
\end{tabular}


investment are non-separable decisions. At the same time it is unclear what the results tell us regarding the premium for low and high dividend payout firms. ${ }^{26}$ The presence or absence of a credit rating, however, arguably exhibits little or no relationship to the probability that the financing constraint binds, especially over longer periods of time. Hence, sorting on the presence or absence of a rating gives a consistent - though inefficient - test on the difference in premiums between rated and non-rated firms. In that sense, the evidence in table 2.1 strongly supports the hypothesis that non-rated firms face higher premiums. ${ }^{27}$

\subsubsection{International evidence}

An overview of a selection of empirical studies on financing constraints in fourteen non-US economies is presented in table 2.2. The studies are summarised according to the same criteria as in table 2.1. Overall, the international evidence reflects our earlier observation that investment of constrained firms is more sensitive to financial factors than investment of unconstrained firms.

There are, however, some exceptions to this general finding. Most notably, there is mixed evidence at best regarding the relevance of financing constraints in both Germany and the UK. For Germany, Elston (1998) finds that independent firms in times of an economic downturn rely more heavily on internal finance than firms affiliated with banks. ${ }^{28}$ Weigand and Audretsch (1999), however, find that both ownership structure and informational sensitivity of activities have no impact on the dependency of investment decisions on financial factors. They do find that small firms appear to face stricter financing constraints, but this result is reversed in Audretsch and Elston $(2002){ }^{29}$ For the UK, Devereux and Schiantarelli (1990) find that - subject to afore-mentioned objections - small and young firms" investment displays no

26 Selecting low dividend payout firms is likely to sort out the firms for which the financing constraints - regardless of the premium - are binding. Also see section 2.3.4.

27 To the extent that on average, size is also unrelated to irnovations in investment opportunities the mixed evidence on this sorting criterum in table 2.1 suggests that there is little undication that small firms face higher premiums than large firms.

28. Edwards and Fisher (1994), Elston and Horst (1995), and Elston (1996) support the conclusion that banks play an important role in the German financial system in alleviating finamcing constraints.

29 This mixed evidence based on size as sample splitting variable is in line with previous discussions and applies more broadly to the international evidence presented in table 2.2 . 
excess sensitivity to financial variables. Also, firms in declining sectors display a lower sensitivity of investment to financial factors than firms in growing sectors. The latter finding may be due to the fact that firms in declining sectors - although they face higher premiums - have a lower probability of actually facing binding constraints. Firms in a growing sector, in contrast, may have a relatively high investment demand, resulting in a larger probability of facing binding constraints. Note that there is support for this conjecture in Scaramozzino's (1997) finding that firms that simultaneous have high investment demand and retain a large fraction of earnings display a strong sensitivity of investment to financial factors.

Furthermore, note that in comparison with table 2.1, studies employing the dividend payout rate to sort out constrained and unconstrained firms are relatively scarce. Studies using bond or commercial paper ratings to this end are even absent altogether. This stresses the unrivalled market-based US financial system with its important role for direct finance through stock and bond markets. In this regard, it is useful to note the similarity between the UK and US financial systems. Sample splits on dividend payout behaviour conducted by Bond and Meghir (1994) and Scaramozzino (1997) on UK data sets produce results similar to those obtained in US studies. In contrast, when the dividend payout rate as a sorting device is applied to a data set for a more bank-based system such as the Netherlands, it fails to provide clear evidence for the conjecture that low payout firms display excess sensitivity of investment to financial factors (contrast Van Ees and Garretsen (1994) and Van Ees et al. (1998)).

The difference between the arm's length US capital markets and the more intermediation-based financial systems of continental Europe and Japan in particular is visible in the success of firm relationships with banks in association with investment-cash flow sensitivities. For firms with close ties to banks, the investment decision is driven to a considerably lesser extent by financial factors than for independent firms (Elston, 1998; Van Ees and Garretsen, 1994). Similarly, for firms organised in an industrial group (Schaller, 1993; Chirinko and Schaller, 1995; Hoshi et al., 1991; Shin and Park, 1999), or around a coordination centre (Barran and Peeters, 1998), the results are unanimous in the sense that investment of independent firms is more importantly driven by financial factors. Comparable US studies are hard to come by, possibly because of the strong dislike of collusive behaviour by US competition authorities as well as the strict separation of firms and banks which precludes firms from depending to any meaningful extent on industrial groups or banks.

Overall, we document a broad literature that reports an excessive sensitivity of investment to financial variables for subsets of firms that are considered to face financing constraints. The empirical evidence is supportive 
of the joint hypothesis that a) we can discriminate constrained from unconstrained firms and $b$ ) the investment to cash flow sensitivity is a useful measure of financing constraints. We elaborate on this literature in chapters 3 and 4 . In chapter 3 , we consider a firm constrained when it faces high expected liquidation costs and subsequently analyse whether its investment is excessively sensitive to financial variables. In chapter 4 , we examine to what extent a constrained firm optimally reallocates internal funds between its segments.

\subsection{Do cash flow sensitivities indicate financing constraints?}

Although the investment-to-finance sensitivity patterns can be considered an empirical regularity, there is by now a growing discomfort with the proposed reading that these patterns indicate binding financing constraints. Points of concern relate to the lack of a thorough theoretical foundation, the ad hoc implementation of empirical tests, and the theoretical ambiguity of some of the criteria used to identify constrained firms. ${ }^{30}$ Important theoretical and empirical support for this concern is provided by Kaplan and Zingales (1997), hereinafter KZ97, who examine the subset of firms characterised by FHP88 as being financially constrained. Their empirical finding is that among these firms, the investment-to-finance sensitivity is not a monotonically increasing function in financing constraints. The important theoretical contribution of KZ97 is that their model displays the assumptions required to obtain this monotonic relationship. First, we analyse the KZ97 analysis more closely in section 2.5.1. Then, because they relate importantly to the research in the second part of this thesis, we discuss the most prominent research questions raised by the KZ97 contribution in section 2.5.2.

\subsubsection{The Kaplan and Zingales (1997) critique}

Kaplan and Zingales (1997) launch an attack on the entrenched research on investment and financing constraints with an in-depth investigation of the subset of 49 firms characterised by FHP8 8 as financially constrained. These firms display a strong sensitivity of investment to cash flow and FHP88

30 The uncertainty regarding cause and effect is critically formulated by Kaplan and Zingales (1997): "Firms with a lower-than-average leverage are sometimes interpreted, a prion, as relatively unconstrained firms [...] because they retain a large debt capacity and can obtain external funds very easily. In other papers, firms with lower-than-average leverage are considered to be relatively constrained [...] because they are assumed to maintain low leverage because the costs of being financially constrained or distressed would be extremely high" (p. 211). 
associate this with the presence of financing constraints. KZ97 classify these firms into likely, possibly, and not financially constrained using direct observation of anmual reports and managements" statements regarding liquidity and the ability to finance additional investment in every individual sample year. Firms are therefore classified on an annual basis and may switch between these classes over time.

Two major findings from the KZ97 analysis cast some doubt on the usefulness of investment-cash flow sensitivities in signalling financing constraints. First, KZ97 report that, based on the information in annual reports and managements' statements, only $15 \%$ of the observations can be regarded as likely constrained. In the vast majority of sample years, firms indicate that they could have expanded investment considerably, should they have chosen to do so. In fact, nearly half of the firms indicate that they could have done so in every individual year of the sample (1970-1984). ${ }^{31}$ The second finding concerns the investment-cash flow sensitivity of these subsets of firms. KZ97 find no indication that the cash flow sensitivity of investment increases monotonically in the degree of financing constraints. In fact, they report that firms classified as not financially constrained display a stronger sensitivity of investment to cash flow than firms that are likely constrained.

The strength of the KZ97 analysis is that it provides a very simple model of investment under financing constraints. The model shows that the nonmonotonic relationship between the investment-cash flow sensitivity and informational problems may result directly from the underlying structure of the marginal cost of external finance and the curvature of the marginal product of capital function. The simple maximisation problem that KZ97 consider is given in $(2.28)$,

$$
\max \Pi(I)-F(E, k)-I
$$

s.t. $I=W+E$,

31 A similar critical review is conducted by Schnure (1997), who investigates the finances of the non-oil segments in conglomerates that are the unit of analysis in Lamont (1997). Lamont (1997) investigates the sensitivity of investment by non-oil segments after an unexpected fall in cash flow from oil segments after the oil price collapse in 1986. Schnure argues that most segments analysed by Lamont do not behave after this event as if they face binding financing constraints. In particular, the segments are generally cash-rich (compared to industry peers), increase dividend payments on average, repurchase stock, and issuc public debt. Interestingly and in line with Kaplan and Zingales (1997), Schnure concludes that the small fraction of the segments that does behave as if it is financially constrained consists of firms involved in defaults and debt restructuring. 
where $\Pi(I)$ is the revenue function which is dependent only on the current investment level, $I$, and $F(E, k)$ represents the premium paid on external finance, which depends positively on both the level of external funds acquired $(E)$ and the degree of informational problems $(k)$. Investment is financed by a combination of internal funds $(W)$ and external funds. Note that the model assumes a $100 \%$ depreciation rate (negating the need for modelling capital stock adjustment technology) and requires firms to exhaust internal funds before turning to external sources of finance. The possible implications of these highly simplifying assumptions are discussed in the next subsection.

The sensitivity of investment to changes in wealth can be derived from the first-order condition of (2.28):

$$
\frac{\partial I}{\partial W}=\frac{F_{E E}}{F_{E E}-\Pi_{I I}}
$$

where $Y_{X}$ represents the partial derivative of $Y$ with respect to $X$. Assuming a concave revenue function $\left(\Pi_{I X}<0\right)$ the sensitivity of investment to changes in wealth is shown by $(2.29)$ to depend on the convexity of the cost of external finance with respect to the amount of external finance raised.

Differences in this sensitivity are at the centre of attention in empirical studies on financing constraints. The partial derivatives of $(2.29)$ with respect to wealth and informational problems are given in (2.30) and (2.31) below.

$$
\begin{aligned}
& \frac{\partial\left(\frac{\partial H}{\partial W}\right)}{\partial W}=\left(\frac{\Pi_{I I I}}{\Pi_{I I}^{2}}-\frac{F_{E E E}}{F_{E E}^{2}}\right) \frac{\Pi_{H}^{2} F_{E E}^{2}}{\left(F_{E E}-\Pi_{H}\right)^{3}} \\
& \frac{\partial\left(\frac{\partial H}{\partial W}\right)}{\partial k}=\frac{F_{E E k} \Pi_{I I}\left(\Pi_{I I}-F_{E E}\right)+F_{E k}\left(F_{E E E} \Pi_{I I}-F_{E E} \Pi_{I I}\right)}{\left(F_{E E}-\Pi_{I I}\right)^{3}}
\end{aligned}
$$

KZ97 focus on changes in wealth (2.30) in their critical review, which results in a monotonic increase in the sensitivity of investment to cash flow only if "there is a certain relationship between the curvature of the production function and the curvature of the cost function at the optimal level of investment" (KZ97, $\mathrm{p}$. 175). Fazzari et al. (2000) stress that the empirical test should not explore the investment-cash flow sensitivity for firms with different levels of wealth, but rather subdivides firms based on their expected degree of informational problems, i.e. they suggest sorting firms on the basis of their premiums. Hence they claim that equation (2.31) is an appropriate empirical test of financing constraints. Note that we demonstrated in section 2.3.4 that investment-cash flow sensitivities do not necessarily reflect differences in premiums between firms. Furthermore, it follows from (2.31) that the investment-cash flow 
sensitivity is not necessarily increasing in the degree of informational problems. $^{32}$

Thus, KZ97 provide both a theoretical framework that is critical of the notion of a monotonic relationship between the investment-cash flow sensitivity and financing constraints and they apply their argument empirically to the data used in the parent article of this field of research, FHP88. Note that KZ97 are not alone in their critical treatise of the financing constraints and investmentcash flow sensitivity nexus. Refer to Cleary (1999) for empirical findings on a representative sample of US firms that suggests that the most financially constrained firm actually display the lowest sensitivity of investment to cash flow. See also Chirinko (1997) for findings that are considerably less enthusiastic about the explanation of financing constraints underlying observed patterns in investment-cash flow sensitivities. Cleary (2000) is critical of the sample-size from which many of the mainstream results are drawn; he considers a lot of them very small and therefore sensitive to the behaviour of a rather small number of firms.

\subsubsection{Directions for further research}

The KZ97 analysis serves to (re)direct attention to the following important research questions in the analysis of financing constraints. First, KZ97 emphasise the availability of internal finance in their identification of constrained firms. This results in a classification scheme in which the firms labelled 'likely constrained" are those with the lowest $W$ in terms of the model outlined above. Fazzari et al. (1996 and 2000) express their concern over this classification result. ${ }^{33}$ Although high- $W$ firms face binding financing constraints

\$2 Specifically, Fazzari et al. (2000) assume a positive premium, one that increases in the amount of external finance $\left(F_{E E}>0\right)$ and does so at a faster rate for firms with a higher degree of informational problems $\left(F_{E E \text { t }}>0\right.$ ). Furthernore, assuming diminishing returns to investment $\left(\Pi_{n}<0\right.$ ), the denominator as well as the first term in the numerator of (2.31) are positive. A positive (2.31) overall still depends on the second term in the numerator, however. Let $F_{E K}>0$ (the premium rises in the degree of informational problems). Then, for a revenue function that is quadratic in $I\left(\Pi_{I I}=0\right)$ and a premium function quadratic in $E\left(F_{I H}=0\right)$, this second term is zero and (2.31) overall is positive. However, when $\Pi_{I I I}>0$, the second term is negative and may outweigh the first, suggesting lower cash flow sensitivity when the degree of informational problems increases.

33 In fact, Fazzari et al. (1996 and 2000) argue that K297 do not rank on the basis of $W$, but on the basis of financial distress. FHP8 explicitly aimed to exclude financially distressed firms from the analysis as this is an issue very much different from financing constraints. Econometrically, the result of including distressed firms in the empirical analysis may be censored regression bias that lowers the investment-cash flow sensitivity of the most likely financially distressed firms. This is due to the fact that investment cannot fall below 
with a higher probability than do low- $W$ firms in a static setup (see for instance figure 2.1), the straightforward connection between $W$ and financing constraints is lost when we consider firms to be forward-looking regarding their liquidity decision. Put differently, given informational problems in the capital markets and the possibility of binding financing constraints, it may be optimal for firms to take into account that financing constraints may become binding in the future and provide for a precautionary level of liquid assets, for instance. In this sense, high levels of internal funds may indicate the presence of binding constraints, rather than serving as an indication that financing constraints are not relevant. Chapter 5 of this thesis addresses the question of optimal corporate liquidity demand in an environment characterised by asymmetric information.

Second, the above-mentioned methodological concern also relates to a few important points of critique regarding the simple investment model presented by KZ97. In fact, the KZ97 theoretical model may be too simple to accurately analyse the problems at hand. The model is a static optimisation problem in which $W$-interpreted as the amount of internal funds available for investment, or retained earnings - is given exogenously. In that sense, $W$ is like manna from heaven. It is unclear where it comes from and in addition, its value in a more dynamic setting is not recognised. In a more realistic setting, one might expect that the amount $W_{r}$ with which the firm starts period $t$ is determined in the past and the need for a certain level of $W_{i+1}$ is also taken into account in the investment and financing decisions in period $t$. The value of $W_{t}$ and the decision over $W_{t+1}$ stems from the objective to inter-temporally minimise the cost of finance. Hence a firm with low $k_{t}$ but high expected $k_{t+l}$ has an incentive to finance current investment with more external finance than it would in a one-shot investment decision, since this avoids higher costs of external finance in period $t+l{ }^{34}$ Chapter 6 of this thesis addresses the question of how important firms deem the adjustment of liquidity holdings over time to targeted levels and to what extent this importance is dependent on the sign and size of the deviation.

Third, KZ97 assume that observed levels of internal wealth are useful measures of financing constraints. This allows them to interpret their empirical findings as saying that the investment-cash flow sensitivity is not. However, when observed levels of internal funds do not associate monotonically with

zero - probably not even below a low positive level - while cash flow can take on negative values and likely does so in the case of financial distress.

34 Note how this argument runs parallel to the inter-temporal minimisation of the capital stock adjustment costs within the Euler equation framework. See also equation (2.17) and footnote 11 above. 
financing constraints even though the investment-cash flow sensitivity does; then it is unclear whether firms with lower levels of internal funds should display a stronger sensitivity of investment to cash flow. In this regard, we should note that some of the more recent theoretical contributions to the debate include a dynamically optimal demand for internal funds in an environment with financing constraints. These contributions demonstrate that a nonmonotonic relation between the level of internal funds and the degree of financing constraints is possible. Dasgupta and Sengupta (2001), for instance, develop a model in which the decision over the amount of internal funds to transfer to the future in the form of liquidity depends on expected future profitability and expected future financing constraints. The result of this richer theoretical specification is that it is not unlikely "for more constrained firms to end up with higher cash endowment today and show greater cash flow sensitivity of investment" (Dasgupta and Sengupta, 2001, p. 3), supporting the notion that the level of internal funds may not accurately reflect financing constraints. Chapter 7 of this thesis provides a comprehensive analysis of the connection between liquidity holdings, financing constraints, and the investment-cash flow sensitivity.

\subsection{Summary and conclusions}

There is by now a considerable body of empirical evidence that suggests that financing constraints can be assessed by exploring the cash flow sensitivity of corporate investment. Furthermore, most studies employing some form of split sample analysis find that firms expected to face (more severe) financing constraints display a stronger sensitivity of investment to cash flow. This chapter provides an overview of this literature as well as a discussion of a recent strand that is highly critical of the empirical strategy used to detect binding financing constraints.

In section 2.2, a general dynamic capital demand model is subjected to costly external finance and testable implications regarding financing constraints are presented in a Q-model, an Euler equation framework, and a reduced form investment model. It is stressed that the Q-model and reduced form investment equations may be particularly liable to systematic errors in measuring investment fundamentals. This may result in investment-cash flow sensitivity patterns in line with - but not resulting from - binding financing constraints. The sufficient conditions for valid inference from empirical results, being either exogenous regime selection or exogenous changes in internal funds, are explored in detail in section 2.3. This section furthermore elaborates on the extent to which empirical tests on financing constraints reflect the role of 
asymmetric information in the premium on external funds as well as the extent to which the magnitude of this premium can be assessed in standard tests. We argue that the informational content of the financing constraint is difficult to assess. Also, empirical strategies that focus on the identification of those firms who most likely face binding constraints are not the strategies that are most successful in sorting out the firms with the highest premiums on external finance.

Sections 2.2 and 2.3 are then taken as the structure within which a wide variety of empirical papers is compared in section 2.4. The results from a comparison of US studies provide an indication of the extent to which conclusions drawn from a relatively homogeneous selection of data sets are sensitive to specific choices made regarding for instance the specification of the investment function and sample splitting criteria. The findings of higher investment-cash flow sensitivities for firms expected to face binding financing constraints are robust to such choices. Furthermore, individual studies have tackled the methodological concerns raised in section 2.3 and still report evidence in line with a financing constraints explanation. In the next chapter, we add to this literature by analysing the role of the liquidation value of a firm "s capital stock in the connection between corporate investment and corporate finance. There, we find that expected liquidation costs significantly associate with the sensitivity of investment to financial factors, i.e. firms for which these costs are lowest display the weakest sensitivity of investment to cash flow. This finding emphasises the important role of collateral in ameliorating informational problems in capital markets. In chapter 4 , we assume costly external finance as given and explore the optimal response of multi-divisional firms to this external constraint. In theory - and in the absence of internal incentive problems - the firm benefits from internal re-allocation of funds between divisions, such that the marginal returns on investment are equal across all divisions. However, out empirical results suggest that such an optimal response is not automatic, but requires a supportive organisational structure.

Overall, in section 2.4 we have displayed a broad body of empirical evidence that is supportive of a financing constraints explanation in the sense that the firms that are classified as most financially constrained also display the strongest sensitivity of investment to cash flow. In section 2.5 of this chapter, however, we discussed a relatively novel strand of literature that is highly critical of this reading of the evidence in general and the interpretation of investment-cash flow sensitivities as useful measures of financing constraints particular. This criticism builds on the unsatisfactory explanation in the mainstream financing constraints literature of particularly the following two observations, which serve as a foundation for part II of this thesis. 
First, firms with high investment-cash flow sensitivities may be rather rich in terms of the amount of internal finance they have available, suggesting that they are, in fact, not constrained at all. This observation triggers questions that are answered in chapters 5 and 6 of this thesis, which concentrate on the empirical analysis of Dutch corporate liquidity holdings. In chapter 5 we consider the question why firms structurally invest in low-yielding liquid assets. There, we explore the determinants of corporate liquidity holdings and compute long-run targets. We explicitly allow for and find evidence of precautionary holdings of liquid balances that relate to capital market imperfections. In chapter 6 we examine the importance of long-run target levels of corporate liquidity holdings in terms of how swift firms converge towards these targets in the short run. There, we document that especially large deviations from these targets incite swift adjustment.

Second, firms with the lowest stocks of liquid internal funds are not necessarily the ones that exhibit the highest sensitivity of investment to cash flow. This observation motivates chapter 7 of this thesis. There, we analyse the corporate liquidity decision in connection with financially constrained investment. We argue that observed corporate liquidity holdings are not useful measures of financing constraints and examine the connection between shortages of liquidity relative to targets and the sensitivity of corporate investment to cash flow instead. 


\section{Chapter 3 \\ Costly Liquidation and Costly External Finance}

\subsection{Introduction}

Liquidation is costly. The exact cost of liquidation, however, depends on many factors and is therefore difficult to predict. The factor that we consider empirically in this chapter is to whom you can sell your assets in the event of a liquidation. Whoever is the next-best user of your assets is also willing to pay the highest price, reducing your liquidation costs. For a firm, other firms in the same line of business are likely to be the next-best users and thus potential purchasers of its assets (cf. Shleifer and Vishny, 1992; Hart, 1995). Hence, expected liquidlation costs are lower when the firm can expect to sell its assets to an industry peer than when it may have to sell its assets to a firm in another line of business. If firm and industry sales are highly correlated - when there is a high degree of comovement (cf. Guiso and Parigi, 1999) - firm and industry face declining demand at the same time. Then, industry peers likely face difficulty in generating the funds to purchase second-hand capital assets from liquidating competitors, or find no interest in expanding their capital stocks. Therefore, the probability that a firm is able to sell its assets to a next-best user-and hence the liquidation value-decreases when the degree of comovement of firm and industry sales rises.

In this chapter we are primarily interested in the extent to which costly liquidation has an impact on the interdependencies between corporate investment and finance. The underlying idea is as follows: the firm's ability to finance planned investment with debt increases if the firm can provide collateral to a creditor when it takes out a loan. The provision of collateral facilitates debt accumulation through two channels. First, it allows the firm to arrange collateralised, inexpensive loans, rather than uncollateralised, expensive loans (cf. Hubbard, 1998). Second, it possibly increases a firm's debt capacity and reduces the probability of running into a binding debt capacity constraint (cf. Whited, 1992).

The ability of a firm to provide collateral depends among other factors on the expected liquidation value of its assets, which increases with better possibilities to resell its capital stock. Hence a firm's ability to raise (collateralised) debt improves when expected liquidation costs fall (cf. Shleifer and Vishny, 1992). We 
therefore expect that investment is more dependent on financial considerations for firms that face high liquidation costs, i.e. that are characterised by a higher degree of comovement.

The focus on firm-industry sales comovement as an empirical measure of liquidation costs also highlights an infrequently investigated aspect of financing constraints, namely the extent to which financing constraints are associated with the way the firm performs in relation to its environment. So far, the vast majority of studies have analysed firm-level aspects of financing constraints. ${ }^{2}$ Relatively few studies have explored industry-level aspects, of which Worthington (1995) is the most relevant example for the present analysis. ${ }^{3}$ Worthington distinguishes between cyclical and noncyclical industries based on the same connection between liquidation costs and debt accumulation that we hypothesise. The innovative feature of our measurement of liquidation costs lies in its specific focus on the relation between a firm and its environment, arguing that for firms whose sales behave procyclical relative to industry sales, assets may be of less use as collateral to loans.

We estimate reduced form investment equations on a balanced panel of 206 large and mature Dutch firms for the period 1992-1996. We use information from the 1983-1991 period to determine the degree of comovement as well as a few firm-level classifications of financing constraints. Our main empirical findings are the following. First, we find that comovement associates positively with the sensitivity of investment to cash flow. We interpret this as evidence that costly liquidation associates with financing constraints in investment. The emphasis on liquidation costs in the analysis of corporate investment necessarily demands a discussion of the effect of costly reversibility on optimal investment plans. Costly liquidation associates with costly reversibility, or partial irreversibility, because of the wedge it drives between the purchase and selling price of a firm's capital stock (cf. Abel and Eberly, 1994, 1996). Irreversibility affects investment demand negatively when there is an option to wait (e.g., Abel et al., 1996; Dixit and Pindyck, 1994). Hence through this channel liquidation costs may reduce the incidence of financing constraints. Our empirical analysis reveals that this channel is at best of secondary importance. Second, we explore the relation between our classification of firms on the basis of comovement and a number of frequently used, firm-level classification schemes - like retention practice and firm size - and

2 Refer to the overview of studies in tables 2.1 and 2.2 for an illustration of this statement:

Other relevant contributions in this regard are Schaller (1993), Chirinko and Schaller (1995) using a sample of Canadian firms and Weigand and Audretsch (1999) with data. on German firms. 
find that high comovement firms typically do not retain a larger or smaller fraction of earnings, nor are they particularly larger or smaller than their low comovement peers. Hence we claim that our focus on the relation between firm and environment leads to new insights regarding the working of financing constraints.

The chapter proceeds as follows. Section 3.2 discusses the empirical investment equation. In section 3.3 we discuss the theoretical connections between liquidation, finance, and investment. Here we also introduce the data and construct our empirical measure of liquidation cost. Estimation results are presented and discussed in section 3.4. There, we also examine to what extent our classification of firms on the basis of comovement reflects the information embedded in some well-known classification schemes. Section 3.5 summarises and concludes.

\subsection{The empirical investment equation}

We characterise optimal firm-level investment with a simple sales accelerator type investment model:

$$
\text { (3.1) } \Delta k_{t}=\alpha_{0}+\alpha_{1} \Delta k_{t-1}+\alpha_{2} \Delta y_{t}+\alpha_{3}\left(y_{t}-k_{t-1}\right)+\varepsilon_{t}
$$

where $k=\ln (K), y=\ln (Y), K$ denotes the capital stock, $Y$ denotes output, and $\varepsilon$ is an error term. This investment function results for instance from the specific reduced form investment model we discussed in section 2.2 .3 , if we impose an $\mathrm{ADL}(2,1)$ specification of the capital stock adjustment process ${ }^{4}$ and disregard (changes in) the real rental price of capital. ${ }^{5}$ We refer to Galeotti et al. (1994), Harris et al. (1994), or Schiantarelli and Sembenelli (2000) for alternative modelling of investment that produces empirical investment equations very similar to $(3.1)$.

Equation (3.1) is derived from an investment decision that does not consider the financing decision. This is justified under the assumption of perfect capital markets so that the irrelevance theorem holds. However, financing becomes nontrivial in the investment decision when firms face binding finaneing constraints. In

4. Any ADL $(n+1,1)$ specification of capital stock adjustment generates investment equation (3.1) with the modification that $n$ lags of the dependent variable are introduced to the right-hand side. For our analysis, we found that $n=1$ suffices for dynamic vallidity of the empirical investment equation, while further lags did not add a lot of explanatory power.

5 Chirinko (1993) shows that price information is unimportant relative to quantity information in empirical inwestment equations. More importantlly ${ }_{*}$ omilting this price information does not considerably change the other parameter estimates. Also see Chirinko, Fazzari, and Meyer (1999). 
the latter case, a proper characterisation of investment has to take into account the financing side as well. In particular, the investment decision now also depends on changes in internally available funds (cf. Fazzari et al., 1988). We add cash flow (Cf) to the investment equation to capture this financing channel. We expect that cash flow affects investment positively - after controlling for investment opportunities - when financing constraints are relevant. Following the extensive discussion of the possible correlation of cash flow and unobserved innovations in investment opportunities in section 2.3.2, we have to make sure that our cash flow effect is not contaminated by such correlation. We do so by instrumenting the cash flow variable with lags of its own value. This way, only predicted variation in cash flow is related to the investment decision. Unexpected innovations to cash flow, which may or may not be correlated with unobserved innovations to investment opportunities, are therefore not taken into consideration.

Additionally, we implement the idea developed by Fazzari and Petersen (1993) that the impact of working capital investment $\left(\Delta W_{C}\right)$ in the (fixed capital) investment equation also signals the relevance of financing constraints. Here we apply the idea that in addition to the investment in fixed capital investment in working capital is important to the firm. Now suppose that, despite our use of an instrumental variables approach, a positive cash flow sensitivity of investment still reflects nothing more than the correlation of (predicted) cash flow with unobserved innovations to investment opportunities. ${ }^{6}$ In this scenario, an unobserved improvement in investment opportunities would provide an incentive for the firm to increase investment in both fixed and working capital. Hence, unobserved innovations to investment opportunities would produce not only a spurious (positive) correlation between cash flow and fixed capital formation, but likewise between investment in working capital and fixed capital formation. Suppose, alternatively, that a positive cash flow sensitivity correctly measures the impact of financing constraints. Then, working capital competes with investment in fixed assets for a limited pool of internal funds. Hence, investment in fixed capital given the amount of internal finance available - can be expanded only at the expense of lower investment in working capital. A negative parameter estimate on working capital investment results.

Investment in working capital is therefore added to the investment equation to provide additional insight into the relevance of financing constraints. A negative parameter estimate for working capital investment signals the competition of fixed and working capital investment for limited internal resources and therefore supports the interpretation of a positive cash flow sensitivity of investment as

6

For instance, cash flow may be a leading indicator of future investment opportunities. Then cash flow predictions based on past cash flow realisation may still correlate with (unobserved) innovations to investment opportunities. 
stemming from financing constraints. ${ }^{7}$ As in the case of cash flow, however, we have to consider the possibility that working capital investment may be endogenous in the fixed capital investment equation. Specifically, the argument can be made that firms facing a positive shock to investment opportunities may reduce working capital investment not because of binding financing constraints, but simply because this is the least costly short-run adjustment. The case for binding financing constraints is much stronger if we can show that firms plan to curtail investment in working capital to free up funds for planned investment in fixed assets. ${ }^{8}$ Hence we also instrument working capital investment (with lags of its own value), so that only its predicted values drive the investment decision.

The empirical investment equation is then:

$$
\begin{aligned}
& \frac{I_{i t}}{A_{i, t-1}}=\beta_{0} \frac{I_{i, t-1}}{A_{i, t-2}}+\beta_{1} \Delta y_{i t}+\beta_{2} \ln \frac{Y_{i t}}{A_{i, t-1}} \\
& +\beta_{3} \frac{C f_{i t}}{A_{i, t-1}}+\beta_{4} \frac{\Delta W c_{i t}}{A_{i, t-1}}+\lambda_{t}+\eta_{i}+v_{i t},
\end{aligned}
$$

where the variables are indexed by firm $(i)$ and year $(t), I$ captures investment in fixed assets, $A$ measures total assets, $\lambda_{t}$ and $\eta_{i}$ capture time-and firm-specific random effects, respectively, and $v_{i t}$ is a white-noise error term with the usual properties.

For unbiased estimates on sales growth and the sales-to-assets ratio, we also instrument these variables appropriately in the empirical analysis. Lastly, since lagged investment enters on the right-hand side of the regression equation and we modell a firm-specific error component, we have to consider and correct for the correlation between lagged investment and the regression error. We use the Arellano and Bond (1991) dynamic panel estimation methodology to compute consistent parameter estimates. ${ }^{9}$

Furthermore, Fazzari and Petersen (1993) suggest that if working capital is excluded form the empirical model, cash flow sensitivities may be underestimated.

8 See Shyam-Sunder and Myers (1999) for a simillar argument in the case of capital structure adjustment.

更

In the absence of serial correlation, our assumptions regarding the properties of the error term are valid and inference from our estimates is appropriate. Within the Arellano and Bond framework, we test for the absence of second order serial correlation to check our dynamic specification. 


\subsection{Liquidation, finance, and investment}

In this section we elaborate on the theoretical arguments that relate costly liquidation to the interdependence of corporate investment and finance. Specifically, in subsection 3.3.1 we first discuss how liquidation costs - via costly reversibility - impact on corporate investment demand and subsequently we examine the role of costly liquidation on the cost of external finance. We then turn to the empirical measurement of liquidation costs. In subsection 3.3.2 we introduce the data and in subsection 3.3 .3 we estimate our proxy for liquidation costs: firmindustry sales comovement.

\subsubsection{Theoretical considerations}

Reversibility of investment affects both the demand for external funds and its supply. We discuss these two issues in turn. On the one hand, costly liquidation makes reversibility of investment costly due to the wedge it drives between the purchase and selling price of a firm's capital stock. Let us briefly consider how costly reversibility affects a firm's optimal investment demand. Dixit and Pindyck (1994) consider costly reversibility of investment when the firm has the option to invest now or wait until uncertainty over the profitability of investment is resolved. Uncertainty in combination with costly reversibility may delay investment when there is an option to start the same project at a later date. ${ }^{10}$ This lowers current investment demand and - in a finaneing constraints setting with a given level of internal funds - reduces the probability that a firm is in need of costly external finance or runs into a binding debt capacity constraint.

On the other hand, costly liquidation affects the interdependence of corporate investment and finance via the supply of costly external finance. Shleifer and Vishny (1992) illustrate the argument neatly by considering expected liquidation costs for firms that operate in sectors characterised by mainly idiosyncratic or industry-wide shocks to performance. In case of mainly idiosyncratic shocks, firms forced to liquidate likely find well-performing industry peers - considered to be the next-best users of a firm's assets - who are interested in purchasing its assets and willing to pay a price close to their true value. In contrast, if performance shocks are mainly industry-wide, industry peers find no interest in purchasing the assets of a liquidating firm. Then, assets must be sold to industry outsiders at values below their true value. The discount arises from the lower value that industry outsiders derive from a firm"s specific assets, but also from their fear to overpay as they cannot value these assets properly (effectively

10. Also see Trigeorgis (1996) for an extensive analysis of the role of real options in corporate investment. 
considering them as lemons). This results in costly liquidation which makes assets less valuable as collateral to loans. The result is a more heavy reliance on uncollateralised, expensive debt and possibly a lower debt capacity and a binding debt capacity constraint. "For a given demand for investment, therefore, we expect firms to be more financially constrained when liquidation costs are higher.

Theoretically, therefore, the impact of costly liquidation on the probability that firms experience financing constraints is ambiguous. On the one hand, costly liquidation makes waiting more valuable and reduces current investment demand. This lowers the demand for external funds and results in a lower probability that firms face financing constraints. We thus hypothesise empirically that if this demand channel dominates, then the cash flow sensitivity of investment for high comovement firms should be lowest. On the other hand, high liquidation costs raise the price of external funds and/or limit its supply. Through this supply channel, liquidation costs increase the probability that firms face financing constraints. Hence the sensitivity of investment to cash flow rises with comovement when this channel dominates. For the remainder of this analysis we assess empirically which of these two channels dominates.

\subsubsection{The data}

In the empirical analysis we make use of Statistics Netherlands' SFGO sample, which collects balance-sheet and income statement data on a nonrandom sample of Dutch firms. The sample is devised to collect information on the entire population of Dutch firms for which the total balance sheet length exceeds NLG 20 million in current prices. In practice, the annual response rate is roughly eighty percent, so that the SFGO sample includes nearly 30,000 firm-years of observation, covering the period 1977-1997. We extract from this sample a balanced panel of manufacturing firms (sectors 20-39 according to SBI74 classification). By doing so, we follow the majority of papers in this field of research. Due to attrition, we select the years ranging from 1983 to 1996 so that we have information on all the relevant variables in the investment equation for a total of 206 firms.

Our sample thus exclussively contains large Dutch firms. Furthermore, the choice for a balanced panel possibly selects from this data the most financially healthy firms and likely also the most mature firms. Large and mature firms are typically regarded to face the smallest premium on external finance. ${ }^{12}$ In terms of

11 See for instance Whited (1992) or Hu and Schiantarelli (1998) for an empirical anallysis of financing constraints with binding debt capacity constraints.

Si. See for instance Devereux and Schiantarelli (1990), Oliner and Rudebusch (1992), Schaller (1993), Carpenter et all. (1994), Galeotti et al. (1994), Chirinko and Schaller (1995), Gilchrist and Himmelberg (1995, 1998), Hubbard et al. (1995), Jaramillo et all. (1996). 
the present analysis, therefore, we may be using a sample that is particularly biased against finding any effects of financing constraints in investment. Hence our estimated investment-cash flow sensitivities are conservative and the implied relevance of liquidation costs in explaining financing constraints should be considered as a lower bound to its importance in the representative Dutch manufacturing firm.

\subsubsection{Measuring liquidation costs}

Contrary to Shleifer and Vishny (1992) and also Worthington (1995), we do not consider industry-specific features of performance shocks to characterise (industryspecific) liquidation costs. Instead, we emphasise the cyclical performance of a firm relative to its industry peers. Hence, in our analysis liquidation costs are specific to the firm and result from the way the firm operates relative to its industry peers. We proxy liquidation costs as proposed by Guiso and Parigi (1999). We "construct an indicator of asset liquidity at the firm level [by] measuring the correlation [of output] of the firm with its industry" (Guiso and Parigi, 1999, p. 208). The higher this correlation, the more firm performance comoves with industry performance, resulting in lower asset liquidity and higher expected liquidation costs. Specifically, we measure comovement as the correlation between firm and industry real sales growth rates. ${ }^{13}$ To that end, we sort the 206 firms in our sample into nineteen 2-digit manufacturing sectors and obtain sector real sales growth rates from Statistics Netherlands (see the appendix for computational details). We use the period 1983-1991 to compute comovement. The reason for using only part of our sample period is that the standard industry classification has been revised considerably from 1992 to 1993 . Hence the $1983-1996$ firm-industry sales correlations could show discrete breaks in 1992 that are not due to sudden changes in the way firms perform relative to their environment; but simply due to a re-definition of their environments. Furthermore, due to data limitations we cannot compute comovement for fourteen firms (see the appendix).

The resulting comovement variable varies from -0.90 to 0.92 between firms, but for each firm separately it is a constant. Mean and median comovement is 0.07 and 0.11 , respectively. For the remainder of this analysis we consider comovement to be low when it falls below -0.21 (the first quartile of the comovement distribution), medium when it is in between -0.21 and 0.36 (the second and third

Also see tables 2.1 and 2.2 .

13. Alternatively, we have measured comovement as the correlation between firm and industry real sales levels. This does not change any of the conclusions that we draw later on, however. 
quartiles), and high when it exceeds 0.36 (the fourth quartile). ${ }^{14}$

\section{Table 3.1}

Descriptive statistics: 1983-1991

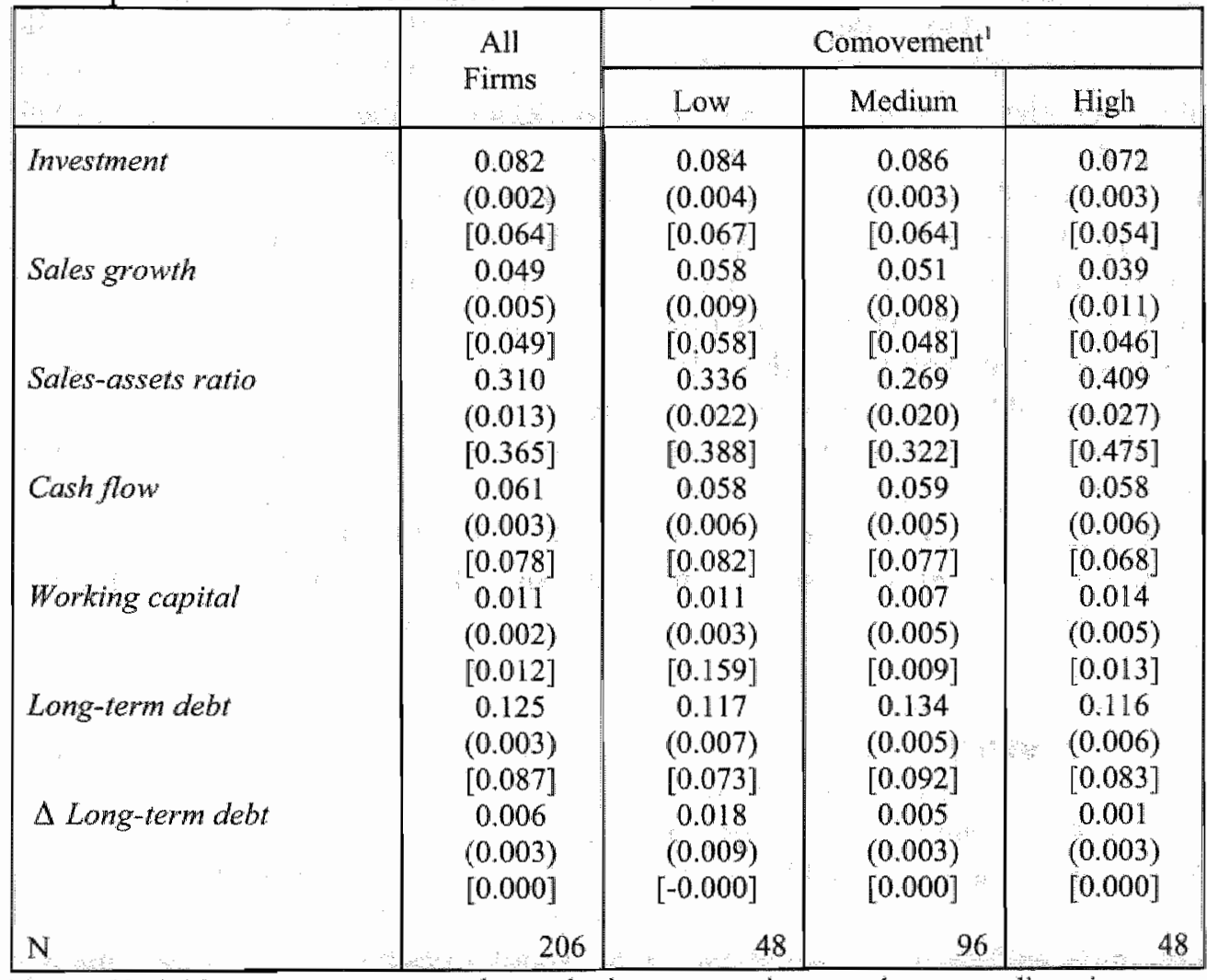

Notes: Variable means are reported, standard errors are in parentheses, medians in square brackets. Investment is defined as changes in tangible fixed assets due to purchase or production over total assets; Sales growth is the first difference of the natural logarithm of total sales; Salesassets ratio is the log of sales minus the log of total assets; Cash flow measures earnings after interest and taxes, but before depreciation and dividends over total assets; Working capital measures investment in cash, inventories, and short-term claims minus short-term debt relative to total assets; $(\Delta)$ Long term debt is (the change in) long-term debt over total assets.

1 Comovement is low when the firm-industry sales growth correlation is less than -0.206 (the $25^{\text {th }}$ percentile), it is medium when this correlation is in between -0.206 and 0.363 (the $75^{\text {th }}$ percentile), and it is high when the correlation exceeds 0.363 .

Quartiles 2 and 3 are merged into medium comovement following initial estimation results. 
Table 3.1 provides an indication of which types of firms are considered to be financially constrained on the basis of comovement. Investment is roughly equal for low and medium comovement firms, but considerably lower for high comovement firms. Furthermore, a higher degree of comovement associates with slower sales growth rates. These observations are all supportive of a financing constraints explanation; costly external finance curtails a firm's investment and slows its sales growth rate. We also observe from the table that high-comovement firms display a lower rate of long-term debt accumulation. Especially this last observation fits the hypothesis that comovement is associated with financing constraints through a lower expected liquidation value of a firm's assets: more costly liquidation makes assets less valuable as collateral to loans and thus hampers debt accumulation. At the same time, based on the information in table 3.1, we cannot reject an explanation along the lines of irreversible investment. Specifically, with a valuable option to delay investment, the observed investment and sales growth rates should also be lower for high-comovement firms. Their lower investment demand reduces their demand for external funds, which then explains their slower rate of long-term debt accumulation. Distinguishing between these two alternative explanations requires a more careful look at the investment decision, to which we now turn.

\subsection{Estimation results}

\subsubsection{Comovement and financing constraints}

We compute dummy variables to indicate whether a firm is characterised by low comovement ( $\left.D^{\text {Low consvement }}\right)$ or high comovement ( $\left.D^{\text {High comovement }}\right)$ and interact these dummies with cash flow and working capital investment. Subsequently, we estimate equation (3.2), including interaction terms, for the period 1992-1996. We use this period, rather than the full fourteen sample years, to compute estimates so as to minimise the correlation between unobserved innovations to investment opportunities and our classification scheme (for which we used the 1983-1991 period). Also refer in this regard to section 2.3.1. We hasten to admit that the probability that a firm can or wants to adjust the cyclical nature of its sales growth relative to its industry peers as a response to such innovations is small. However, in section 3.4.2 we compare our results on comovement with findings on other classification schemes for which a connection with unobserved innovations to investment opportunities is much more likely. In order to make this comparison as fair as possible, we already separate classification (1983-1991) and estimation (1992-1996) periods here.

Table 3.2 presents the estimation results. Let us first focus on the results in columns (1), (2), and (3). The regression results indicate that sales growth does not 
significantly contribute to the explanation of investment outlays. The sales-assets ratio fares much better; it is positive and significant in all instances. The estimation results furthermore show a strong degree of persistence in investment rates, indicated by the parameter estimate on lagged investment well in excess of 0.50 . Cash flow, when it is added to the investment equation, carries a positive and significant parameter estimate. Moreover, the impact of cash flow on investment is not affected by the inclusion of working capital investment in the investment equation. The latter has a negative and significant impact on investment, indicating that working capital and fixed asset investment compete for a limited pool of finance. ${ }^{15}$ This already provides some preliminary support for the relevance of financing constraints in the Dutch manufacturing sector.

Regarding the test statistics in panel B of the table, the SOSC specification test first of all demonstrates the validity of our dynamic specification of investment by the absence of significant second order serial correlation. Furthermore, the Sargan tests on over-identifying restrictions support the validity of our instrument sets. Additional checks on the validity of the instruments used are summarised in the Difference Sargan (DS) tests. Here our instrument set is evaluated against alternative sets that put restrictions on the inclusion of recent lags of explanatory variables, testing the hypothesis that these recent lags are not correlated with unobserved innovations to current investment opportunities. The test statistics indicate that this hypothesis cannot be rejected in response to any of the restrictions that we consider. Hence we find no objections against the instruments used.

In order to assess the role of financing constraints, we examine the excess sensitivity of constrained furms' investment to financing variables in columns (4) and (5). Excess sensitivity is tested for by looking at the interactions of cash flow and working capital investment with the two dumny variables indicating high and low comovement. The results in column (4) show that in terms of the cash flow sensitivity of investment, comovement indeed associates with financing constraints. In particular, when comovement is low (and the expected liquidation value of assets is high) corporate investment is least sensitive to cash flow, while the opposite holds for those firms for which comovement is high. These results are insensitive to the addition of the interaction terms on working capital investment (column (5)). For low comovement firms, we additionally observe that investment is least sensitive to working capital investment.

15 The magnitude of the parameter estimate is much lower than that presented in for instance Fazzari and Petersen (1993). Their estimate, derived from a Q-model, is $-0.43(-0.18)$ for (un)constrained firms. For regressions including sales, they still find a working capital impact of -0.22. Our findings are more in line with Weigand and Audretsch (1999), who find a working capital impact on investment of -0.12 within a reduced form investment equation approach. 


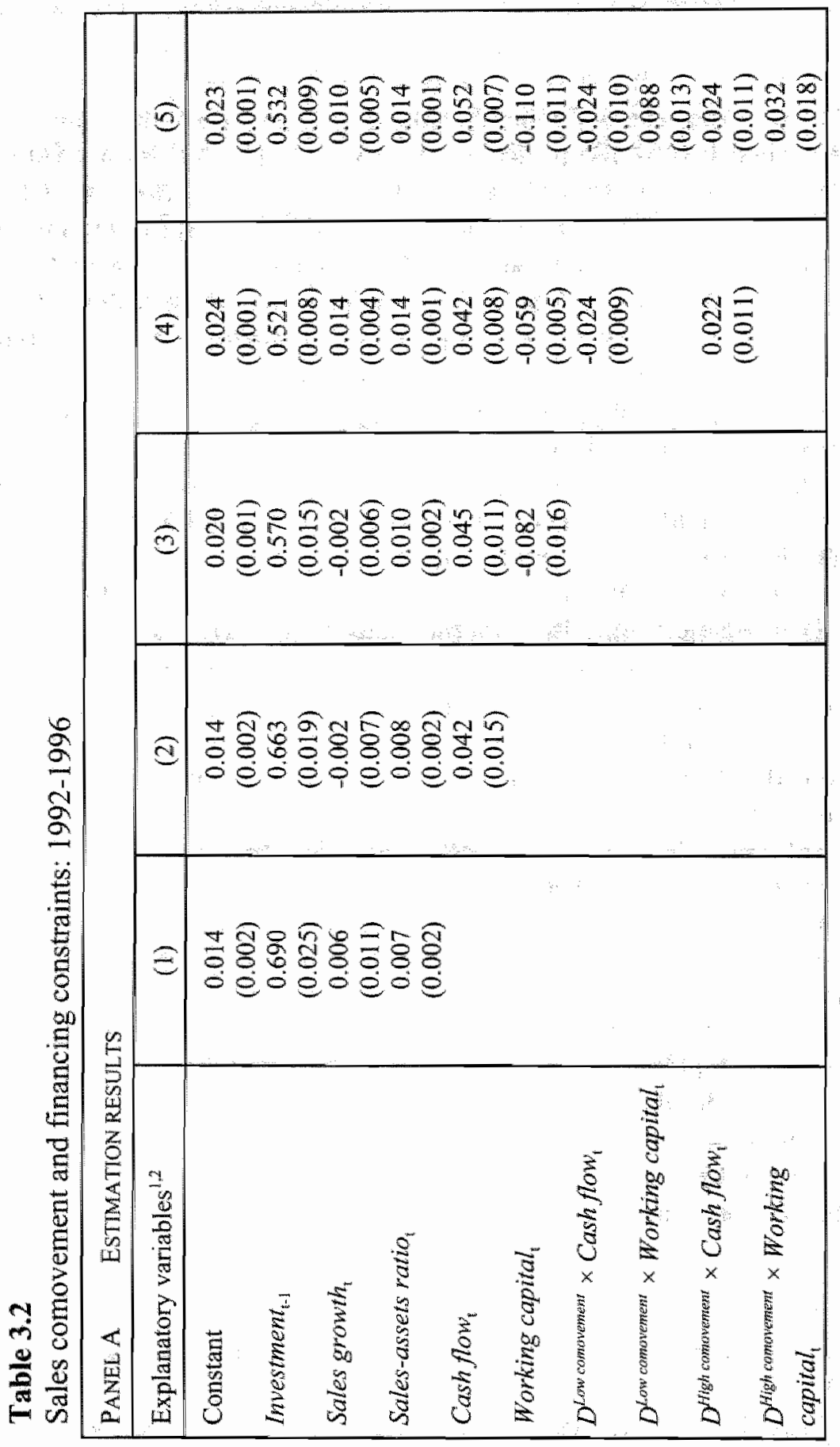




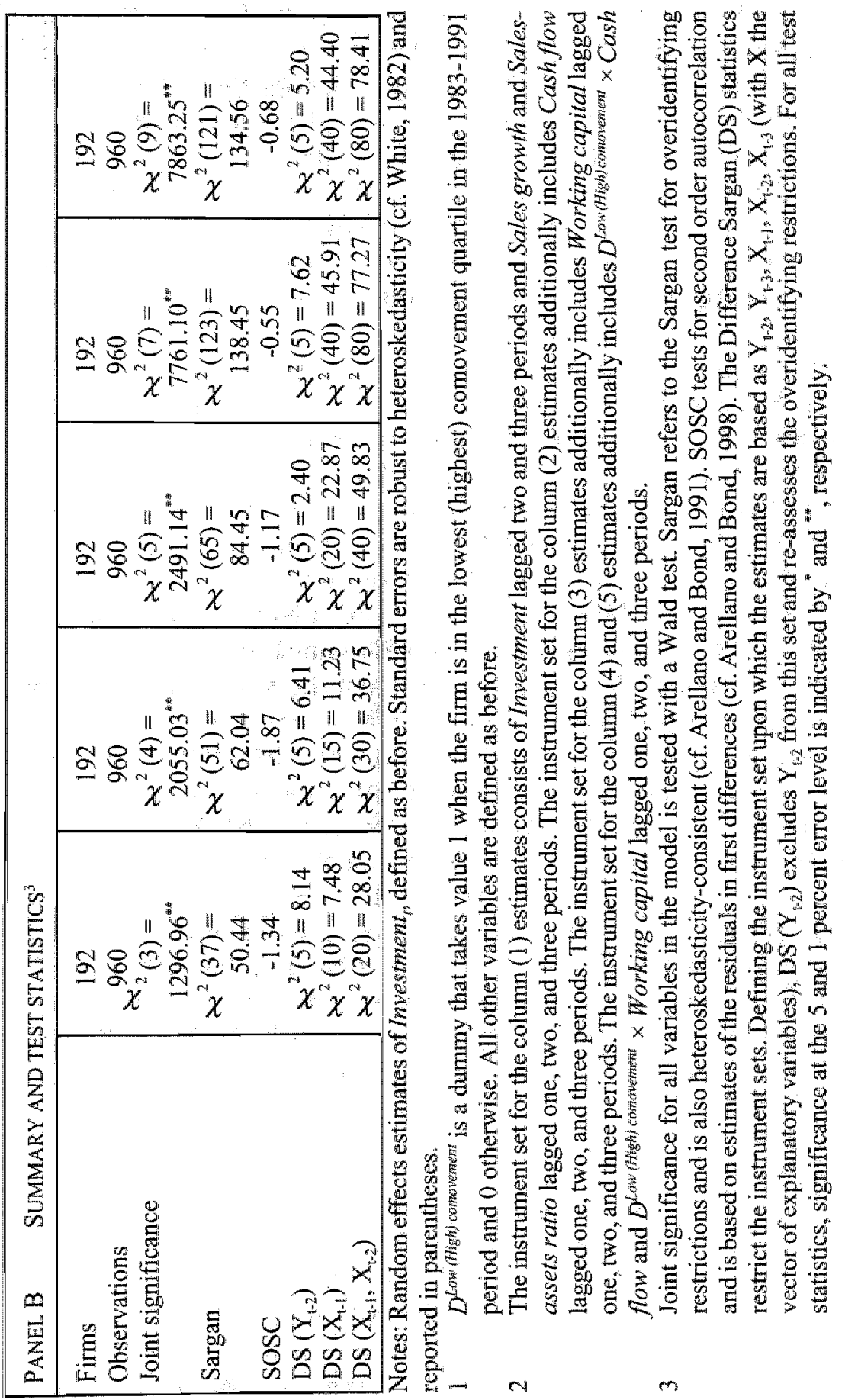


These are precisely the results we would expect if high comovement indicates a relatively heavy reliance on uncollateralised, expensive loans and a larger probability of facing a binding debt capacity constraint. Put differently, these results support the dominance of the supply channel, discussed in section 3.3.1. More importantly, these are not the expected results if comovement affects investment primarily - via partial irreversibility - through the demand channel. Then, high-comovement firms would be those for which the demand for external finance is lowest, which reduces the sensitivity of their investment decision to cash flow. This channel is at best of secondary importance and for our sample of firms is outweighed by the supply channel effect.

We want to conclude with a discussion of what this pattern of excess sensitivity tells us along the lines of subsections 2.3.3 and 2.3.4. More specifically, does excess sensitivity reflect the fact that a larger proportion of high comovement firms faces a binding debt capacity constraint (although the premium they pay on external finance is similar to that of low comovement firms) or is it the larger premium these firms pay on uncollateralised external finance that explains this pattern (even though, on average, they do not run into binding debt capacity constraints more often than low comovement firms)? Note in this regard that comovement is a strictly time-invariant measure of liquidation costs. Since firms typically do not face binding (debt capacity) constraints in every individual sample year - even though we consider them more likely to do so - our classification on comovement probably does not sort out only those firms that face binding constraints from those that do not. Hence, some low comovement firms possibly face binding constraints during specific sample years, whereas some high comovement firms need not face binding constraints in every sample year. Nevertheless, insofar as costly liquidation reduces debt capacity, high comovement firms would have a greater tendency to face a binding debt capacity constraint. We will see in the next subsection, however, that this effect is probably of secondary importance. The remaining transmission channel from liquidation costs to financially constrained investment for high comovement firms then runs via the premium that these firms pay on external finance due to their reduced ability to pledge assets as collateral.

\subsubsection{Comovement: old wine in new bottles?}

The focus in this chapter is on an understanding of financing constraints as stemming from the way the firm operates in relation to its environment. If our classification on comovement simply sorts out firms that are atypical in terms of leverage, maturity, or growth performance, however, it does nothing more than repeat findings on financing constraints already embodied in results from such firm-level classification schemes. For the remainder of this section, therefore, we explore four firm-level classification schemes that have frequently been considered 
in the literature to identify constrained firms and may also relate to comovement.

Specifically, we have argued that a strong degree of comovement possibly reduces a firm's debt capacity, which makes it more likely for a firm to run into a binding debt capacity constraint. Insofar as high comovement sorts out low leverage firms and vice versa, our findings merely repeat those obtained from a split on leverage. Hence we consider the connection between comovement and leverage. Furthermore, to the extent that young firms perform more volatile relative to mature firms, comovement may also sort firms on the basis of maturity. We have no direct measure of the maturity of the firms in our sample, but assume that mature firms are typically large and retain a relatively small fraction of earnings (i.e. they pay generous dividends). ${ }^{16}$ Lastly, the comovement classification may effectively sort out fast and slow growing firms from the moderately fast growing firms. Hence we also look directly at historical growth performance. ${ }^{17}$

While possibly connected to comovement, these firm-Jevel characteristics differ substantially from comovement in an important methodological point of view: financial ratios such as retention and leverage are easily adjusted in response to unobserved changes in investment opportunities. To a lesser extent this may allso apply to firm size and sales growth (through for instance divestitures and mergers). The empirical observation that the investment of constrained firms displays excess sensitivity to cash flow can then be explained by differences in the measurement error of investment opportunities for constrained and unconstrained firms (see Hoshi et al., 1991; Gilchrist and Himmelberg, 1998). We resolve this problem by separating a classification from an estimation period. Furthermore, we define a relatively long classification period (1983-1991) to ensure that we classify firms as constrained only when this is a more or less structural status. ${ }^{18}$ This increases the likelihood that these firms remain constrained for the main part of the estimation period, 1992-1996.

In table 3.3 we compare the selection of constrained firms on the basis of retention practice, size, growth, and leverage in comparison to the classification on the basis of comovement. Panel A of the table shows the distribution of firms

16 See footnote 12 above for studies on size and maturity in relation to financing constraints. The notion that high retention firms are more likely to face binding financing constraints is well-established. See for instance Fazzari et al (1988), Oliner and Rudebusch (1992), Hubbard et al. (1995), Elston (1996), Bond and Meghir (1994), Vari Ees et al. (1998), to name just a few.

17 Hubbard and Kashyap (1992), Elston (1998), and Van Ees et ai. (1997) all associate financing constraints with poor growth performance.

18 Alternatively, we may fail to observe innovations in investment opportunities on a structural basis. However, in that case the firm-specific effects will pick them up. 
Table 3.3

What comovement does not proxy for

\begin{tabular}{|c|c|c|c|c|c|}
\hline \multicolumn{6}{|c|}{ PANEL A ALTERNATIVE CLASSIFICATIONS OF FIRMS' } \\
\hline & Comovement & Retention & Silize & Growth & Leverage \\
\hline \multirow{2}{*}{\multicolumn{2}{|c|}{$\begin{array}{ll}\text { Low/Small } & 48 \\
\text { Medium } & 96\end{array}$}} & & & 51 & \\
\hline & & 119 & 461 & & 154 \\
\hline \multicolumn{2}{|c|}{ High/Large } & 82 & 45 & 51 & 52 \\
\hline Total & 192 & 201 & 206 & 206 & 206 \\
\hline \multicolumn{6}{|c|}{ PANEL B THE RELATIONSHIPS AMONG ALTERNATIVE CLASSIFICATIONS ${ }^{2}$} \\
\hline & Comovement & Retention & Size & Growth & Leverage \\
\hline Comovement & & $\begin{array}{l}x^{2}(2)= \\
2.064\end{array}$ & $\begin{array}{r}\chi^{2}(2)= \\
0.093\end{array}$ & $\begin{array}{r}x^{2}(4)= \\
3.049\end{array}$ & $\begin{array}{l}x^{2}(2)= \\
3.370\end{array}$ \\
\hline Retention & 0.054 & & $\begin{array}{r}x^{2}(1)= \\
4.689\end{array}$ & $\begin{array}{r}\chi^{2}(2)= \\
3.814\end{array}$ & $\begin{array}{c}\chi^{2}(1)= \\
16.116^{\circ *}\end{array}$ \\
\hline Size & 0.018 & $-0.153^{*}$ & & $\begin{array}{l}\chi^{2}(2)= \\
4.152\end{array}$ & $\begin{array}{c}\chi^{2}(1)= \\
1.997\end{array}$ \\
\hline Growth & -0.093 & -0.055 & -0.100 & & $\begin{array}{l}\chi^{2}(2)= \\
5.297\end{array}$ \\
\hline Leverage & -0.017 & $0.283^{* 4}$ & 0.098 & $-0.143^{*}$ & \\
\hline
\end{tabular}

$1 \quad$ All classification schemes use the 1983-1991 period. Comovement is low, medium, and high as defined before. Retention is high if the firm paid out less than ten percent or earnings in dividends in 6 years or more. A firm is large when the value of its assets is above the $75^{\text {th }}$ percentile of the total assets distribution of its 2-digit SBI93 sector for 6 years or more. A firm's growth rate is low (high) when its average annual sales growth rate is below (above) the $25^{\text {th }}$ ( $\left(75^{\text {th }}\right.$ ) percentile of the sample. Leverage is high when the firm's average leverage ratio is above the $75^{\text {th }}$ percentile of the sample.

2 Independence is assessed using a non-parametric goodness-of-fit test based on the differences between observed and expected classification frequencies: the upper-right triangle reports the concomitant $\chi^{2}$ test statistics. The lower-left triangle reports the simple correlation coefficient between two classification criteria. Significance at the 5 and 1 percent error level is indicated by " and "

across constrained and unconstrained classes. ${ }^{19}$ We note that the size classification

19 Retention practice could not be determined for 5 firms as they had not issued shares for a meaningful part of the classification period. Also, Fazzani et al. (1988) consider separate low and medium retention classes and we do not. We cannot construct a medium 
very effectively sorts out the 45 largest Dutch firms: the average value of total assets for large firms in 1991 was NLG 2,974 million, as compared to NLG 196 million for the other firms. ${ }^{20}$ This reflects the structure of the Dutch corporate sector well, with a small group of very large multinationals. It also likely sorts out the most mature firms, who have access to external finance not only through Dutch, but also through international capital markets. For completeness, we remark that the 51 fast growing firms exhibited an average annual sales growth rate for the period 1983-1991 of 12.6\%; the 104 moderately fast growing firms grew at an average $5.2 \%$, and; the 51 firms slow growing firms contracted annually by $3.3 \%$. Lastly, the 52 highly leveraged firms have an average debt to assets ratio of 0.65 . For the remaining 154 firms, the corresponding figure is $0.44 .^{21}$ Panel $B$ subsequently shows the association between the alternative classification schemes. The top-right triangle tests whether the distribution of firms across constrained and unconstrained classes is independent for any pair of classification schemes. The bottom left triangle correlates the status of a firm in any two classification schemes. From the first row we read that independence of the comovement classification and any one of the alternative classifications cannot be rejected at conventional levels of confidence. At the same time, however, there is (very) weak evidence that comovement and leverage classifications are dependent: independence is accepted with a p-value of $19 \%$, which is by far the lowest in this first row. Also, from the bottom left part of the table, we read that the correlation between comovement and leverage is negative, suggesting that the direction of this weak connection is in line with our theoretical conjecture: high comovement increases the probability of binding debt capacity constraints. ${ }^{22}$ The correlations are considerably higher and statistically more meaningful among the firm-specific classifications; however: firms that retain a relatively small fraction of earnings are typically large and have

retention class because only 10 firms satisfy the criterium (i.e. retention rates of $80-90 \%$ ) and widening this medium class (to retention rates of $75-90 \%$ and even $70-90 \%$ ) did not solve this problem sufficiently. For size and leverage, separate low and medium classes were identified, but merged on the basis of initial estimation results.

20 The size differentials were much more moderate among the remaining 161 firms. Nevertheless, we checked for differential investment-cash flow sensitivity also between small and medium-sized firms and found none.

21 While there are still substantial differences in leverage ratios among the low leverage firms, we found no evidence that firms with particularly low leverage ratios displayed a particularly low investment-cash flow sensitivity.

22 Capital structure is determined by many factors (see for instance Harris and Raviv, 1991) and costly liquidation is apparently not a dominant factor in our sample. 
low leverage ratios; fast growing firms tend to be smaller and they usually also have low leverage ratios.

\subsubsection{Alternative classifications and financing constraints}

We dismiss sample specificity as an explanation of our innovative findings on the connection between sales comovement and financing constraints. Specifically, we also apply the well-known firm-level classification schemes to our empirical investment equation and report the estimation results in table 3.4. The estimated parameters on lagged investment, sales growth, and the sales-to-assets ratio are broadly in line with those obtained and discussed before. More importantly, we find investment-cash flow sensitivity patterns that are very much in line with findings well-documented in the literature. In particular, we find that investment of high retention firms is most sensitive to cash flow. The observation from table 3.3 that these firms are typically small and have high leverage ratios as well is reflected in the observation that the investment of small firms and heavily indebted firms is most sensitive to cash flow. This strongly suggests that retention practice, leverage and size would be close contenders in pointing out the presence of a common, unobservable factor in a multiple discriminant analysis: they tend to sort out mature firms characterised by low retention and leverage rates and a large size.

The excess sensitivity results for growth are not so easily explained, however. On the one hand we find the familiar result that investment of slow growing firms is more sensitive to cash flow, but on the other hand we find the same result for fast growing firms. A closer look at the classification data learns that among the slow growing firms, there are relatively more firms that are heavily indebted than firms that are large, so that the constraining effect of high leverage dominates in this tail of the growth distribution. Among the fast growing firms, there are relatively many small firms compared to low debt firms, which suggests that the financing constraints associated with these firms mainly reflect their average size (and not their relatively low leverage ratios).

The main insight of this exploration of firm-specific classification schemes is the following. The firm-level classifications that we consider are associated with excess sensitivity in much the same way as is documented in the literature. Thus sample specificity is not an issue. Furthermore, the previous subsection told us that these firm-level classifications also share some of their informational content on financing constraints in the sense that they tend to sort similar types of firms in many instances. But they do not sort out the same firms as we have done above using firm-industry sales comovement. Hence the excess sensitivity results obtained from the comovement classification do not reproduce findings obtained with other, firm-level classifications, are not attributable to sample specificity, and therefore provide new insights regarding the working of financing constraints. 


\section{Table 3.4}

Alternative classifications and financing constraints: 1992-1996

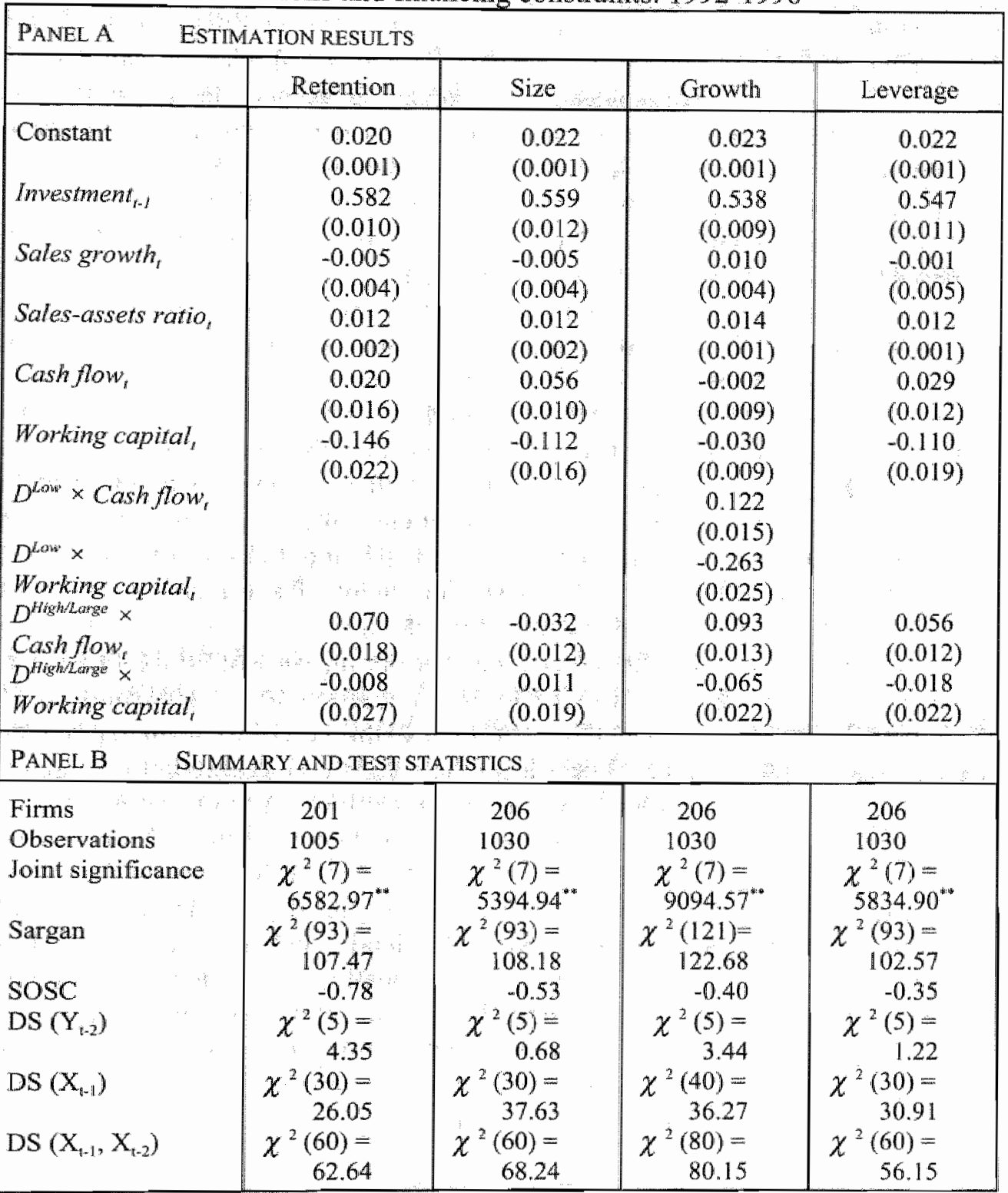

Notes: Random effects estimates of Imestment $t_{i}$ defined as changes in tangible fixed assets due to purchase or production over total assets. Standard errors are robust to heteroskedasticity (cf. White, 1982) and reported in parentheses. See table 3.3 for the definition of the respective dummies and table 3.1 for that of all other variables. The instrument sets consist of Imvesment lagged two and three periods and all other variables (including interaction terms) lagged one, two, and three periods. See table 3.2 for the interpretation of summary and test statistics. 


\subsection{Summary and conclusions}

Liquidation is costly and the incidence of these costs may be reflected in a firm"s investment decision. In this chapter; we have demonstrated that liquidation costs - measured by firm-industry sales comovement - influence the sensitivity of a firm's investment decision to financial factors. In particular, in the empirical evaluation of the investment equation high liquidation costs are associated with excess sensitivity of corporate investment to financial variables: the cash flow sensitivity of investment is lowest for firms with relatively weak comovement and highest for firms with relatively strong comovement.

We have argued that liquidation costs may have an impact on the interdependence of finance and investment through an increase in the cost of borrowing and possibly through a reduced debt capacity as well as. Both channels run via the depressing effect that costly liquidation has on the value of a firm's assets as collateral to loans. However, we find that the evidence for the debt capacity channel is weak. More precisely, firms with particularly low comovement - those that we expect to have the highest debt capacities - are not the firms we also classify as highly leveraged. Hence costly liquidation influences the connection between finance and investment mainly by increasing a firm's dependence on uncollateralised and expensive debt.

Using firm-industry sales comovement as our measure of liquidation costs, we emphasise the way the firm performs in relation to its environment in explaining the working of financing constraints. In this regard we want to point out that classification schemes using firm-level characteristic such as retention practice and size - although they associate with excess sensitivity patterns in a way that is in line with the literature - do not associate with our classification on comovement. This is true even though amongst themselves, these classifications on firm-level characteristics tell more or less the same story: it is typically the mature firm - the one that has grown large, pays generous dividendls, and has a relatively low leverage ratio - that decides on investment mostly independent of financial considerations. Comovement therefore adds new insights regarding the working of financing constraints: it is the way the firm performs relative to its environment that importantly drives the dependence of investment on finance by making liquidation, and concomitantly external finance, costly. 


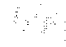

औ 


\section{Appendix: Measuring firm-industry sales comovement}

We consider the following sectors (sectors 20-39 in the SBI74 classification): Food and goodies (20/21), Textile (22), Clothing (23), Leather, shoes, and leatherware (24), Wood and furniture (25), Paper and related (26), Graphic industry and publishers (27), Petroleum (28), Chemical (29), Synthetic strings and fibres (30), Rubber and synthetics processing (31), Building materials, pottery, glass (32), Basic metal (33), Metal products (34), Machines (35), Electronics (36), Transports (37), (Optical) instruments (38), and Other (39). The sector sales data at the twodigit SBI74 level can be found in "Samenvattend overzicht van de industrie, K160 ". Price information is confidential.

We cannot compute our measure of comovement for firms in sectors 27 and 38 as price indices are not available for these sectors and hence sales cannot be deflated. Fourteen firms are in these two sectors. In addition, sales data are not available for sectors 20 and 21 separately, but only for both sectors jointly. Therefore, we deflate these combined sector-sales with the average price index of the two sectors and treat these two sectors as a single one. The correlation of the price indices of the individual sectors is nearly 90 percent in levels and 70 percent in growth rates. Therefore, the loss in accuracy using the aggregate deflator is probably not large. For sectors 29 and 30 sales are likewise not reported for the sectors separately but only for the two sectors jointly. Moreover, the price index for sector 30 is unavailable as well. Since approximately ten percent of our sample consists of firms in sector 29 (but none in sector 30), we are reluctant to eliminate these observations. Instead, we deflate the combined sales of sectors 29 and 30 with the price index for sector 29. Our estimation results are not affected by excluding sectors 29 and 30 . 


\section{Chapter 4 \\ Internal Capital Markets in Dutch Firms}

\subsection{Introduction}

In the previous two chapters we discussed the fact that a firm may face difficulties in obtaining the required amount of funds to finance planned investment due to information problems and agency costs. In such instances the availability of internal financial resources, rather than expected profitability, becomes a driving force of investment (Fazzari, Hubbard, and Petersen, 1988). In this chapter, we develop the argument that firms create organisational structures to deal with such financial issues. In particular, internal capital markets in which various segments pool their financial resources allow headquarters to direct funds to the most profitable projects (Stein, 1997). Various studies provide evidence of the presence of internal capital markets. Lamont (1997) investigates firms having segments in both the oil and non-oil industry around the 1986 oil price shock. He shows that in 1985 some non-oil segments were subsidised by oil segments. These subsidised segments cut back investment sharply in 1986 when oil cash flow dwindled. Further evidence suggesting the existence of internal capital markets is found by Shin and Stulz (1998) who show that a segment's investment is affected by cash income generated by the other segments belonging to the same firm.

In this chapter we investigate the use of the internal capital market in the Dutch corporate sector in three different settings.' First, in line with Shin and Stulz (1998) we investigate the functioning of internal capital markets for diversified and undiversified firms. Using a data set on the finances of Dutch firms and the segments of which they consist covering the period 1995-1998, we analyse whether firms redistribute financial resources among different

1 Our focus on the use of internal capital markets by firms does not automatically imply that we assume them efficient as well. Scharfstein and Stein (2000) and Shin and Stulz (1998) provide theoretical arguments and empirical evidence, respectively, suggesting that firms may use internal relocation of funds to keep the disciplining forces of the capital markets at arm's length. This may lead to overinvestment in underperforming segments, for example. In such instances, while corporate management benefits from the internal capital market, shareholders do not. We recognise this dark side of internal capital markets, but do not discuss the topic of efficiency in this chapter. Instead, we emphasise the benefits for firms and argue that they have incentives to actively re-allocate funds across segments. 
segments. We distinguish between diversified and undiversified firms, because diversification may enhance the ability to redistribute financial resources. Apart from Shin and Park (1999), who analyse Korean 'Chaebols', all other studies focussing on this issue employ US data. Hence, this chapter provides some insight whether previous results can be generalised towards firms operating in the Netherlands.

Secondly, Hoshi, Kashyap, and Scharfstein (1991) show that the presence of a large bank in Japanese Keiretsu alleviates financing constraints for the participating firms. Furthermore, Van Ees and Garretsen (1994) show for a sample of Dutch firms that financing constraints at the firm-level are associated with corporate ties to banks. We check wether internal capital markets function differently for firms that house a financial segment than for firms that do not. The conjecture in this case is that firm funds may be better distributed over the available segments and concomitant investment projects through the presence of a financial segment. Such a segment is for instance a financial holding company that directs internal funds to the investment projects it deems most valuable to the firm.

Thirdly, it may be argued that the internal capital market is most valuable when the firm experiences some form of financial stress. Therefore, Peyer and Shivdasani (2001) focus on the functioning of the internal reallocation of funds under exactly such stress scenarios. Specifically, their analysis examines the working of the internal capital market before and after a leveraged recapitalisation. Peyer and Shivdasani show that increased leverage may have a detrimental impact on the working of internal capital markets. In particular, it seems to have the effect of shifting emphasis away from investment in projects with growth opportunities and towards investment in projects that generate cash on a relatively short-term basis. The suggestion of these findings is that internal capital markets were working before the recapitalisation to the extent that funds were being reallocated between segments. After the recapitalisation, however, the increased debt burden detaches the financing connections between segments as each segment is now solely focussed on generating cash. This result can have important policy relevance in a bank based system such as the Netherlands. However, Peyer and Shivdasani's (2001) results may be driven to a large extent by the specific sample used so that their results cannot readily be generalised. Specifically, the authors note that most of the firms they analyse may have conducted the leveraged recapitalisation as a response to some form of external pressure (most notably a take-over threat). To the extent that leverage was increased to levels well above targets, firms may have stressed short-term cash flow generation to consecutively reduce leverage back to normal. The observed absence of the internal capital market then not only reflects the heavy debt burden, but also the desire to reduce leverage fast. We attempt to generalise 
Peyer and Shivdasani's findings regarding the effects of the debt burden on the functioning of internal capital markets. We therefore focus on firms that are characterised by a historically and structurally heavy (or light) debt burden, rather than on firms experiencing some (externally induced) shock to leverage that they want to nullify. The firms we analyse are therefore less likely to be inclined to reduce the debt burden fast by directing investment to quick cash projects.

The plan of the chapter is as follows. Section 4.2 reviews the empirical model we estimate to investigate the presence of internal capital markets. In section 4.3 we present results regarding firm diversification and the functioning of internal capital markets and in section 4.4 we investigate the role of financial segments. In section 4.5 we discuss the impact of the debt burden. We conclude and provide some directions for further research in section 4.6 .

\subsection{The empirical investment equation}

The purpose of the present analysis is to investigate whether internal capital markets are actively used within Dutch firms. The incentive to reallocate funds internally stems from the sources that make external finance more expensive than internally available funds, as discussed extensively in chapters 2 and 3 . In line with these chapters, we therefore expect segment investment to depend on financial considerations. By focussing on the presence or absence of redistribution of funds across segments within a firm, we specifically ask whether and in which instances particular firms reallocate financial resources between different segments using the internal capital market. Put differently, we want to stress the origination of the financial factors that impact on segment investment. Regarding the measurement of financial interdependencies between segments we stress the sensitivity of segment investment to other segments" funds. To that end we follow Shin and Stulz (1998) and regress a segment's investment rate on the segment's own cash flow as well as on the aggregate cash flow of the other segments that are part of the same firm (for the remainder of the analysis we will simply refer to this as "other cash flow"). Sensitivity of segment investment to other cash flow is the main piece of evidence for active internal reallocation of funds, i.e. for the presence and active use of internal capital markets. We do not have sufficient information to construct Tobin's $Q$ at the segment level, which is usually employed in empirical investment equations to proxy for investment opportunities. Instead, we include the sales growth rate 
as an indicator for investment opportunities. ${ }^{2}$ Hence our segment-level investment equation is of the sales-accelerator type we also used in the previous chapter:

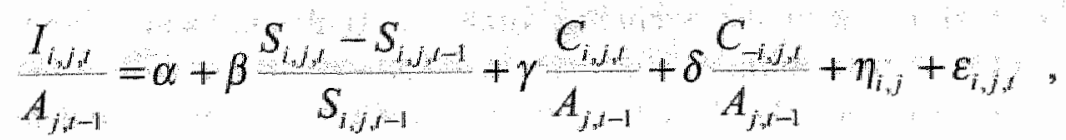

where $I_{i, j, t}$ denotes gross investment of the $i^{\text {th }}$ segment of firm $j$ during year $t_{\text {, }}$ $A_{j,-1}$ is the book value of total assets of firm $j$ at the end of year $t-l$ and $S_{i, j, k}$ measures sales of segment $i$ of firm $j$ during year $t . C_{i, j, t}$ stands for cash flow of segment $i$ of firm $j$ in year $t$ and $C_{-i, j, t}$ indicates the sum of cash flows from all segments of firm $j$ in year $t$ excluding the cash flow of segment $i$ of firm $j$. We estimate the investment equation depicted above using fixed effects where $\eta_{i, j}$ accounts for unobserved segment heterogeneity (including in this specific instance the omitted additional information on segments' profit opportunities). $\varepsilon_{i, j, t}$ is a white-noise error term with the usual properties. ${ }^{3}$

The variables we need for our analysis are investment, sales growth, and cash flow measured at the segment level. At the firm level we need total assets to deflate segment investment and cash flow in the estimation of our equation (4.1). We measure investment as gross investment in tangible fixed assets, sales is measured as earnings from market sales of goods and services supplied to third parties, and cash flow is earnings after interest, but before depreciation, dividends, and taxes. ${ }^{4}$ Furthermore, we need a measure of firm cash flow from which we can subtract segment cash flow so that we measure $C_{-i, f,}$. Firm cash flow can be constructed in two different ways. Strategy 1 is that we measure cash flow as reported by the firm and strategy 2 is that we add the cash flows of all the segments that constitute the firm. Ideally the difference between the two strategies should be trivial. In the composite database that we use, however, we have two particular problems. First, we have non-response at both the segment and the firm level. This implies that the sum of segment cash flows is not equal to firm cash flow if information on one or more segments is missing. Second, cash flow measured at the firm and segment level does not have the exact same interpretation. In particular, cash flow is measured as earnings after interest where earnings refers to sales of goods and services to third parties. Hence

3 This indicator results for instance from a neo-classical specification of investment with costly adjustment and omission of factor prices (cf. section 2.2.3).

We find that the inclusion of year dummies does not affect the results we present in later sections and we therefore do not include them here.

4. At the segment level taxes are not recorded. Hence no after-tax measure of earnings is available. 
segment cash flow includes revenues from sales to other segments, while firm cash flow excludes such intra firm transactions. In our analysis we have therefore opted for strategy 2 for two reasons. First, we want to give cash flow the same interpretation, regardless of whether we are talking about firm cash flow or segment cash flow. Second, given the stratified sampling design of the segment level data, we know that the mismeasurement of firm cash flow as the sum of segments' cash flows is limited since missing observations are concentrated among the smaller segments (see the data appendix). ${ }^{5}$ Firm cash flow in our analysis is therefore the sum of all reported cash flows of all the segments that belong to the same firm. "Other cash flow" excludes the segments' own cash flow from this measure. We estimate equation (4.1) for the period 1996-1998. Descriptive statistics for all variables are presented in table 4.1.

\section{Table 4.1}

Description of variables for the 1996-1998 MICRONOOM sample

\begin{tabular}{|l|c|c|c|c|c|c|}
\hline & Mean & $\begin{array}{c}\text { Standard } \\
\text { deviation }\end{array}$ & $\begin{array}{c}10^{\text {th }} \\
\text { percentile }\end{array}$ & Median & percentile & Segments \\
\hline Investment & 0.017 & 0.045 & 0.000 & 0.003 & 0.044 & 10005 \\
Sales growth & 0.067 & 0.198 & -0.143 & 0.051 & 0.285 & 10005 \\
Own cash flow & 0.037 & 0.068 & -0.000 & 0.012 & 0.122 & 10005 \\
Other cash flow & 0.102 & 0.110 & -0.001 & 0.096 & 0.222 & 10005 \\
\hline
\end{tabular}

Notes: Investment is measured as segment gross investment in tangible fixed assets; sales is measured as segment earnings from market sales of goods and services supplied to third parties; own cash flow is segment earnings after interest, but before depreciation, dividends, and taxes; other cash flow is the sum of segment cash flow within a firm, excluding segment"s own cash flow. Investment, own cash flow, and other cash flow are deftated by the book walue of end-of-previous-period total firm assets.

\subsection{Firm diversification}

As indicated above, the importance of optimal internal distribution of funds across segments of a particular firm stems from the same sources discussed in

5 We have also computed - but do not report - all the results we present later on for restricted samples where we require $50 \%$ and $75 \%$ of the total number of non-financial segments of the firm to be observed and included in the analysis. Approximately half of the firm-years in our sample meet the $50 \%$ coverage criterion, only one in ten meet the $75 \%$ criterion. The qualitative results obtained from these restricted samples are the same as those reported in the tables for the full sample. Hence we have no reason to believe that missing observations lead to biases in the measurement of $C_{-i, j}$ 
chapters 2 and 3 that reduce the ability of the firm to access low cost external finance easily and make investment and finance non-separable. Given costly or unavailable external finance, the limited pool of internal funds must be directed towards the most profitable uses, regardless of their segment of origination within the firm. ${ }^{6}$ Put differently, it is the presence of binding financing constraints at the firm level that makes the efficient working of the internal capital market important. Within such a setup, some firms may be better equipped to use the internal capital market than others.

Consider a firm that faces binding financing constraints and efficiently deploys the internal capital market to make the best use of the limited pool of available funds. Now assume that this firm is well-diversified. In this instance, a rise or fall in the cash flow of one of its segments should not lead to a proportionate reduction in the investment of this particular segment. Segment investment should be maintained after such a change in segment cash flow so long as segment investment opportunities relative to those of the other segments remain unaltered. ${ }^{7}$ Hence, the optimal rate of investment of a single segment within a diversified firm should be maintained after a fall in segment cash flow by redirecting funds generated elsewhere in the firm towards this segment. The empirical prediction is therefore that in this setup segment investment is sensitive to firm cash flow, not a segment's own cash flow. ${ }^{8}$ Assume, alternatively, that the firm we are looking at is undiversified. In this scenario, a shock to cash flow of any segment is likely to be correlated with changes in firm cash flow. A segment that would have had to cut back investment after a negative shock to cash flow in a hypothetical stand alone situation is likely to have to do this also when it is part of an undiversified firm.

Comparing diversified to undiversified firms, it thus appears that the scope for the internal capital market is larger for the former than for the latter type of firm. In estimating our equation (4.1), then, we expect segment investment for

- Alternatively, for the financing of unprofitable pet projects for which external finance cannot be obtained, internal sources must be arranged. This illustrates that the optimal use of the internal capital market by the firm may not be valuable from the point of view of the shareholders.

Save for the effect that this fall in segment cash flow has on firm cash flow.

* Of course, in the empirical analysis, segment cash flow may embody information regarding the relative profitability of the segment. Mismeasurement of investment opportumities therefore allows segment investment to be sensitive to segment cash flow even when internal capital markets are efficiently used. This argument is directly related to the interpretation of the sensitivity of firm investment on firm cash flow, discussed in section 2.3 .2 . 
diversified firms to be more strongly related to firm cash flow than segment investment of undiversified firms and less so to a segment's own cash flow. Additionally, as Shin and Stulz (1998) remark, the investment rate of the small segments is probably easier to maintain/subsidise than the investment rate of the large segments after a fall in segment cash flow. We check this conjecture by estimating segment investment equations for the smallest and largest segments of moderately and highly diversified firms separately. ${ }^{9}$

Table 4.2 presents regression results for segment investment equations within moderately and highly diversified firms. Diversification is defined in two different ways. In panel $\mathrm{A}$, firms are divided into moderately and highly diversified based on the count of the number of segments that constitute the firm. ${ }^{10}$ In panel $\mathrm{B}$, the division is based on the count of the number of 2-digit activities in which the segments that constitute the firm are active.

From the estimates for all segments (columns 1 and 2) in panels A and B alike we observe that own cash flow is the single driving force of segment investment. Additionally, the sensitivity of segment investment to own cash flow is higher, not lower, if the segment is part of a diversified firm. The difference in the sensitivity to own cash flow between moderately and highly diversified firms is statistically and economically significant in the panel B estimates. These findings are at odds with our theoretical conjectures. Regarding the sensitivity of segment investment to other cash flow, the findings in the first two columns of panels A and B suggest that there is little evidence of actively exploited internal capital markets in Dutch firms. Note, however, that segments of diversified firms tend to be more sensitive to other cash flow. This differential, however, is only marginally significant between segments of a firm with less than five segments as compared to firms with five segments or more and insignificant when we define diversification in terms of economic activities.

Accommodating the possibility that internal capital markets have a different meaning for small and large segments, columns 3 to 6 present estimated segment investment equations for the smallest and largest segments of each firm separately. The positive observation from this exercise is that the patterns of own as well as other cash flow sensitivities point in the right direction in three out of four instances. That is to say, segments of moderately diversified firms exhibit, on average, a stronger sensitivity to own cash flow and a weaker sensitivity to other cash flow while the opposite holds for segments of

9. Since we do not observe total assets at the segment lewel, smallest and largest segments are identified according to sales.

10 Firms consisting of only one segment were removed from the data since the focus is on inter segment reallocation of funds. 
highly diversified firms. In panel A we observe that the sensitivity to own cash flow is positive and significantly different from zero for the smallest segments of moderately diversified firms, but insignificantly different from zero for the smallest segments of highly diversified firms; for the largest segments we observe that segment investment is significantly and positively sensitive to other cash flow within highly diversified firms, but not within undiversified firms. In panel $B$ we observe a significant and positive sensitivity of the large segments: investment to own cash flow within moderately diversified firms, but not within highly diversified firms.

\section{Table 4.2}

Segment investment for (un)diversified firms

\begin{tabular}{|c|c|c|c|c|c|c|}
\hline \multicolumn{7}{|c|}{ PANEL A: FIRMS CHARACTERISED BY NUMBER OF SEGMENTS } \\
\hline \multirow[b]{2}{*}{ Count of segments } & \multicolumn{2}{|c|}{ All segments } & \multicolumn{2}{|c|}{$\begin{array}{l}\text { Largest segments } \\
\text { only }\end{array}$} & \multicolumn{2}{|c|}{$\begin{array}{c}\text { Smallest segments } \\
\text { only }\end{array}$} \\
\hline & $2-4$ & $5+$ & $2-4$ & $5+$ & $2-4$ & $5+$ \\
\hline \multirow{2}{*}{ Sales growth } & 0.003 & -0.002 & -0.010 & 0.005 & -0.007 & -0.013 \\
\hline & $(0.011)$ & $(0.002)$ & $(0.024)$ & $(0.008)$ & $(0.007)$ & $(0.008)$ \\
\hline \multirow[t]{2}{*}{ Own cash fllow } & 0.090 & 0.110 & 0.084 & 0.073 & 0.099 & -0.016 \\
\hline & $(0.035)$ & $(0.019)$ & $(0.059)$ & $(0.037)$ & $(0,039)$ & $(0.116)$ \\
\hline \multirow[t]{2}{*}{ Other cash flow } & -0.003 & 0.010 & -0.039 & 0.105 & -0.001 & 0.039 \\
\hline & $(0,041)$ & $(0.007)$ & $(0.082)$ & $(0.033)$ & $(0,020)$ & $(0.031)$ \\
\hline \multirow{2}{*}{$\begin{array}{l}\operatorname{Adj}-R^{2} \\
N\end{array}$} & 0.096 & 0.154 & 0.042 & 0.041 & 0.098 & 0.000 \\
\hline & 2366 & 7639 & 516 & 1429 & 516 & $\quad 1429$ \\
\hline \multicolumn{7}{|c|}{ PANEL B: FIRMS CHARACTERISED BY NUMBER OF ECONOMIC ACTIVTTIES } \\
\hline \multirow{2}{*}{ Count of activities } & \multicolumn{2}{|c|}{ All segments } & \multicolumn{2}{|c|}{ Largest segments } & \multicolumn{2}{|c|}{ Smallest segments } \\
\hline & $1-4$ & $5+$ & 1.4 & $5+$ & $1-4$ & $5+$ \\
\hline \multirow[t]{2}{*}{ Sales growth } & 0.000 & -0.002 & 0.007 & -0.010 & -0.016 & -0.002 \\
\hline & $(0.004)$ & $(0.002)$ & $(0.009)$ & $(0.013)$ & $(0.008)$ & $(0.002)$ \\
\hline \multirow[t]{2}{*}{ Own cash flow } & 0.095 & 0.260 & 0.074 & 0.033 & 0.044 & 0.013 \\
\hline & $(0.021)$ & $(0.028)$ & $(0.034)$ & $(0.078)$ & $(0,062)$ & $(0.078)$ \\
\hline \multirow[t]{2}{*}{ Other cash flow } & 0.001 & 0.004 & 0.019 & 0.057 & 0.038 & -0.011 \\
\hline & $(0.016)$ & $(0.006)$ & $(0.040)$ & $(0.045)$ & $(0.026)$ & $(0.010)$ \\
\hline$A d j-R^{2}$ & 0.144 & 0.239 & 0.088 & 0.054 & 0.007 & 0.003 \\
\hline$N$ & 6866 & 3139 & 1543 & 402 & 1543 & 402 \\
\hline
\end{tabular}

Notes: the dependent variable is segment investment as defined in table 4.1. All other variables are also defined as in table 4.1. Standard errors are in parentheses. 
The overall evidence for active inter segment redistribution of funds across segment is rather weak, a finding that is not in harmony with results presented by Shin and Stulz (1998) for US conglomerates. Noteworthy is also the finding that sales growth fails to contribute to the explanation of segment investment in an economically and statistically significant way. "Additionally, discriminating the importance of internal capital markets for small and large segments, our findings suggest that large, rather than small, segments benefit most from intrafirm reallocation of funds.

The findings so far do not necessarily imply that the potential benefits of the internal capital market are left unexploited in all Dutch firms, however. In particular, a subset of firms may still actively redistribute funds across segments. We attempt to characterise these firms in the next section by exploring the connection between organisational structure and internal capital markets. Moreover, insofar as we fail to observe active use of internal capital markets in the representative firm, we stress the short sample period and the fact that the years we analyse can be characterised by good general economic conditions. This may work against finding active internal capital markets. ${ }^{12}$ Put differently, the short length of the panel and the good economic credit climate probably create a very conservative test for the presence of internal capital markets in this analysis compared to that of for instance Shin and Stulz (1998).

\subsection{Presence of a financial segment}

Firms may be able to distribute funds over the available segments and concomitant investment projects more efficiently through the presence of a

11. We ran all the regressions including the lagged rather than the contemporary sales growth rate. We obtain similar patterns in parameter estimates from this alternative specification, although the considerable reduction in the number of data points, due to the increased use of lagged variables, reduces the statistical significance of the individual parameter estimates in some instances. Instead of using the sales growth variable at the segment level, we employed the contemporaneous and lagged sales growth at the corresponding two digit sector level as well. Again the results are broadly similar. Also note that we have used these alternative specifications for the regressions discussed later in sections 4.4 and 4.5 . In all instances, the quallitative results are broadly similar to the findings reported using contemporary segment sales growth.

12 As noted before, the incentive to reallocate funds within the firm stems from binding financing constraints at the firm level. If we allow these constraints to be weak or absent for the sample years under analysis, then the incentive for making effective use of the internal capital market disappears. Van Ees, Kuper, and Sterken (1997) in fact conclude that access to these external markets is relatively easy in periods of economic prosperity. 
financial segment, such as a financial holding company that directs internal funds to the most profitable uses. In Stein (1997) and Scharfstein and Stein (2000), for example, the theoretical characterisation of the organisational structure of the firm is that of a corporate headquarters that controls the finances of the firm and determines which segments receive funds for investment. However, not all firms have such a specific organisational structure. In fact, only about 20 percent of the firms in our sample contain a holding company. Hence we conjecture that those firms that dlo have a holding company are better equipped to coordinate the finances of its segments and reap the benefits of an internal capital market. To illustrate this impact, consider the large Dutch capital goods producer Stork that incorporates a financial holding in its organisational structure. ${ }^{13}$ From the Stork 1995 annual report we read that one of the priority areas concerns 'exploiting the synergy potential within and between Strategic Business Units. This can be interpreted as: making better use of the internal Stork market' (p. 9). The internal capital market that is employed as such is meant to create 'financial synergy.' In management sciences this vocabulary is used to refer to companies sharing and leveraging financial resources (e.g., De Wit and Meyer, 1998, chapter 6).

Firm-level research has indicated that financial institutions acting as corporate "house-banks" may also alleviate financing constraints. Hoshi et al. (1991) find for a sample of Japanese firms that the presence of a large bank in Keiretsu diminishes financing constraints for the participating firms relative to independent firms. Van Ees and Garretsen (1994), analysing Dutch data, also conclude that close ties to banks reduce the incidence of financing constraints. At the segment level, we might therefore hypothesise that segments clustered around a 'near-bank' financial segment are better able to pool their funds and therefore operate like an industrial group à la Hoshi et al. (1991). ${ }^{14}$ Consider for illustrative purposes DSM, a Dutch multinational active in the chemical and pharmaceutical sectors. The DSM organisational structure contains a segment in sector 67 , which includes activities related to or for the benefit of financial institutions. We interpret this as a near-bank financial segment for the purpose of our analysis. From DSM's $1995-1998$ annual reports we read that the

1. This information can be obtained from the Dun and Bradstreet files. Note that our data as well as the identity of the firms in our sample is confidential and cannot be used for illustrative purposes. These remanks apply to all further illustrations used in the chapter.

14 To strengthen the connection between this research and Hoshi et al. (1991), it is useful to stress the fact that we are strictly speaking of "a collection of enterprises" when we talk about firms and that we talk about "enterprises" when we talk about segments. See also the discussion of the data in the appendix. 
organisational structure is decentralised with considerable freedom of operation at the segment level. At the same time, however, DSM states that the financing and liquidity management issues are a corporate responsibility, revolving around 'a system of internal bank accounts' and 'cash-pools'. Short-term credit facilities are also arranged at the supra-segment level. This strongly suggests the active employment of an internal capital market.

For both Stork and DSM, we argue that the particular organisational structure that facilitates the use of internal capital markets revolves around the presence of the financial segment. Therefore, in our empirical testing, we focus on the organisational structure of a firm in terms of the presence or absence of such a segment. A financial segment in the empirical analysis is interpreted as any segment with an industry code (SBI93) of 65,66 or 67 . Sector 65 segments in our sample consist mainly of financial holding companies, while sector 67 segments contain activities related to or for the benefit of financial institutions, such as stockbrokers, credit intermediaries, and pension fund managers. ${ }^{15}$ The effect of a sector 65 financial segment is therefore conceivably similar to the Stork organisational structure as well as the presence of the corporate headquarters in Stein's (1997) model. The presence of a sector 67 financial segment might function as some sort of firm-clearing house for segment finances, which follows more the practice at DSM and the intuition in Hoshi et al. (1991), where groups of firms are clustered around a 'house-bank'.

In table 4.3 we present the results of estimating equation (4.1) for segments of firms that do or do not house a financial segment. In panel A of table 4.3 the estimated segment investment equations are presented for all segments as well as for the largest and smallest segments separately. Segments are categorised as belonging to a firm which does or does not house any financial segment(s). ${ }^{16}$ The results in panel A are encouraging regarding the presence of inter-segment reallocation of funds. Although for all segments together we observe that own cash flow is the main determinant of segment investment, for the largest and smallest segments separately there are differences in the sensitivity to own and other cash flow in an economically meaningful way. In particular, we see that the presence of a financial segment within the firm reduces segment's

1.5 Commercial and central banks are also classified in sector 65 , but such institutions do not appear as segments in the firms we analyse. Sector 66 financial segments (those active in insurance and pension fund activities) are identified within 53 firms only, 40 of which also house a sector 65 financiall segment. The isolated effect of the sector 66 segment is therefore difficult to observe.

16. Note that financial segments are not included in our data. We only know whether the firm houses such a segment. Also see the data appendix. 
investment sensitivity to own cash flow while at the same time it increases segment's investment sensitivity to other cash flow.

In panels $B$ and $C$ of the table, we isolate the presence of sector 65 and sector 67 financial segments in the organisational structure, respectively. The results in these panels show that, at the 10 percent significance level or better, segment investment of the smallest and largest segments is sensitive to own cash flow in the absence of one of these financial segments but not in their presence. At the same time segment investment is sensitive to other cash flow in the presence of a sector 65 or 67 financial segment, but not so in their absence. The exception applies to the smallest segments, for which the described pattern is observable, although other cash flow remains insignificant even in the presence of a financial segment. For all segments together, the described patterns in both own cash flow as well as other cash flow are observable when

\section{Table 4.3}

Segment investment for firms with(out) financial segments

\begin{tabular}{|c|c|c|c|c|c|c|}
\hline \multicolumn{7}{|c|}{ PANEL A: FIRMS WITH ANY FINANCIAL SEGMENT ${ }^{1}$} \\
\hline \multirow{2}{*}{$\begin{array}{l}\text { Any financial } \\
\text { segment? }\end{array}$} & \multicolumn{2}{|c|}{ All segments } & \multicolumn{2}{|c|}{ Largest segments } & \multicolumn{2}{|c|}{ Smallest segments } \\
\hline & No & Yes & No & Yes & No & Yes \\
\hline Sales grow & $\begin{array}{c}0.002 \\
(0.004)\end{array}$ & $\begin{array}{l}-0.007 \\
(0.006)\end{array}$ & $\begin{array}{c}0.004 \\
(0.011)\end{array}$ & $\begin{array}{c}0.010 \\
(0.011)\end{array}$ & $\begin{array}{l}-0.001 \\
(0.006)\end{array}$ & $\begin{array}{l}-0.045 \\
(0.022)\end{array}$ \\
\hline \multirow[t]{2}{*}{ Own cash flow } & 0.095 & 0.170 & 0.082 & 0.067 & 0.172 & -0.256 \\
\hline & $(0.019)$ & $(0.046)$ & $(0.039)$ & $(0.055)$ & $(0.050)$ & $(0.299)$ \\
\hline \multirow[t]{2}{*}{ Other cash flow } & -0.004 & 0.028 & 0.011 & 0.219 & -0.006 & 0.142 \\
\hline & $(0.012)$ & $(0.021)$ & $(0.040)$ & $(0.071)$ & $(0.021)$ & $(0.083)$ \\
\hline \multirow{2}{*}{$\begin{array}{l}\text { Adj-R } R^{2} \\
N\end{array}$} & 0.177 & 0.129 & 0.103 & 0.021 & 0.090 & 0.001 \\
\hline & 6828 & 3177 & 1406 & 539 & 1406 & 539 \\
\hline \multicolumn{7}{|c|}{ PANEL B: FIRMS WITH FINANCIAL HOLDING COMPANY ${ }^{2}$} \\
\hline \multirow{2}{*}{ Financial holding? } & \multicolumn{2}{|c|}{ All segments } & \multicolumn{2}{|c|}{ Largest segments } & \multicolumn{2}{|c|}{ Smallest segments } \\
\hline & No & Yes & No & Yes & No & Yes \\
\hline Sales g & $\begin{array}{c}0.003 \\
(0.003)\end{array}$ & $\begin{array}{l}-0.024 \\
(0.009)\end{array}$ & $\begin{array}{c}0.007 \\
(0.010)\end{array}$ & $\begin{array}{l}-0.016 \\
(0.011)\end{array}$ & $\begin{array}{l}-0.000 \\
(0.005)\end{array}$ & $\begin{array}{l}-0.101 \\
(0.041)\end{array}$ \\
\hline \multirow[t]{2}{*}{ Own cash flow } & 0.106 & 0.081 & 0.074 & 0.044 & 0.179 & -0.208 \\
\hline & $(0.019)$ & $(0.058)$ & $(0.038)$ & $(0.041)$ & $(0.047)$ & $(0.626)$ \\
\hline \multirow[t]{2}{*}{ Other cash flow } & -0.003 & 0.052 & 0.008 & 0.297 & -0.005 & 0.143 \\
\hline & $(0.011)$ & $(0.029)$ & $(0.039)$ & $(0.055)$ & $(0.019)$ & $(0.121)$ \\
\hline $\operatorname{Adj}-R^{2}$ & 0.181 & 0.019 & 0.098 & 0.036 & 0.095 & 0.000 \\
\hline $\mathrm{N}$ & 8124 & 1881 & 1592 & 353 & 1592 & 353 \\
\hline
\end{tabular}




\begin{tabular}{|c|c|c|c|c|c|c|}
\hline \multirow{2}{*}{$\begin{array}{l}\text { Related financial } \\
\text { segment? }\end{array}$} & \multicolumn{2}{|c|}{ All segments } & \multicolumn{2}{|c|}{ Largest segments } & \multicolumn{2}{|c|}{ Smallest segments } \\
\hline & No & Yes & No & Yes & No & Yes \\
\hline \multirow[t]{2}{*}{ Sales growth } & -0.000 & -0.007 & -0.000 & 0.025 & -0.002 & -0.072 \\
\hline & $(0.003)$ & $(0.010)$ & $(0.009)$ & $(0.020)$ & $(0.005)$ & $(0.043)$ \\
\hline \multirow[t]{2}{*}{ Own cash flow } & 0.088 & 0.298 & 0.073 & 0.085 & 0.154 & -0.512 \\
\hline & $(0.017)$ & $(0.075)$ & $(0.033)$ & $(0.081)$ & $(0.041)$ & $(0.569)$ \\
\hline \multirow[t]{2}{*}{ Other cash flow } & -0.002 & 0.038 & 0.027 & 0.258 & -0.006 & 0.266 \\
\hline & $(0.010)$ & $(0.031)$ & $(0.034)$ & $(0.110)$ & $(0,016)$ & $(0.180)$ \\
\hline $\operatorname{Adj}-\mathbb{R}^{2}$ & 0.169 & 0.166 & 0.092 & 0.031 & 0.091 & 0.004 \\
\hline $\mathrm{N}$ & 8247 & 1758 & 1686 & 259 & 1686 & 259 \\
\hline
\end{tabular}

Notes: the dependent variable is segment investment as defined in table 4.1. All other variables are also defined as in table 4.1. Standard errors are in parentheses.

1 Does the firm house one or more segments with Dutch industry code (SBI93) 65, 66 or 67 ?

2 Does the firm house one or more segments with Dutch industry code (SBI93) 65 ?

3 Does the firm house one or more segments with Dutch industry code (SB193) 67?

we characterise on the presence of a sector 65 financial segment, but not so when we characterise on the presence of a sector 67 financial segment.

Overall, we conclude from these results that financial segments foster the functioning of internal capital markets in Dutch firms. This finding is new in the internal capital market literature and emphasises the argument that the benefits of internal capital markets in conglomerates are not self-evident. Rather, the findings presented above strongly suggest the need for an adequate organisational structure to harvest the potential benefits. At the same time it is important to realise that the presence of a financial segment does not proxy for a diversified firm, since we concluded from the previous section that the partial impact of diversification on the working of the internal capital market is meagre at best.

\subsection{The weight of the debt burden}

Peyer and Shivdasani (2001) show that high rates of leverage may effectively disrupt the working of the internal capital market. In their investigation of segment investment before and after a leveraged recapitalisation, they observe that segments behave more as stand alone units after the event. Specifically, segment investment is driven more by segment own cash flow and no longer by other cash flow after the increase in leverage. They attribute this finding to the 
distortion of incentives that follows from high rates of leverage which induces firms to focus on the fast generation of cash rather than the careful exploit of (longer-term) profit opportunities. Peyer and Shivdasani note also that a majority of the firms they analyse (18 out of 22) may have conducted the leveraged recapitalisation as a response to some form of external pressure (most notably a take-over threat). To the extent that leverage was increased to levels above desired ranges, firms may have stressed short-term cash flow generation to reduce leverage back to normal. ${ }^{17}$ Hence their observed working of the internal capital market may primarily reflect the desire to reduce leverage fast.

We generalise Peyer and Shivdasani's findings regarding the effects of the debt burden on the functioning of internal capital markets using the following empirical strategy: we use historical firm-level financial data to characterize the firm as carrying a relatively heavy or light debt burden. Hence we focus on firms that are characterised by a historically and structurally heavy (or light) debt burden rather than on firms experiencing some (externally induced) shock to leverage that they want to nullify. The firms that we analyse therefore do not seem to have succumbed to the desire to reduce the debt burden (by directing investment to quick cash projects). Hence the internal capital market effects we analyse stem from the debt burden itself, not the desire to reduce debt. We use information for the 1986-1994 period on firm-level interest coverage ratios (defined as Standard \& Poor's EBITDA interest coverage) to characterise firms at the start of our estimation period as bearing a heavy or light debt burden. We employ three criteria for the weight of the debt burden that differ in strictness. ${ }^{18}$ The first and most lenient criterion classifies a firm as heavily indebted when in a balanced panel of firms observed during the 1992-1994 period - it records only below median interest coverage ratios. ${ }^{19}$ The second criterion further requires the firm - in a balanced panel of firms observed during the 1989-1994

17. In fact, Peyer and Shiwdasani (2001) find that a subset of firms with low coverage ratios that subsequently reduce leverage considerably present the driving force behind the main conclusions of their paper. They also document that mean and median leverage in their sample is rapidly reduced during the first three years after the recapitalisation.

18 We have also assessed the debt burden using historical information on the leverage ratio. This produces qualitatively similar results to those reported later using coverage.

19. The mirror image of these demands identify the lightly indebted firms and the same goes for the stricter criteria. In this case, three above median interest coverage ratios in a balanced panel of firms for 1992-1994 are required for a classification of lightly indebted. 


\section{Figure 4.1}

Median interest coverage for three balanced panels of firms

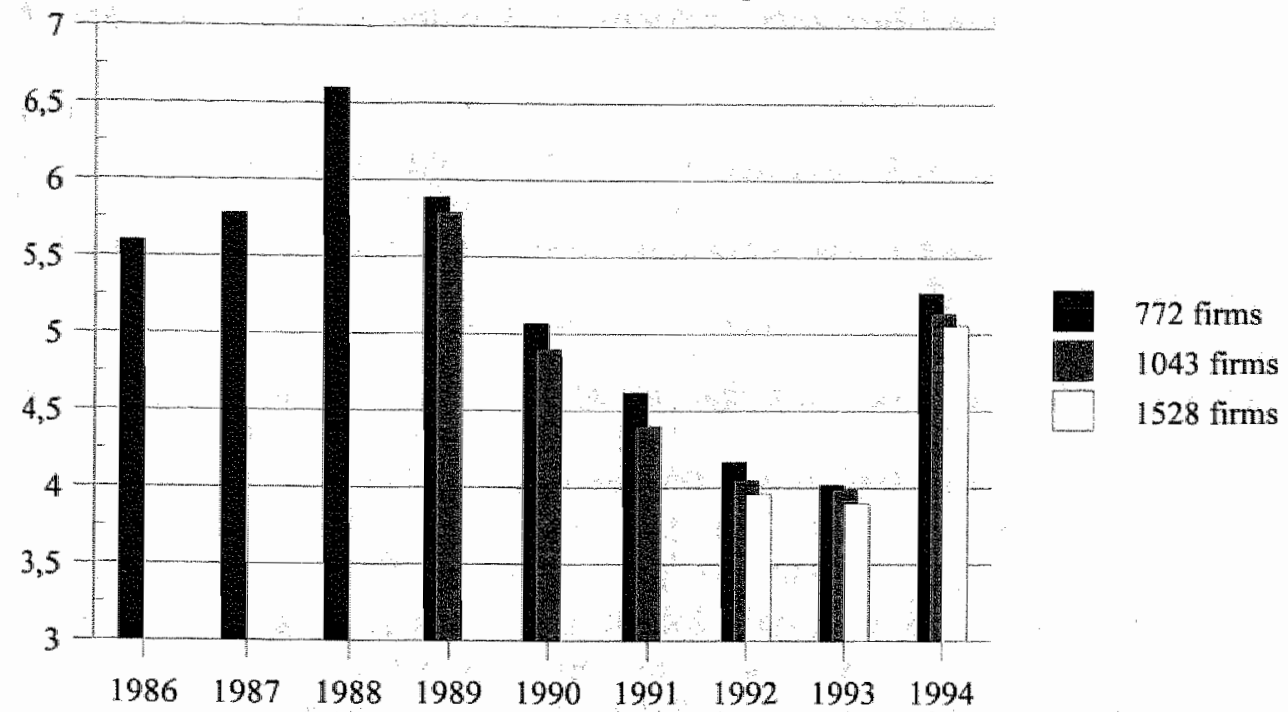

Note: Interest coverage is defined as Standard and Poor's EBITDA interest coverage (Earnings from continuing operations before interest, taxes, depreciation, and amortisation divided by gross interest incurred before subtracting capitalised interest and interest income).

period - to record at least four below median interest coverage observations. ${ }^{20}$ The third and strictest criterion demands further that - in the nine-year balanced panel of firms from 1986 to 1994 - the firm has below median interest coverage in at least six years. We employ the historical balanced panels so that we can be sure that the relative position of the firm in any year is not influenced by entry or exit of atypical firms. Of course, this procedure introduces a survivorship element in the analysis, since firms that are continuously observed for a particular spell of years are probably those with healthy coverage ratios in an absolute sense. Figure 4.1 plots the median coverage ratios for the three historical balanced panels. The survivorship aspect is visible in two ways. First, the longer the time period, the healthier the median interest coverage ratio for any balanced panel. Second, in an absolute sense, interest coverage ratios ranging from four to well above six are quite healthy. For the interpretation of our results, therefore, this implies that the firms that we indicate as carrying a

20 We require the first criterion to be met so that we can be sure that the firm is heavily (or lightly) indebted at the start of our analysis period. In the absence of this compound requirement, a firm that is reducing (raising) its debt burden over the years and actually enters our analysis period with a light (heavy) debt burden is nevertheless still classified as heavily (lightly) indebted. 
relatively heavy debt burden might be assigned a much lighter debt burden when compared with a broader sample of firms. Hence, our estimates are probably extremely conservative and observed patterns much stronger in general than obtained from this analysis.

Having characterised the debt burden of the firm, we subsequently investigate and compare the segment investment behaviour in firms with heavy and light debt burdens. The estimation results are presented in table 4.4 . The estimated segment investment equations display the following pattern. For segments of heavily indebted (low coverage) firms, investment is significantly and positively related to own cash flow. For segments of lightly indebted (high coverage) firms, own cash flow has no statistically discernible impact on investment, but segment sales growth does. The latter did not contribute to the explanation of segment investment for segments of heavily indebted firms. These findings go a long way to corroborate with those of Peyer and Shivdasani (2001). In particular, we might conclude from our estimation results that segment investment within heavily indebted firms is focussed more on the generation of cash flow (for instance to meet contractual interest payments) while segment investment in lightly indebted firms is more focussed on the exploit of profit opportunities.

Contrary to the Peyer and Shivdasani findings, however, we cannot conclude that segments of heavily indebted firms operate more on a stand-alone basis: other cash flow has no statistically or economically significant effect on segment investment regardless of the historical indebtedness of the firm. ${ }^{21} \mathrm{We}$ have already discussed the possible effect of our short sample and generally good credit conditions during the sample period on the probability of finding evidence on internal capital markets (refer to section 4.2). Because firms are not induced to make use of the internal capital markets in our particular sample, we find variation in the debt burden to be uninformative regarding differences in segments' investment sensitivity to other segments' cash flows. Put differently, the absence of a meaningful difference in sensitivity to other cash flow may derive from our sample-specific characteristics as well. Nevertheless, the observation that segments of heavily indebted firms collectively behave differently from segments of lightly indebted firms does suggest the presence of inter-segment financial connections.

21 Please note that concentrating the analysis on the smallest and largest segments only is less relevant in this case than it was for analysing the impact of diversification. The reason being that the debt burden directly affects the working of the internal capital market rather than (more indirectly) extending the potential scope for inter-segment redistribution of funds. Nevertheless, we ran regressions for the smallest and largest segments as well and the general findings are quite similar to those reported in the table for all segments. 


\section{Table 4.4}

Segment investment for firms with high and low indebtedness

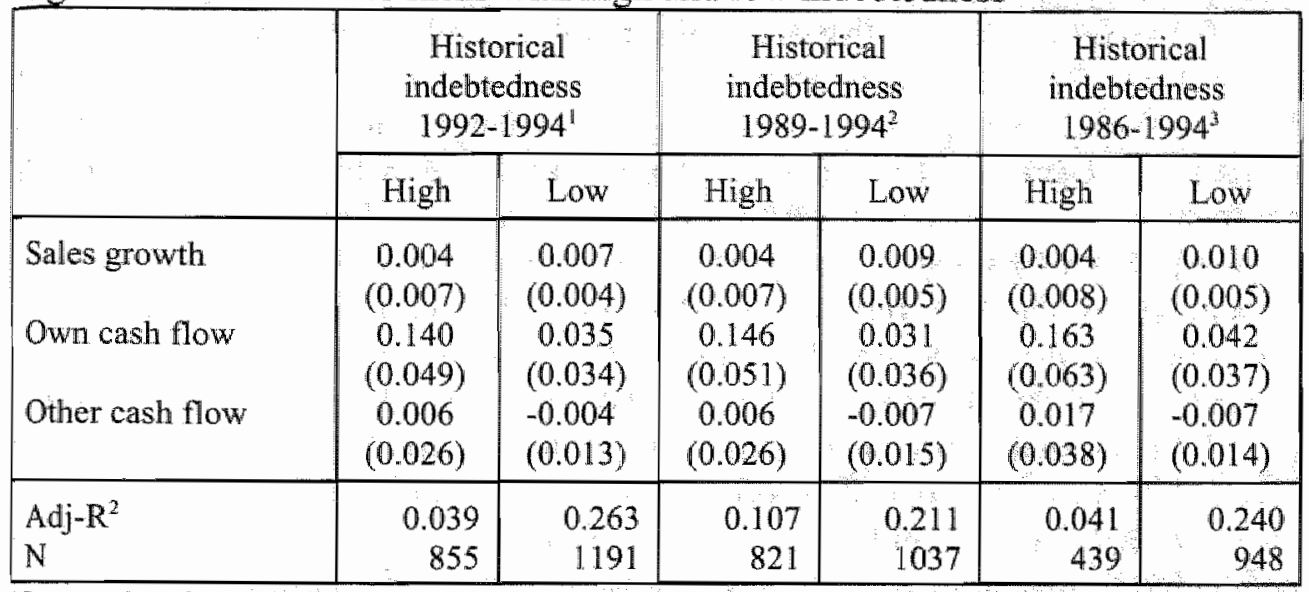

Notes: the dependent variable is segment investment as defined in table 4.1. All other variables are also defined as in table 4.1. Standard errors are in parentheses.

I Historical indebtedness is marked as low if the firm - in a balanced panel of firms observed from 1992 to 1994 - recorded only above median coverage ratios; it is marked high if only below median coverage ratios are necorded.

2 Historical indebtedness is marked as low if the firm - in a balanced panel of firms observed from 1989 to 1994 - recorded at least four above median coverage ratios and if Historical indebtedness 1992-1994 is marked as low as well; it is marked high if at least four below median coverage ratios are recorded and if Fistorical indebtedness 1992-1994 is marked high as well.

3 Historical indebtedness is marked as low if the firm - in a balanced panel of firms observed from 1986 to 1994 - recorded at least six above median coverage ratios and if Historical indebtedness 1989-1994 is marked as low as well; it is marked high if at least six below median coverage ratios are recorded and if Historical indebtedness 1989-1994 is marked jigh as well.

\subsection{Summary and conclusions}

We have investigated the presence and functioning of internal capital markets with a unique database consisting of linked information on Dutch firms and the segments that constitute these firms. In particular we have focussed on the sensitivity of segment investment to funds generated by other segments that are part of the same firm. We have analysed segment investment for different types of firms: we have considered segments within moderately versus highly diversified firms; firms that do or do not house a financial segment, and; firms characterised by a historically heavy or light debt burden. 
Overall, we conclude that there is little evidence that segment investment is structurally dependent on funds generated elsewhere in the firm. Put differently, we do not find evidence that internal capital markets are widely used within Dutch firms. These findings apply to diversified as well as undiversified firms, for the smallest as well as the largest segments thereof, and also to segments of firms that are historically heavily or lightly burdened with debt. These results contrast with findings derived from US databases, where other cash flow generally has a meaningful impact on segment investment. We feel that we have to emphasise the fact that we have computed very conservative estimates regarding the degree to which segments (have to) rely on each other for the financing of their investment. In particular, the rationale for making effective use of the internal capital market stems from the unavailability of easy access to external finance at reasonable terms. Our sample period (1995-1998) can be characterised by a healthy economic environment that is perhaps not so conducive to problems of asymmetric information that usually help to explain binding financing constraints. Thus the incentive for inter-segment reallocation of funds may be limited for the majority of the firms we analyse. Further analysis on the available US data over longer periods of time with the emphasis on the impact of general economic conditions and the overall availability of external finance would be of great help for a more distinct interpretation of our findings in this regard.

Another result that appears throughout the analysis is that segment's own cash flow is an important driving force of segment investment, a finding that corroborates results at the firm level discussed in the previous chapter. In many instances segment cash flow is more important in the explanation of segment investment than our measure of profit opportunities. For segments belonging to firms with a historically light debt burden, however, we obtain the opposite result. In these firms, segment investment is solely driven by sales growth, a finding that is in line with related studies on US data. At the same time, however, the focus of investment on profit potential within these firms does not lead to active inter-segment subsidisation of the fast growing segments. For segments of historically heavily indebted firms, in contrast, investment is driven not by sales growth, but solely by segments' own cash flows. These results also relate to findings at the firm level reported in chapter 3 . Specifically, there we obtained that investment of firms historically more levered is more sensitive to cash flow than investment of firms that have lower leverage ratios (refer to table 3.4). In combination with the present results, we may therefore cautiously conclude that finance becomes more important for investment of the heavily indebted firm, because the internal capital market fails to function properly in such circumstances. 
We find highly interesting and innovative results concerning the use of internal capital markets in firms that house a financial segment. In these firms we do find statistically discernible and economically meaningful redistribution of funds across segments. We have attempted to isolate the impact of a financial segment as stemming from the presence of either a financial holding (a headquarters à la Stein, 1997) or a financial segment that is related to a financial institution (a 'house-bank' à la Hoshi et al., 1991). The results suggest that both types of financial segments foster the mechanism of internal reallocation of funds across the different segments of the same firm. The presence of a financial segment is thus associated with the active use of internal capital markets, possibly through the organisational structure of the firm. Further research is needed, however, to identify the exact causal connections in this regard.

Lastly, we want to shortly address a general concern with analyses that focus on differential cash flow sensitivities in investment equations: the possibility that structural mismeasurement of profit opportunities may impose the observed differentials and hence drive the conclusions (refer also to section 2.2. and 2.3). Whited (2001) in this regard shows that measurement error in $Q$ accounts for most of the differential sensitivity of investment to (other) cash flow and $Q$ itself between segments of conglomerates and standalone firms. Our analysis, however, does not stress behavioural differences between conglomerates' segments and standalone firms. Rather, we emphasise differences in the investment equation for segments belonging to conglomerates with a specific organisational or financial structure. It is therefore unclear to what extent the Whited (2001) critique applies to the presented findings. See Gilchrist and Himmelberg (1995) for an illustration of how mismeasurement influences cash flow sensitivities of investment, but cannot account for the observed differences between various groups of firms. Further research is therefore required to improve the understanding of the impact of measurement error on the specific research strategy employed above. 


\section{Appendix: The data}

The data we use in our empirical analysis are collected at three different sources by Statistics Netherlands (CBS). Balance sheet information on firms is obtained from the $\mathrm{SFGO}$, a survey concerning the roughly 2,500 large enterprise groups in the Netherlands. Segment production and income statement information is obtained from the Structural Business Statistics (or Production Survey, PS) which, in conjunction with a segment level survey on tangible investment (Investment Survey, IS) provides the necessary information for estimating segment investment equations. The MICRONOOM database provides the unique linking of segments to firms, the crucial key to our analysis.

Within the SFGO the statistical unit of analysis is the 'group of enterprises'. A group of enterprises - which we refer to as 'firm' - results from consolidating the Dutch activities of a collection of legally connected enterprises. The SFGO collects detailed information on balance sheet and income statement items of all non-financial firms. Note that the financial enterprises are not included in the consolidation of firms' finances. Furthermore, the statistical information covers all the activities of enterprises operating within the Dutch borders, thus including foreign enterprises operating in the Netherlands but excluding Dutch enterprises operating abroad. SFGO questionnaires are sent to the entire population of large firms (i.e. with balance sheet length $\geq$ NLG 20 million). The response rate generally lies between 80 and 90 percent, covering some 95 percent of the total population value of the most important variables. Firm financial information is available from 1977 to 1998.

Within the PS the statistical unit of analysis is the 'enterprise', to which we refer as 'segment'. The PS is also aimed at covering non-financial activities. The survey does not provide information on segments' balance sheet items, but is focussed instead on a very detailed reproduction of income statement items. The PS is not designed to cover 100 percent of the population. It relies on stratified sampling instead. Only the population of the largest segments (100+ employees) is covered in full. Medium-sized segments (10-99 employees) are represented by random samples such that $50-75$ percent of the population is covered. For the small segments (1-9 employees) this coverage ratio lies between 10 and 20 percent. It should be noted that the largest segments constitute one half to two thirds of the total population value (i.e. sum over all segments in all size classes) of most of the important variables. The setup is similar for the Investment Survey, which focusses exclusively on segment investment. The PS and IS information required for the present analysis is available from 1995 to 1998 . 
Firms and segments are linked within the MICRONOOM database using information from the Business Registration files. Legal entities provide the crucial linking device. Each firm as well as each segment is a legal entity or is built from a structure of legal entities. Regarding the firm, this usually takes the form of mother-daughter relationships, while for segments legal entities are grouped together when they very clearly exist in order to engage in a specific economic activity (segments always represent an economic, rather than a legal unit). For example, a chain of supermarkets may constitute one legal entity (a Retail activity), a chain of alcohol shops another (also a Retail activity), and a supermarket distribution centre a third (a Transport activity). If the specific distribution centre has as it main task the supply of the chain of supermarkets, then the first and the third legal entities are combined into one segment (and given the supplement Retail activity). The chain of alcohol shops constitutes a separate segment (remains Retail activity). Now suppose that both segments are owned by the same financial holding company. Then the legal links between the segments and the holding company facilitate the construction of one firm that in this case consists of four legal entities, three segments (of which only the two non-financial segments actually appear in the data) and is active in the retail sector. This firm-segment linking algorithm is available from 1995 to 1998. 


\section{Part II \\ Informational Problems \\ and \\ Corporate Liquidity Holdings}

In the first part of this thesis we have focussed primarily on the relation between corporate investment and finance in an environment characterised by asymmetric information. Informational problems make external finance more expensive than internal finance and we have shown in chapter 2 how this makes investment sensitive to changes in internal funds. The corporate liquidity decision remained largely in the background in this analysis. Nevertheless, corporate liquidity is valuable to the firm when external finance commands a premium. Its value derives from saving the firm the walk to external capital markets to obtain expensive funds when contemporary earnings fall short of planned (investment) expenditures. Firms can then run down their liquidity holdings instead. In fact, pecking order models of capital structure for example by Myers and Majluf (1984) build on this notion: a firm should use internal means first when financing investment and turn to external capital markets only when its internal means - including holdings of liquid assets - have been depleted. The derived implication is that those firms that have depleted their internal means face binding financing constraints: they have to resort to expensive external finance and possibly forego profitable investment. Likewise, firms which have a surplus of internal means are those who finance all profitable investment internally and are left with idle balances of internal funds. Such firms are therefore unconstrained.

In chapter 2 we also discussed the contribution of Kaplan and Zingales (1997), who apply this idea to the analysis of financing constraints. Their two main findings are the following. First, firms which are classified as constrained on the basis of their retention practice appear quite rich in terms of the internal means they have at their disposall. This suggests that they are, in fact, not constrained at all. Kaplan and Zingales propose an alternative classification of firms on the basis of the availability of internal means for the financing of additional investment. This relates to their second finding: the sensitivity of investment to changes in internal funds is not a monotonic function of the level of internal funds. Particularly the latter finding leads Kaplan and Zingales to conclude that the investment-cash flow sensitivity is not a useful indicator of financing constraints. For the remainder of this thesis, we want to examine these 
two findings more comprehensively: Specifically, we want stress that the simple treatment of internal funds as a mere source of cheap contemporary finance does not do complete justice to the important role it plays in the inter-temporal allocation of finance and investment. Allowing for a distinct precautionary motive to hoard internal means - motivated importantly by informational problems in capital markets - we explain the above two findings in a way that accommodates the interpretation of investment-cash flow sensitivities as useful indicators of financing constraints. In the analysis of the determination of holdings of internal funds, our focus is on liquid assets only, for two reasons. First, in our empirical analysis, semi-liquid assets such as working capital are found to be poor substitutes for liquid balances. Second, fixed investments in for instance commercial real estate may be a poor way of securing liquid internal funds (cf. Holmström and Tirole, 2000, p. 296). On the one hand, liquidation costs may hamper the quick conversion of such assets into cash at their true value(e.g., chapter 3 ). On the other hand, the value of such assets may be depressed when the firm is in need of funds (e.g., Holmström and Tirole, 2001).

In chapter 5 , we therefore focus on the determination of corporate liquidity holdings. We develop the argument that precautionary liquidity is valued to accommodate adverse shocks to future earnings and/or to initiate profitable future investment for which external finance cannot be attracted. Put differently, we embrace the notion that liquidity is valuable to the firm as a source of inexpensive finance for future investments. In addition, we acknowledge the idea that informational problems make liquidity valuable to a firm as a source of inexpensive finance for contemporary investment. Taken together this suggests that firms have incentives both for spending liquid assets for the financing of contemporary investment and for hoarding them for future needs. We resolve this apparent contradiction in chapter 5 by arguing that the former incentive only impacts on corporate liquidity in the short run, whereas the latter is the long-run driving source of corporate liquidity holdings. Our empirical results support this conjecture; in an error correction framework we demonstrate that firms let contemporary developments in cash flow and investment be absorbed by liquidity holdings, while at the same time they pursue long-run liquidity targets. Precautionary liquidity holdings are therefore important for the firm in coping with present as well as future capital market imperfections. This also relates to Kaplan and Zingales' first finding: overly liquid firms may seem unconstrained today, but they possibly expect future financing restrictions that make them behave constrained now despite their apparent richness.

While firms let for instance contemporary financing needs affect liquidity holdings, they cannot lose track of their long-run targets too much, 
even in the short run. Indeed, our empirical findings in chapter 5 already point to considerable adjustment efforts even in the short run. At the same time, compared to such key decision variables as capital stock and capital structure, corporate liquidity is probably the least expensive variable to adjust. For profit maximising firms, therefore, it is optimal to have liquidity holdings accommodate postponed adjustment in the capital stock or the capital structure. A strategy of keeping liquidity always 'on target' is strictly inferior. This begs the question, addressed in chapter 6, of when exactly the importance of liquidity adjustment becomes the firm's predominant short-run goal. This is an important issue because it gives for instance an indication of how much variation in corporate liquidity holdings is 'normal' in the sense that it does not unduly affect real (investment) decisions of the firm. While there is undoubtedly an important monetary policy aspect to this observation, within the main theme of this thesis, the crucial aspect is that we get an idea of when it is that corporate liquidity holdings likely affect the investment decision. We find that there is a relatively large range of inaction around the corporate liquidity target in which the liquidity ratio may more or less freely vary without inciting efforts to adjust this ratio back to target. When liquidity has strayed too far from optimal levels, however, short-run target adjustment efforts increase considerably.

In chapter 7, we relate the results from chapters 5 and 6 to Kaplan and Zingales' second finding. There, we examine the sensitivity of investment to cash flow for firms with low, normal, and high holdings of liquid assets relative to target. Our results suggest that investment becomes more sensitive to the inflow of cash when the firm's contemporary liquidity holdings fall short of its target and vice versa. This observation corroborates with a financing constraints explanation: contemporary financing constraints play a more prominent role for firms with shortages of liquidity relative to target liquidity. For liquidity holdings that fall so low relative to targeted levels that financial distress possibly looms, we find that most of expected cash flow is directed towards the stock of liquid assets. As a corollary, investment then becomes less responsive to cash flow. At the same time, our results demonstrate that no clear relation exists between the level of observed liquidity holdings or the long-run liquidity target on the one hand and investment-cash flow sensitivity on the other hand. We conclude from these findings that observed corporate liquidity holdings are an imprecise indicator of contemporary financing constraints. 
${ }^{2}$

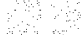

8

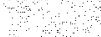

(a)

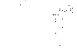

(2) 


\section{Chapter 5 \\ The Determinants of Dutch Corporate Liquidity}

\subsection{Introduction}

Firms structurally invest in liquid assets. Opler, Pinkowitz, Stulz, and Williamson (1999), for example, document that for their sample of publicly traded US firms the liquidity ratio amounts to around five percent during the period 1971-1994. Kim, Mauer, and Sherman (1998) report an average liquidity ratio of roughly eight percent for US industrial firms in the 1975-1994 period. Nevertheless, the value of corporate liquidity is an unresolved question in the theory of finance (e.g., Brealey and Myers, 1.996).

The purpose of this chapter is to build a synthesis of two opposing theoretical approaches to corporate liquidity motives and to examine their relative contribution to the explanation of corporate liquidity holdings in the Netherlands. Specifically, we are interested in the issue of whether firms actively pursue implicit liquidity targets or whether liquidity holdings are deemed unimportant and therefore passively adjust to (more important) financial decisions taken elsewhere in the firm.

The empirical literature so far on this topic is sparse - mainly due to a lack of high-quality firm-level data - and it does not provide clear-cut answers to this point. Kim et al. (1998) provide empirical support for the theoretical "tradeoff between low return on liquid assets and the benefit of minimizing the need for costly external financing". Opler et al. (1999) stress a distinction between the active formulation and pursuit of liquidity targets on the one hand and a more passive stance on the other. According to the latter view, liquidity follows from the pursuit of a net debt target or pecking order behaviour in finance. For the Netherlands, De Haan, Koedijk, and De Vrijer (1994) find evidence for buffer stock determinants of corporate liquidity using qualitative survey data.

In this chapter, we extend on and improve the currently available empirical literature in two ways. First, we exploit a new firm-level data set for large non-financial firms in the Netherlands. Because the Netherlands is a country with a predominantly bank-based financial system in combination with low shareholder rights, we are able to present evidence complementary to the literature, which is dominantly US oriented. The US is characterised by a market-based system as well as by relatively high shareholder rights. 
Since the data consistently cover the twelve year period 1986-1997, we are able not only to investigate cross-sectional characteristics of liquidity holdings but to include a time dimension as well. This immediately brings us to the second innovation. Contrary to the existing literature on firm liquidity holdings, we propose a clear-cut distinction between the determination of corporate liquidity in the short run and the long run. In our view, the possible existence of corporate liquidity targets can only be judged by looking at longrun characteristics. We argue that short-run cash dynamics may have a dominantly passive character both with and without clear-cut targets. Without a target, a firm's liquidity both in the short run and in the long run is determined by its cash flows as forcefully argued by the pecking order theory. However, even with a target a firm's short-run liquidity dynamics may depend on its current performance through the buffer stock approach as introduced by Carr and Darby (1981). Consequently, short-run evidence is unable to distinguish between the two hypotheses due to observational equivalence. Long-run liquidity behaviour will more clearly show whether implicitly formulated liquidity targets or ranges are actively pursued.

Therefore, we analyse liquidity holdings in an error correction framework to integrate the different views on liquidity holdings in a testable way. Estimation results are supportive of our conjectures. The main thrust of our empirical findings is that a target adjustment framework for corporate liquidity holdings may feature short-run dynamics that are in line both with pecking order behaviour and buffer stock behaviour. Long-run pecking order determination of corporate liquidity, however, is rejected by the existence of optimal liquidity ratios that are motivated by static trade off arguments. As a corollary, we find reversion to firm-specific liquidity targets at a rate of eighty percent per year. This is in sharp contrast with the adjustment speed of money demand in aggregate data, usually found in the literature. Our results point to the existence of aggregation problems.

The plan of the chapter is as follows. In the next section, we summarise the theoretical determinants of corporate liquidity. We pay specific attention to the role of informational problems in the determination of the precautionary demand for liquidity. Also, we elaborate on the distinction between liquidity determination between the short and long run. In section 5.3 we present and characterise the data and construct the variables used in our empirical analysis. In section 5.4 we present our estimation results using an error correction framework and in section 5.5 we summarise and conclude. 


\subsection{The determinants of corporate liquidity}

In this section, we start with a discussion of the standard determinants of corporate holdings of liquid assets. In this respect, we distinguish between the presence of transaction costs and opportunity costs in section 5.2 .1 . In section 5.2.2 we discuss informational problems as an explicit motivation for precautionary corporate liquidity holdings. Together, the factors discussed in sections 5.2.1 and 5.2.2 yield an optimum liquidity level or ratio, which we label the static trade off level, following Opler et al. (1999). In section 5.2.3 we turn to another branch of the literature, where liquidity holdings are assumed to adjust passively to other financial decisions taken by the firm. This may reflect pecking order behaviour and the absence of any actively pursued liquidity target, but also it may reflect the buffer stock property of liquidity in the short run only and a longer-term return to a target. Buffer stock and pecking order arguments are therefore compared to the static trade off view in section 5.2.4.

\subsubsection{Transaction and opportunity costs}

The presence of positive transaction costs alone is sufficient to create a positive demand for liquidity. With zero opportunity costs, optimal holdings of corporate liquidity are unbounded. When opportunity costs are positive, however, firms will economise on liquidity holdings. Transaction and opportunity costs together then determine a positive and finite optimal amount of corporate liquidity holdings. In applied work, often used variables to capture the transaction motive are sales (in an inventory approach) or assets (in a Keynesian or portfolio (ramework). A benchmark interest rate is then generally assumed to account for the opportunity cost of holding liquid assets. More generally, all relevant substitutes for liquidity such as net working capital and minority holdings in other firms may need to be taken into account.

In addition, a precautionary demand for money may exist. One argument is the expectation of future investment opportunities. A second argument concerns uncertainty regarding future cash inflows and outflows. In particular, firms characterised by a more volatile cash flow history will desire a larger precautionary stock of liquidity. Third, firms with large amounts of short-term debt possibly face a larger degree of refinancing uncertainty (Holmström and Tirole, 2000). This last factor is closely related to the informational motives for holding liquidity. The relation stems from the fact that refinancing becomes more uncertain when there is a possibility that future debt rollovers are denied. We turn to this issue now. 


\section{2 .2 Informational problems}

Informational problems between firms and financial markets may have an impact on the availability of external finance as well as its premium. Although in itself this already suggests that liquidity is valuable, the explicit precautionary demand for liquid assets is inherently forward-looking and tied to the need for long-term financing. Regarding the future availability of external finance, Holmström and Tirole (1998) develop a model of investment with moral hazard that features an explicit demand for liquidity. In the model, firms invest in a productive technology using a combination of own funds and debt. The investment horizon is two periods and after the first a liquidity shock hits the project. The liquidity shock obliges the firm to inject additional funds into the project lest it terminates midstream. During the second period, the firm privately determines the probability that the project is completed successfully. It is assumed that diligence produces a strictly positive expected return. Shirking produces a negative expected project return, but gives a private benefit to the firm. To ensure diligence, therefore, the firm must be ensured a stateindependent incentive compatible level of earnings. As such, moral hazard creates the possibility that - after a liquidity shock has occurred - the firm cannot credibly pledge a nonnegative return to outside investors even though the continuation value of the project is strictly positive. Holsmtröm and Tirole (1998) therefore demonstrate that "liquidity shocks could force the firm to terminate a project midstream even though the project has positive continuation value. To protect itself against such risks, the firm wants to hold [for instance] liquid reserves in the form of marketed assets that can be readily sold" (p. 2).'

More generally, informational problems in capital markets raise the difficulty and cost of obtaining external finance and hence create a (precautionary) demand for corporate liquidity. ${ }^{2}$ De Haan, Koedijk, and de Vrijer (1992) find supportive evidence for this hypothesis examining Dutch corporate liquidity holdings through a survey questionnaire. We label this effect the informational cost of external finance. It can occur through firm-specific characteristics, but also through sector- and time-specific factors.

1 Extension of this argument to the findings in the previous chapter suggests that multi-divisional fums also have the option to reallocate funds internally between segments using the internal capital market, provided that they have a supportive organisational structure. This reduces incentives to hoard liquidity for precautionary purposes.

2 Firms with the most severe information problems may also be restricted to issuing expensive short-term debt instead of more favourable long-term debt à la Diamond (1991a), which by itself stimulates a higher precautionary demand for liquidity (Holmstrom and Tirole, 2000). 
An example of a firm-specific characteristic is the amount of leverage. In general, higher leverage increases moral hazard and thus the marginal cost of debt, see Freixas and Rochet (1997) and Hubbard (1998). With higher leverage, a firm faces a higher degree of uncertainty regarding future access to debt financing and desires higher precautionary liquidity holdings. ${ }^{3}$ This theoretical consideration is in line with empirical findings of De Haan (1997) and Van Ees, Garretsen, De Haan, and Sterken (1998) who, for a sample of Dutch firms, find that a debt-constraint augmented model of investment outperforms a neoclassical specification. Another example is the informational sensitivity of a firm's activities. Investment in research and development (R\&D), for instance, is likely to be subject to stronger asymmetries in information than investment in manufacturing plants and equipment (e.g. Opler et al., 1999).

Sector- and time-specific factors may add to this. Investments in the ICT sector may be more sensitive to asymmetric information than investments in the manufacturing sector (cf. Schaller, 1993; Chirinko and Schaller, 1995; Weigand and Audretsch, 1999). Similarly, investments in recessions may exhibit a stronger informational sensitivity compared to investments in booms (cf. Calomiris, Himmelberg, and Wachtel, 1995).

Another form of informational asymmetries potentially affecting liquidity holdings arises from the existence of agency problems between management and owners of a firm (cf. Grossman and Hart, 1983). Managers may value corporate liquidity higher than owners and thus desire higher liquidity targets for a number of reasons. First, management may be overly concerned with liquidation risk, whereas shareholders can more easily diversify and so reduce the impact of a single bankruptcy on their portfolio return. Shareholders therefore likely put more emphasis on profits and hence prefer lower levels of precautionary liquidity. Second, managers may be empire builders rather than profit maximisers. ${ }^{4}$ Empire builders value projects that add to the size of the firm without necessarily being profitable. As the market does not value such projects, empire builders prefer a precautionary amount of liquidity that allows them to exploit empire building investment opportunities. Third, management

3. Myers and Rajan (1998) on the other hand suggest that higher liquidity may worsen the information problem rather than cure it. In that case, the cost of external finance may increase in liquidity holdings. Also see Morellec (2001). For empirical illustrations see for instance Weiss and Wruck (1998) or De Angelo et al. (2002).

4. Hart and Moore (1995) and Freixas and Rochet (1997, particularly pp. 125-129) consider behaviour of empire builders. In Freixas and Rochet, empire builders are constrained by debt contracts, which reduce free cash flow (managerial discretion) and hence limit the opportunity to invest in negative net present value projects. 
may also value liquidity more than shareholders do simply because it can be freely spent on perquisites, see Jensen (1986).

Therefore, corporate liquidity holdings will generally increase with managerial discretion. The costs of managerial discretion will be lower, the more a firm is subject to monitoring and the disciplining forces of the (capital) markets. To the extent that relationships with financial intermediaries induce information production and monitoring activities (cf. Diamond, 1984, 1991b), managerial discretion is limited and corporate liquidity holdings will be reduced. ${ }^{5}$ Thus we may expect that higher leverage leads to lower levels of liquidity through the monitoring channel. Moreover, strong bank relations may cause a firm to feel comfortable with lower levels of precautionary liquidity, since banks are critical providers of liquidity, especially when the market develops unfavourably, see Boot (2000) and Saidenberg and Strahan (1999). On the other hand, Macey and Miller (1997) hypothesise that banks may try to reduce corporate risk taking and desire the firm to hold high levels of precautionary liquidity. Hence a bank-based system - like the Dutch one - may stimulate large holdings of corporate liquidity. Pinkowitz and Williamson (2001) document empirical support for this hypothesis in the case of Japan and to a lesser extent for Germany.

\subsubsection{Pecking order behaviour and buffer stock liquidity}

In contrast to the static trade off view on corporate liquidity demand is the view where liquidity is passively drifting along on the waves of fortune of the firm. Such a view does not directly follow from the strict pecking order theory, which focuses on the passive adjustment of capital structure in general and net debt in particular (e.g., Myers and Majluf, 1984). However, it is consistent with this theory. ${ }^{7}$ In this view, firms care little about the amount of liquidity that is

5 Other factors may have an impact on managerial discretion as well. Dispersed ownership, size of the firm, and charter amendments may act as takeover deterrents. This lowers capital market discipline and therefore, all else equal, raises corporate liquidity holdings.

* This argument counteracts the earlier hypothesis that higher leverage leads to higher liquidity holdings due to refinancing uncertainty (cf: Holmström and Tirole, 1997; Bolton and Freixas, 2000). However, we note that the monitoring and information production effects stemming from long-term debt are probably larger than those stemming from short maturities (e.g, Diamond, 1991a; Freixas and Rochet, 1997) so that our earlier conjecture remains unambiguous when related to short-term debt.

In theory, liquidity targets may also be absent if a firm has an optimal capital structure which is cast in the form of a net debt target, see Opler et al. (1999). 
reported on their balance sheets. Rather, they let liquidity holdings adjust passively to discrepancies between inflows and outflows of funds. In its extreme form, pecking order liquidity behaviour predicts that all expenses (investment in fixed assets and working capital, debt repayments, dividend payments, and so on) are extracted from liquid assets. All revenues (cash flow, new debt, sale of fixed assets or working capital) are added to it. De Haan (1997) presents evidence that suggests that pecking order arguments are relevant determinants of Dutch corporate capital structure adjustments.

Closely related to this concept is the theory of buffer stock liquidity. According to the latter, firms may initially choose to let their liquidity holdings absorb any shocks, while they try to return to an optimal level of corporate liquidity in the longer term. Note that buffer stock liquidity does not necessarily assume that firms are unaware of the benefits and costs of corporate liquidity. A sufficient condition is that the firm stresses other financial targets more than it does liquidity holdings. De Haan et al. (1994) find that for Dutch firms corporate liquidity holdings exhibit distinct elements of a buffer stock approach while at the same time elements of pecking order behaviour characterise capital structure adjustment.

\subsubsection{Static trade off versus buffer stock and pecking order behaviour}

The theoretical divide between the static trade off and buffer stock views on corporate liquidity is largely artificial. The difference mainly lies in the time horizon of the analysis. In particular, consider a precautionary demand for liquid balances driven by informational problems in the capital markets. According to the static trade off view on liquidity, an increase in these informational problems pushes the related (long-run) precautionary demand for liquidity upwards. Dynamically, if these same informational problems at a point in time restrict access to external finance, firms run down liquidity. The important realisation is that this short-run behaviour is possible because of the long-run target level. At the same time its 'shock absorbing' nature is exactly in line with the buffer stock view on liquidity. We refer to Shyam-Sunder and Myers (1999) for a similar argument with respect to a firm's optimal capital structure.

The theoretical divide between the static trade off and pecking order views on corporate liquidity is nontrivial. Strict pecking order behaviour in finance implies that long-run liquidity targets do not exist. Hence we can test for the role of pecking order determination of long-run corporate liquidity levels by assessing the long-run impact of sources and uses of funds. In a static trade off world, such influences have a short-term character and do not influence longrun targets. With a pecking order, these influences extend to the long run. Unfortunately, the short-run implications of pecking order behaviour as the 
driving force of corporate liquidity holdings are empirically difficult to discriminate from buffer stock behaviour. The reason is that both the buffer stock view on corporate cash and the pecking order imply that liquidity rises when the sources of funds exceed the uses of funds and vice versa. Hence we may - and in fact will - find short-run corporate liquidity behaviour seemingly supporting the pecking order view while simultaneously long-run liquidity targets are relevant and actively pursued.

\subsection{Data and variable definition}

\subsubsection{Data structure}

The data used for the empirical testing of our corporate liquidity holdings framework are derived from Statistics Netherlands' data on the Finances of Large Firms (SFGO) covering the period 1977-1997. The SFGO provides company-specific financial information at the level of balance sheet and income statement items for all large Dutch non-financial firms. ${ }^{8}$ On an annual basis, the data cover 80 to 90 percent of the population. In the early years, the number of firms on which Statistics Netherlands reports is quite small. Moreover, data then only cover the manufacturing sector. Data on the services sector start becoming available in 1983 and in the subsequent 3 years coverage increases substantially. Therefore, we choose to use the period 1986-1997 for our analysis. Occasionally, firms do not report in a given year so that missing data entries arise. We only include firms for which we observe no missing data." A balanced panel of 473 firms results, of which 197 are manufacturing firms and 182 are services firms. ${ }^{10}$

* The size requirement for inclusion in the $\mathrm{SFGO}$ is a balance sheet length of at least 20 million Dutch guilders. If a part of a non-financial firm operates in the financial sector, that part - but not the firm itself - is removed from the data.

In some cases, firms may leave due to financial distress, raising the issue of survivorship bias or because they drop below the threshold level of assets. However, in many other cases firms do not go bankrupt but simply do not report their financial statements to $\mathrm{SFGO}$ in one or more years after which they return. We are unable to distinguish between these different cases. Survivorship bias does not appear to be the major reason though.

10 Manufacturing firms are those in sectors II (Foods and goodies industries, SBI93 15, 16), III (Petrochemical industry, SBI93 23), IV (Chemical, rubber, and synthetic materials producing industries, SBI93 24, 25), V (Metals, machines, and transports producing industries, SBI93 27-35), VI (Other industries, SBI93 17-22, 26, 36, 37), and VII (Public utilities, SBI93 40,41). Services firms are those in sectors IX (Wholesale and retail trade, SB193 50-52), X (Hotel and catering industry, SBI93 55), XI (Transportation, storage, and 
Arguably, precautionary liquidity holdings play a more important role in small and young firms, see for example Opler et al. (1999). These are not present in our sample. Any positive evidence for our sample of large firms may therefore be interpreted as a conservative estimate for similar effects in immature and small firms.

\section{Figure 5.1}

Mean corporate liquidity ratios (in percentages)

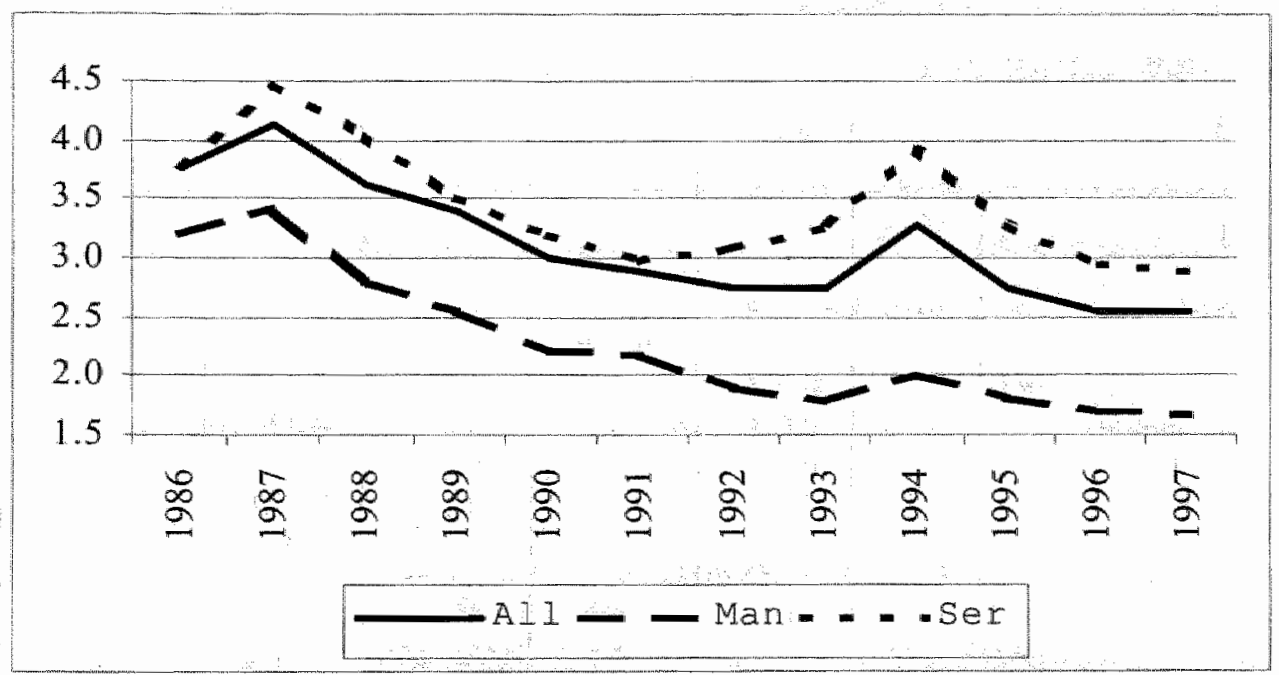

Notes: the liquidity ratio is defined as liquid assets over total assets less liquid assets where liquid assets is the sum of cash, short-term investments, term deposits, and demand deposits. "All" indicates all 473 firms in the balanced panel, "Man" represents the 197 manufacturing firms, and "Ser" represents the 182 services firms.

\subsubsection{Variable definition and descriptive statistics}

Figure 5.1 plots the development of the Dutch corporate liquidity ratio. A few features catch the eye. First, the liquidity ratio has followed a downward trend since 1987 and has declined by more than one percentage point over the sample

communication, SBI93 60-64), and XII (Real estate, personal property, and commercial services, SBI93 70-74). The other firms are in sectors I (Agriculture, fishery, and minerals, SB193 1-14), VIII (Construetion industry, SBI93 45), and XIII (Public services, education, health care, and miscellaneous services, SBI93 75-93). Note that public utilities is not conventionally included in the manufacturing sector. However, the regression analysis showed that the firms in this sector behaved insignificantly different from manufacturing firms. 
period. "Second, there are distinct peaks in 1987 and 1994, which correspond well enough with downturns in the economic cycle to suspect the presence of macro-economic effects on the corporate liquidity ratio. Third and last, services firms systematically have a higher liquidity ratio than manufacturing firms; at the end of the sample period their liquidity ratio is nearly twice as high as that for manufacturing firms. We will explore later on to what extent liquidity targets are formulated differently for services and manufacturing firms.

\section{Table 5.1}

Descriptive statistics: 1986-1997

\begin{tabular}{|l|c|c|c|c|c|c|}
\hline Variable & \# Obs. & Mean & $\begin{array}{c}\text { Standard } \\
\text { error }\end{array}$ & $\begin{array}{c}\text { Standard } \\
\text { deviation }\end{array}$ & Median & $\begin{array}{c}\text { Order of } \\
\text { integration }\end{array}$ \\
\hline Liquidity & 5676 & -3.480 & 0.028 & 2.137 & -3.175 & $\mathrm{I}(1)$ \\
Size & 5676 & 11.863 & 0.018 & 1.334 & 11.565 & $\mathrm{I}(1)$ \\
Assets & 5676 & 11.974 & 0.017 & 1.306 & 11.653 & $\mathrm{I}(1)$ \\
Sales & 5676 & 1.841 & 0.019 & 1.408 & 1.515 & $\mathrm{I}(1)$ \\
Net working capital & 5676 & 0.036 & 0.003 & 0.238 & 0.035 & $\mathrm{I}(0)$ \\
Near liquidity & 5676 & 0.478 & 0.003 & 0.237 & 0.490 & $\mathrm{I}(1)$ \\
Short debt & 5676 & 0.764 & 0.003 & 0.240 & 0.828 & $\mathrm{I}(1)$ \\
Total debt & 5676 & 0.532 & 0.003 & 0.204 & 0.539 & $\mathrm{I}(1)$ \\
Investment & 5676 & 0.078 & 0.001 & 0.073 & 0.059 & $\mathrm{I}(0)$ \\
Dividends & 5676 & 0.032 & 0.001 & 0.092 & 0.003 & $\mathrm{I}(0)$ \\
Cash flow & 5676 & 0.059 & 0.002 & 0.168 & 0.072 & $\mathrm{I}(0)$ \\
\hline
\end{tabular}

Notes: Liquidity is defined as the logarithm of cash and marketable securities over net assets: net assets is total assets less cash and marketable securities; Size is the logarithm of net assets expressed in 1990 prices; Assets is the logarithm of total assets expressed in 1990 prices; Sales is defined as the sales-to-net assets ratio; Net working capital is the sum of short-term claims, inventories, and work in progress less short-term debt to net assets; Near liquidity is the ratio of short-term claims, inventories, and work in progress to net assets; Short debt expresses short-term debt as fraction of short- and long-term debt; Total debt is defined as total debt over total assets; Investment is changes in tangible fixed assets due to purchase or production over net assets; Dividends is defined as total dividend payments to net assets; Cash flow measures earnings after interest and taxes, but before depreciation and dividends over net assets.

1 We use I(O) and I(1) to signify that a series is integrated of order zero and one, respectively, using the Harris and Tzavalis (1999) test and a $95 \%$ level of confidence.

11. Noteworthy in this regard is the fact that the nationall liquidity ratio had been rising since the early 1980 s and was perceived as being excessively high in the late $1980 \mathrm{~s}$ (e.g., Van der Knoop and Hooijmans, 1985; Kuipers and Boertje, 1988; De Haan et al., 1992; De Haan et al., 1994). 
For the remainder of this analysis, liquidity refers to the log of holdings of liquid assets (cash, short-term investments, term deposits, and demand deposits) as a fraction of total assets less liquid assets. ${ }^{12}$ Table 5.1 provides descriptive statistics on liquidity holdings, asset structure (size, assets, net working capital), liability structure (total debt and short debt), and flow of funds characteristics (imestment, dividends, cash flow). We refer to the table for the exact definition of the variables. In addition to firm-specific variables, we include information on share prices as an indicator of the average, economywide availability of external funds. The share price used is the general index reported in the International Financial Statistics of the IMF, expressed in 1990 prices. Over the sample period share prices increased considerably. This behaviour may signal "easy money" and thus indicate smoother access to external funds. As such, it may have contributed to lower precautionary liquidity holdings. ${ }^{13}$ Note that throughout the chapter variable names are in italics.

\subsection{Estimation results}

To combine the long-run and short-run analysis of corporate liquidity holdings; we hypothesise an error-correction specification of liquidity in section 5.42 . In such a specification, the dynamics of liquidity are determined by various shortrun shocks in addition to attempts to drive the actual liquidity level to the desired long-run (static trade off) level. We start, however, with an empirical investigation of the long-run determinants of corporate liquidity in section 5.4.1, to arrive at measures of long-run corporate liquidity targets. The two-step procedure allows us to consider the effect of allowing for firm- and timespecific effects in these targets and their impact on restricted error correction. We elaborate on the motivation to do so later on.

12 Compared to the percentage liquidity ratio, liquidity has the convenient properties of a domain that ranges from negative to positive infinity and a distribution that closely resembles the normal. We elaborate on this point in the next chapter.

13. Note that share prices may also contain business cycle information. If share prices go up together with the business cycle, an expected increase in macroeconomic performance may raise desired transaction balances, countering the negative effect on desired liquidity holdings produced by the increased availability of external funds. 


\section{4 .1 The determination of corporate liquidity levels}

Table 5.1 already contains statistical information about the long-run characteristics of the different series used. In the last column of table 5.1, the order of integration of the variables is indicated. For the assessment of the order of integration we evaluate the normalised least squares estimator of the autoregressive coefficient $(\varphi)$, allowing for fixed effects $(\alpha)$ and a common time trend $(\delta)$, in $y_{i t}=\alpha_{i}+\delta_{t}+\varphi y_{i(t-1)}+\phi_{i k}$. We test $H_{g}: \varphi=1-$ at the $95 \%$ confidence level - versus the alternative $H_{a}: \varphi<1$. Harris and Tzavalis (1999) demonstrate that

$$
\sqrt{N}\left(\hat{\varphi}-1+\frac{15}{2\left(T^{2}+2\right)}\right) \stackrel{w . c .}{\longrightarrow} N\left(0, \frac{15\left(193 T^{2}-728 T+1147\right)}{112(T+2)^{3}(T-2)}\right)
$$

where $w . c$. denotes weak convergence in distribution. Convergence requires $N$ $>100$ and $T$ small relative to $N$, conditions satisfied by our data. ${ }^{14}$

Liquidity is shown to be $I(1)$. This result implies that the long-run level of liquidity is nonstationary. Consequently, the long-run determinants of liquidity must be nonstationary as well. Table 5.1 shows that size, near liquidity, short debt, and total debt all obey this condition and therefore are potential long-run determinants of liquidity. Net working capital, investment, dividends, and cash flow, however, are all $I(0)$. A preliminary conclusion based on the statistical characteristics of these latter variables would be that they are possible driving forces of short-run liquidity dynamics, but not of long-run liquidity targets. It presents indicative evidence against a strict pecking order explanation of liquidity behaviour. ${ }^{15}$

Direct estimates of long-run liquidity targets result from a regression of the level of liquidity on the long-run determinants of liquidity only:

$$
y_{i t}=\beta_{n}^{\prime} x_{i r}+\lambda_{t}+\eta_{i}+v_{i t}
$$

We are aware of the debate in the literature regarding the validity of unit root computation for panel data. For elaboration on this issue, see for instance the surveys by Baltagi and Kao (2000) and Banerjee (1999). We compute unit root test statistics using the Harris and Tzavalis (1999) technique; a choice that is motivated by the small $T$ character of our panel.

15 According to the pecking order theory "flow of funds variables (like for instance cash flow) would be the dominant short-run and long-run determinants of corporate liquidity holdings, see Opler et al. (1999). Despite its $I(0)$ character, we explored the role of cas $h$ flow as a long-run determinant of corporate liquidity here. The (unreported) estimation results show that parameter estimates are negative and statistically insignificant, leading us to reject this hypothesis. 
where $y$ represents liquidity and $x$ stands for the vector of explanatory variables. Time- and unit-specific random effects are captured by $\lambda_{t}$ and $\eta_{i}$, respectively, while the remaining white-noise error is indicated by $v_{i t}$.

\section{Table 5.2}

Level estimates of corporate liquidity

\section{PANEL A ESTIMATION RESULTS}

\begin{tabular}{|c|c|c|c|c|c|c|}
\hline \multirow{2}{*}{$\begin{array}{l}\text { Independent } \\
\text { variables }\end{array}$} & \multicolumn{2}{|c|}{ All firms } & \multicolumn{2}{|c|}{ Manufacturing firms } & \multicolumn{2}{|c|}{ Services firms } \\
\hline & $\begin{array}{l}\text { (1) } \\
\text { RE }\end{array}$ & $\begin{array}{l}(2) \\
\text { OLS }\end{array}$ & $\begin{array}{l}\text { (3) } \\
\text { RE }\end{array}$ & $\begin{array}{l}\text { (4) } \\
\text { OLS }\end{array}$ & $\begin{array}{l}(5) \\
R E\end{array}$ & $\begin{array}{l}\text { (6) } \\
\text { OLS }\end{array}$ \\
\hline \multirow[t]{2}{*}{ Size } & -0.088 & -0.080 & -0.044 & -0.016 & -0.128 & -0.098 \\
\hline & $(0.042)$ & $(0.021)$ & $(0.058)$ & $(0.031)$ & $(0.069)$ & $(0.034)$ \\
\hline \multirow[t]{2}{*}{ Total debt } & -2.244 & -2.223 & -3.107 & -3.065 & -1.614 & -1.480 \\
\hline & $(0.331)$ & $(0.139)$ & $(0.620)$ & $(0.269)$ & $(0.524)$ & $(0.198)$ \\
\hline \multirow[t]{2}{*}{ Short debt } & 1.271 & 1.337 & 0.403 & 0.563 & 0.966 & $1: 095$ \\
\hline & $(0.269)$ & $(0.120)$ & $(0.506)$ & $(0.229)$ & $(0.397)$ & $(0.182)$ \\
\hline \multirow[t]{2}{*}{$D_{\text {suineries }}$} & -0.194 & -0.228 & -0.234 & -0.332 & -0.121 & -0.182 \\
\hline & $(0.065)$ & $(0.067)$ & $(0.107)$ & $(0.110)$ & $(0.089)$ & $\begin{array}{l}(0.104) \\
-0.089\end{array}$ \\
\hline Share prices & $\begin{array}{l}-0.229 \\
(0.117)\end{array}$ & $\begin{array}{l}-0.148 \\
(0.099)\end{array}$ & $\begin{array}{l}-0.410 \\
(0.184)\end{array}$ & $\begin{array}{l}-0.208 \\
(0.163)\end{array}$ & $\begin{array}{l}-0.334 \\
(0.194)\end{array}$ & $\begin{array}{l}-0.089 \\
(0.153)\end{array}$ \\
\hline \multirow[t]{2}{*}{$D_{\text {stran }}$} & -1.438 & -1.427 & & & & \\
\hline & $(0.218)$ & $(0.098)$ & & & & \\
\hline$D_{s e r}$ & $\begin{array}{l}-0.695 \\
(0.217)\end{array}$ & $\begin{array}{l}-0.707 \\
(0.099)\end{array}$ & & & & \\
\hline \multicolumn{7}{|c|}{ PANEL B SUMMARY AND TEST STATISTICS ${ }^{2}$} \\
\hline \multirow{2}{*}{$\begin{array}{l}\text { Firms } \\
\text { Observations }\end{array}$} & 473 & 473 & 197 & 197 & 182 & 182 \\
\hline & 5676 & 5676 & 2364 & 2364 & 2184 & 2184 \\
\hline \multirow{2}{*}{$\begin{array}{l}\text { Order of integration } \\
\text { of liquidity targets } \\
\text { Order of integration } \\
\text { of errors }\end{array}$} & $\mathbb{I}(1)$ & I(1) & $\mathrm{I}(1)$ & I(1) & $I(1)$ & I(1) \\
\hline & $\mathbb{I}(0)$ & $\mathrm{I}(0)$ & $\mathrm{I}(0)$ & $\mathrm{I}(0)$ & $I(0)$ & $\mathrm{I}(0)$ \\
\hline
\end{tabular}

Notes: Random effects (RE) and ordinary least squares (OLS) estimates of Liquidity, defined as before. Standard errors are robust to heteroskedasticity (cf. White, 1982) and reported in parentheses.

$1 D_{\text {mintries }}$ is one for the years $1990-1997$ and zero otherwise, $D_{\text {man }}$ is one if the firm operates in the manufacturing sector and zero otherwise, $D_{s e r}$ is one if the firm operates in the services sector and zero otherwise. All other variables are defined as before.

2 We use $I(0)$ and $I(1)$ to signify that a series is integrated of order zero and one, respectively, using the Harris and Tzavalis (1999) test and a $95 \%$ level of confidence. 
The regression results for equation (5.1) are presented in table 5.2 . Comparing the random effects (RE) estimates with the ordinary least squares (OLS) estimates first of all suggests that our results are not particularly sensitive to the estimation method used. We will discuss the full sample results first and then generalise our findings to the separate sectors. Size captures any scale effect in liquidity management. The negative parameter estimate shows that liquidity increases less than proportional with size. This may result from portfolio effects, but can also indicate the ability of large firms to use their internal capital markets. In essence, the ability to reallocate funds internally across segments of the same firm is a substitute for precautionary liquidity holdings. ${ }^{16}$ Total debt and short debt capture the impact of leverage and debt maturity structure. Total debt carries a strong, significantly negative parameter estimate. The theoretical arguments discussed in section 5.2 suggest that this result captures creditors' monitoring efforts (cf. Diamond, 1991b) which may directly and indirectly reduce corporate liquidity holdings. Through the direct channel, monitoring reduces managerial discretion and hence lowers liquidity. Indirectly, monitoring may reduce information asymmetries and hence lower the risk premium on external finance, which reduces the corporate demand for precautionary liquidity. ${ }^{17}$

In the spirit of Diamond (1991a) we have included the short-term debt share in total debt (short debt) to characterise the debt maturity structure. The positive parameter estimate implies that for any given level of total debt, a larger short debt $(\approx$ shorter average maturity) increases liquidity. This effect lies probably closest to the refinancing uncertainty that we conjectured to have an impact on the informational cost of external finance. ${ }^{18}$

it Similarly, firms which actively use their internal capital markets may respond differently to informational problems in external capital markets in terms of their desired liquidity holdings. While we considen further exploration of this argument to be beyond the scope of the present analysis, it certainly is an interesting direction for future research.

17 The informational cost of external finance view would predict that higher leverage would increase the risk premium on external finance, rather than decrease it, since higher leverage implies that firms are closer to their debt capacity. The empirical results suggest that the negative monitoring effect on this risk premium outweighs the informational cost of external finance effect. Two additional explanations suggest that 1) higher leverage ratios indicate better historical access to debt and hence a reduced precautionary liquidity motive and/or 2) self-restraining management prefers not to concern its creditors with high levels of liquidity when leverage is high as well (cf. Myers and Rajan, 1998).

18. Note that increases in the level of short- and long-term debt alike have a negative impact on liquidity holdings. For an increase in long-term debt, through a higher total debt and lower short debr, this effect is unambiguous. For an increase in short-term debt, via a 
The macroeconomic environment plays an important role in corporate liquidity determination through share prices. Share prices relate negatively to liquidity. As we conjectured before, this might be explained by the reduced need for precautionary liquidity that stems from an economic environment where access to credit is relatively easy. ${ }^{19}$

The construction of the dummy variables $D_{\text {main }}, D_{\text {ser }}$, and $D_{\text {nineties }}$ is motivated by initial OLS estimates, which included dummies for each year and each sector. The intercept estimates for different manufacturing sectors were statistically insignificantly different from each other. The same holds for the services sector dummies. Collectively, manufacturing firms showed significantly lower intercept estimates than services firms. For reasons of parsimony, we have chosen to capture this pattern by the two dummies $D_{\operatorname{man}}$ and $D_{\text {ser }}{ }^{20}$ Similarly, individual year dummies reflected the downward trend in corporate liquidity observed from figure 5.1: all coefficients in the nineties were negative and those in the eighties were positive in the initial OLS estimates. The sharp turnaround in the values of these parameters from 1989 to 1990 motivates the inclusion of a single time dummy variable $D_{\text {nineties }}$, representing a one time downward shift in 1990.

Columns (3) to (6) show that the estimates are qualitatively similar across sectors. The sectoral differences pertain particularly to the total debt sensitivity. Liquidity in manufacturing firms is more sensitive to leverage and liquidity for services firms is less sensitive. In addition, there is no particularly strong size effect in liquidity holdings in manufacturing and the debt maturity structure short debt - seems to have a somewhat smaller impact. For services firms there is no clear distinction in the level of liquidity in the nineties relative to the eighties as shown by the insignificance of $D_{\text {nineties }}{ }^{21}$

negative effect through total debt and a positive effect through short debt, this result holds at sample means and given the parameter estimates in table 5.2.

19. However, one can also suspect that firms react opportunistically to such circumstances by raising funds for future use, hence adding to liquidity holdings. We discard this short-term behaviour in the determination of long-run liquidity targets. Unreported results furthermore show that the lending rate has a small and statistically insignificant coefficient, in line with empirical findings presented by De Haan et al. (1992).

20 The sector dummy for public utilities was insignificantly different from that of the manufacturing firms. In the final estimation, the dummy $D_{\text {man }}$ is used for utilities as well. The use of the restricted dummies leaves the other results qualitatively unchanged.

21 In addition to the general specification in table 5.2 , the long-run effect of liquidity substitutes has been explored by including near liquidity. We find no evidence that this variable impacts on long-run liquidity targets. 
Additionally, in panel $B$ of table 5.2 we report test results for the (non)stationarity of the estimated liquidity target on the one hand and the resulting residual on the other. For this purpose, we distinguish between the long-run corporate liquidity target $\hat{y}_{i t}^{g}=\hat{\beta}_{n} x_{i r}$ and the deviation from the target $\hat{\varepsilon}_{i t}^{\mathrm{g}}=\hat{\lambda}_{t}+\hat{\eta}_{i}+\hat{v}_{i t}$ (where hats indicate estimated values). According to this definition, we implicitly assume that the vector $x_{i t}$ captures all relevant information that firms use to set their targets. Firm (time)-specific elements in the error term are then interpreted as firm (time)-specific impediments to achieve convergence to these targets. For this reason, we label the target defined above as a global target.

We again use the Harris and Tzavalis (1999) technique discussed before. For liquidity targets we do not need to account for unit and time effects. We therefore evaluate the normalised least squares estimator of the autoregressive coefficient $(\varphi)$ in $y_{i t}=\varphi y_{i(t-1)}+\phi_{i t}$ where $y_{i t}=\hat{\beta} x_{i t}$. Again we test $H_{j}: \varphi$ $=1-$ at the $95 \%$ confidence level - versus the alternative $H_{a}: \varphi<1$ for which Harris and Tzavalis (1999) demonstrate that

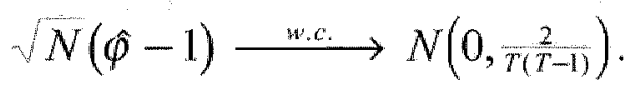

According to the results in panel $\mathrm{B}$, liquidity targets have a unit root. This holds for the whole sample, as well as for the manufacturing and services sectors separately. To test for the nonstationarity of the residual, we apply the same test as used in table 5.1, including the possibility of fixed effects and a time trend. According to this test, the residual series are stationary. Hence we conclude that liquidity is cointegrated with liquidity targets so that the use of an error correction framework to characterise corporate liquidity dynamics is justified. ${ }^{22}$

Alternatively, we may assume that the firm's liquidity target includes the estimated firm- and time-specific effects. Then, the specific target is defined as $\hat{y}_{i t}^{s}=\hat{\beta}_{n}^{\prime} x_{i t}+\hat{\lambda}_{p}+\hat{\eta}_{i}$, while the deviation from the target is given by $\hat{\varepsilon}_{i t}^{s}=\hat{v}_{i t}$. The firm- and time-specific elements in the liquidity targets then refer to elements in (precautionary) liquidity demand not captured by the $x_{i f}$. Regarding firm-specific elements, we do not control, for instance, for the ownership structure of the firm or the extent to which the firm has access to emergency lines of credit. Especially the part of liquidity targets that is motivated by firm-specific information problems may be opaque, so that the

22 This is an indirect test on cointegration, disregarding for instance the cointegrating relationships that may exist among the $x_{i j}$. Direct, multivariate tests on cointegration, however, usually require $T \rightarrow \infty$ for consistency (see Baltagi and Kao, 2000, or Banerjee, 1999). 
inclusion of the firm-specific effects controls for unobserved cross-sectional heterogeneity in that regard. ${ }^{23}$

In the dynamic error correction specification we will use either the global or specific estimated residual as defined above to capture the deviation from target.

\subsubsection{The determination of corporate liquidity dynamics}

For the remainder of this section, we shift our attention from the determination of long-run liquidity levels to the short-run dynamics of corporate liquidity holdings. The empirical dynamic liquidity regression equation looks as follows:

$$
\Delta y_{i t}=\beta_{l r}^{\prime} \Delta x_{i t}+\gamma \hat{\varepsilon}_{i(t-1)}^{z}+\beta_{s r}^{\prime} x_{i t}^{S R}+\lambda_{t}^{*}+\eta_{i}^{*}+v_{i t}^{*}
$$

where $\Delta y_{i t}$ denotes $y_{i t}-y_{i(t-1)}$ and $y$ again represents liquidity. Time- and unit-specific random effects are captured by $\lambda_{i}^{*}$ and $\eta_{i}^{*}$, respectively. $\Delta x_{i t}$ and $x_{i t}^{S R}$ stand for vectors of explanatory variables where the former indicates the vector of first-differenced long-run determinants of corporate liquidity and the latter represents short-run liquidity dynamics triggered by cash flow and investment. Lastly, $\hat{\varepsilon}_{i(t-1)}^{z}$ with $z \in\{g, s\}$ indicates that the global or specific target has been imposed while the error correction parameter $\gamma$-required to be negative for dynamic stability - represents the speed of adjustment towards the long-run target.

Since lagged liquidity enters on the right-hand side of the regression equation and we model a firm-specific random error component, we have to consider and correct for the correlation between lagged liquidity and the regression error. We use the Arellano and Bond (1991) dynamic panel estimation methodology to compute consistent parameter estimates. ${ }^{24}$

Table 5.3 presents the regression results comparing restricted error correction estimates where global and specific targets have been imposed

23 Separate unit root tests on the specific target and residual lead to the same conclusion as for their global counterparts: nonstationarity cannot be rejected for the target, while it can for the residual.

24 In the absence of serial correlation, our assumption regarding the properties of the error term are valid and inference from our estimates is appropriate. Within the Arellano and Bond framework, we test for the absence of second order serial correlation to check our dynamic specification. 


\section{Table 5.3}

Restricted error correction estimates of corporate liquidity

\begin{tabular}{|c|c|c|c|c|c|c|}
\hline $\begin{array}{l}\text { Independent } \\
\text { variables }\end{array}$ & $\begin{array}{l}\text { (1) } \\
\text { All }\end{array}$ & $\begin{array}{l}\text { (2) } \\
\text { Al] }\end{array}$ & $\begin{array}{l}\text { (3) } \\
\text { Man }\end{array}$ & $\begin{array}{l}\text { (4) } \\
\text { Man }\end{array}$ & $\begin{array}{l}\text { (5) } \\
\text { Ser }\end{array}$ & $\begin{array}{l}\text { (6) } \\
\text { Ser }\end{array}$ \\
\hline $\begin{array}{l}\text { Cash flow, } \\
\text { Investment, } \\
\text { Deviation from } \\
\text { global larget } \\
\text { Deviation from } \\
\text { specific target }\end{array}$ & $\begin{array}{c}0.231 \\
(0.117) \\
-1.023 \\
(0.204) \\
-0.114 \\
(0.014)\end{array}$ & $\begin{array}{c}0.335 \\
(0.113) \\
-0.912 \\
(0.186) \\
\\
-0.824 \\
(0.059)\end{array}$ & $\begin{array}{l}0.337 \\
(0.194) \\
-1.963 \\
(0.367) \\
-0.138 \\
(0.021)\end{array}$ & $\begin{array}{c}0.557 \\
(0.186) \\
-1.770 \\
(0.329) \\
\\
-0.849 \\
(0.067)\end{array}$ & $\begin{array}{l}0.303 \\
(0170) \\
-0.561 \\
(0.272) \\
-0.122 \\
(0.017)\end{array}$ & $\begin{array}{l}0.304 \\
(0.169) \\
-0.454 \\
(0.229)\end{array}$ \\
\hline \multicolumn{7}{|c|}{ PANEL B SUMMARY AND TEST STATISTICS ${ }^{2}$} \\
\hline $\begin{array}{l}\text { Firms } \\
\text { Observations }\end{array}$ & $\begin{array}{r}473 \\
4257 \\
\end{array}$ & $\begin{array}{r}473 \\
4257\end{array}$ & $\begin{array}{r}197 \\
1773\end{array}$ & $\begin{array}{r}197 \\
1773\end{array}$ & $\begin{array}{r}182 \\
1638\end{array}$ & $\begin{array}{r}182 \\
1638\end{array}$ \\
\hline $\begin{array}{l}\text { Joint significance } \\
\text { Sargan } \\
\text { SOSC }\end{array}$ & $\begin{array}{r}x^{2}(3)= \\
102.3^{40} \\
\chi^{2}(16)= \\
21.2 \\
-0.816\end{array}$ & $\begin{array}{r}x^{2}(3)= \\
230.8^{*} \\
x^{2}(1.6)= \\
23.8 \\
1.331\end{array}$ & $\begin{array}{r}\chi^{2}(3)= \\
81.0^{* *} \\
\chi^{2}(16)= \\
12.9 \\
0.596\end{array}$ & $\begin{array}{r}\chi{ }^{2}(3)= \\
230.6 \\
\chi^{2}(16)= \\
15.3 \\
1.209\end{array}$ & $\begin{array}{r}\chi^{2}(3)= \\
63.9^{* *} \\
\chi^{2}(16)= \\
21.0 \\
-2.647^{\circ *}\end{array}$ & $\begin{array}{r}x^{2}(3)= \\
94.9^{3 *} \\
x^{2}(16)= \\
21.9 \\
0.071\end{array}$ \\
\hline
\end{tabular}

Notes: Random effects estimates of $\Delta$ Liquidity, where Liquidity is defined as before Standard errors are robust to heteroskedasticity (cf. White, 1982) and reported in parentheses. "All" indicates that the full sample of firms was used in the estimation, "Man" ("Ser") indicates that only manufacturing (services) firms are used.

1 Deviation from $[. .$.$] target t_{t-1}$ is the regression error extracted from the random effects estimates reported in table 5.2, columns (1) (all firms), (3) (manufacturing firms), and (5) (services firms). Global and specific targets are defined in the text. All other variables are defined as before. $\Delta$ denotes the first difference with respect to time. Liquidity $_{t-1}$ is instrumented with its own level lagged another period (i.e. Liquidity ${ }_{k-2}$ ). Deviation from [...] rarget ${ }_{f-1}$ is instrumented with its own level lagged another period. Investment is treated as a potentially endogenous variable and is instrumented with its own level lagged one period.

2 Joint significance for all variables in the model is tested with a Wald test. Sargan refers to the Sargan test for overidentifying restrictions and is also heteroskedasticityconsistent (cf. Arellano and Bond, 1991). SOSC test for second order autocorrelation and is based on estimates of the residuals in first differences (cf. Arellano and Bond, 1998). Significance at the 5 and $\mathbb{1}$ percent error level is indicated by "and , respectively. 
alternately. ${ }^{25}$ These results are presented for all firms together, as well as for manufacturing and services firms separately. In this restricted empirical counterpart of equation (5.2), the short-run dynamics are represented by the inclusion of cash flow and investment only (no lags of changes in liquidity were needed for dynamic validity of the equation) in addition to the gradual reversion to the long-run target.

The gradual reversion to long-run liquidity targets is reflected by the negative impact of deviations from these targets on current liquidity dynamics. Imposing the global targets (columns (1), (3), and (5)) produces a 10 percent rate of convergence per year to the long-run target. The speed of adjustment implied by these estimates is quite low. Two explanations of this result are possible.

First, assuming the long-run targets are measured accurately, the observed speed of adjustment suggests that these targets do not play a very important role in a firm's liquidity management. As a corollary, it suggests that actual liquidity developments over periods of several years may resemble the picture that would emerge under pecking-order behaviour. ${ }^{26}$ Second, the targets may be measured inappropriately, for instance because the global target neglects the unspecified part of each firm's target as captured by the firm- and timespecific random effects. These are included in the specific targets to which we now turn. Columns (2), (4), and (6) indeed show that the speed of adjustment increases considerably when we use specific liquidity targets. We now observe convergence at a rate of more than 80 percent per year. This holds for both the services and the manufacturing sectors. In comparison with the global target results; these findings stress the importance of micro-data analysis in the analysis of liquidity targets and especially target adjustment, since the error correction effort is likely to be seriously under-estimated when the data are analysed at a higher level of aggregation. Here, the link with many macroeconomic studies of money demand is easily made. There, an implausibly low speed of adjustment is often found as well, see for instance Goldfeld and

25. Alternatively, we have estimated a non-restricted version of equation (5.2) where all long-run determinants of the level of liquidity have been included separately. The implied long-run coefficients from an unrestricted estimation of equation (5.2) are broadly similar to the direct estimates of long-run liquidity determinants as presented in table 5.2. Moreover, the resulting estimates on short-run dynamics are very similar to those obtained from the restricted estimation presented in table 5.3.

26 Shyam-Sunder and Myers (1999) make a similar point for capital structure adjustment. 
Sighel (1990). Swamy, Tinsley, and Moore (1982) already suggest that aggregation problems may be the cause of these results. ${ }^{27}$

In addition, the dynamic specification allows for an investigation of the importance of flow of funds variables that are advocated by the pecking order theory such as cash flow and investment. We find cash flow to affect the change in liquidity positively. Investment has a negative effect. ${ }^{28}$ Both effects are in line with buffer stock behaviour in a long-run target framework as well as with the pecking order line of reasoning. The magnitude of the effect is relatively insensitive to the use of global or specific targets. The significance tends to increase when specific targets are used, providing an additional motive to prefer this specification.

However, the absolute magnitude of the effects is low, indicating that the major part of cash flow is not passively added to liquidity. Neither is investment predominantly financed by internal liquid assets. For instance, in an absolute sense - given an average corporate liquidity ratio of $3.1 \%\left(=e^{-3.480}\right.$, see table 5.1) and the parameter estimates in column (1) - we conclude that for every guilder worth of investment spending, holdings of liquid assets are reduced by only about 3 cents. ${ }^{29}$ Note that manufacturing firms' liquidity holdings are more sensitive to investment expenditures than is the case for services firms. Comparing columns (3) and (5), a guilder increase in investment spending reduces holdings of liquid assets by some 4 cents for manufacturing firms and by only slightly more than 2 cents for services firms (the average liquidity ratio is 2.2 percent for manufacturing firms and 3.4 percent for services firms).

The quantitative effect of a one guilder increase in cash flows is even less. For all firms jointly, the effect is approximately 1 cent. In absolute terms, the sensitivity of manufacturing firms and services firms is about equal. The

27 Part of the firm-specific effect may still capture the structural inability of the firm to make required adjustments to the target. To that extent, we may mis-measure the target and over-estimate the adjustment speed.

28. We have also considered some extensions to the dynamic liquidity equation. Some (unreported) findings in this regard are that the impact of changes in total debt and changes in near liquidity are not statistically significant. The short-run responsiveness of liquidity to changes in the opportunity costs of holding liquidity was also examined by adding the change in the lending rate. These changes affected dynamic liquidity negatively, but insignificantly. The same result was found for changes in share prices.

29 The absolute impact of a guilder worth of investment spending on changes in holdings of liquid assets is equal to the estimated parameter on investment multiplied by the exponent of average liquidity. 
higher estimated coefficient for manufacturing firms is approximately offset by the lower average liquidity ratio.

Our liquidity results sharply contrast with the capital structure results obtained by Shyam-Sunder and Myers (1999). They find relatively slow and unimportant target adjustment in combination with an almost one-to-one effect of flow-of-funds variables on changes in net or gross debt. Our results are just the opposite, with substantial target adjustment. The evidence thus suggests that liquidity and debt are far from perfect substitutes and throws doubt on the net debt hypothesis. Our results also do not confirm the hypothesis put forward by Dittmar et al. (2003) that the low shareholder rights in the Netherlands lead to excessive liquidity holdings. In contrast, we find relatively low liquidity holdings in the Netherlands, which is similar to the results that Pinkowitz and Williamson (2001) obtain for Germany as well as for the US. We also find that long-run liquidity determinants like firm size and leverage affect Dutch corporate liquidity holdings in much the same way as Opler et al. (1999) report for US firms. Hence differences in the organisation of the market-based US financial system and the predominantly bank-based Dutch financial system are not readily visible from the analysis of corporate liquidity determination.

\subsection{Summary and conclusions}

In this chapter, we empirically investigate the determinants of corporate liquidity holdings in the Netherlands. We contribute to the current literature in two ways. First, we add to the scarce empirical evidence using a new highquality data set for a sample of large non-financial firms operating in the predominantly bank-based Dutch financial system. An important characteristic of these data is their consistent availability over a period of twelve years. As a consequence, the data allow for a panel approach, combining cross-sectional and time characteristics of corporate liquidity holdings. This relates to the second innovative element in our research: we are able to distinguish both theoretically and empirically between long-run and short-run determinants of corporate liquidity holdings. To this purpose, we hypothesise an error correction framework for the empirical analysis.

Our empirical analysis provides clear evidence for the existence of longrun corporate liquidity targets. These long-run liquidity targets are important not only in explaining liquidity levels, but also stand out in the explanation of (short-run) dynamic liquidity in an error correction framework. In conjunction with target adjustment, we find some evidence of short-run liquidity behaviour that appears to be in line with a buffer stock line of reasoning. In particular, a firm's investment expenditures and cash flow have a meaningful impact on its 
liquidity holdings. These results are observationally equivalent with the pecking order implications regarding corporate liquidity dynamics. However, the absolute size of these effects is modest on average and does not extend to the long run. Hence we interpret them within our empirical model as short-run volatility around a long-run liquidity target.

The speed of adjustment towards the targets depends on the exact elements we include in the specification of the long-run targets. In particular, if unobserved heterogeneity across firms and years is not accounted for in the sensitivity of firms to informational problems - and hence the computation of the targets - we document a 10 percent rate of convergence to the target. This figure compares well with results obtained from macro-studies of money demand. Alternatively, we take into account that a considerable part of the liquidity decision may result from unobservable firm- and time-specific considerations. In this case we find an annual rate of convergence to target exceeding 80 percent, well in excess of the 10 percent that is usually obtained in macro-studies. Our results point to aggregation problems in macroeconomic demand for money studies.

We conclude that the corporate liquidity ratio is an actively managed financial ratio and does not passively adjust to financial decisions taken elsewhere in the firm. Based on long-run evidence, a pecking order theory of corporate liquidity holdings must be rejected. 


\section{Chapter 6 \\ The Urgency of Corporate Liquidity Adjustment}

\subsection{Introduction}

The previous chapter demonstrates that firms specify long-term liquidity targets and make efforts even in the short run to obtain convergence towards these targets. The presence of a long-run target is motivated by a static trade-off argument for liquidity holdings. Transactions demand for liquidity, opportunity costs, and precautionary liquidity demand due to the existence of asymmetric information problems all contribute to a static cost-benefit analysis of optimal liquidity holdings. In the short run, however, liquidity additionally responds passively to current (cash flow) developments as consistent with the predictions of the buffer stock approach in macroeconomics and the pecking order theory in finance. An explanation for the observed difference between the short-run and long-run process of liquidity determination was offered in terms of adjustment costs. Particularly in line with the buffer stock approach, we have assumed that liquidity adjustment is the least costly short-run adjustment alternative anong the total range of a firm's financial adjustment decisions in a given year. Given this assumption, for a profit maximising firm it is optimal to have liquidity holdings bear the burden of adjustment in the short run and hence have these holdings passively accommodate postponed adjustment in other financial balance items like debt or equity. Only over a somewhat longer horizon, convergence towards the longer-run liquidity target gains in importance.

We should realise, however, that liquidity need not be the least costly short-run adjustment option for a firm in every year. Cast in terms of our findings in the previous chapter: short-run liquidity holdings need not always reflect passive responsiveness to developments in cash flow and investment. Depending on the marginal evaluation of deviations from the target, the importance of liquidity adjustment may rise relative to other financial balance items even in the very short run. Put differently, specific conditions may cause a short-run adjustment of the corporate liquidity ratio to be more urgent than for example an adjustment in the firm's capital stock. It is important to know under what conditions the relative importance of liquidity adjustment rises for the proper analysis of spill-overs from the liquidity decision to other financial (e.g., capital structure) as well as real (e.g., capital stock) corporate decisions. By demonstrating that liquidity adjustment gains in importance under specific 
conditions, we also mark the situations where other corporate decisions are made subject to an adjustment of contemporary liquidity to its targeted level.

This chapter therefore aims to identify the specific conditions that make adjustment of corporate liquidity to targeted levels most urgent. ${ }^{1}$ We stress in this regard the marginal cost-benefit structure of the corporate liquidity decision and the derived adjustment incentives. Our particular aim is to get a better insight in the extent to which liquidity adjustment incentives are dependent on the sign and size of the deviation from the liquidity target and the dynamic implications thereof. Regarding the latter, we expect conditional adjustment incentives to translate into a conditional and perhaps asymmetric speed of target adjustment.

Consider the following two illustrations of adjustment speed asymmetries. First, let us assume that liquidity shortages are more costly than surplus liquidity holdings. A theoretical motivation may run along the lines of higher liquidation risk when liquidity falls short of the target. These conditional liquidity adjustment incentives - ceteris paribus - raise the relative importance of liquidity adjustment among the range of a firm's financial adjustment decisions when liquidity levels fall short of the targets. Hence we may hypothesise an asymmetric adjustment response to deviations of different sign, with faster adjustment when they are negative, i.e. the firm starts with a shortfall of liquidity relative to the target. Second, let us assume that liquidation risk increases when liquidity falls farther short of the target. Then, large shortfalls of liquidity are more costly than small ones and consequently adjustment incentives are stronger when liquidity falls farther short of the target. We may then hypothesise asymmetric adjustment responses to deviations of different size, with liquidity adjustment being faster when the starting point lies further below the target. Of course, adjustment asymmetries related to the size of the initial deviation may also pertain to positive deviations from the target. In a broader context therefore, adjustment conditional on the size of the deviation addresses whether there is a band of inactivity - non adjustment - when a firm's liquidity holdings are within a narrow range from the target and whether firms only take corrective action when the gap between actual and optimal liquidity holdings gets too wide.

Related Dutch research in this field by De Haan, Koedijk, and De Vrijer (1994) and De Haan (1997) relies on qualitative results from a survey questionnaire conducted among 1,800 firms in 1991. The findings suggest some indication of liquidity adjustment being faster in an upward than in a downward

"We exploit this information in chapter 7 to examine the impact of the corporate liquidity decision on the connection between investment and finance. 
direction. We contribute to this literature by using high-quality data on the finances of large Dutch firms for the period 1986-1997. This allows us to characterise the liquidity decision more comprehensively and specifically exploit the variation of target deviations and adjustment speeds over time, providing testable hypotheses regarding differential speed of liquidity adjustment conditional on the sign and size of the deviation.

The organisation of the chapter is as follows. In section 6.2 we discuss theoretical motivations for the existence of asymmetries in liquidity adjustment. The emphasis is on the constellation of marginal costs and benefits of liquidity holdings. In section 6.3 we briefly re-introduce the construction of liquidity targets and deviations and outline our empirical strategy. Liquidity adjustment dependent on the sign and size of the deviation is then assessed in sections 6.4 and 6.5 , respectively. Section 6.6 summarises and concludes.

\subsection{Conditional adjustment incentives}

The maintained hypothesis throughout this chapter is that the observed rate at which liquidity is adjusted towards the target accurately reflects the firm's adjustment incentives. We characterise these adjustment incentives, $\Pi$ (Adjust), as a non-decreasing function of the discrepancy between marginal costs $(M C)$ and marginal benefits $(M B)$ of corporate liquidity holdings: $\Pi(A d j u s t)=f(M B-$ $M C$ ). In line with the static cost-benefit analysis outlined in the previous chapter, these marginal costs and benefits are functions of the level of liquidity holdings. As such, when a firm's liquidity holdings are exactly on target, adjustment incentives are zero, i.e. the marginal cost of holding one more unit of liquidity equals its marginal benefit. Also, a positive discrepancy indicates that liquidity is below its targeted level and - by $\Pi$ (Adjust) - provides an incentive to raise hiquidity holdings, while an incentive to lower liquidity holdings is indicated by a negative discrepancy. Our focus on adjustment incentives conditional on the sign or the size of the target deviation stresses the respective shapes of the marginal cost and benefit curves of liquidity holdings, to which we now turn.

To start we assume a constellation of marginal costs and benefits of liquidity as shown in figure 6.1 , where marginal costs (benefits) of liquidity are increasing (decreasing) in the level of liquidity holdings. From the fugure it is clear that asymmetric adjustment incentives relating to the sign of the deviation are absent: it is equally beneficial to raise liquidity holdings from a position such as 'negative" ("low') as it is costly to maintain a liquidity position such as "positive' ('high'). At the same time, however, adjustment incentives are very clearly conditional on the size of the deviation: the adjustment incentive from a 


\section{Figure 6.1}

Symmetry in sign, asymmetry in size

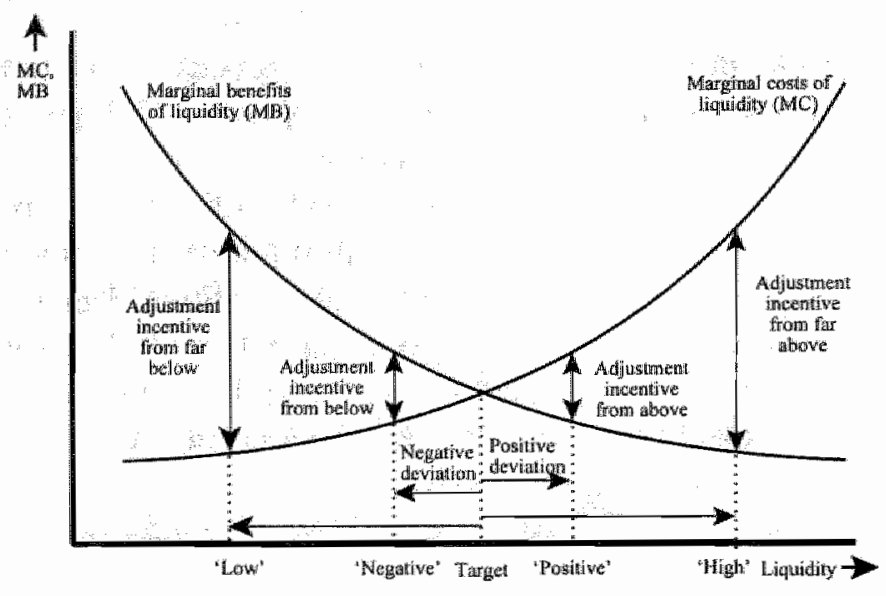

moderately low (high) liquidity position such as 'negative' ('positive') is less than that for adjustment from a lower (higher) position such as 'low' ('high'). Given this structure of marginal costs and benefits of liquidity holdings, we expect to find faster adjustment of liquidity to target when the starting point is farther away from the target, but we do not expect the initial sign of the deviation to affect the adjustment speed.

Alternatively, Opler, Pinkowitz, Stulz, and Williamson (1999) determine the optimal level of liquidity holdings from a graph similar to figure 6.2 . In this figure the marginal cost of holding liquidity is assumed to be unrelated to the level of liquidity held by the firm. Such a representation assumes, for instance, that the only cost the firm incurs from holding liquid assets is the foregone internal rate of return at which these funds could have been invested. ${ }^{2}$ The marginal benefit of liquidity is plotted as a decreasing function of the level of corporate liquidity. The underlying economic intuition is that the cost of liquidity shortage - and hence the benefit of an additional unit of liquidity - is highest (due to costly liquidation in particular) when holdings of liquid assets are low. The marginal benefit of liquidity decreases in the level of liquidity, but liquidity is always non-negatively valued, so that the marginal benefit curve

2 In a world of perfect capital markets, this equals the rate at which the firm obtains funds in the market. However, Opler et al. (1999) and Kim et al. (1998) for example explain that the explicit motivation to demand a positive amount of liquidity assumes that there are frictions in capital markets that likely drive a wedge between the internal rate of return of corporate investment and the market interest rate against which borrowing and lending is done. 


\section{Figure 6.2}

Asymmetry in sign as well as size

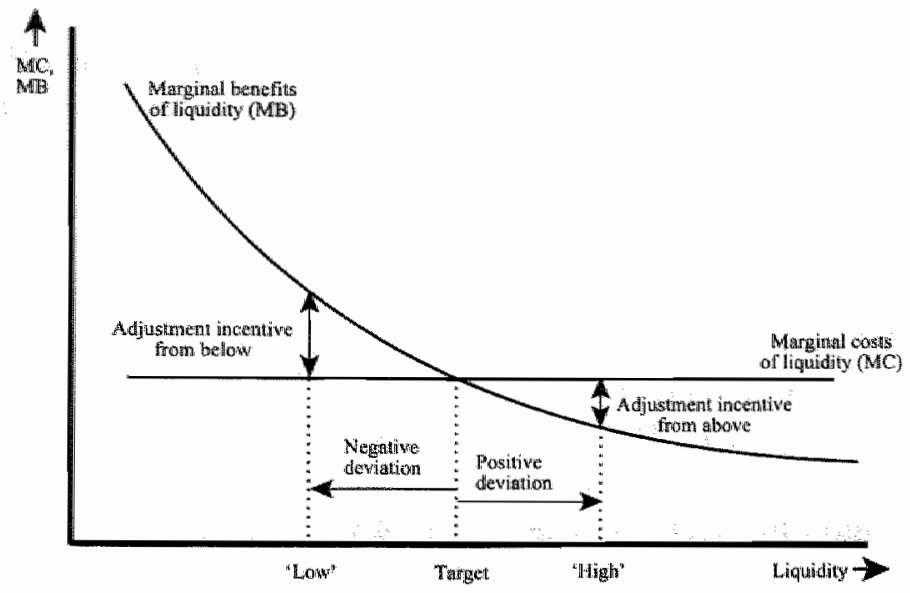

never intersects with the horizontal axis. Put together, the setup provides a distinct case for adjustment incentives that are conditional on the sign of the deviation. This results directly from the assumption that the marginal benefit from holding liquidity rises faster when liquidity falls from 'target' to 'low' than that it falls when liquidity rises from 'target' to "high". Hence the incentives to adjust are stronger and the expected speed of adjustment is higher for adjustment from below the target. ${ }^{3}$ At the same time, we observe from the figure that adjustment incentives are also conditional on the size of the deviation. However, this conditionality is less pronounced (and actually limited in an absolute sense) for positive than for negative deviations: the adjustment incentive increases rapidly when we move farther below the target, whereas it levels out when we move farther above the target. These incentives therefore also support the notion that asymmetries relating to the sign of the deviation are especially pronounced when the size of the deviation becomes larger.

The relevant question therefore concerns the respective shapes of the marginal cost and benefit curves. First, we explore the possible shapes of the marginal cost of liquidity curve. To the extent that these costs reflect opportunity costs only, there is no clear reason why they would be related to the level of liquid asset holdings. Increasing marginal costs must therefore be motivated differently, for instance by take-over candidacy or through the costs of acquiring external finance. The take-over candidacy argument states that

3 Of course, when the marginal benefit is less responsive to the level of liquidity around the target than is the marginal cost, the asymmetry might also work in the other direction, predicting faster liquidity adjustment from above the target. 
cash-rich firms are attractive candidates for hostile take-over bids (e.g., Brealey and Myers, 1996; Boot and Verheyen, 1997). ${ }^{4}$ The perceived expected cost of a hostile take-over and consequently of high liquid asset holdings may be considerable from the perspective of the management. The argument related to the acquisition of external finance is that debt may be more expensive - if available at all - for firms with high levels of liquidity holdings. Myers and Rajan (1998), for example, reason that creditors may have a dislike for overly liquid debtors since this increases the possibility that assets are diverted away from them. ${ }^{5}$ However, these additional costs of liquidity may be relevant for relatively high levels of liquidity only. For moderate levels of liquidity, the marginal cost may still be quite unrelated to the liquidity level, yielding a relatively flat marginal cost curve over the relevant range of liquidity holdings. ${ }^{6}$

Second, we discuss whether the marginal benefit may be expected to depend negatively on the liquidity level. The main argument in this regard is the risk of costly liquidation when liquidity decreases. Milne and Robertson (1996), for instance, model the corporate liquidity decision as a trade off between the desire to pay dividends to appease shareholders on the one hand and the incentive to build a buffer of liquid assets to mitigate the liquidation risk on the other. An important result of their model is "that local risk-aversion is a decreasing function of cash held internally, that is, the firm is most risk-averse when it is closest to liquidation" (p. 1429). Milne and Robertson therefore predict that liquidity adjustment is predominant in the set of corporate financial goals when liquidity is particularly far below target. Using a similar setup, Mahu] (2000) concludes that "[u]nder [the] threat of liquidation, the riskneutral producer is shown to [...] exhibit first-order risk aversion" (p. 49). In a more general setting, Bolton and Freixas (2000) argue that firms turn to banks for loans mainly because banks are good at helping them through bad times. Fear of costly liquidation produces an equilibrium in their model in which riskier firms prefer (costly) bank loans and safer firms turn to the market for

4 The attractiveness as a take-over candidate may stem directly from the attractiveness of the stock of hiquidity, but may also indirectly result from the fact that stock markets value high liquidity negatively (as an indicator of under-investment, for instance) so that a firm"s shares trade at a sufficient discount to incite a take-over bid.

5 In similar vein, Hege and Mella-Barral (2000) establish that the perceived ex post relative bargaining power of the debtor is a major determinant of the debt capacity of the firm, which creditors determine ex ante. See also Mella-Barral (1999).

6 To the extent that the marginal costs become more sensitive to the level of liquidity at very high levels of liquidity, the asymmetry in adjustment incentives relating to the size of the deviation is reduced and may even be nullified. See also footnote 3 . 
finance. This all implies quite straightforwardly that the marginal valuation of liquidity increases when the level of liquidity decreases. Opler and Titman (1994) furthermore demonstrate that firms have a need for precautionary internal finance to reduce the potential cost of foregone investment opportunities. ${ }^{7}$ This argument also supports the notion that marginal benefits of liquidity holdings increase when liquidity holdings decrease.

If indeed - for relatively normal levels of liquid assets holdings - the marginal cost curve is relatively flat, while the benefits are concave in liquidity holdings, there are theoretical reasons to assume asymmetries in the adjustment of liquidity towards targets. On the one hand, there is the suggestion of faster upward than downward adjustment. ${ }^{8}$ On the other hand, we then expect such asymmetries to be more pronounced when the size of the deviation increases. In the remainder of this chapter, we investigate the issue of asymmetric liquidity adjustment empirically.

\subsection{The empirical strategy}

For the empirical characterisation of corporate liquidity targets, we use the analysis of long-run liquidity levels as introduced in section 5.4. The estimates used for the creation of liquidity targets derive from a balanced panel of 473 firms for the period 1986-1997 and are presented in table 6.1. We refer to chapter 5 for a detailed analysis of the economic importance of the included variables as well as a discussion of the data. Note that throughout the chapter variable names are again in italics.

We compute the predicted values from these estimation results and include the estimated firm- $\left(\hat{\eta}_{i}\right)$ and time-specific $\left(\hat{\lambda}_{t}\right)$ random effects to arrive at the (firm- and time-) specific corporate liquidity target

(6.1) $\rho_{i t}^{s}=\hat{\beta}_{n}^{\prime} x_{i t}+\hat{\lambda_{i}}+\hat{\eta}_{i}$,

where $y$ denotes liquidity and $x_{i t}$ and $\hat{\beta}_{n}$ represent the vectors of explanatory variables and estimated coefficients, respectively, reported in table 6.1. The

? Specifically, they find that firms face an additional cost of financial distress in the form of (competitor driven) lost market share and reduced performance.

With marginal costs of liquidity possibly becoming (more) sensitive to changes in liquidity at very high levels of liquidity, this asymmetry relating to the sign of the deviation possibly becomes less pronounced when exceptionally large deviations are considered. 


\section{Table 6.1}

Level estimates of corporate liquidity: base case results, 1986-1997

\begin{tabular}{|c|c|c|c|}
\hline Independent wariables & (1) & $\begin{array}{l}\text { (2) } \\
\text { Man }\end{array}$ & $\begin{array}{l}\text { (3) } \\
\text { Ser }\end{array}$ \\
\hline $\begin{array}{l}\text { Size } \\
\text { Total debt } \\
\text { Short debt } \\
D_{\text {mirretiles }} \\
\text { Share prices } \\
D_{\text {man }} \\
D_{\text {ser }}\end{array}$ & $\begin{array}{l}-0.088 \\
(0.042) \\
-2.244 \\
(0.331) \\
1.271 \\
(0.269) \\
-0.194 \\
(0.065) \\
-0.229 \\
(0.117) \\
-1.438 \\
(0.218) \\
-0.695 \\
(0.217)\end{array}$ & $\begin{array}{c}-0.044 \\
(0.058) \\
-3.107 \\
(0.620) \\
0.403 \\
(0.506) \\
-0.234 \\
(0.107) \\
-0.410 \\
(0.184)\end{array}$ & $\begin{array}{c}-0.128 \\
(0.069) \\
-1.614 \\
(0.524) \\
0.966 \\
(0.397) \\
-0.121 \\
(0.089) \\
-0.334 \\
(0.194)\end{array}$ \\
\hline $\begin{array}{l}\text { Finms } \\
\text { Observations }\end{array}$ & $\begin{array}{r}473 \\
5676\end{array}$ & $\begin{array}{r}197 \\
2364\end{array}$ & $\begin{array}{r}182 \\
2184\end{array}$ \\
\hline
\end{tabular}

Notes: Random effects estimates of Liquidity, defined as the logarithm of cash and marketable securities over net assets; net assets is total assets less cash and marketable securities. Standard errors are robust to heteroskedasticity (cf. White, 1982) and reported in parentheses. "All" indicates that the full sample of firms was used in the estimation, "Man" ("Ser") indicates that only manufacturing (services) firms are used.

1 Size is the logarithm of net assets expressed in 1990 prices; Total debt is defined as total debt over total assets; Short debt expresses short-term debt as fraction of shortand long-term debt: $D_{\text {minerex }}$ is one for the years 1990-1997 and zero otherwise; Share prices is the general index reported in the IFS of the IMF; $D_{\operatorname{man}}$ is one if the firm operates in the manufacturing sector and zero otherwise; $D_{\text {ser }}$ is one if the firm operates in the services sector and zero otherwise.

inclusion of the firm- and time-specific effects controls for unobserved heterogeneity in corporate liquidity determination.

Subsequently, the deviations of corporate liquidity from the specific target $\left(\hat{\varepsilon}_{i z}^{s}=y_{i t}-\hat{y}_{i t}^{s}\right)$ are included in the short-run, dynamic liquidity equation in conjunction with other short-run driving forces of corporate liquidity. In a general form, the analysis of target adjustment asymmetries evaluates

(6.2) $\Delta y_{i t}=\beta_{l}^{\prime} x_{i t}^{S R}+\sum_{d} \gamma_{d} D^{d} \hat{\varepsilon}_{i(t-1)}^{s}+\lambda_{t}^{*}+\eta_{i}^{*}+v_{i t}^{*}$,

where $\Delta y$ denotes the first difference of liquidity, $x_{i t}^{S R}$ the vector of short-run determinants with coefficient vector $\beta_{l}, \lambda_{t}^{*}$ and $\eta_{i}^{*}$ are time- and unit-specific 
random effects, respectively, and $v_{i t}^{*}$ is a white-noise error term with the usual properties. The focus of the analysis for the remainder of this chapter is on $\gamma_{d} D^{d} \hat{\varepsilon}_{i(t-1)}^{s}$, which denotes the partitioned error correction. Here $\gamma_{d} \hat{\varepsilon}_{i(i-1)}^{s}$ captures the target adjustment that is conditional on the dummy $D^{d}$ being 1 : $D^{d}$ is a dummy variable that characterises the beginning-of-period target deviation in terms of direction or magnitude and $\gamma_{d}$ is the associated conditional - adjustment speed.

The conditional target adjustment results are presented in two parts. First, in section 6.4 we look into the asymmetries in adjustment related to the sign of the deviation. Then, in section 6.5 we investigate whether the size of the deviation matters.

\subsection{Does sign matter?}

We first examine whether the target adjustment speed is different for adjustment in an upward than for adjustment in a downward direction, i.e. is adjustment conditioned by the sign of the initial gap between liquidity holdings and the target?

Let us first briefly discuss the reference situation of unconditioned target adjustment. In table 6.2 , the relevant estimation results - repeated from table 5.3 - are presented for all firms as well as for manufacturing firms and services firms separately (columns (1), (3), and (5)). In all three instances, the significantly negative sign on deviation indicates that long-run target adjustment is relevant even in the short run. Firms that start a year with a surplus of liquidity relative to the long-run target significantly run down their liquid asset holdings during that year and vice versa. In all three instances - all else equal approximately eighty percent of the deviation is removed in a single year.

In addition to target adjustment, however, liquidity dynamics are also sensitive to current developments, the $x_{i t}^{S R}$ in equation (6.2). In particular, the positive (negative) sign on cash flow (investment) indicates that in the short run buffer stock behaviour is relevant as well: sources of funds tend to be added to liquidity and uses of funds tend to be extracted (e.g., De Haan et al., 1994; Ireland and Wren-Lewis, 1992). The impact of cash flow and investment on dynamic liquidity is both statistically and economically significant. For instance, regarding the full sample results, an average investment rate of eight per cent - all else equal - reduces liquidity by more than seven per cent 
annually. ${ }^{9}$ Across all specifications estimated in this analysis we find that the coefficients on cash flow and investment are rather insensitive to the partitioning of deviation. We therefore focus solely on the adjustment parameters from here onwards.

For the assessment of directional adjustment asymmetries, we implement equation (6.2) with $d \in\{$ below, above $\}$, with $D^{\text {below(above) }}$ a dummy that takes value 1 if the firm starts a year with a liquidity position below (above) its target. This produces conditional adjustment speeds $\gamma_{\text {below }}$ and $\gamma_{\text {above }}$, where dynamic stability requires that both are negative. Asymmetric target adjustment that relates to the sign of the deviation is empirically reflected by $\gamma_{\text {below }} \neq \gamma_{\text {above }}$. Columns (2), (4), and (6) of table 6.2 present the results. First of all, the estimation results show that the requirements for dynamic stability are met: there is significant target adjustment regardless of whether the liquidity position is initially below or above the target. Second, we observe from the conditional adjustment parameters that adjustment from above or below the target seems to occur at more or less equal speeds. For manufacturing firms as well as for all firms together, we observe slightly faster adjustment from below the target than from above. These results therefore corroborate the suggestive evidence provided by De Haan (1997) and De Haan et al. (1994) of faster liquidity adjustment from below the target. At the same time, however, the point estimates in column (6) suggest faster adjustment from above - if anything - for services firms.

The restriction that $\gamma_{\text {below }}=\gamma_{\text {above }}$ is tested formally in panel $\mathrm{B}$ of the table. The concomitant test statistic for target adjustment unconditional on the sign of the deviation ('Symmetric adjustment') is not significant at conventional levels of confidence. The strongest case against symmetric adjustment can be made for all firms together. Even here, though, the symmetric adjustment test statistic still has a p-value of 17 percent. Hence, symmetric adjustment is hard to reject. The finding of directional symmetry in corporate liquidity adjustment does not readily support the theoretical constellation of marginal costs and benefits of liquidity holdings as outlined in Opler et al. (1999) and figure 6.2 above. In particular, on the basis of figure 6.2 we would expect that the incentives to make adjustments from below the target are stronger than the incentives to make adjustments from above. However, we also observe from the figure that the difference in upward and downward target adjustment incentives may be minor for relatively small deviations. This difference increases rapidly when the deviations becomes larger. Directional asymmetries may then

9 As was discussed in the previous chapter, the absolute impact of these variables on investment is considerably lower. Also refer to the previous chapter for a more elaborate specification of corporate liquidity dynamics and discussion of the results. 


\section{Table 6.2}

(A)symmetries in sign

\begin{tabular}{|c|c|c|c|c|c|c|}
\hline \multicolumn{7}{|c|}{ PANEL A ESTIMATION RESULTS } \\
\hline \multirow[t]{2}{*}{ Independent variables' } & \multicolumn{2}{|c|}{ All } & \multicolumn{2}{|c|}{ Man } & \multicolumn{2}{|c|}{ Ser } \\
\hline & (1) & (2) & (3) & (4) & (5) & (6) \\
\hline \multirow{3}{*}{$\begin{array}{l}\text { Deviation }_{t-1} \times D^{\text {oethov }} \\
\text { Deviation } \\
\text { Deviation }_{t-1} \times D^{\text {atbove }}\end{array}$} & \multirow{3}{*}{$\begin{array}{l}-0.824 \\
(0.059)\end{array}$} & $\begin{array}{l}-0.892 \\
(0.062)\end{array}$ & \multirow{3}{*}{$\begin{array}{l}-0.849 \\
(0.067)\end{array}$} & $\begin{array}{l}-0.941 \\
(0.073)\end{array}$ & & $\begin{array}{l}-0.874 \\
(0.073)\end{array}$ \\
\hline & & & & & $\begin{array}{l}-0.875 \\
(0.090)\end{array}$ & \\
\hline & & $\begin{array}{l}-0.794 \\
(0.064)\end{array}$ & & $\begin{array}{l}-0.825 \\
(0.094)\end{array}$ & & $\begin{array}{l}-0.909 \\
(0.085)\end{array}$ \\
\hline Cash flow & $\begin{array}{c}0.335 \\
(0.113)\end{array}$ & $\begin{array}{c}0.370 \\
(0.107)\end{array}$ & $\begin{array}{c}0.557 \\
(0.186)\end{array}$ & $\begin{array}{c}0.470 \\
(0.180)\end{array}$ & $\begin{array}{c}0.304 \\
(0.169)\end{array}$ & $\begin{array}{l}0.403 \\
(0.153)\end{array}$ \\
\hline \multirow[t]{2}{*}{ Investment, } & -0.912 & -1.315 & -1.770 & -2.240 & -0.454 & -0.459 \\
\hline & $(0.186)$ & $(0.354)$ & $(0.329)$ & $(0.731)$ & $(0.229)$ & $(0.355)$ \\
\hline \multicolumn{7}{|c|}{ PANEL B SUMMARY AND TEST STATISTICS ${ }^{2}$} \\
\hline \multirow{2}{*}{$\begin{array}{l}\text { Firms } \\
\text { Observations }\end{array}$} & 473 & 473 & 197 & 197 & 182 & 182 \\
\hline & 4257 & 4257 & 1773 & 1773 & 1638 & 1638 \\
\hline Joint significance & $\begin{array}{l}\chi^{2}(3)= \\
230.76^{* *}\end{array}$ & $\begin{array}{l}\chi^{2}(4)= \\
310.81^{* * 1}\end{array}$ & $\begin{array}{l}\chi^{2}(3)= \\
230.63^{* *}\end{array}$ & $\begin{array}{l}\chi^{2}(4)= \\
326.64\end{array}$ & $\begin{array}{l}\chi^{2}(3)= \\
94.85^{* * *}\end{array}$ & $\begin{array}{l}\chi^{2}(4)= \\
181.77^{* *}\end{array}$ \\
\hline \multirow[t]{2}{*}{ Sargan } & $x^{2}(16)$ & $x^{2}(24)$ & $\chi^{2}(16)$ & $\chi^{2}(24)$ & $\chi^{2}(16)$ & $\chi^{2}(24)$ \\
\hline & $=23.77$ & $=27.78$ & $=15.32$ & $=23.54$ & $=21.94$ & $=29.99$ \\
\hline SOSC & 1.33 & 1.44 & 1.21 & 1.30 & 0.07 & 0.07 \\
\hline Symmetric adjustment & \multicolumn{2}{|c|}{$\chi^{2}(1)=1.86$} & \multicolumn{2}{|c|}{$\chi^{2}(1)=0.96$} & \multicolumn{2}{|c|}{$\chi^{2}(1)=0.16$} \\
\hline
\end{tabular}

Notes: Random effects estimates of $\Delta$ Liquidity, where Liquidity is defined as before. Standard errors are robust to heteroskedasticity (cf. White, 1982) and reported in parentheses. "All" indicales that the full sample of firms was used in the estimation, "Man" ("Ser") indicates that only manufacturing (services) tirms are used.

1 Deviation $\mathrm{r}_{\mathrm{r} \cdot \mathrm{I}}$ is the deviation from the specific target (defined as before in section 5.4) using the estimates reported in table 6.1. $D^{\text {bedsw }}\left(D^{\text {athose }}\right)$ is a dummy that takes value 1 when Deviation $n_{t-j}$ is negative (positive) and 0 otherwise. All other variables are defined as before. Investment is treated as a potentially endogenous variable and is instrumented with its own level lagged one period. Deviationt, Deviation $_{t-1} \times D^{\text {athive }}$ and Deviation $n_{t-1} \times D^{\text {beiow }}$ are instrumented with one lag of their levels.

2 Joint significance for all variables in the model is tested with a Wald test. Sargan refers to the Sargan test for overidentifying restrictions and is also heteroskedasticityconsistent (cf. Arellano and Bond, 1991). SOSC test for second order autocorrelation and is based on estimates of the residuais in first differences (cf. Arellano and Bond, 1998). 'Symmetric adjustment' tests the restriction $\gamma_{\text {teforw }}=\gamma_{\text {atove }}$. Significance at the 5 and 1 percent error level is indicated by" and ", respectively. 
increase with the size of the deviations. Therefore, in the analysis of target adjustment for particularly large deviations to which we turn next, we will once again test for directional asymmetries.

\subsection{Does size matter?}

\subsubsection{A closer inspection of targets and deviations}

Due to the specific definition of liquidity, the analysis of liquidity adjustment dependent on the size of the deviation first requires a closer look at the distributional properties and interpretation of liquidity targets and deviations. The distributions of corporate liquidity holdings, targeted liquidity holdings, and target deviations are shown in figure 6.3. Figure $6.3 \mathrm{~A}$ displays the distribution of liquidity, defined as the logarithm of the ratio of liquid assets to net assets. Figure $6.3 \mathrm{~B}$, by contrast, shows the distribution of liquid assets as a percentage of net assets, the exponent of liquidity. Comparing the two, it is clear that the distribution of percentage liquidity ratios is asymmetric; there is a concentration of observations (roughly fifty percent of the total) with liquidity ratios in between zero and five percent, whereas the remaining observations are smeared out over the long right tail. Of course, this relates to the fact that the liquidity ratio is censored at zero. Liquidity, by contrast, is an uncensored variable. This is, in fact, an important motivation for its use as the dependent variable in our empirical analysis. Liquidity appears more symmetrically distributed, although it has a slightly negative skew. Similarly, the distributions of targeted liquidity and targeted liquidity ratios, respectively, are displayed in figures $6.3 \mathrm{C}$ and $6.3 \mathrm{D}$. The distributional properties reflect those mentioned for figures $6.3 \mathrm{~A}$ and $6.3 \mathrm{~B}$; the distribution of targeted liquidity ratios has a long right tail, whereas the distribution of targeted liquidity looks considerably more symmetric.

The resulting distributions of target deviations are shown in figures $6.3 \mathrm{E}$ and $6.3 \mathrm{~F}$. In the former, the target deviation is measured as the difference between liquidity and targeted liquidity. Despite a slightly negative skew, this distribution appears quite symmetric. Approximate symmetry implies that a surplus of liquidity of 1 (i.e. $\hat{\varepsilon}_{i t}^{s}=y_{i t}-\hat{y}_{i t}^{s}=1$, with $\hat{y}_{i t}^{s}$ defined in equation (6.1) above) or more relative to targeted liquidity is about as typical as a shortfall of 1 or more. The derived suggestion is that positive and negative deviations of similar magnitude incite roughly equal adjustment efforts. We must bear in mind, however, that this surplus and shortfall of 1 are not deviations of equal magnitude when translated into a percentage target deviation: the former captures liquidity holdings roughly 170 percent above target $\left(e^{1}-1\right)$, whereas the latter indicates a 65 percent shortfall $\left(e^{-1}-1\right)$. 


\section{Figure 6.3}

The distributions of liquidity holdings, targeted holdings, and deviations

(A) Liquidity: $y$

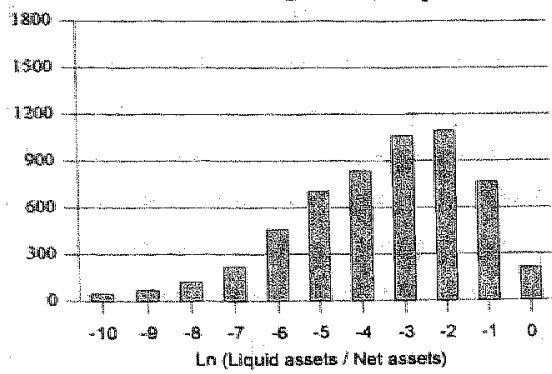

mean $=-3.48(0.03) \quad$ variance $=4.57$ median $=-3.17$ skewness $=-0.70(0.03)$

(C) Target liquidity: $\hat{y}$

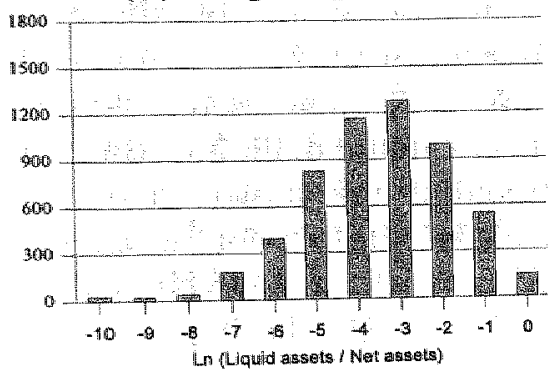

mean $=-3.48(0.02) \quad$ variance $=3.12$ median $=-3.17$ skewness $=-0.49(0.03)$

(E) Target deviation I: $\hat{\varepsilon}=y-\hat{y}$

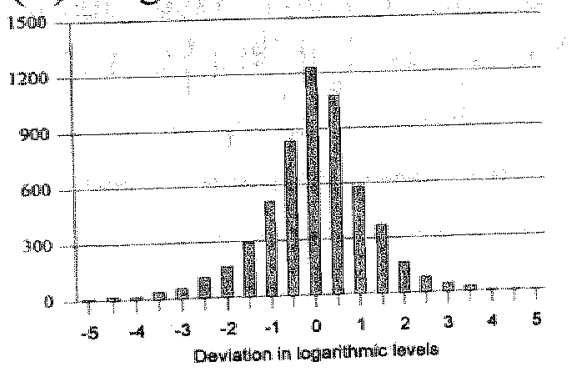

mean $=0.00(0.02)$ median $=0.07 \quad$ skewness $=-0.44(0.03)$
(B) Liquidity ratio: $e^{y}$

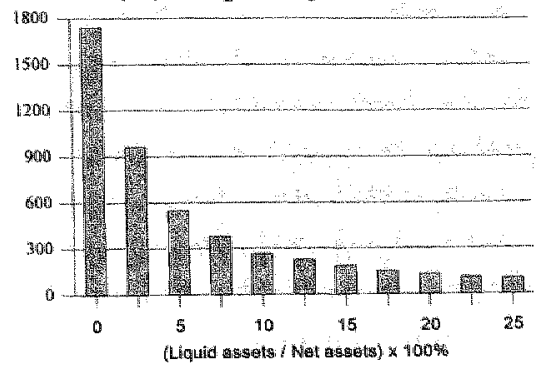

mean $=13.92(0.38) \quad$ variance $=799.11$ median $=4.18 \quad$ skewnéss $=5.53(0.03)$

(D) Target liquidity ratio: $e^{y}$

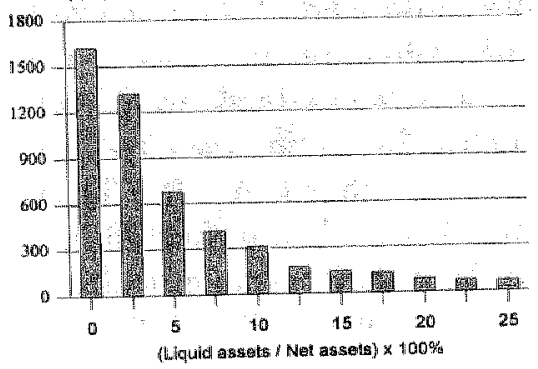

mean $=10.78(0.29) \quad$ variance $=490.60$ median $=3.43 \quad$ skewness $=5.14(0.03)$

(F) Target deviation II: $e^{e}$

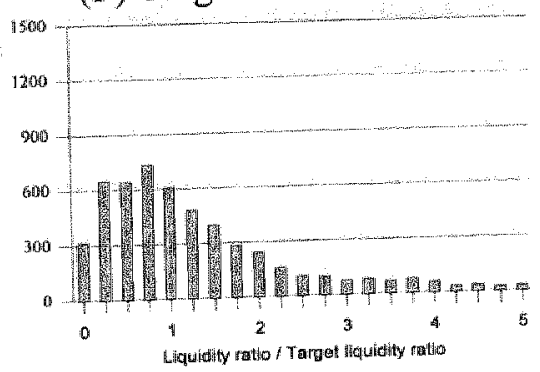

mean $=1.60(0.02) \quad$ variance $=2.51$ median $=1.00 \quad$ sikewness $=1.60(0.03)$

Note: Standard errors are in parentheses. 
The suggestion derived from the observation that adjustment efforts are equal in these two instances can hardly be that target adjustment is unrelated to the sign of the initial deviation. Specifically, for the remainder of the analysis, we consider liquidity adjustment unrelated to the sign of the deviation when liquidity holdings of, say 50 percent above target incite the same relative adjustment effort as liquidity holdings of 50 percent below target. In terms of figure 6.3F, where the target deviation is defined as the ratio of liquid asset holdings to targeted liquidity holdings, this implies that we want to compare liquidity holdings equally far to the right and left of $1 .^{10}$ Thus defined, the figure shows that the distribution of deviations has a significant positive skew, which results in an average liquidity ratio relative to the targeted ratio of 1.60 -i.e. 60 percent above target - although the median firm is exactly on target. The long right tail - deceptively disguised in figure $6.3 \mathrm{E}$ through the logarithmic transformation - actually suggests that adjustment efforts may be smaller in case of liquidity abundance than in case of a liquidity shortage relative to target.

Similarly, we consider liquidity adjustment to be unrelated to the size of the deviation when a large deviation of, say 50 percent or more from the target in either direction incites the same relative adjustment effort as a moderate deviation of less than 50 percent from the target. As before, this implies symmetric thresholds for large deviations in terms of figure $6.3 \mathrm{~F}$, but results in asymmetric thresholds in figure 6.3E. Partitioning the target deviations symmetrically when measured in logarithmic levels is therefore not the same as partitioning them symmetrically when measured in percentage deviations and may lead to misleading interpretations when used to assess the impact of the size of the deviation on target adjustment.

\subsubsection{Asymmetries in size}

For the analysis of adjustment asymmetries relating to the size of the deviation we implement equation (6.2) with $d \in\{$ low, medium, high $\}$. Here dummy variables $D^{\text {low }}$ and $D^{\text {high }}$ take value 1 , respectively, when the firm's target deviation at the start of the year exceeds a specific threshold in the left or right tail of the deviations distribution. $D^{\text {medium }}$ is a dummy that is 1 in those instances where the deviation does not exceed the upper or lower threshold.

10. In contrast, the example of liquidity holdings more than 50 percent above (below) the target translates into target deviations of $0.41(-0.69)$ or higher (lower) in figure $6.3 \mathrm{E}$. Thus, we have already moved farther into the left than into the right tail of the distribution. Note that the distinction between the measurement of the deviation in figures $6.3 \mathrm{E}$ and $6.3 \mathrm{~F}$ is trivial when positive and negative deviations only are separated. Then, any negative (positive) deviation in figure 6.3E corresponds to a measure of deviation less (more) than 1 in figure $6.3 \mathrm{~F}$. 
$\gamma_{\text {low }}, \gamma_{\text {mediam }}$, and $\gamma_{\text {high }}$ therefore capture the adjustment speed conditional on the size of target deviation. Dynamic stability requires that at least $\gamma_{\text {low }}$ and $\gamma_{\text {high }}$ are both negative. Furthermore, insofar as adjustment incentives increase in the size of the target deviation, we expect both $\gamma_{\text {low }}$ and $\gamma_{\text {high }}$ to exceed $\gamma_{\text {medium }}$ in absolute terms.

Panel A of table 6.3 displays the estimation results of target adjustment conditioned by the size of the start-of-year deviation. The threshold values for $D^{\text {low }}$ and $D^{\text {high }}$ are defined as percentage deviations of liquidity from targeted levels. ${ }^{11}$ We vary these thresholds as we consider increasingly larger deviations and indicate in the column headings the specific set of threshold values used. As we move farther away from the corporate liquidity target, we obtain the following results.

The first result pertains to the requirements for dynamic stability of the error correction mechanism. These requirements $-\gamma_{\text {low }}<0$ and $\gamma_{\text {high }}<0-$ are always satisfied. Individually, these parameters are always negative and statistically discernible from 0 at the 99 percent level of confidence. Jointly, the restriction that $\gamma_{\text {low }}=\gamma_{\text {high }}=0$ is evaluated in panel B of the table with the test statistic 'zero tail adjustment'. $\gamma_{\text {low }}$ and $\gamma_{\text {high }}$ are jointly significantly different from zero in all instances. We have conducted a finer range of thresholds than that reported in table 6.3. Specifically, threshold values $f^{\text {low }}=-$ $5 \%$; high $=+5 \%\}$ were widened with 5 percent per step up to $\left\{^{\text {low }}=-95 \%\right.$; high $=$ $+95 \%$. The above findings also apply to the sets of threshold values that are not reported in the table.

The second result pertains to the observed adjustment for the group with intermediate target deviations, i.e. $\gamma_{\text {medium }}$. Here we note that it takes quite large deviations away from the target to observe statistically significant adjustment. For liquidity holdings as far away as 70 percent from the target in either direction, no meaningful adjustment is observed as $\gamma_{\text {medium }}$ lacks significance in columns (1) to (5). ${ }^{12}$ Only for liquidity positions that stray away from the target to up to 75 percent in either direction do we start to see efforts to return to the target; in column (6) $\gamma_{\text {medium }}$ is significantly different from 0 at the 90 percent

$11 \quad D^{\text {kow }}=-25 \%$ and $D^{\text {high }}=25 \%$ sorts out all deviations smaller than 0.75 or larger than 1.25 , respectively, in terms of figure $6.3 \mathrm{~F} . D^{\prime o w}=-50 \%$ and $D^{\text {high }}=50 \%$ those smaller than 0.50 and larger than 1.50 . In contrast, in terms of figure $6.3 \mathrm{E}$ deviations smaller than 0.29 and larger than 0.22 are sorted out when $D^{\text {bow }}=-25 \%$ and $D^{\text {high }}=25 \%$ and those smaller than -0.69 and larger than 0.41 when $D^{\prime \prime w}=-50 \%$ and $D^{\text {high }}=50 \%$. Hence applying symmetric criteria to the target deviations means that we move faster into the left than into the right tail of the deviation distribution (figure 6.3E). 
Table 6.3

(A)symmetries in size: all firms

\begin{tabular}{|c|c|c|c|c|}
\hline \multicolumn{5}{|c|}{ PANELA ESTMATION RESULTS } \\
\hline $\begin{array}{l}\text { Independent } \\
\text { variables }\end{array}$ & $\begin{array}{c}\text { (1) } \\
=-5 \% \\
\text { lowigh }=-5 \%\end{array}$ & $\begin{array}{c}(2) \\
\text { now }=-10 \% \\
=+10 \%\end{array}$ & $\begin{array}{c}\text { (3) } \\
\text { low }=-25 \% \\
\text { high }=+25 \%\end{array}$ & $\begin{array}{c}\text { (4) } \\
\text { how }=-55 \% \\
=+55 \%\end{array}$ \\
\hline \multirow[t]{2}{*}{ Deviation $_{\gamma=1} \times D^{\text {bax }}$} & -0.902 & -0.868 & -0.886 & -0.974 \\
\hline & $(0.063)$ & $(0.060)$ & $(0.064)$ & $(0.076)$ \\
\hline \multirow[t]{2}{*}{ Deviation $_{1-1} \times D^{\text {methom }}$} & -26.247 & 0.013 & -2.895 & 0.180 \\
\hline & $(29.623)$ & $(6.884)$ & $(2.619)$ & $(0.471)$ \\
\hline \multirow[t]{2}{*}{ Deviation ${ }_{t-1} \times D^{\text {hight }}$} & -0.787 & -0.780 & -0.777 & -0.843 \\
\hline & $(0.064)$ & $(0.063)$ & $(0.069)$ & $(0.072)$ \\
\hline \multirow[t]{2}{*}{ Cash flow, } & 0.362 & 0.358 & 0.374 & 0.336 \\
\hline & $(0.108)$ & $(0.106)$ & $(0.112)$ & $(0.108)$ \\
\hline \multirow[t]{2}{*}{ Investment, } & -1.383 & -1.245 & -1.448 & -0.832 \\
\hline & $(0.382)$ & $(0.366)$ & $(0.446)$ & $(0.383)$ \\
\hline
\end{tabular}

Panel B Summary STATISTICS AND Test StatistiCs ${ }^{2}$

\begin{tabular}{|l|r|c|r|r|}
\hline \# Firms & 473 & 473 & 473 & 473 \\
\# Observations & 4257 & 4257 & 4257 & 4257 \\
\hline Joint significance & $\chi^{2}(5)=$ & $\chi^{2}(5)=$ & $\chi^{2}(5)=$ & $\chi^{2}(5)=$ \\
Sargan & $300.20^{* *}$ & $314.80^{* *}$ & $301.67^{* *}$ & $287.63^{* *}$ \\
& $\chi^{2}(32)=$ & $\chi^{2}(32)=$ & $\chi^{2}(32)=$ & $\chi^{2}(32)=$ \\
SOSC & 33.82 & 37.97 & 41.43 & 43.11 \\
Zero tail adjustment & 1.29 & 1.28 & 1.39 & 1.51 \\
& $\chi^{2}(2)=$ & $\chi^{2}(2)=$ & $\chi^{2}(2)=$ & $\chi^{2}(2)=$ \\
Zero incremental tail & $268.21^{* *}$ & $274.83^{* *}$ & $237.32^{* *}$ & $206.92^{* *}$ \\
adjustment & $\chi^{2}(2)=$ & $\chi^{2}(2)=$ & $\chi^{2}(2)=$ & $\chi^{2}(2)=$ \\
Symmetric tail & 2.78 & 1.65 & 2.38 & $6.54^{*}$ \\
adjustment & $\chi^{2}(1)=$ & $\chi^{2}(1)=$ & $\chi^{2}(1)=$ & $\chi^{2}(1)=$ \\
\hline
\end{tabular}

Notes: Random effects estimates of $\Delta$ Liquidity, with Liquidity defined as before. Standard $1 D^{\text {low }}\left(D^{\text {hight }}\right)$ is a dummy that takes value 1 when Liquidity $y_{t-1}$ deviates from the target by when the deviation is in between the upper $\left({ }^{\text {dight }}\right)$ and lower $\left({ }^{\text {tow }}\right)$ threshold values. target. All other variables are defined as before. Investment is treated as a potentially

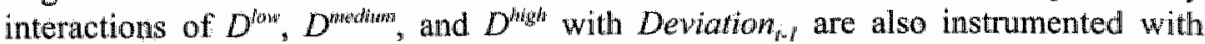

2 Joint significance of all variables in the model is tested with a Wald test. Sargan consistent (cf. Arellano and Bond, 1991). SOSC tests for second order Bond, 1998). 'Zero tail adjustment' tests the restriction $\gamma_{\text {tow }}=\gamma_{\text {hight }}=0$, whereas adjustment' tests the restriction $\gamma_{\text {tew }}=\gamma_{\text {hight }}$. Significance at the 5 and 1 percent error 


\begin{tabular}{|c|c|c|c|c|}
\hline $\begin{array}{c}(5) \\
\text { lowi }=-70 \% \\
\text { high }=+70 \%\end{array}$ & $\begin{array}{c}(6) \\
\text { low }=-75 \% \\
\text { high }=+75 \%\end{array}$ & $\begin{array}{c}(7) \\
\text { tow }=-80 \% \\
\text { high }=+80 \%\end{array}$ & $\begin{array}{c}(8) \\
\text { how }=-85 \% \\
\text { hughi }=+85 \%\end{array}$ & $\begin{array}{l}\text { Independent } \\
\text { variables }\end{array}$ \\
\hline $\begin{array}{c}-1.018 \\
(0.082) \\
-0.325 \\
(0.222) \\
-0.833 \\
(0.070) \\
0.360 \\
(0.110) \\
-0.907 \\
(0.340) \\
\end{array}$ & $\begin{array}{c}-1.030 \\
(0.085) \\
-0.289 \\
(0.175) \\
-0.863 \\
(0.070) \\
0.350 \\
(0.107) \\
-0.626 \\
(0.340) \\
\end{array}$ & $\begin{array}{c}-1.114 \\
(0.100) \\
-0.339 \\
(0.159) \\
-0.855 \\
(0.072) \\
0.342 \\
(0.105) \\
-0.628 \\
(0.343) \\
\end{array}$ & $\begin{array}{c}-1.196 \\
(0.108) \\
-0.461 \\
(0.129) \\
-0.877 \\
(0.071) \\
0.338 \\
(0.106) \\
-0.617 \\
(0.337) \\
\end{array}$ & 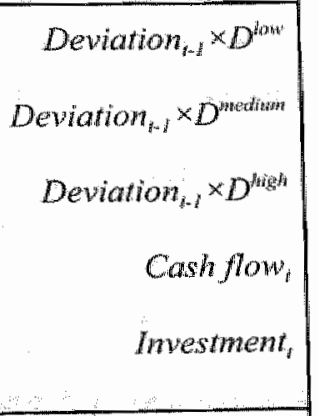 \\
\hline $\begin{array}{r}473 \\
4257 \\
\end{array}$ & $\begin{array}{r}473 \\
4257 \\
\end{array}$ & $\begin{array}{r}473 \\
4257 \\
\end{array}$ & $\begin{array}{r}473 \\
4257 \\
\end{array}$ & $\begin{array}{r}\text { \# Firms } \\
\text { \# Observations }\end{array}$ \\
\hline $\begin{array}{c}\chi^{2}(5)= \\
304.46^{\circ} \\
\chi^{2}(32)= \\
39.35 \\
1.42 \\
\end{array}$ & $\begin{array}{c}\chi^{2}(5)= \\
310.81^{* * *} \\
\chi^{2}(32)= \\
37.48 \\
1.35 \\
\end{array}$ & $\begin{array}{c}\chi^{2}(5)= \\
292.51^{* * *} \\
\chi^{2}(32)= \\
33.13 \\
1.56 \\
\end{array}$ & $\begin{array}{c}\chi^{2}(5)= \\
328.10^{* *} \\
\chi^{2}(32)= \\
35.25 \\
1.53 \\
\end{array}$ & $\begin{array}{r}\text { Joint significance } \\
\text { Sargan } \\
\text { SOSC }\end{array}$ \\
\hline $\begin{array}{c}\chi^{2}(2)= \\
213.83^{* *} \\
\chi^{2}(2)= \\
7.69^{*} \\
\chi^{2}(1)= \\
4.63^{\circ}\end{array}$ & $\begin{array}{c}\chi^{2}(2)= \\
208.89^{4 *} \\
\chi^{2}(2)= \\
10.98^{* * *} \\
x^{2}(1)= \\
3.83^{*}\end{array}$ & $\begin{array}{c}\chi^{2}(2)= \\
186.55^{* *} \\
\chi^{2}(2)= \\
12.26^{* 4} \\
\chi^{2}(1)= \\
7.20^{* *}\end{array}$ & $\begin{array}{c}\chi^{2}(2)= \\
197.01^{* *} \\
\chi^{2}(2)= \\
13.57^{* *} \\
\chi^{2}(1)= \\
9.54^{* *}\end{array}$ & $\begin{array}{r}\text { Zero tail adjustment } \\
\text { Zero incremental tail } \\
\text { adjustment } \\
\text { Symmetric tail } \\
\text { adjustment }\end{array}$ \\
\hline
\end{tabular}

errors are robust to heteroskedasticity (cf. White, 1982) and reported in parentheses.

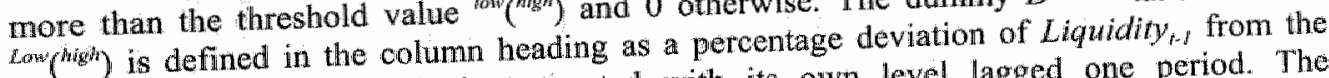
endogenous variable and is instrumented with its own level lagged one period. The one lag of their own level.

refers to the Sargan test for overidentifying restrictions and is also heteroskedasticityautocorrelation and is based on estimates of the residuals in first differences (cf. Arellano and

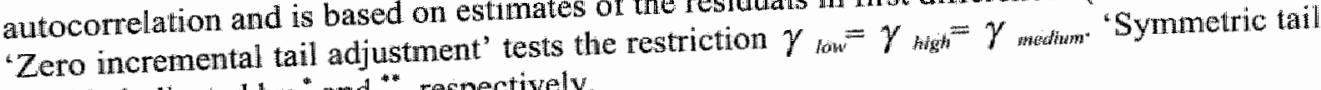
level is indicated by "and ", respectively. 
level of confidence. For wider ranges of medium target deviations, adjustment for the group with intermediate deviations is statistically significant at the 95 percent confidence level or higher.

In panel $\mathrm{B}$, furthermore, we explicitly compare the rates of target adjustment for the medium group with the rates of target adjustment farther in the tails. In particular, the test statistic "zero incremental tail adjustment" evaluates the restriction that $\gamma_{\text {low }}=\gamma_{\text {high }}=\gamma_{\text {medium }}$. The rejection of this restriction at the 95 percent level of confidence or higher from column (5) onwards demonstrates the far more rapid adjustment that follows from large positive and negative deviations from the target. While the restriction cannot be rejected in columns (1), (2), and (3), this is solely the result of the large degree of uncertainty surrounding the value of $\gamma_{\text {medium }}$ there.

Put together, the results discussed so far point strongly towards the existence of a broad range of inactivity in the adjustment of corporate liquidity holdings to targeted levels. In fact, corporate liquidity may deviate by some 70 percent from its targeted level before a clear effort is made to return to the target. For larger deviations, however, adjustment is statistically significant as well as economically meaningful: target adjustment for deviations in excess of 70 percent are - all else equal - roughly removed within a single year. ${ }^{13}$ The swiftness of adjustment in these instances indicates the increase in relative importance of liquidity adjustment when liquidity holdings fall particularly far below target or rise particularly far above target.

To the extent that we measure the adjustment speeds of fairly small sets of observations when we move farther away from the target into the tails of the deviations distribution, the changing proportion of manufacturing and services

1) Alternative partitioning schemes also point to the existence of a range of inaction. Specifically, we have also assessed the adjustment parameter per quintile of the deviation distribution (with the first quintile representing the lowest liquidity holdings relative to the (arget). From this exercise we obtained negative parameter estimates for the first, fourth, and fifth quintile, all of which were significant at the five percent level (for the fourth quintile) or better. In addition, the estimated coefficient was highest for the third quintile and monotonically decreased when moving to lower or higher quintiles. This suggests a range of inaction runing from the $20^{\text {th }}$ to the $60^{\text {th }}$ percentile. Similarly, we assessed the adjustment parameter per decile of the deviation distribution (with the first decile representing the lowest liquidity holdings relative to the target). Here we obtained negative parameter estimates for the first till the fourth as well as for the seventh till the tenth decile. These parameter estimates where insignificantly different from zero for the fourth and seventh decile; significant at the ten percent error level for the third decile; significant at the five percent level for the second and eighth decile; and significant at the one percent error level for the first, ninth, and tenth decile. 
firms between thresholds may drive some of our findings. ${ }^{14}$ Target adjustment results conditioned by the size of the target deviation are therefore presented for manufacturing and services firms separately in the appendix to this chapter. The results are summarised as follows. For manufacturing and services firms alike we find a range of inaction that captures liquidity holdings as far away as 70 percent from the target in either direction. Larger deviations incite statistically significant and economically meaningful adjustment efforts. These results confirm the general nature of our findings in table 6.3 above for the full sample of firms.

The results in table 6.3 also shed some light on the effect that the sign of the deviation has on the implied importance of target adjustment. In column (1), we see that convergence towards the target occurs at a rate of 90 percent on average when liquidity holdings fall short of the target by more than 5 percent. For liquidity holdings in excess of the liquidity target by more than 5 percent, this rate of target convergence is slightly lower at 80 percent. Moving farther away from the target in columns (2) through (8), we observe that the rate of target convergence increases both for liquidity holdings farther below the target and for liquidity holdings farther in excess of the target. However, the speed of target adjustment rises more rapidly in the former case. In fact, liquidity positions 85 percent or more below the target incite an overzealous adjustment speed of 120 percent (column (8)). In contrast, a similar position above target associates with an adjustment speed of less than 90 percent. The statistical significance of this difference is assessed in panel $\mathrm{B}$ where we evaluate the restriction that $\gamma_{\text {low }}=\gamma_{\text {high }}$ ('symmetric tail adjustment'). The clear rejection of this restriction at a confidence level of 99 percent underlines the fact that adjustment from far below the target is meaningfully faster than adjustment from far above the target. Thus we also find evidence of asymmetries in liquidity adjustment related to the sign of large deviations. This directional asymmetry first appears (with 90 percent confidence) when we compare the adjustment from liquidity holdings short of the target by 55 percent or more with the adjustment from similar positions above the target (column (4)). The statistical support for this asymmetry increases when we consider liquidity positions farther below and above the target in columns (5) and onwards. These findings favour a constellation of marginal costs and benefits of corporate

14 Note in this regard that we have already seen in the previous chapter as well as in tables 6.1 and 6.2 above that manufacturing and services firms do not differ a lot in the way liquidity targets are formulated or in the speed of adjustment towards these targets. Nevertheless, they may still differ considerably in terms of adjustment asymmetries related to the size of the deviation. 
liquidity holdings as represented in figure 6.2 over the constellation in figure 6.1.

We want to stress the importance of partitioning the error term on the basis of percentage target deviations $\left(e^{\hat{\varepsilon}}\right)$ for the interpretation of the empirical results. In fact, we have also conducted the liquidity adjustment analysis using $\hat{\varepsilon}$, rather than $e^{\varepsilon}$, to partition the error term. For that exercise we implemented equation (6.2) with $d \in\{$ low, medium, high $\}$ where the dummies $D^{\text {low }}$ and $D^{\text {high }}$ take value 1 , respectively, when the firms' $\hat{\varepsilon}_{i t}$ were lower or higher than a specific percentile of the $\hat{\varepsilon}$ distribution. The (unreported) results summarise as follows. Target deviations in between the $20^{\text {th }}$ and $80^{\text {th }}$ percentile of the $\varepsilon$ distribution do not associate with statistically significant adjustment towards the target. This suggests a symmetric range of inaction, in line with the results in table 6.3. The lowest and highest 20 percent of the target deviations do associate with statistically significant target adjustment. However, the speed of adjustment is similar regardless of whether the deviation is among the lowest or the highest 20 percent of the deviations. This suggests that asymmetries related to the sign of large deviations are absent, which contrasts with the results in table 6.3. Both suggestions are misleading, however. Particularly, the $20^{\text {th }}$ and $80^{\text {th }}$ percentiles of the $\hat{\varepsilon}$ distribution are -0.83 and 0.86 , respectively. Evaluated at sample average liquidity of -3.48 (recall table 5.1 ) this implies that liquidity in between -4.31 and -2.62 does not associate with statistically significant adjustment to target. Converting these boundaries back into percentage liquidity ratios, liquidity may vary more or less freely around its average of $3.1 \%$ so long as it does not fall short of $1.3 \%$ or exceed $7.3 \%$. This range of inaction is therefore asymmetric around the average liquidity ratio. Furthermore, it is difficult to reconcile the equality of adjustment speed from a position 0.8 percentage points (or 25 percent) below target and 4.2 percentage points (or 135 percent) above target with absence of adjustment asymmetries related to the sign of large deviations.

Lastly, we should note that the adjustment speeds reported from liquidity positions far away from the target in table 6.3 differ between manufacturing and services firms. Specifically, when compared to table 6.3 we find in the appendix that manufacturing firms typically adjust somewhat swifter from liquidity positions far below and somewhat slower from positions far above the target, resulting in a larger adjustment speed differential. ${ }^{15}$ For services firms the opposite is true. There, adjustment from far above the target is somewhat more rapid, while adjustment from far below is somewhat slower; producing a strong

15 The statistical test on symmetric tail adjustment can be rejected at the 90 percent confidence level in columns (5) through (8) of table A6.1. 
case for symmetric adjustment from positions far away from the target in either direction. Hence target adjustment conditional on the sign of the large deviation is a feature specific to manufacturing firms and likely drives our findings in this regard for all firms together.

\subsection{Summary and conclusions}

Firms formulate target levels for corporate liquidity holdings and make efforts to converge towards these targets even in the short run. The urgence with which target convergence is pursued, however, may vary with the gap between actual and targeted liquidity holdings. When adjustments in liquidity holdings are a quick and relatively costless option, for instance, it may be optimal to have these holdings passively accommodate adjustment in other corporate decision areas like the capital stock or the capital structure. This suggests that the shortrun adjustment of corporate liquidity holdings towards targeted levels has low priority. Our empirical findings regarding short-run adjustment of corporate liquidity to targeted levels partially confirm such conjecture. In particular, we find a range of inactivity in which liquidity holdings can freely vary without inciting any kind of structural adjustment efforts. Such inactivity pertains to liquidity holdings that deviate from the target by up to 70 percent. Within this range corporate liquidity apparently serves its role as shock absorber best; the liquidity ratio is free to vary and follows corporate decisions regarding for instance capital stock or capital structure adjustment. At the very least the inaction implies that the corporate liquidity decision is not a restriction when the firm decides upon such adjustment.

At the same time, however, when the gap between actual and optimal liquidity holdings gets too wide, we find meaningful and statistically significant convergence towards the target. This suggests that large deviations of liquidity from the target increase the urgency of target convergence. Adjustment speeds are high in these instances; convergence towards the target is roughly achieved in a single year. Together these findings imply that target convergence is so important when liquidity is very high or low relative to the target that other corporate decisions are made subject to the liquidity decision. When liquidity holdings fall far short of the target, for instance, a desired increase in the firm's capital stock may be postponed in favour of an increase in liquidity holdings towards the target. The spillover from the corporate liquidity decision towards the investment decision is examined in detail in the next chapter.

In line with related Dutch research on the adjustment of corporate liquidity, we also find that adjustment is faster when liquidity falls far short of the target than when it exceeds the target by the same distance. This supports 
the hypothesis that large shortfalls of liquidity relative to target are more costly. than large surpluses. However, we also find that this result holds for a part of our sample only; for services firms there is no such indication whatsoever.

The main result of our analysis is thus that the corporate liquidity ratio is not automatically the least costly adjustment option among the range of required financial adjustments in each and every year. Though passive accommodation of postponed adjustment in other financial balance items is accepted for a wide range of liquidity holdings, when the liquidity ratio strays sufficiently far away from its targeted level, liquidity adjustment increases in priority relative to the firm"s other adjustment deeisions and quick target convergence results. At the aggregate level, the adjustment of corporate liquidity holdings to shocks is then dependent on the initial distribution of the target deviations across firms and likely nonlinear as a result. 
Appendix: (A)symmetries in size for manufacturing and services firms

\section{Table A6.1}

\section{(A) symmetries in size: manufacturing firms}

\begin{tabular}{|c|c|c|c|c|}
\hline $\begin{array}{l}\text { Independent } \\
\text { variables }\end{array}$ & $\begin{array}{c}(1) \\
\text { low }=-5 \% \\
=+5 \%\end{array}$ & $\begin{array}{c}(2) \\
\text { khw }=-10 \% \\
=+10 \%\end{array}$ & $\begin{array}{c}\text { (3) } \\
\text { hignt }=-25 \% \\
=\end{array}$ & $\begin{aligned} &(4) \\
& \text { low }=-55 \% \\
& \text { high }=+55 \% \\
&\end{aligned}$ \\
\hline 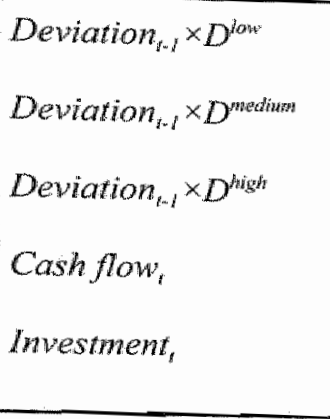 & $\begin{array}{c}-0.982 \\
(0.070) \\
-30.640 \\
(18.643) \\
-0.811 \\
(0.093) \\
0.462 \\
(0.193) \\
-2.638 \\
(0.752) \\
\end{array}$ & $\begin{array}{c}-0.918 \\
(0.070) \\
-8.494 \\
(6.039) \\
-0.806 \\
(0.091) \\
0.485 \\
(0.177) \\
-2.217 \\
(0.696) \\
\end{array}$ & $\begin{array}{l}-0.908 \\
(0.078) \\
-3.254 \\
(3.727) \\
-0.812 \\
(0.096) \\
0.520 \\
(0.194) \\
-2.322 \\
(0.809) \\
\end{array}$ & $\begin{array}{c}-1.037 \\
(0.078) \\
0.101 \\
(0.607) \\
-0.838 \\
(0.101) \\
0.444 \\
(0.181) \\
-2.084 \\
(0.755) \\
\end{array}$ \\
\hline \multicolumn{5}{|c|}{ PANEL B SUMMARY STATISTICS AND TEST STATISTICS ${ }^{2}$} \\
\hline $\begin{array}{l}\text { \#irms } \\
\text { \#Observations }\end{array}$ & $\begin{array}{r}197 \\
1773 \\
\end{array}$ & $\begin{array}{r}197 \\
1773 \\
\end{array}$ & $\begin{array}{r}197 \\
1773 \\
\end{array}$ & $\begin{array}{r}197 \\
1773 \\
\end{array}$ \\
\hline $\begin{array}{l}\text { Joint significance } \\
\text { Sargan } \\
\text { SOSC }\end{array}$ & $\begin{array}{c}\chi^{2}(5)= \\
341.69^{* *} \\
\chi^{2}(32)= \\
27.11 \\
1.19\end{array}$ & $\begin{array}{c}x^{2}(5)= \\
336.26^{* *} \\
x^{2}(32)= \\
29.49 \\
1.23\end{array}$ & $\begin{array}{c}x^{2}(5)= \\
316.14^{* *} \\
\chi^{2}(32)= \\
28.48 \\
1.19\end{array}$ & $\begin{array}{c}\chi^{2}(5)= \\
321.35^{\circ *} \\
\chi^{2}(32)= \\
32.55 \\
1.35\end{array}$ \\
\hline $\begin{array}{l}\text { Zero tail adjustment } \\
\text { Zero incremental tail } \\
\text { adjustment } \\
\text { Symmetric tail } \\
\text { adjustment }\end{array}$ & $\begin{array}{c}\chi^{2}(2)= \\
278.55^{* *} \\
x^{2}(2)= \\
4.06 \\
\chi^{2}(1)= \\
2.11\end{array}$ & $\begin{array}{c}\chi^{2}(2)= \\
254.30^{\circ} \\
\chi^{2}(2)= \\
2.33 \\
\chi^{2}(1)= \\
0.94\end{array}$ & $\begin{array}{c}\chi^{2}(2)= \\
199.62^{* *} \\
\chi^{2}(2)= \\
0.98 \\
\chi^{2}(1)= \\
0.64\end{array}$ & $\begin{array}{c}\chi^{2}(2)= \\
219.24^{* *} \\
\chi^{2}(2)= \\
5.45 \\
\chi^{2}(1)= \\
2.81\end{array}$ \\
\hline
\end{tabular}

Notes: Random effects estimates of $\Delta$ Liquidity s with Liquidity defined as before. Standard errors are robust to heteroskedasticity (cf. White, 1982) and reported in parentheses.

1 All variables are defined as before. Investment is treated as a potentially endogenous variable and is instrumented with its own level lagged one period. The interactions of $D^{\text {imw }}, D^{\text {anediws }}$, and $D^{\text {high }}$ with Deviation, are also instrumented with one lag of their own level.

2 For notes on the test statistics see table 6.3. Significance at the 5 and 1 percent error level is indicated by "and "* respectively. 
Table A6.1

(A)symmetries in size: manufacturing firms (continued)

\begin{tabular}{|c|c|c|c|c|}
\hline \multicolumn{5}{|c|}{ PANEL A ESTIMATION RESULTS } \\
\hline $\begin{array}{l}\text { Independent } \\
\text { variables }\end{array}$ & $\begin{array}{c}(5) \\
=-70 \% \\
=+70 \%\end{array}$ & $\begin{array}{c}(6) \\
=-75 \% \\
=+75 \%\end{array}$ & $\begin{array}{c}(7) \\
=-80 \% \\
\text { high }=+80 \%\end{array}$ & $\begin{array}{c}(8) \\
=-85 \% \\
=+85 \%\end{array}$ \\
\hline 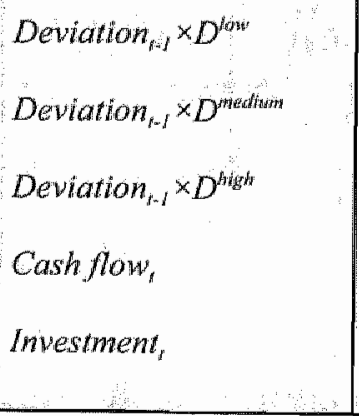 & $\begin{array}{c}-1.061 \\
(0.084) \\
-0.447 \\
(0.282) \\
-0.822 \\
(0.096) \\
0.516 \\
(0.179) \\
-2.043 \\
(0.688) \\
\end{array}$ & $\begin{array}{l}-1.068 \\
(0.086) \\
-0.395 \\
(0.224) \\
-0.835 \\
(0.098) \\
0.519 \\
(0.171) \\
-1.878 \\
(0.678)\end{array}$ & $\begin{array}{c}-1.078 \\
(0.087) \\
-0.579 \\
(0.183) \\
-0.854 \\
(0.096) \\
0.499 \\
(0.165) \\
-1.776 \\
(0.661)\end{array}$ & $\begin{array}{c}-1.221 \\
(0.103) \\
-0.383 \\
(0.172) \\
-0.970 \\
(0.107) \\
0.406 \\
(0.165) \\
-0.869 \\
(0.739)\end{array}$ \\
\hline \multicolumn{5}{|c|}{ PANEL B SUMMARY STATISTICS AND TEST STATISTICS 2} \\
\hline $\begin{array}{l}\text { \# Firms } \\
\text { \# Observations }\end{array}$ & $\begin{array}{r}197 \\
1773 \\
\end{array}$ & $\begin{array}{r}197 \\
1773 \\
\end{array}$ & $\begin{array}{r}197 \\
1773 \\
\end{array}$ & $\begin{array}{r}197 \\
1773 \\
\end{array}$ \\
\hline $\begin{array}{l}\text { Joint significance } \\
\text { Sargan } \\
\text { SOSC } \\
\end{array}$ & $\begin{array}{c}\chi^{2}(5)= \\
301.26^{* *} \\
\chi^{2}(32)= \\
32.41 \\
1.22 \\
\end{array}$ & $\begin{array}{c}\chi^{2}(5)= \\
302.02^{* * *} \\
\chi^{2}(32)= \\
33.55 \\
1.06 \\
\end{array}$ & $\begin{array}{c}\chi^{2}(5)= \\
327.56^{4 *} \\
\chi^{2}(32)= \\
33.97 \\
1.17\end{array}$ & $\begin{array}{c}\chi^{2}(5)= \\
309.61^{* *} \\
\chi^{2}(32)= \\
28.15 \\
1.19\end{array}$ \\
\hline $\begin{array}{l}\text { Zero tail adjustment } \\
\text { Zero incremental tail } \\
\text { adjustment } \\
\text { Symmetric tail } \\
\text { adjustment }\end{array}$ & $\begin{array}{c}\chi^{2}(2)= \\
228.59^{* *} \\
\chi^{2}(2)= \\
5.83 \\
x^{2}(1)= \\
3.62 \\
\end{array}$ & $\begin{array}{c}x^{2}(2)= \\
207.01^{* *} \\
x^{2}(2)= \\
8.07^{*} \\
x^{2}(1)= \\
3.58\end{array}$ & $\begin{array}{c}\chi^{2}(2)= \\
202.83^{* *} \\
\chi^{2}(2)= \\
6.56 \\
\chi^{2}(1)= \\
3.56\end{array}$ & $\begin{array}{c}\chi^{2}(2)= \\
184.08^{* *} \\
\chi^{2}(2)= \\
13.67^{* 4} \\
\chi^{2}(1)= \\
3.62\end{array}$ \\
\hline
\end{tabular}

Notes: Random effects estimates of $\Delta$ Liquidity, with Liquidity defined as before. Standard errors are robust to heteroskedasticity (cf. White, 1982) and reported in parentheses.

1 All variables are defined as before. Investment is treated as a potentially endogenous variable and is instrumented with its own level lagged one period. The interactions of $D^{\text {tow }}, D^{\text {meditim }}$, and $D^{\text {tigh }}$ with Deviation $t_{t, l}$ are also instrumented with one lag of their own level.

2 For notes on the test statistics see table 6.3. Significance at the 5 and 1 percent error level is indicated by ${ }^{*}$ and ${ }^{* *}$, respectively. 


\section{Table A6.2}

(A)symmetries in size: services firms

\begin{tabular}{|c|c|c|c|c|}
\hline \multicolumn{5}{|c|}{ PANEL A ESTIMATLON RESULTS } \\
\hline $\begin{array}{l}\text { Independent } \\
\text { variables }\end{array}$ & $\begin{array}{c}\text { (1) } \\
=-5 \% \\
\text { hight }=+5 \%\end{array}$ & $\begin{array}{c}\text { (2) } \\
\text { low }=-10 \% \\
\text { high }=+10 \%\end{array}$ & $\begin{array}{c}(3) \\
\text { low }=-25 \% \\
\text { high }=+25 \%\end{array}$ & $\begin{array}{c}(4) \\
=-55 \% \\
=+55 \%\end{array}$ \\
\hline $\begin{array}{l}\text { Deviation }_{t-4} \times D^{\text {low }} \\
\text { Deviation }_{t-1} \times D^{\text {meditum }} \\
\text { Deviation }_{t-1} \times D^{\text {hight }} \\
\text { Cash flow } \\
\text { Imestment }\end{array}$ & $\begin{array}{c}-0.848 \\
(0.066) \\
9.263 \\
(20.167) \\
-0.903 \\
(0.084) \\
0.367 \\
(0.148) \\
-0.268 \\
(0.349) \\
\end{array}$ & $\begin{array}{c}-0.802 \\
(0.067) \\
5.444 \\
(7.842) \\
-0.827 \\
(0.083) \\
0.315 \\
(0.152) \\
-0.402 \\
(0.365) \\
\end{array}$ & $\begin{array}{c}-0.884 \\
(0.070) \\
-0.436 \\
(2.231) \\
-0.908 \\
(0.083) \\
0.411 \\
(0.152) \\
-0.414 \\
(0.460) \\
\end{array}$ & $\begin{array}{c}-0.882 \\
(0.080) \\
-0.239 \\
(0.433) \\
-0.856 \\
(0.086) \\
0.396 \\
(0.146) \\
-0.242 \\
(0.375) \\
\end{array}$ \\
\hline \multicolumn{5}{|c|}{ PANEL B SUMMARY STATISTICS AND TEST STATISTICS ${ }^{2}$} \\
\hline $\begin{array}{l}\text { \# Firms } \\
\text { \# Observations }\end{array}$ & $\begin{array}{r}182 \\
1638 \\
\end{array}$ & $\begin{array}{r}182 \\
1638 \\
\end{array}$ & $\begin{array}{r}182 \\
1638 \\
\end{array}$ & $\begin{array}{r}182 \\
1638 \\
\end{array}$ \\
\hline $\begin{array}{l}\text { Joint significance } \\
\text { Sargan } \\
\text { SOSC }\end{array}$ & $\begin{array}{c}\chi^{2}(5)= \\
206.21^{* *} \\
\chi^{2}(32)= \\
37.82 \\
0.13\end{array}$ & $\begin{array}{c}\chi^{2}(5)= \\
185.82^{* *} \\
\chi^{2}(32)= \\
40.34 \\
-0.45\end{array}$ & $\begin{array}{c}\chi^{2}(5)= \\
208.38^{* *} \\
\chi^{2}(32)= \\
44.37 \\
0.14 \\
\end{array}$ & $\begin{array}{c}\chi^{2}(5)= \\
168.48^{* *} \\
\chi^{2}(32)= \\
42.89 \\
-0.26 \\
\end{array}$ \\
\hline $\begin{array}{l}\text { Zero tail adjustment } \\
\text { Zero incremental tail } \\
\text { adjustment } \\
\text { Symmetric tail } \\
\text { adjustment }\end{array}$ & $\begin{array}{c}\chi^{2}(2)= \\
200.98^{44} \\
\chi^{2}(2)= \\
0.60 \\
\chi^{2}(1)= \\
0.45\end{array}$ & $\begin{array}{c}\chi^{2}(2)= \\
178.89^{* *} \\
\chi^{2}(2)= \\
0.64 \\
\chi^{2}(1)= \\
0.08\end{array}$ & $\begin{array}{c}\chi^{2}(2)= \\
200.63^{* *} \\
\chi^{2}(2)= \\
0.11 \\
\chi^{2}(1)= \\
0.08\end{array}$ & $\begin{array}{c}\chi^{2}(2)= \\
154.24^{* *} \\
\chi^{2}(2)= \\
1.98 \\
\chi^{2}(1)= \\
0.08 \\
\end{array}$ \\
\hline
\end{tabular}

Notes: Random effects estimates of $\Delta$ Liquidity ${ }_{t}$ with Liquidity defined as before. Standard errors are robust to heteroskedasticity (cf. White, 1982) and reported in parentheses.

All variables are defined as before. Investment is treated as a potentially endogenous variable and is instrumented with its own level lagged one period. The interactions of $D^{\text {lows }}, D^{\text {mediturm }}$, and $D^{\text {hight with Deviation }}$, are also instrumented with one lag of their own level.

For notes on the test statistics see table 6.3. Significance at the 5 and 1 percent error level is indicated by " and ", respectively. 
Table A6.2

(A)symmetries in size: services firms (continued)

\begin{tabular}{|c|c|c|c|c|}
\hline \multicolumn{5}{|c|}{ PANEL A ESTMMATION RESULTS } \\
\hline $\begin{array}{l}\text { Independent } \\
\text { variables }\end{array}$ & $\begin{array}{c}(5) \\
=-70 \% \\
\text { highili }=+70 \%\end{array}$ & $\begin{array}{c}\text { (6) } \\
=-75 \% \\
=+75 \%\end{array}$ & $\begin{array}{c}(7) \\
\text { low }=-80 \% \\
\text { high }=-80 \%\end{array}$ & $\begin{array}{c}(8) \\
\text { tow } \\
\text { high }=-85 \% \\
=\end{array}$ \\
\hline Deviarion $_{t .+} \times D^{\text {lats }}$ & $\begin{array}{l}-0.912 \\
(0.090)\end{array}$ & $\begin{array}{l}-0.963 \\
(0.085)\end{array}$ & $\begin{array}{l}-1.020 \\
(0.109)\end{array}$ & $\begin{array}{l}-0.948 \\
(0.140)\end{array}$ \\
\hline Deviation ${ }_{t,-1} \times D^{\text {masditum }}$ & -0.440 & -0.507 & -0.594 & -0.671 \\
\hline Deviauion $\times D^{\text {hight }}$ & $\begin{array}{l}(0.317) \\
.0891\end{array}$ & $(0.202)$ & $(0.176)$ & $\begin{array}{l}(0.140) \\
-0.903\end{array}$ \\
\hline Deviation ${ }_{t, 4} \times D^{2,3 n}$ & $\begin{array}{l}-0.891 \\
(0.085)\end{array}$ & $(0.085)$ & $\begin{array}{l}-0.931 \\
(0.089)\end{array}$ & $(0.087)$ \\
\hline Cash flow, & 0.380 & 0.338 & 0.348 & 0.347 \\
\hline & $(0.143)$ & $(0.139)$ & $(0.143)$ & $(0.143)$ \\
\hline Investment, & -0.190 & $\begin{array}{l}-0.036 \\
(0.359)\end{array}$ & -0.106 & $\begin{array}{l}-0.113 \\
(0.366)\end{array}$ \\
\hline \multicolumn{5}{|c|}{ PANEL B SUMMARY STATISTICS AND TEST STATISTICS ${ }^{2}$} \\
\hline \multirow{2}{*}{$\begin{array}{l}\text { \# Firms } \\
\text { \# Observations }\end{array}$} & 182 & 182 & 182 & 182 \\
\hline & 1638 & 1638 & 1638 & 1638 \\
\hline \multirow{3}{*}{$\begin{array}{l}\text { Joint significance } \\
\text { Sargan }\end{array}$} & $x^{2}(5)=$ & $\chi^{2}(5)=$ & $\chi^{2}(5)=$ & $\chi^{2}(5)=$ \\
\hline & $\begin{array}{c}193.82 \\
x^{2}(32)=\end{array}$ & $\begin{array}{c}208.40^{\circ} \\
\chi^{2}(32)=\end{array}$ & $\begin{array}{l}217.20^{\circ} \\
\chi^{2}(32)=\end{array}$ & $\begin{array}{l}216.93 \\
x^{2}(32)=\end{array}$ \\
\hline & 41.36 & 33.96 & 33.28 & 34.14 \\
\hline SOSC & -0.17 & 0.23 & 0.55 & -0.12 \\
\hline \multirow{5}{*}{$\begin{array}{l}\text { Zero tail adjustment } \\
\text { Zero incremental tail } \\
\text { adjustment } \\
\text { Symmetric tail } \\
\text { adjustment }\end{array}$} & $\begin{array}{l}\chi^{2}(2)= \\
157.51^{m * *}\end{array}$ & $\begin{array}{l}\chi^{2}(2)= \\
182.35^{* *}\end{array}$ & $\begin{array}{l}\chi^{2}(2)= \\
135.08^{4 *}\end{array}$ & $\begin{array}{l}x^{2}(2)= \\
113.21^{*}\end{array}$ \\
\hline & $x^{2}(2)=$ & $\chi^{2}(2)=$ & $\chi^{2}(2)=$ & $x^{2}(2)=$ \\
\hline & 1.81 & 3.93 & 3.06 & 1.59 \\
\hline & $\chi^{2}(\mathbb{1})=$ & $\chi^{2}(1)=$ & $\chi^{2}(1)=$ & $\chi^{2}(1)=$ \\
\hline & 0.04 & 0.09 & 0.73 & 0.13 \\
\hline
\end{tabular}

Notes: Random effects estimates of $\Delta$ Liquidity, with Liquidity defined as before. Standard errors are robust to heteroskedasticity ( $\mathrm{cf}$. White, 1982) and reported in parentheses.

1 All variables are defined as before. Investment is treated as a potentially endogenous variable and is instrumented with its own level lagged one period. The interactions of $D^{d s w}, D^{\text {meditum }}$, and $D^{\text {htgh }}$ with Deviation ${ }_{t-l}$ are also instrumented with one lag of their own level.

2 For notes on the test statistics see table 6.3. Significance at the 5 and 1 percent error level is indicated by " and ", respectively. 


\section{Chapter 7 \\ Do Corporate Liquidity Holdings Provide Useful Measures of Financing Constraints?}

\subsection{Introduction}

In the previous chapters we have looked separately either at the corporate investment (chapters 2, 3, and 4) or the corporate liquidity decision (chapters 5 and 6) in an environment characterised by asymmetric information. As discussed extensively in chapter 2 and applied empirically in chapters 3 and 4 , asymmetric information has an important impact on the investment and financing decisions of the firm. It does so by making external funds more expensive than internal funds, resulting in non-separable investment and financing decisions. Empirical tests of financing constraints in corporate investment find that such informational issues make investment excessively: sensitive to (the accumulation of) internally available funds. By contrast, in the absence of any capital market frictions, expected investment profitability should be a sufficient statistic to explain corporate investment.

Liquid assets are a seemingly obvious pool of internal funds that can swiftly be directed towards the financing of new investment. Not surprisingly, therefore, the terms financing constraints and liquidity constraints are sometimes used interchangeably (e.g., Schaller, 1993), suggesting that firms with low levels of liquid balances are also the firms that face the most severe financing constraints. An exploration of this line of thinking is provided by Kaplan and Zingales (1997), KZ97 hereinafter, who substantially motivate a firm's constrained status by its reported liquidity position. The maintained hypothesis underlying the subsequent test on financing constraints is that firms with high levels of liquidity are least likely to have to resort to (expensive) external sources of funds to finance planned investment. Therefore, these are the firms for which investment is expected to be most sensitive to profitability considerations and least sensitive to changes in internal funds. Contrary to such conjecture, KZ97 find a non-monotonic relationship between liquidity holdings and the investment-cash flow sensitivity (ICFS). They conclude that the latter is not a useful measure of financing constraints. We do not agree with this reading of the evidence. Specifically, we do not think that observed corporate liquidity holdings are usefull measures of how constrained a firm is. Therefore we feel that ICFS patterns resulting from this particular maintained hypothesis have no meaning. 
In this chapter we present theoretical arguments and empirical evidence to make the case that observed liquidity holdings do not provide useful measures of financing constraints. We build on the analysis in chapters 5 and 6 , where we have demonstrated that the corporate liquidity decision itself is sensitive to problems of asymmetric information. Though costly to hold, liquidity offers benefits in a dynamic setting in the form of alleviating future financing constraints. Optimal, or targeted, corporate liquidity holdings therefore reflect the inter-temporal aspect of the liquidity decision; do we alleviate contemporary financing constraints (i.e. run down liquidity for the financing of contemporary investment) or do we alleviate future financing constraints (i.e. hoard liquidity and possibly behave constrained today despite apparent riches). As such, the (expected future) premium on external finance as well as uncertainty over the availability of external finance when it is most needed feed into a distinct precautionary motive to hold liquid assets. Supportive of such conjecture we have illustrated empirically for a sample of Dutch firms that corporate liquidity is an actively managed financial ratio and caninot be treated as an exogenous variable in the presence of informational problems in capital markets. As a result, the clear connection between liquid asset holdings and financing constraints is lost: high levels of corporate liquidity holdings no longer automatically signal an abundance of readily available internal means to finance investment. In fact, these high levels of liquid assets may actually result from a relatively large degree of informational problems, suggesting that firms with high liquidity ratios may actually be most likely to suffer from the incidence of external financing constraints. While this point has been recognised (e.g., Fazzari, Hubbard, and Petersen, 2000; Kaplan and Zingales, 2000) and demonstrated formally (e.g., Dasgupta and Sengupta, 2001), we are unaware of any empirical testing.

The main aim of this chapter is to analyse the connection between corporate liquidity holdings and financing constraints in corporate investment decisions when firms have information that investors do not have. Specifically, in this chapter we investigate the impact of liquid asset holdings on the severity of financing constraints while taking into account that liquidity holdings only partly reflect 'freely' investable internal funds. We explicitly take into account the theoretical motivations to hold a precautionary amount of liquid assets as well as the empirical result that liquidity is an actively managed financial ratio (cf. chapters 5 and 6). We then assess to what extent the ICFS is associated with differential liquidity targets and to what extent it is associated with deviations

1 Opler et al. (1999) consider the effect of targeted liquidity and target deviations on investment outlays. They do not, however, explore to what extent targets or deviations affect the separability of investment and finance. 
from these targets. We emphasise that the observed liquidity ratio - being the sum of a liquidity target and the deviation of actual liquidity from this target - is an imprecise indicator of the degree of financing constraints.

The chapter is organised as follows. Section 7.2 discusses the role of corporate liquidity holdings when the investment decision is made subject to financing constraints. First, in subsection 7.2.1 we discuss the KZ97 contribution, which strongly disseminates the idea that liquidity holdings measure financing constraints. Second, in subsection 7.2.2 we consider a simple moral hazard model of investment by Dasgupta and Sengupta (2001), DS01 hereinafter, which demonstrates that the connection between observed liquidity holdings and contemporary financing constraints depends on the degree of informational problems. In subsection 7.2.3, we discuss the implications of the DS01 model for the dynamic interaction between corporate liquidity holdings and corporate investment. We conclude in subsection 7.2.4 with the presentation of the hypotheses that we test empirically for the remainder of the chapter. In section 7.3 we introduce the data and outline our empirical strategy. In section 7.4 we present and discuss our results. Section 7.5 summarises and concludes.

\subsection{Liquidity and investment under financing constraints}

\subsubsection{Liquidity and financing constraints: $K Z 97^{2}$}

KZ97 relate internal wealth directly to financing constraints within the framework presented before in chapter 2 and embodied in figure 2.1. Figure 7.1 illustrates their argument. In the figure, investment demand $(t / \kappa)$ is a negative function of $q$, the market value of investment relative to its replacement cost. Internal funds will finance any project for which $q>1$. External providers of finance command a premium, $f$ (assumed to be driven to an important extent by problems of asymmetric information). When financed with external means, therefore, an investment project can be profitably financed only when $q \geq 1 / 1-f>1$. For a given set of investment opportunities as well as the premium $f$, the ICFS can be seen to relate to the level of funds internally available for

$2 \quad$ KZ97 provide the most prominent expression of the more general feeling of discomfort concerning some of the findings in the empirical literature on financing constraints in corporate investment. The prominence of their analysis stems from the fact that it uses the 49 low-dividend pay-out firms in FHP88, while the latter study is considered to be the parent of all papers in this literature. A debate followed in The Quarterly Journal of Economics of May 2000, with contributions by FHP and KZ. 
investment. ${ }^{3}$ In figure $7.1 \mathrm{~A}$, a situation of abundant internal resources relative to investment demand is depicted. Here we expect the firm to behave unconstrained, suggesting that its investment is insensitive to changes in intemal funds. In figure $7.1 \mathrm{~B}$, however, internal resources are low relative to investment demand. Here the firm is constrained in the sense that profitable projects have to be passed up because they require finance with costly external funds. Hence we expect investment to be sensitive to changes in internal funds in this instance.

\section{Figure 7.1}

Liquidity and financing constraints: KZ97

(A)
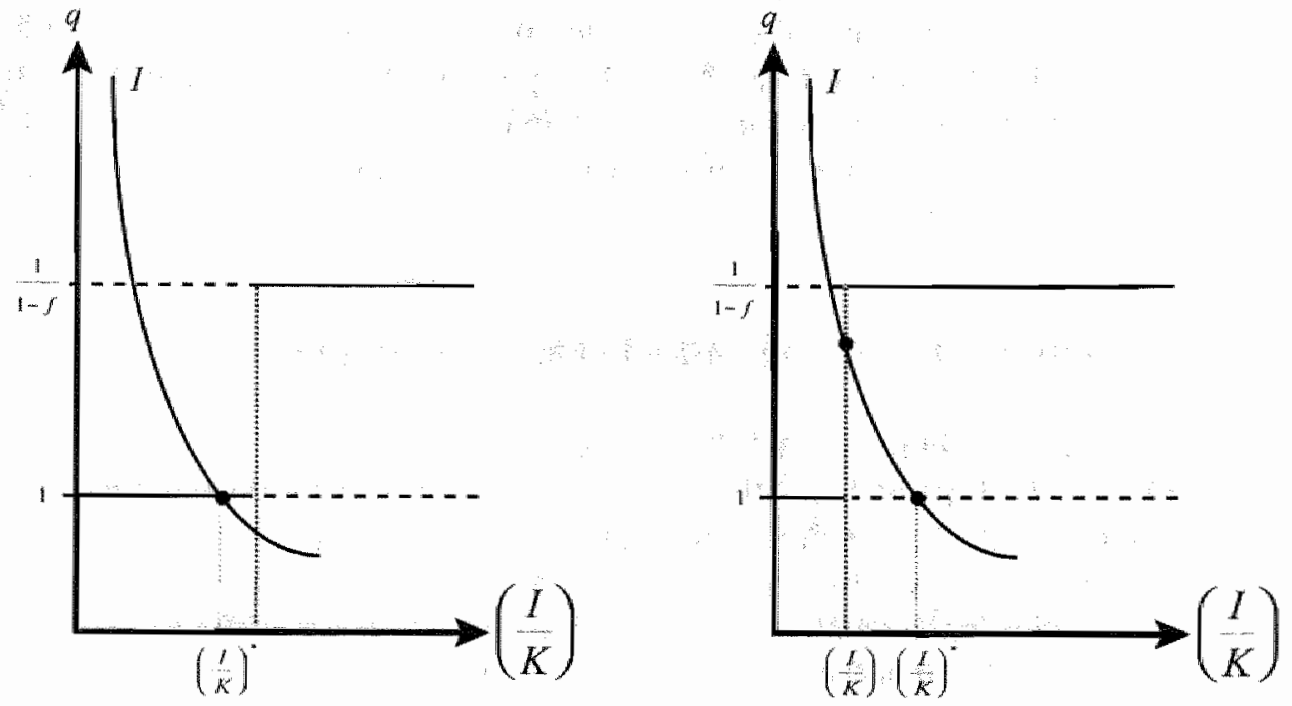

For the empirical testing of their argument KZ97 classify firms on the basis of internally available means. For the classification of firms, major importance is given to a firm's reported liquidity position. Specifically, KZ97 classify firms as definitively not financially constrained (NFC), likely not financially constrained (LNFC), possibly financially constrained (PFC), likely financially constrained (LFC), or undoubtedly financially constrained (FC). They classify as NFC or LNFC a firm that "had more liquidity than it would

3 The KZ97 theoretical model indicates that this conclusion depends also on the assumed curvature of the funds supply schedule as well as the investment demand curve. 
need for investment in the foreseeable future" (KZ97, p. 180) or had "sizable cash reserves [and] unused lines of credit" (op. cit., p. 181). PFC firms are those that "are not explicitly strapped for cash" (ibid.), but "do not look particularly liquid either" (ibid.). LFC firms are those that "have little cash avalable" (ibid.), while FC firms "declare that they are forced to reduce investments because of liquidity problems" (op. cit., p. 182). When confronted with the data it appears that the ICFS is not monotonic in the liquidity of the firm. KZ97 conclude that their empirical evidence is not supportive of the notion that investment-cash flow sensitivities are useful measures of financing constraints.

We do not agree. For the remainder of the chapter we develop and test empirically the claim that a firm's reported liquidity holdings are not useful measures of financing constraints. A crucial (implicit) assumption in KZ97's reasoning is that all of the firm's reported liquidity is readily available for the financing of contemporary investment. Put differently, the joint assumption is that the decision horizon of the firm does not stretch into the future (making any precautionary liquidity holdings superfluous) and that liquidity in itself has no value to the firm (for instance to facilitate transactions or to prevent costly liquidation). The analysis becomes more complicated when we allow for the explicit formulation and pursuit of liquidity targets motivated by - among other factors - the same informational problems that underlie financing constraints. To illustrate this complexity, consider KZ97's discussion of unconstrained firms as those with "low debt and high cash [which could] have invested appreciably more if their managers had so chosen [emphasis in the original]" (ibid.). Nevertheless, the descriptive statistics in KZ97 show that these firms also have the most profitable investment opportunities. What KZ97 cannot explain and we can is why these firms did not act on profitable investment opportunities despite their apparent riches. In the following subsection we do so by considering a simple, static investment model with moral hazard. There we show that large holdings of liquidity ameliorate contemporary financing constraints only for a given degree of informational problems. Hence liquidity holdings may be large in absolute terms, but small relative to informational asymmetries, leading to financially constrained, cash-rich firms. In subsection 7.2.3 we consider the dynamic implications of the corporate liquidity decision. There we argue that a stronger degree of informational problems motivates larger precautionary liquidity holdings. Hence liquidity holdings may be large in anticipation of future financing constraints and not freely spendable to alleviate contemporary constraints. 


\section{2 .2 A static analysis of liquidity and investment}

Consider the DS01 investment model with moral hazard. At the start of period $t$ firms face a new investment opportunity that requires a unit cost investment, generates cash flow $a>0$ at the end of period $t$ when successful (with probability $p$ ) and nothing when it fails. The earnings potential of a project $(a)$ is drawn from a continuous distribution $F(a)$ with support $[a, \bar{a}]$, but is common knowledge at the time the firm seeks outside finance in the form of debt. ${ }^{4}$ The firm always has the option to invest in a negative net present value (NPV) project that requires the same unit cost investment, but yields private benefits $B$ with certainty, where $0<B<1$. The firm furthermore carries liquid assets in the amount of $x$ over from period $t /$. It uses a mix of these liquid assets and debt to finance investment.

Typically $x<1$, making outside finance a sine qua non for exploiting any investment opportunity. When supplying debt, creditors require that the firm does not invest in the unproductive project. Hence $p[a-d] \geq B$ must always be satisfied, where $d$ denotes the face value of the loan. Competitive lending markets furthermore imply that $p d=1-x$. Thus the firm's incentive compatibility constraints is $p\left[a-\frac{1-x}{p}\right] \geq B$, which defines the marginal state in which the firm can invest as a function of cash carried over from the past:

$$
a_{x}=\frac{B}{p}+\frac{1-x}{p}
$$

Now let us define $a^{*} \equiv y_{p}$ as the worst project state in which the firm would possibly invest in the absence of moral hazard issues (i.e. NPV $=0$ ). We define that a firm is unconstrained if it can always invest in any project for which $a \geq a^{*}$. In contrast, the firm is constrained for $B>0$ and $x<B$ in the sense that it cannot finance all profitable projects. The value of liquidity then lies in the fact that it widens the scope of profitable projects in which the firm is able to invest. Put differently, for a given degree of informational problems $(B)$ equation (7.1) readily shows that an increase in $x$ ameliorates contemporary financing constraints. For any given level of $x$, however, the extent to which a firm is financially constrained depends on $B$.

The relation between $x, B$, and $a_{x}$ is shown in figure 7.2. Depending on the possible combinations of $x$ and $B$ we distinguish three zones of financing constraints. First, for any $x \geq B$ equation (7.1) readily shows that all projects

4 The success probability $p$ is assumed to be the same for all $a$ drawn from $F(a)$.

5 The idea that the contribution of own (liquid) funds to a project alleviates moral hazard problems in itself is not new. See for instance Holmström and Tirole $(1997,1998)$ or Bolton and Freixas (2000) for similar modelling of investment with moral hazard. 
with nonnegative present value can be started. In figure 7.2 combinations of $x$ and $B$ satisfying this requirement are indicated by the upper left shaded area. The firm is unconstrained in these situations. Second, for any $x<B-(p a-1)$ the firm is unable to initiate even the most profitable investment opportunity. In such situations, indicated in figure 7.2 by the lower right shaded area, the firm is completely constrained from initiating any contemporary investment by lack of liquid assets. Third, for $B-(p \bar{a}-1) \leq x<B$ the firm can initiate some, but not all profitable investment opportunities. In these instances, indicated in figure 7.2 by the non-shaded corridor, we label the firm partially constrained.

\section{Figure 7.2}

Informational problems, liquidity holdings, and financing constraints

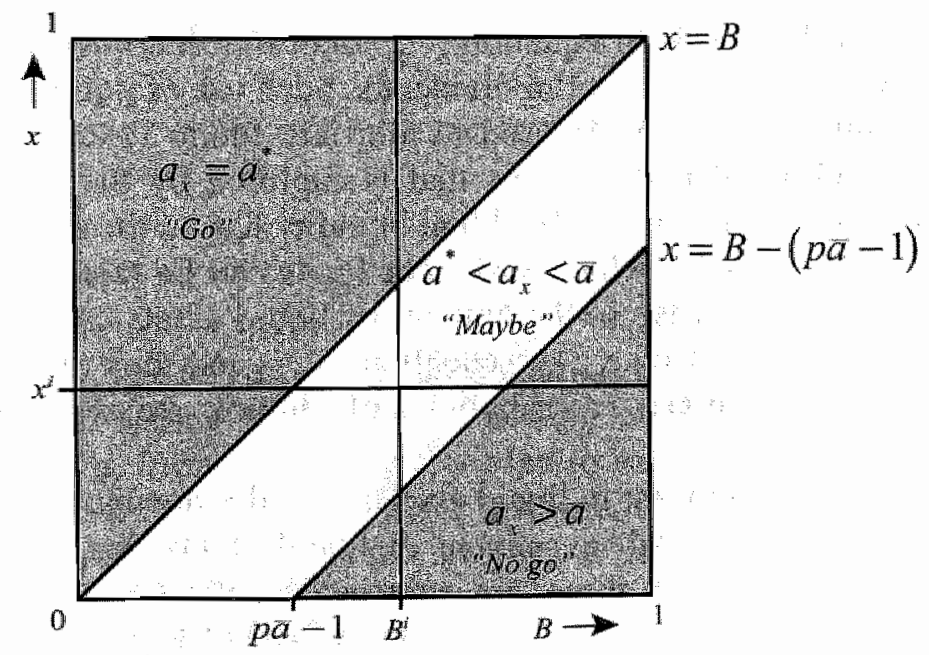

The important realisation to take away from figure 7.2 pertains to the connection between the observed level of corporate liquidity holdings and the financing constraints the firm is subject to: there is none. Liquidity holdings $x^{\prime}$, for instance, can be associated with a completely unconstrained firm (for low $B$ ), a partly constrained firm (for intermediate $B$, like $B^{i}$ in the figure), or a completely constrained firm (for high $B$ ). Hence in a static context, observed liquidity holdings are not useful measures of financing constraints.

\subsubsection{A dynamic analysis of liquidity and investment}

So far we have disregarded the question where contemporary liquidity holdings come from. In fact, the static analysis in the previous subsection yields identical results when we model liquidity holdings as manna from heaven. In a dynamic framework, however, liquidity holdings in period $t$ stem from conscious 
decisions in period $t-1$. To illustrate the dynamic aspects of the corporate liquidity decision in a financing constraints setting, we follow DS01 and consider again their investment model with moral hazard outlined in the previous subsection. Now let $A_{x}=\min \left[a, \max \left[a_{x}, a^{*}\right]\right]$ be the threshold value of project profitabillity where the firm is just willing and able to initiate the project: In essence, then, $A_{x}$ is the investment trigger: the firm wants to invest in any project for which $a \geq a$, it can raise sufficient funds to initiate any project for which $a \geq A_{x}$, so that it initiates any project for which $a \geq A_{x}$ since $A_{x} \geq a$ "by definition. The ex ante gross value of carrying $x$ in liquid balances from the present into the future, $P(x)$, is then given by

$$
P(x)=\int_{A_{x}}^{\alpha}[p a-1] d F(a)+x
$$

The second term on the right-hand side of equation (7.2) indicates that liquidity carried into the future can always be paid out in dividends. Such use of liquidity makes a zero NPV investment. If $x$ can be used to alleviate future financing constraints, however, an additional gain accrues that is captured by the first term. This term represents the expansionary effect that liquidity has on the set of profitable investment opportunities for which sufficient funds can be raised to initiate them. That is to say, an increase in the amount of liquid assets carried into the future reduces $A_{x}$ - by lowering $a_{x}$, see equation 7.1 - and thus raises the expected payoff from a given distribution of future investment opportunities. ${ }^{6}$

To formalise the incentive to invest in liquid assets, consider the marginal value of hoarding liquidity: $\partial P(x) / \partial x$. An investment in liquid assets does not create value when it cannot affect the future investment decision $\left(A_{x}\right)$. This happens when $A_{x}=a$, but also when $A_{x}=a$ and the increment to liquidity does not lower $A_{x}$ below $a$. In the former situation, the firm already carries $x \geq$ $B$ into the future. This implies that in the future the firm is completely unconstrained already and any incremental investment in liquidity is redundant. In the latter situation, the firm carries $x<\eta \equiv B-(p \bar{a}-1){ }^{8}$ The firm is then completely constrained in the future and any addition to liquidity that fails to

6 For the moment we follow DSOl and consider a single future period. We elaborate on the case with multiple future periods shortly.

Note that for $B=0$ investments in liquid assets never create value. Hence the motivation to consciously make such investments stems solely from informational problems.

"It is possible that $\eta \leq 0$. Then, $a_{x} \leq a$ for $x=0$. We focus only on the case where $a_{0}>a$ and, consequently, $\eta>0$. That is, we assume that $B=B^{i}$ for instance, in figure 7.2 . 
raise $x$ above $\eta$ cannot alter this prospect. Only for $\eta \leq x<B$ does an incremental investment in liquid assets expand the future set of feasible investment opportunities and thus create value. Figure 7.3 summarises these results. It follows logically that firms will never plan to carry liquidity short of $\eta$ or exceeding $B$ into the future. In fact, when a firm cannot manage to carry at least $x=\eta$ into the future, it will prefer to set $x=0$ and use all of its liquidity to expand the range of feasible contemporary investment opportunities. The same goes for firms that are able to hoard $x>B$ in liquid assets; these firms will plan to carry at most $x=B$ and use the remaining $x-B$ to (further) ameliorate contemporary financing constraints.

\section{Figure 7.3}

The value of carrying liquidity from the present into the future

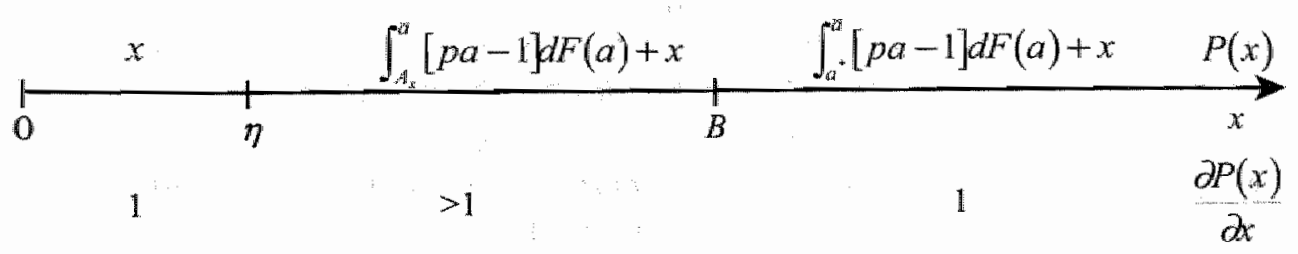

The incentives to hoard liquidity are refined when we extend the DSO 12 period setting to a future consisting of many periods (years). Then, forwardlooking firms may optimally plan to carry $x>B$ into the next period. Optimal liquidity holdings of $2 B$, for instance, allow the firm to invest in all profitable states next year and still carry $x=B$ into the year after that, regardless of next year's cash flow. Optimal, or targeted, liquidity holdings are therefore (among other factors) dependent on the degree of impatience of the firm. The more patient the firm, the stronger its relative emphasis will be on alleviating future financing constraints, which results in higher levels of targeted liquidity. ${ }^{10}$ As such, "[w] hile it may be momentarily feasible for a firm to invest more in the current period by consuming more or all of its cash, it may rationally choose to

- Of course, firms may still end up with very low or high liquidity holdings when they cannot profitably employ them at present. Also see DS01 for a discussion of how firms can be very constrained at present and end up carrying a large amouint of liquidity into the future.

10 Contrary to the DSO1 2-period setting, liquidity holdings short of being useful in period $t+1(x<\eta)$ may now also be willingly carried into period $t+1$. This results from the opportunity to raise these holdings in the near future $(\mathrm{e} . \mathrm{g}, 1+1)$ to a level that is useful in the more distant future (e.g., $t+2)$. 
preserve cash for self-financing in periods when the flow of internal funds is low, perhaps even negative" (Fazzari et al., 1996, pp. 24-25).

If financing constraints are a fact of life not only at present, but also in the future, then clearly the idea that corporate liquidity is used solely for alleviating contemporary financing constraints is too simple. In such situation, "[florward-looking firms: will [...] partially protect themselves [against future financing restrictions] with buffer stocks of cash [...]. The more financially constrained a firm is, the greater is its incentive to accumulate liquid buffer stocks" (Fazzari et al., 2000, p. 701). As we have illustrated empirically in chapters 5 and 6 , informational asymmetries generate uncertainty over the future access to external funds and produce a precautionary motive to hold liquid balances. This notion of precautionary liquidity holdings further blurs the interpretation of observed levels of liquidity as an indicator of financing constraints. It implies that those firms for which informational problems are most severe are the ones that have the strongest motive to accumulate precautionary balances. Thus high levels of liquidity "may indicate the presence rather than the absence of constraints in a dynamic setting where financially constrained firms use cash stocks to buffer their investment against future financial restrictions" (Fazzari et al, 1996, p. 2).

\subsubsection{Empirical hypotheses}

We claim that observed levels of corporate liquidity holdings are not useful measures of financing constraints. In a static setting we demonstrated in subsection 7.2.2 that financing constraints relate to liquidity holdings relative to the degree of informational problems. In a dynamic setting, we cannot use observed liquidity holdings to measure financing constraints, because this "ignores firms" incentives to maintain [...] precautionary cash stocks that can be used to partially offset shocks to the flow of internal finance" (Fazzari et al., 1996, p.2). Hence we do not expect variations in observed liquidity holdings to structurally relate to financing constraints.

Optimal, or targeted liquidity holdings reflect a firm's trade off between using liquidity for alleviating contemporary financing constraints and hoarding it for alleviating expected future financing constraints. Targeted liquidity holdings thus provide information on contemporary financing constraints only relative to expected future constraints. As such, they too are uninformative regarding the absolute degree of contemporary financing constraints.

We hypothesise that excesses or shortages of liquidity relative to targeted levels indeed provide useful measures of financing constraints. In that regard, we agree with KZ97 that " $[i] t$ seems reasonable to assume that firms with less 
slack are more financially constrained than firms with more slack" (p. 201)." More specifically, when liquidity holdings are large relative to targeted holdings, then the firm is able to assign a larger fraction of the stock of liquid assets to the task of relaxing contemporary financing constraints without compromising its ability to ameliorate future financing constraints. Consequently, contemporary investment outlays should be less dependent on expected cash inflows when the firm has positive slack. Similarly, for low levels of liquidity holdings relative to targeted levels, it is conceivable that a smaller part of the remaining stock of liquid assets is available for relaxing contemporary financing constraints. Contemporary investment should then depend more strongly on expected inflows of cash.

\subsection{The empirical strategy}

\subsubsection{Characterising the corporate investment decision}

The empirical investment model that we use to test these hypotheses is similar to the one used in the analysis of financing constraints in chapter 3 . The empirical investment equation is

$$
\begin{aligned}
& \frac{I_{i t}}{A_{i, t-1}}=\beta_{0} \frac{I_{i, t-1}}{A_{i, t-2}}+\beta_{1} \Delta y_{i t}+\beta_{2} \ln \frac{Y_{i t}}{A_{i, t-1}} \\
& \quad+\beta_{3} \frac{C f_{i t}}{A_{i, t-1}}+\beta_{4} \frac{\Delta W c_{i t}}{A_{i, t-1}}+\lambda_{t}+\eta_{i}+v_{i t} \quad \text { (equation (3.2) repeated) }
\end{aligned}
$$

where the variables are indexed by firm $(i)$ and year $(t), \lambda_{t}$ and $\eta_{i}$ capture timeand firm-specific random effects, respectively, and $v_{i t}$ is a white-noise error term with the usual properties. $I$ measures investment in fixed assets, $A$ stands for end-of-year total assets, $Y$ denotes sales, $\Delta y$ the growth rate of sales, $C f$ measures cash flow as earnings after interest and taxes, but before depreciation and dividend payments, and $\Delta W c$ denotes investment in working capital, measured as investments in cash, inventories, and short-term claims less-short term debt. As before in chapter 3, we focus on the sensitivity of corporate investment to cash flow to detect the presence of financing constraints. Specifically, we expect investment to be more sensitive to the inflow of cash when corporate liquidity holdings fall short of targeted levels and vice versa. In order to associate differences in the ICFS with differences in financing

II It is their measure of slack that we do not agree with, however. Specifically, theirs is defined as the sum of observed liquidity holdings and any unused lines of credit. Ours is the difference between observed and targeted liquidity holdings. 
constraints, we interact cash flow with dummy variables that contain information on the deviation of a firm's observed liquidity from targeted levels. We now turn to the definition of targeted liquidity holdings and target deviations.

\subsubsection{Classifications using liquidity, targets, and target deviations}

We use as empirical measures of targeted liquidity holdings the firm-specific liquidity targets computed in section 5.4. This provides us with estimates of targeted liquidity - and consequently target deviations - for a balances panel of 473 large non-financial Dutch firms for the period 1986-1997. For a more elaborate discussion of the data refer to section 5.3 .

When classifying firms as constrained or unconstrained based on their observed liquidity holdings relative to target we must address the following two issues. First, we must take into account our empirical results from the previous chapter. Specifically, there we observe that corporate liquidity is an actively managed financial ratio and adjustment to targeted liquidity is particularly fast (and target deviations particularly short-lived) when liquidity strays far away from the target. Rapid target adjustment suggests that a classification methodology with once-and-for-all allocation of firms to constrained and unconstrained regimes is prone to confounding effects of firms switching between the two regimes during the estimation period. Consequently, the classification methodology employed in chapter 3 - using a classification period to assign a constrained or unconstrained status to firms for the entire estimation period - is not appropriate here. ${ }^{12}$ Instead, we opt for a methodology in the spirit of Bond and Meghir (1994) and sort out constrained and unconstrained firms in period $t$ based on information from period $t-l$. As such we allow firms to be constrained in some of the sample years, but unconstrained in others. ${ }^{13}$ This methodology furthermore corresponds with our analysis of corporate liquidity adjustment in the previous chapter, where the incentive to adjust derived from the end-of-previous-period target deviation.

Second, we must be aware of the absence of a theoretical measure of how far liquidity must deviate from the target to make a firm's investment decision more (or less) constrained. In the previous chapter we document a range of

i2 Specifically, we know from the previous chapter that excesses and shortages of liquidity relative to the target may disappear within the spell of a few years only. Hence the choice in chapter 3 for a 5 -year estimation period may already exhibit too much switching when we consider liquidity target deviations.

13 Also see Schiantarelli (1996) for a strong recommendation in favour of classification methodologies that allow for such switching. 
Table 7.1

Classifications of firms based on liquidity, targets, and target deviations

\begin{tabular}{|l|rr|rr|rr|}
\hline & \multicolumn{2}{|c|}{ Liquidity holdings } & \multicolumn{2}{|c|}{ Targeted liquidity } & \multicolumn{2}{|c|}{ Target deviations } \\
\cline { 2 - 7 } & \multicolumn{1}{|c|}{ Count } & \multicolumn{1}{c|}{$\%$} & Count & $\%$ & Count & $\%$ \\
\hline Low $(\leq-10 \%)$ & 1841 & 43.2 & 1978 & 46.5 & 1786 & 42.0 \\
Medium & 151 & 3.6 & 182 & 4.2 & 367 & 8.6 \\
High $(\geq+10 \%)$ & 2265 & 53.2 & 2097 & 49.3 & 2104 & 49.4 \\
\hline Low $(\leq-20 \%)$ & 1755 & 41.2 & 1855 & 43.6 & 1572 & 36.9 \\
Medium & 219 & 6.9 & 387 & 9.1 & 751 & 17.7 \\
High $(\geq+20 \%)$ & 221. & 51.9 & 2015 & 47.3 & 1934 & 45.4 \\
\hline Low $(\leq-30 \%)$ & 1676 & 39.4 & 1702 & 40.0 & 1346 & 31.6 \\
Medium & 439 & 10.3 & 622 & 14.6 & 1.138 & 26.8 \\
High $(\geq+30 \%)$ & 2142 & 50.3 & 1933 & 45.4 & 1773 & 41.6 \\
\hline Low $(\leq-40 \%)$ & 1579 & 37.1 & 1550 & 36.4 & 1126 & 26.5 \\
Medium & 606 & 14.2 & 845 & 19.9 & 1495 & 35.1 \\
High $(\geq+40 \%)$ & 2072 & 48.7 & 1862 & 43.7 & 1636 & 38.4 \\
\hline Low $(\leq-50 \%)$ & 1470 & 34.5 & 1400 & 32.9 & 947 & 22.2 \\
Medium & 7775 & 18.2 & 1073 & 25.2 & 1802 & 42.4 \\
High $(\geq+50 \%)$ & 2012 & 47.3 & 1784 & 41.9 & 1508 & 35.4 \\
\hline Low $(\leq-60 \%)$ & 1330 & 31.2 & 1231 & 28.9 & 761 & 17.9 \\
Medium & 963 & 22.7 & 1304 & 30.6 & 2089 & 49.0 \\
High $(\geq+60 \%)$ & 1964 & 46.1 & 1722 & 40.5 & 1407 & 33.1 \\
\hline Low $(\leq-70 \%)$ & 1176 & 27.6 & 1019 & 23.9 & 550 & 12.9 \\
Medium & 1158 & 27.2 & 1570 & 36.9 & 2411 & 56.7 \\
High $(\geq+70 \%)$ & 1923 & 45.2 & 1668 & 39.2 & 1296 & 30.4 \\
\hline Low $(\leq-80 \%)$ & 941 & 22.1 & 737 & 17.3 & 363 & 8.5 \\
Medium & 1435 & 33.7 & 1900 & 44.6 & 2700 & 63.5 \\
High $(\geq+80 \%)$ & 1881 & 44.2 & 1620 & 38.1 & 1194 & 28.0 \\
\hline
\end{tabular}

Notes: Observations are allocated to the Low (High) group when their liquidity holdings, targeted liquidity or target deviations, respectively, fall short of (exceed) the reference level by $x$ percent or more in period $t-1$, where $x$ is given in brackets. They are allocated to the Medium group otherwise. The reference level for liquidity holdings and targeted liquidity is the sample average of $3.08 \%$ (the exponent of average Liquidity, also see figure 6.3 ). The reference level for target deviations is the firm's liquidity target. The column headed by 'Count' provides the number of times, during the period 1989-1997, we observe a particular Low, Medium, or High liquidity position in $t-1$. The column headed by ${ }^{\prime} \%{ }^{\prime}$ expresses this as the share of the 4257 observations in total.

inaction when liquidity holdings are in a range of some 70 percent of the target. Outside this range, liquidity adjustment rapidly increases in importance and we 
claim that under such circumstances the liquidity decision takes precedence over other financial and real decisions, such as for instance the investment decision. But to say that the corporate liquidity decision apparently takes no precedence over the investment decision for sufficiently small target deviations is not the same as to say that it does not affect the investment decision nonetheless. We therefore compute ICFS patterns for a range of possible classifications of target deviations. Specifically, we consider first the investment behaviour of firms for which liquidity is 10 percent or more above the target ('high' liquidity) and below the target ('low' liquidity) relative to that of firms for which it is in a 10 percent range of the target ("medium' liquidity). We then increase the requirements for low and high liquidity positions with increments of 10 percent until we consider as low (high) those holdings that fall short of (exceed) the target by 80 percent or more.

The resulting classifications of observations to low, medium, or high target deviations are shown in the third column of table 7.1. The first two columns present similar classifications based on observed liquidity holdings and targeted levels, respectively. ${ }^{14}$ Note that the number of firms actually allocated to the 'low" and 'high' groups differs substantially although the classification criteria are symmetric in all instances. This reflects once more the asymmetry of the distributions of liquidity holdings, targeted holdings, and target deviations when expressed in absolute, rather than logarithmic levels (also refer to the discussion in section 6.5 in this regard). We use these classifications and associated ICFS patterns in the next section to compare with the patterns obtained from our classification based on target deviations.

\subsection{Estimation results}

\subsubsection{Target deviations and the ICFS}

Investment equation (7.3) is estimated with interaction dummies on cash flow and the results of this exercise are presented in table 7.2. Let us first discuss the results in columns (1) through (5) and then discuss our findings in the last three columns.

When corporate liquidity holdings stray away from targeted levels to up to 50 percent, we observe that the investment decision is rather insensitive to

14. Classifications are presented for the 1989-1997 period, which coincides with the period for which estimates of the investment equation are computed. Inclusion of lagged investment; first-differencing in the estimation procedure to remove firm-specific effects, and; the requirement that at least investment lagged two periods is available as an instrument each consume one year of data. 
cash inflows. More specifically, the parameter estimate on Cash flow is small and the statistical test that its true value is equal to zero cannot be rejected at conventional levels of confidence in the first five columns of the table. This suggests that firms separate investment from financing decisions when liquidity is only moderately far removed from target. Similar findings in columns (1) through (5) apply to firms who are far above target. The positive parameter estimates on the interaction terms $D^{\text {High }} \times$ Cash flow in the first four columns reveal some excess sensitivity of investment to cash inflows for these firms. However, statistical significance is lacking and we cannot reject the hypothesis that cash flow bears no additional relation to investment. Hence we conclude that firms with liquidity holdings far above target behave as unconstrained as do firms that are only moderately far above target.

When liquidity falls far short of targeted levels, however, we observe in columns (1) through (5) a positive and significant excess sensitivity of investment to cash flow. This finding is in line with our conjecture that negative slack makes investment more sensitive to cash inflows. Note that shortfalls of liquidity of this magnitude are not yet large enough to incite a determined upward adjustment in liquidity holdings. ${ }^{15}$ Nevertheless, firms in such a situation are apparently already reluctant to free up (additional parts of) their stocks of liquid assets for the financing of contemporary investment.

The results in columns (1) through (5) thus reveal a monotonic relationship between the ICFS and the deviation of observed from targeted liquidity holdings. In columns (6), (7), and (8) we consider the ICFS for liquidity holdings that deviate from the target by 60,70 , and 80 percent or more, respectively. As a corollary, we include ever larger deviations in our reference category of moderate deviations. At the same time, the liquidity positions far short and far in excess of the target become increasingly atypical. This produces some interesting differences with the results discussed so far.

First, we observe how excess sensitivity drops sharply and turns significantly negative in column (6) for frrms with liquidity holdings far above targeted levels. This excess sensitivity remains significantly negative also in columns (7) and (8) and seemingly supports our hypothesis that firms with positive slack are less constrained than firms with no or negative slack. Note, however, how the reference ICFS for firms with moderate target deviations turns positive and significant in column (6) and remains similar in size and significance throughout columns (7) and (8). In terms of absolute ICFS, therefore, nothing really happened to the firms with excessive liquidity

15 Recall from the previous chapter that liquidity holdings are more or less free to vary within a range of 70 percent of the target. 


\section{Table 7.2}

Target deviations and the investment-cash flow sensitivity

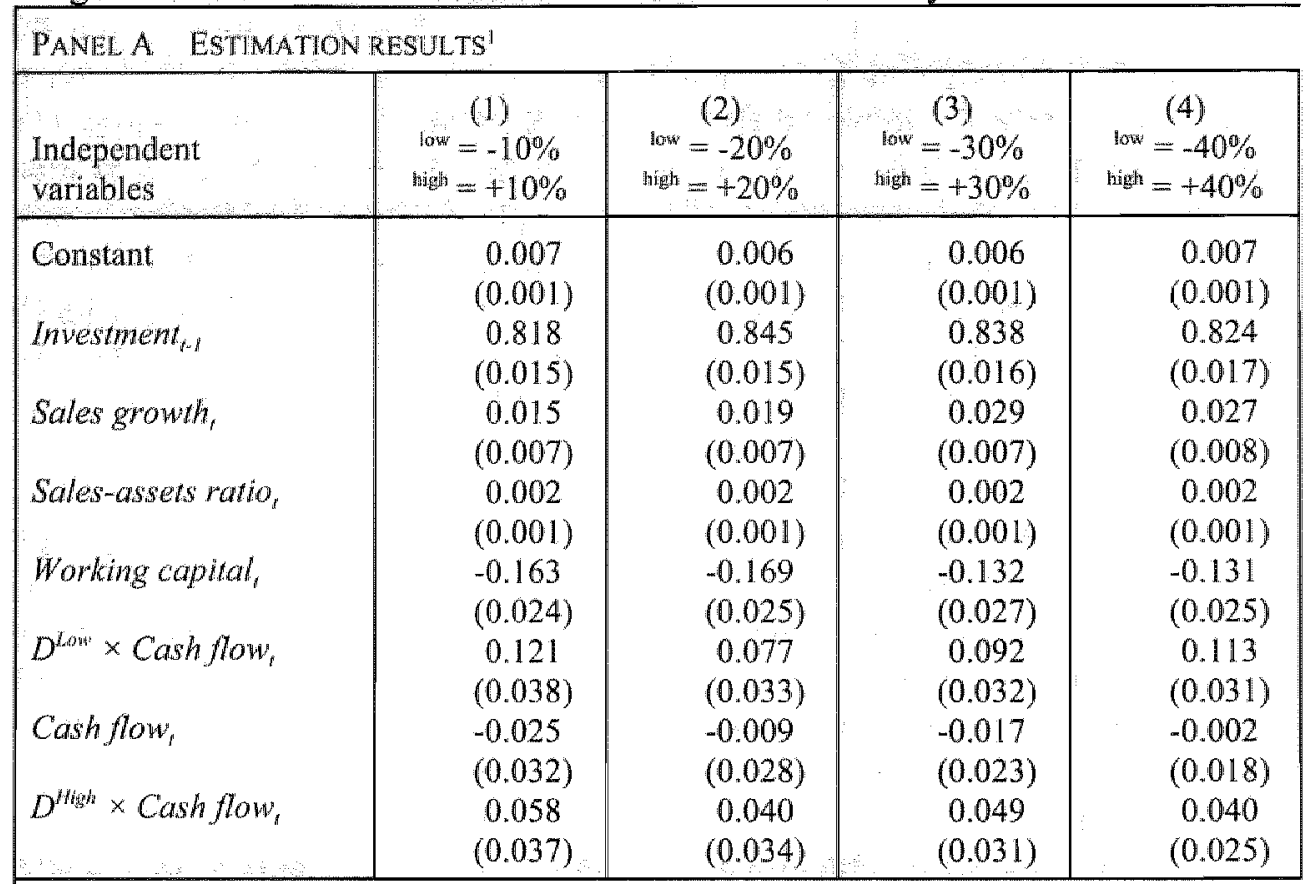

PANEL B SUMMARY STATISTICS AND TEST STATISTICS ${ }^{2}$

\begin{tabular}{|l|r|r|r|r|}
\hline \# Firms & 473 & 473 & 473 & 473 \\
\# Observations & 4257 & 4257 & 4257 & 4257 \\
Joint significance & $\chi^{2}(7)=$ & $\chi^{2}(7)=$ & $\chi^{2}(7)=$ & $\chi^{2}(7)=$ \\
& $5086.41^{* *}$ & $6186.91^{* *}$ & $4541.98^{* *}$ & $4469.25^{* *}$ \\
Sargan & $\chi^{2}(143)=$ & $\chi^{2}(143)=$ & $\chi^{2}(143)=$ & $\chi^{2}(143)=$ \\
& 142.55 & 154.80 & 152.09 & 146.65 \\
SOSC & -1.03 & -1.13 & -1.15 & -1.07 \\
DS $\left(\mathrm{Y}_{\mathrm{t}-2}\right)$ & $\chi^{2}(8)=$ & $\chi^{2}(8)=$ & $\chi^{2}(8)=$ & $\chi^{2}(8)=$ \\
DS $\left(\mathrm{X}_{\mathrm{t}-1}\right)$ & 6.34 & 9.28 & 8.35 & 9.29 \\
& $\chi^{2}(45)=$ & $\chi^{2}(45)=$ & $\chi^{2}(45)=$ & $\chi^{2}(45)=$ \\
& 34.18 & 39.03 & 38.31 & 37.83 \\
\hline
\end{tabular}

Notes: Random effects estimates of Investment $t_{r}$ (the change in fixed assets due to purchase or 1 Sales growth is the first difference of the log of sales; Sales-assets ratio is the log of short-term claims less short-term debt relative to assets; Cash flow measures earnings dummy that takes value I when Liquidity $y_{t-1}$ deviates from the target by more than the percentage deviation of Liquidity fr. $_{\text {fom }}$ the target. The instrument set consists of ratio, Cash flow, and $D^{\text {Luw }}$ (righ) $\times$ Cash flow lagged one, two, and three periods.

2 Joint significance of all variables in the model is tested with a Wald test; Sargan tests for second order autocorrelation and is based on estimates of the residuals in the instrument set as $Y_{1-2,}, Y_{t-3,3}, X_{t-1,}, X_{t-2}, X_{1-3}$ (with $X$ the vector of explanatory restrictions. Significance at the 5 and 1 percent error level is indicated by " and ", 


\begin{tabular}{|c|c|c|c|c|}
\hline $\begin{array}{c}(5) \\
\text { low }=-50 \% \\
\text { high }=+50 \%\end{array}$ & $\begin{array}{c}(6) \\
\text { loww }=-60 \% \\
\text { high }=+60 \%\end{array}$ & $\begin{array}{c}(7) \\
\text { low }=-70 \% \\
\text { high }=+70 \%\end{array}$ & $\begin{array}{c}(8) \\
\text { thaw }=-80 \% \\
\text { thigh }=+80 \%\end{array}$ & $\begin{array}{l}\text { Independent } \\
\text { variables }\end{array}$ \\
\hline 0.007 & 0.007 & 0.006 & 0.006 & Constam \\
\hline$(0.001)$ & $(0.001)$ & $(0.001)$ & $(0.001)$ & \\
\hline 0.827 & 0.814 & 0.843 & 0.843 & Investment $t_{n-1}$ \\
\hline$(0.016)$ & $(0.016)$ & $(0.016)$ & $(0.016)$ & \\
\hline 0.027 & 0.026 & 0.027 & 0.035 & Sales growth \\
\hline$(0.008)$ & $(0.008)$ & $(0.008)$ & $(0.009)$ & \\
\hline 0.002 & 0.002 & 0.002 & 0,002 & Sales-assets ratio \\
\hline$(0.001)$ & $(0.001)$ & $(0.001)$ & $(0.001)$ & \\
\hline-0.139 & -0.137 & -0.119 & -0.142 & Working capital \\
\hline$(0.025)$ & $(0.025)$ & $(0.023)$ & $(0.021)$ & \\
\hline 0.081 & 0.035 & -0.036 & -0.100 & $D^{\text {Low }} \times$ Cash flow \\
\hline$(0.034)$ & $(0.036)$ & $(0.040)$ & $(0.047)$ & \\
\hline 0.028 & 0.066 & 0.065 & 0.061 & Cash flow \\
\hline$(0.016)$ & $(0.017)$ & $(0.018)$ & $(0.017)$ & \\
\hline-0.001 & -0.066 & -0.092 & -0.071 & $D^{\text {High }} \times$ Cash flow \\
\hline$(0.02,8)$ & $(0.028)$ & $(0.031)$ & $(0.028)$ & \\
\hline 473 & 473 & 473 & 473 & \# Firms \\
\hline 4257 & 4257 & 4257 & 4257 & \# Observations \\
\hline$\chi^{2}(7)=$ & $\chi^{2}(7)=$ & $\chi^{2}(7)=$ & $\chi^{2}(7)=$ & Joint significance \\
\hline $4449.71^{* *}$ & $4401.38^{* *}$ & $4444.16^{\circ}$ & $5215.69^{* 0}$ & \\
\hline$\chi^{2}(143)=$ & $\chi^{2}(143)=$ & $x^{2}(143)=$ & $\chi^{2}(143)=$ & Sargan \\
\hline 148.18 & 155.28 & 151.18 & 156.12 & \\
\hline-1.08 & -1.01 & -1.09 & -1.07 & SOSC \\
\hline$\chi^{2}(8)=$ & $\chi^{2}(8)=$ & $\chi^{2}(8)=$ & $\chi^{2}(8)=$ & $\operatorname{DS}\left(Y_{1-2}\right)$ \\
\hline 9.10 & 10.28 & 11.12 & 9.81 & \\
\hline$x^{2}(45)=$ & $\chi^{2}(45)=$ & $x^{2}(45)=$ & $x^{2}(45)=$ & $\operatorname{DS}\left(X_{1-1}\right)$ \\
\hline 45.64 & 52.17 & 50.00 & 56.95 & \\
\hline
\end{tabular}

production over assets). Heteroscedasticity-consistent standard errors are in parentheses. sales less the log of assets; Working capital measures investment in cash, inventories and after interest and taxes, but before depreciation and dividends over assets; $D^{\text {low }}\left(D^{\text {hisht }}\right)$ is a threshold value low $\left.{ }^{\text {light }}\right)$ and 0 otherwise. ${ }^{\text {Low }}\left({ }^{\text {high }}\right)$ is defined in the column heading as a Investment and Working capital lagged two and three periods and Sales growth, Sales-assets

refers to the heteroskedasticity-consistent Sargan test for overidentifying restrictions; SOSC first differences. The Difference Sargan (DS) statistics restrict the instrument set. Defining variables), $D S\left(Y_{i-2}\right)$ excludes $Y_{1-2}$ from this set and re-assesses the overidentifying respectively. 
holdings: the drop in excess ICFS merely matches the rise in reference ICFS. In absolute terms therefore, the investment of firms with highly positive slack is still insensitive to inflows of cash.

It then remains to be explained what caused the increase in reference ICFS. This relates to the second interesting difference with the earlier discussion. Specifically, reference ICFS increases and becomes statistically significant precisely when excess ICFS for firms with very large shortfalls of liquidity drops and loses statistical significance. It thus appears that the jump in reference ICFS is triggered by an increasing transition of high-ICFS observations from the low liquidity group to the reference group. The observations with particularly high ICFS are apparently those with shortages of liquidity in the order of 50 to 70 percent. Observations with larger shortfalls of liquidity exhibit a considerably lower sensitivity of investment to cash flow. In particular, the excess ICFS for this group turns negative in column (7) and is significantly negative in column (8). In absolute terms, firms with liquidity holdings short of the target by 80 percent or more even exhibit a negative ICFS!

The results in column (8) in particular provide statistically significant support of a non-monotonic relationship between the ICFS and the deviation of observed from targeted liquidity holdings. Although these results confirm the main conclusion of KZ97 - the ICFS does not exhibit a monotonic relationship with financing constraints - they also corroborate the interpretation by Fazzari et al. (2000) that financial distress effects play a role here. Specifically, in our analysis firms for which observed liquidity holdings fall short of the target by more than 80 percent likely face serious liquidity problems: liquidity holdings are at 20 percent or less of levels deemed prudent. Similarly, in KZ97 the firms with the lowest levels of reported liquidity (and the lowest ICFS) are those that are "prevented from paying dividends and have little cash available" as well as those that are "in violation of debt covenants, have been cut out of their usual source of credit, are renegotiating debt payments, or declare that they are forced to reduce inwestment because of liquidity problems". (pp. 181-182). As Fazzari et al. (2000) point out, "[d] uring [such] years of financial distress, firms, possibly at the insistence of their creditors, are likely to use cash flow to enhance liquidity and avoid bankruptcy resulting in little change in fixed investment" (p. 702) and this is empirically reflected in a lower ICFS. This reasoning is also in line with evidence presented in previous chapters of this thesis. In chapter 6 we specifically stress the increasing probability of financial distress to motivate the incentive to make upward adjustments to liquidity holdings. Further back, in chapter 3, we show how the expectation of costly liquidation already affects the connection between finance and investment (although there we did not sort out firms that are approaching financial distress). 


\subsubsection{Sensitivity of the results}

Our results suggest that low liquidity holdings relative to target - so long as they are not so low as to threaten the continuation of the firm - associate with a stronger sensitivity of investment to inflows of cash. When liquidity falls farther short of the target the firm becomes more financially constrained - possibly approaches financial distress - but this is no longer reflected by a higher ICFS. Then, firms not only become more reluctant to use liquid assets to finance contemporary investment, but also increasingly use expected cash inflows to replenish liquidity holdings. As a result, the ICFS decreases in the shortage of liquidity and becomes uninformative as a measure of contemporary financing constraints. Our results are less ambiguous regarding surpluses of liquidity; there is no evidence that these surpluses are used to ameliorate contemporary financing constraints.

Sensitivity of these results is checked in the following way. We have excluded working capital investment from the (fixed) investment equation and find qualitatively identical results. The same results obtain when we include interaction terms on working capital investment in addition to those on cash flow. We also ran the regressions for manufacturing and services firms separately. The results are summarised in the appendix, table A7.2. In contrast with the above results, for manufacturing firms separately it appears that an excess of liquidity relative to the target goes together with a positive excess ICFS. This is evidence not readily supportive of a financing constraints explanation, but possibly reveals a free cash flow argument (Jensen, 1986), suggesting that an excess of liquid assets may be divested through the financing of pet projects for which external capital cannot be attracted. Apart from this dissonance, results for the full sample of firms are broadly similar to those obtained for the sub-sample of manufacturing firms and very similar to those obtained for services firms separately.

\subsubsection{What information is hidden in observed liquidity holdings?}

We stress once more the importance of using target deviations, instead of observed liquidity holdings, for the detection of financing constraints. To illustrate the differential informational content of liquidity holdings in this regard, we also check how different observed liquidity positions relate to the ICFS. We compare this informational content with that embodied in its components: targets and deviations. Specifically, we ran all the regressions in table 7.2 while defining the interaction dummies not on the basis of target deviations, but on the basis of observed liquidity holdings and liquidity targets, respectively. The results are summarised in panels $\mathrm{A}$ and $\mathrm{B}$ of table 7.3 and compared with our findings on target deviations, summarised in panel $\mathrm{C}$ of the table. The results in panel A demonstrate the lack of any structural relation of 


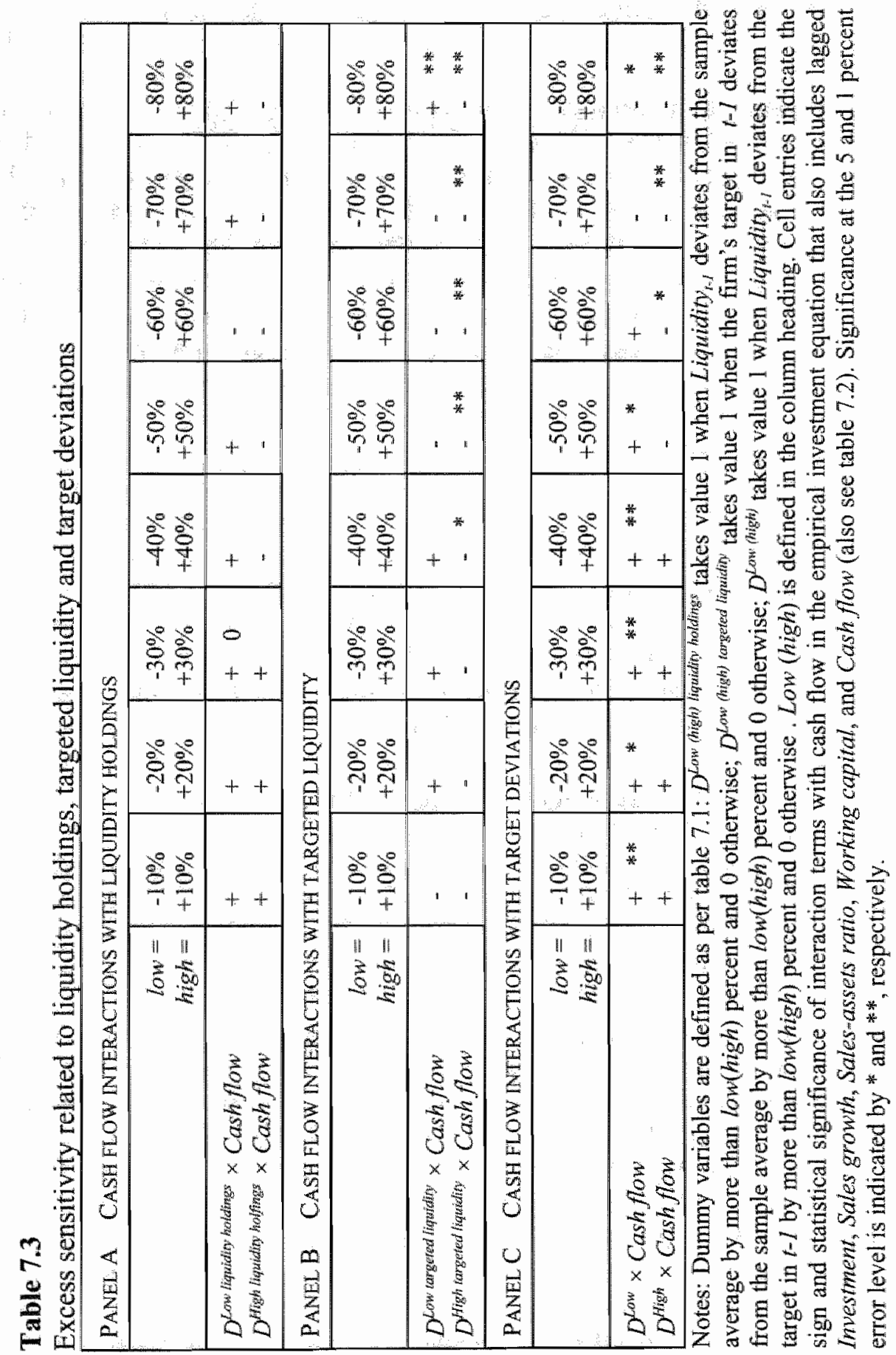


observed liquidity holdings and the ICFS. Panel B suggests some connection between liquidity targets and the ICFS. Specifically, firms that specified high targets in the past exhibit a weaker contemporary ICFS. We are hard pressed to provide an unambiguous explanation, though. On the one hand, it seems logical that more patient firms carried larger balances of precautionary liquidity from the past into the present. Hence such firms do not bear the brunt of contemporary financing constraints as much as their impatient counterparts that carry only relatively low levels of precautionary balances from the past. This is in line with the evidence in panel B. On the other hand, however, we argued that firms raise liquidity targets when they expect stricter financing constraints in the future. Using this reasoning, firms that specified high targets in the past are those that expected to be severely constrained in the present. This reasoning thus goes against the evidence in panel $B$.

An extended analysis of the connection between targeted liquidity holdings and the ICFS is interesting but also beyond the scope of this chapter. The main conclusion derived from the evidence in table 7.3 is that the deviation of observed from targeted liquidity holdings contains different information on the ICFS than do either observed liquidity holdings or targeted liquidity holdings. Hence our use of target deviations as measures of financing constraints instead of observed or reported liquidity holdings is non-trivial.

\subsection{Summary and conclusions}

Observed or reported corporate liquidity holdings are not useful measures of financing constraints. Theoretically, corporate liquidity is a means to ameliorate such constraints in a static setting, but observed liquidity holdings do not indicate the severity of the constraints. Additionally, the corporate liquidity decision plays a crucial role in the inter-temporal minimisation of the burden of financing constraints. As such, the expectation of future financing constraints provides the firm with an incentive to carry precautionary liquid balances into the future. In a dynamic setting, therefore, high levels of observed liquidity holdings may signal expectations about future financing constraints, rather than indicating an abundance of freely investable internal funds. We propose instead to use the deviations of observed from targeted liquidity holdings as useful measures of financing constraints. In doing so, we acknowledge that part of observed liquidity is reserved for the purpose of alleviating future financing constraints. Liquidity in excess of these targets is slack and therefore freely available for alleviating contemporary financing constraints.

Empirically, we use as measures of optimal, precautionary, or targeted liquidity holdings the firm-specific liquidity targets computed before in chapter 
5. We consider deviations from these targets to be freely investable funds, or slack. We estimate a simple investment model augmented with cash flow and find that variations in observed liquidity holdings do not relate to the ICFS. Interestingly, we find that the deviations do relate to the ICFS, but not in a monotonic way. Our results suggest that low liquidity holdings rellative to target - so long as they are not too low as to threaten the continuation of the firm associate with a stronger sensitivity of investment to inflows of cash. When liquidity falls farther short of the target the firm becomes more financially constrained - possibly approaches financial distress - but this is no longer reflected by a higher ICFS. Then, we argue, firms not only become more reluctant to use liquid assets to finance contemporary investment, but also increasingly intend to use expected cash inflows to replenish liquidity holdings. As a result, the ICFS decreases in the shortage of liquidity and becomes uninformative as a measure of contemporary financing constraints.

While our empirical results support those reported by KZ97 for a small sample of US firms, our conclusion does not. We find that the ICFS usually provides an accurate indication of financing constraints. The concept of financing constraints applies to the constraints that financially healthy firms firms whose continuity is not challenged - experience when they apply for external finance. In these instances we find that the ICFS relates to financing constraints monotonically. Nonmonotonicity pertains only to those instances where a firm's liquidity position is sufficiently problematic that it likely threatens the continuity of the firm. We find that this does not warrant the utter rejection of the ICFS as a measure of financing constraints. Instead, it underscores that financial distress cannot be regarded as a particularly severe financing constraint, but deserves special research attention as a separate financial status.

Lastly, we want to address why our analysis of the interaction between corporate investment and corporate liquidity holdings is still limited. While we considered in this chapter the role of liquidity holdings in the investment decision, we essentially treated the former as given. In particular, we did not allow for feedback effects running from the investment decision to a firm's liquidity holdings. To illustrate the implications thereof, consider a firm that raises its contemporary cash flow expectations (e.g., adjusts its earnings forecast upwards). We know from this chapter that the firm will expand contemporary investment and we also know from the previous two chapters that part of the additional cash flow feeds into increased liquidity holdings. What we do not know is what happens to future investment and liquidity holdings. On the one hand, increased contemporary investment outlays drain liquidity, possibly leaving the firm with a shortage of liquidity relative to target, which makes the future investment decision more sensitive to financing constraints. On the other 
hand, the cash flow that is added to liquidity holdings counters this effect and possibly pushes the firm above its target, which stimulates future investment. We simply cannot tell what happens without analysing the corporate investment and liquidity holdings truly simultaneously. We leave such an extension of the analysis as an interesting and fruitful avenue for future research. 


\section{Appendix: Excess ICFS results for manufacturing and services firms}

Table A7.1

Classifications of manufacturing and services firms based on target deviations

\begin{tabular}{|c|c|c|c|c|c|c|}
\hline & \multicolumn{2}{|c|}{$\begin{array}{c}\text { All } \\
\text { firms }\end{array}$} & \multicolumn{2}{|c|}{$\begin{array}{l}\text { Manufacturing } \\
\text { firms }\end{array}$} & \multicolumn{2}{|c|}{$\begin{array}{l}\text { Services } \\
\text { firms }\end{array}$} \\
\hline & Count & $\%$ & Count & $\%$ & Count & $\%$ \\
\hline Low $(\leq-10 \%)$ & 1786 & 42.0 & 759 & 42.8 & 690 & 42.1 \\
\hline Medium & 367 & 8.6 & 139 & 7.8 & 162 & 9.9 \\
\hline High $(\geq+10 \%)$ & 21.04 & 49.4 & 875 & 49.4 & 786 & 48.0 \\
\hline Low $(\leq-20 \%)$ & 1572 & 36.9 & 671 & 37.8 & 584 & 35.7 \\
\hline Medium & 751 & 17.7 & 280 & 15.8 & 332 & 20.2 \\
\hline $\operatorname{High}(\geq+20 \%)$ & 1934 & 45.4 & 822 & 46.4 & 722 & 44.1 \\
\hline Low $(\leq-30 \%)$ & 1346 & 31.6 & 594 & 33.5 & 488 & 29.8 \\
\hline Medium & 1138 & 26.8 & 414 & 23.4 & 487 & 29.7 \\
\hline $\operatorname{High}(\geq+30 \%)$ & 1773 & 41.6 & 765 & 43.1 & 663 & 40.5 \\
\hline Low $(\leq-40 \%)$ & 1126 & 26.5 & $5 \| 4$ & 29.0 & 399 & 24.4 \\
\hline Medium & 1495 & 35.1 & 559 & 31.5 & 628 & 38.3 \\
\hline High $(\geq+40 \%)$ & 1636 & 38.4 & 700 & 39.5 & 611 & 37.3 \\
\hline $\operatorname{Low}(\leq-50 \%)$ & 947 & 22.2 & 431 & 24.3 & 323 & 19.7 \\
\hline Medium & 1802 & 42.4 & 683 & 38.5 & 759 & 46.4 \\
\hline High $(\geq+50 \%)$ & 1508 & 35.4 & 659 & 37.2 & 556 & 33.9 \\
\hline Low $(\leq-60 \%)$ & 761 & 17.9 & 347 & 19.6 & 262 & 16.0 \\
\hline Medium & 2089 & 49.0 & 817 & 46.1 & 872 & 53.2 \\
\hline High $(\geq+60 \%)$ & 1407 & 33.1 & 609 & 34.3 & 504 & 30.8 \\
\hline Low $(\leq-70 \%)$ & 550 & 12.9 & 260 & 14.7 & 185 & 11.3 \\
\hline Medium & $241 \|$ & 56.7 & 942 & 53.1 & 987 & 60.3 \\
\hline High $(\geq+70 \%)$ & 1296 & 30.4 & 571 & 32.2 & 466 & 28.4 \\
\hline $\operatorname{Low}(\leq-80 \%)$ & 363 & 8.5 & 174 & 9.8 & 114 & 7.0 \\
\hline Medium & 2700 & 63.5 & 1060 & 59.8 & 1091 & 66.6 \\
\hline High $(\geq+80 \%)$ & 1194 & 28.0 & 539 & 30.4 & 433 & 26.4 \\
\hline
\end{tabular}

Notes: Observations are allocated to the Low (High) group when the target deviation falls short of (exceeds) the targeted level by $x$ percent or more in period $t-1$, where $x$ is given in brackets. They are allocated to the Medium group otherwise. 'Count' indicates the number of times, during the period 1989-1997, we observe a particular Low, Medium, or High liquidity position in $1-1 .{ }^{\circ} \%$ ' expresses this as the share of the 4257,1773 , and 1638 observations in the full sample of firms, the manufacturing sample, and the services sample, respectively. 


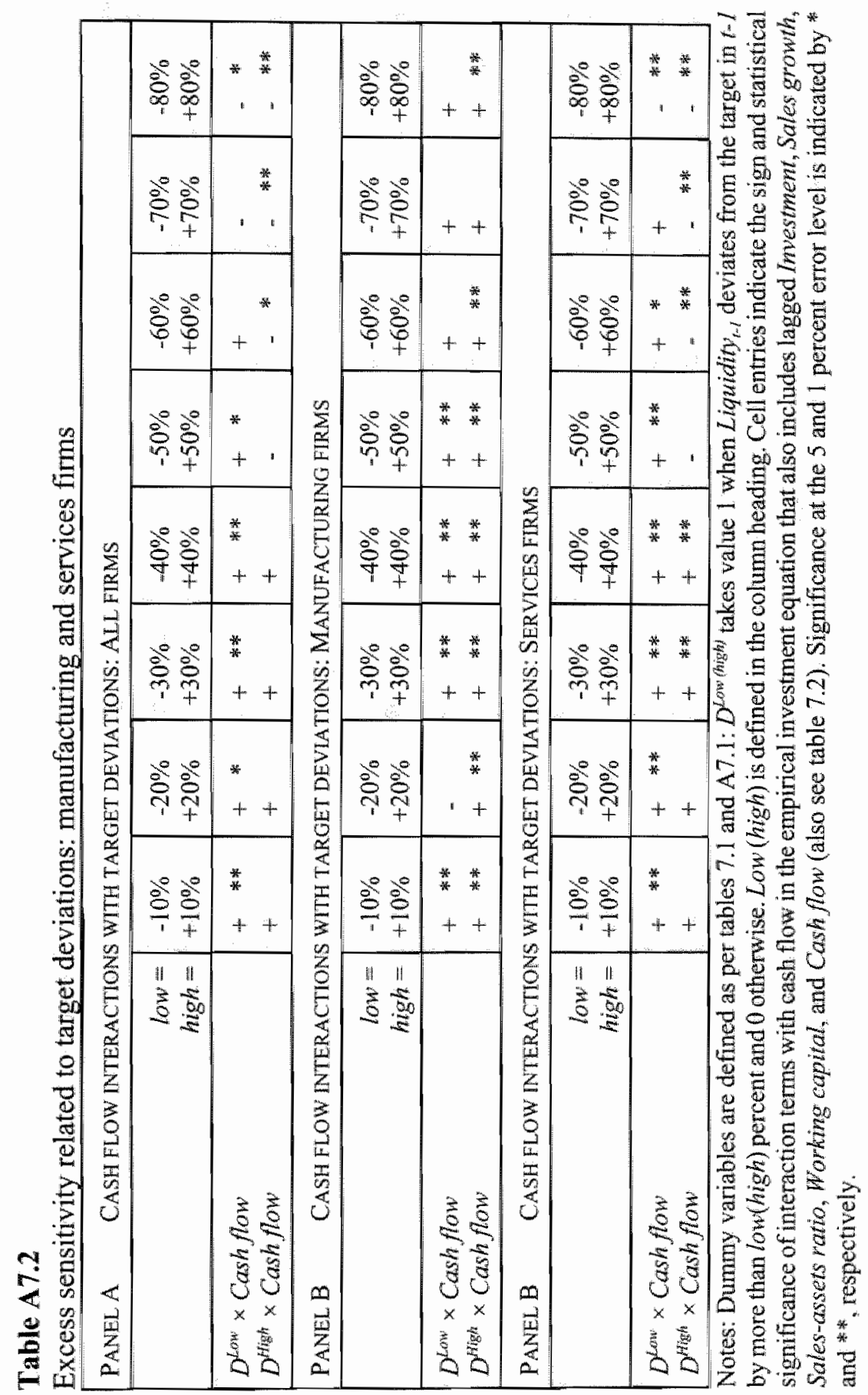




\section{Chapter 8 \\ Summary and Concluding Thoughts}

This study has developed an understanding of the determination of corporate investment and liquidity holdings when firms have information that financial markets do not have. The first main insight of this study is that informational problems make the investment and financing decisions interdependent. Firms sometimes need to change investment plans because external finance is excessively costly or rationed while internal funds have been exhausted. The second main insight pertains to the ways firms try to get around such financing constraints. They allocate funds to the most productive uses within the firm, which entails the active re-allocation of means within the multi-division firm. Additionally, they hoard liquid assets so that at least some future investments can be financed without the (prior) approval of financial markets. This closely relates to the third main insight: we cannot read the dependence of corporate investment on the accumulation of internal finance from the stock of liquid assets that the firm reports in its balance sheet. Financial slack, or "free' cash measured at the firm-level - is a much better indicator.

\subsection{Summary}

Chapter 2 provided an overview of an empirical literature on the dependence of firm-level investment on the accumulation of internal funds. The main finding that enjoys broad empirical support is that firms that we characterise as being especially vulnerable to problems of asymmetric information are also the firms for which investment depends most strongly on the accumulation of internal funds. Such firms for instance have a specific financial structure (e.g., are highly leveraged), engage in specific activities (e.g., invest heavily in R\&D activities), or lack a solid reputation in the financial markets (e.g., are young or have speculative credit ratings).

In chapter 3 we demonstrated that we cannot disconnect a firm from its environment in the analysis of interrelated investment and finance decisions. Through expected liquidation costs, namely, we argue that the relation between the firm and its environment has an important impact on the dependence of corporate investment on internal finance. A firm whose performance is procyclical with that of its industry faces more problems in selling its assets to an 
industry-peer in the event of liquidation, as most of its industry-peers also face poor performance then. Hence the firm has to resort to industry-outsiders to sell its assets and fetches a lower price. This reduces the expected liquidation value of the assets of the pro-cyclical firm, which hampers the accumulation of external funds for such a firm and hence makes its investment depend more strongly on the accumulation of internal funds. Evidence from Dutch manufacturing firms "investment behaviour in the mid-1990s supports this line of reasoning.

Costly or rationed external finance increases the importance of optimal allocation of the scarce internal funds within the firm. Within a single-division firm this implies simply that funds must be directed towards the most profitable investment opportunities. Within the multi-division firm the same principle straightforwardly suggests that sometimes the resources generated by division $B$ must be directed towards the highly profitable investment opportunities of division A. In chapter 4 we explored the extent of such inter-division reallocation of funds within Dutch conglomerates using data on divisional investment and finance that covers the second half of the 1990s. Considering the soaring stock markets and the exceptionally good economic performance during this period, external finance is probably relatively inexpensive and mostly unrationed in our sample. Nevertheless, we find evidence that firms use internal capital markets - i.e. re-allocate resources between divisions of one and the same firm - even during this period provided that the organisational structure is supportive of such internal re-allocation. Specifically, internal capital markets are used within conglomerates that have a centralised organisational structure overall as well as within those for which at least the financial organisation has a supra-divisional character.

A most uncomfortable observation in the empirical literature on investment and finance is that firms or conglomerates that we characterise as especially vulnerable to problems of asymmetric information are the same ones that oftentimes report an apparent abundance of internal funds as well. It is hard to conceive of these firms' investment plans to depend on the accumulation of internal funds when their stocks of these funds are so high. This in fact was one of the major motivations to analyse corporate liquidity holdings in Part II of this thesis.

In chapter 5 we analysed optimal holdings of internal funds in liquid form for nearly 500 large Dutch firms observed during the late 1.980 s and most of the 1990 s. We explicitly distinguished theoretically as well as empirically between the short-run and long-run determination of corporate liquidity holdings. Regarding the long-run, we developed the argument that firms demand a precautionary amount of internal funds in liquid form. The anticipation of restricted future access to external funds plays an important role in such long- 
run target levels of liquidity: firms for which external finance is expected to be most costly or most likely to be rationed hoard the largest amounts of liquid assets for precautionary reasons. Short-run liquidity determination additionally has a passive character: inflows of funds are allowed to swell liquidity holdings, while expenditures are partly funded from these liquidity holdings. Nevertheless, firms make considerable adjustments towards long-run liquidity targets even in the short run. Clearly, firms do not want to lose track of their long-run targets too much even in the short run. This strongly suggests that overly liquid firms may seem unconstrained at present, but possibly expect future restrictions in the financing of their investment that makes them behave constrained now despite apparent richness.

In chapter 6 we inspected more closely the short-run importance of adjusting liquidity holdings towards long-run target levels. "There, we argued that for profit maximising firms it is optimal to have liquidity holdings accommodate postponed adjustment in the capital stock or the capital structure, because among such key decision variables corporate liquidity is probably the least expensive variable to adjust. A strategy of keeping liquidity always 'on target' is then strictly inferior. This begs the question of when exactly the importance of liquidity adjustment predominates the firm's short-run decisions. This is an important issue because it gives an indication of how much variation in corporate liquidity holdings is 'normal' in the sense that it does not unduly affect for instance the investment decisions of the firm. We found evidence of a relatively large range of inaction around the corporate liquidity target in which the liquidity ratio may more or less freely vary without inciting efforts to adjust this ratio back to target. When liquidity has strayed too far from optimal levels, however, liquidity adjustment is predominant and short-run target adjustment efforts increase considerably.

In chapter 7 we connected the corporate investment and liquidity decisions. Specifically, there we analysed the connection between corporate liquidity holdings and the dependence of corporate investment on the accumulation of internal funds. The two important insights of this analysis are the following. First, observed holdings of internal funds in liquid form provide no information regarding the dependence of corporate investment on the accumulation of internal funds. We demonstrate this result both theoretically and empirically. Intuitively, this insight follows from the fact that corporate liquidity holdings and also the dependence of investment on finance result from a common factor: the degree of informational problems between the firm and financial markets. Hence observed corporate liquidity holdings cannot be treated as a stock of free cash, readily available for the financing of contemporary investment. 
The second main insight of chapter 7 pertains to the role of deviations of observed from targeted liquidity holdings in explaining the dependence of investment on the accumulation of internal funds. In contrast with observed liquidity holdings, deviations of contemporary from targeted liquidity holdings can be regarded as free cash. Theoretically therefore, they provide a better indication to what extent a firm depends on the accumulation of internal funds for the financing of contemporary investment. Empirical evidence supports this line of reasoning: for financially healthy firms we obtained that investment is sensitive to variations in internal funds when they have low stocks of free cash but not so when such stocks are abundant.

\subsection{Further research}

Let us conclude this study with a brief discussion of some fruitful directions for further research.

First, there is considerable scope for improving our understanding concerning the motivations for and the implications of firms' active use of internal capital markets. Specifically, we established in chapter 4 that firms with a strongly centralised organisational structure as well as those that coordinate financial affairs at the supra-divisional level are better able to re-allocate funds internally. In chapter 5 we already hinted at the differenti motives for firms to hoard precautionary liquidity when they have the option to apply internal subsidisation of investment by profitable, financially constrained divisions with funds from cash-rich divisions that are less profitable. It would be interesting to address this issue explicitly. Furthermore, while we stressed the benefits of internal capital markets from the firms' perspective, we never questioned their motives. It would be interesting to analyse whether firms that actively use internal capital markets do so with the aim of improving financial efficiency, or to keep external capital markets at arm's length (creating intriguing problems of corporate control in the process). One way to make this distinction is to check whether firms use the internal capital market to over-invest in relatively poor performing divisions and vice versa. Another approach is to collect direct observations on managements' motivations using a survey questionnaire.

Second, there is considerable need for further analysis of the structural determinants of firm-level liquidity holdings. On the one hand, more direct observation of the firm-specific problems of asymmetric information is highly desirable. A connection of firm-level financial information with more detailed information on for instance credit ratings, bank relationships, credit lines, and ownership structure is particularly informative in this regard. On the other hand, the analysis needs extension to new data sets, covering different countries and 
different financial systems. This facilitates a distinction between, say, 'general' determinants of corporate liquidity holdings and those that are specific to a sample, country, or financial system.

Related to this is the need to demonstrate more directly the relevance of firm-level analysis of corporate liquidity demand. We argued in chapter 5 that aggregation bias most likely explains why individually, firms adjust so swiftly to their firm-level liquidity targets while we observe very slow adjustment for the corporate sector as a whole. Using our measures of firm-level liquidity targets, we can construct an indicator of target-dispersion to capture the heterogeneity of firms in setting liquidity targets. The relevance of aggregation bias in the analysis of corporate liquidity demand implies that this dispersion indicator should relate negatively to the observed speed of adjustment in aggregate corporate liquidity demand.

Last but not least, this study demonstrates that corporate investment expenditures have an impact on liquidity holdings (chapters 5 and 6), while the latter to a significant extent determine how financially constrained the firm behaves in its investment decisions (chapter 7). Hence there is a strong suggestion that further research should focus on the integrated analysis of corporate liquidity holdings and corporate investment decisions. 


\section{References}

Abel, A. B., and J. C. Eberly (1994), "A Unified Model of Investment Under Uncertainty," American Economic Review, vol. 84, pp. 1369-1384.

Abel, A. B., and J. C. Eberly (1996), "Optimal Investment with Costly Reversibility," Review of Economic Studies, vol. 63, pp. 581-593.

Abel, A. B., Dixit, A. K., Eberly, J. C., and R. S. Pindyck (1996), "Options, the

Value of Capital, and Investment," Quarterly Journal of Economics, vol. 111 ,pp. 753-777.

Arellano, M., and S. R. Bond (1991), "Some Tests of Specification for Panel Data: Monte Carlo Evidence and an Application to Employment Equations," Review of Economic Studies, vol. 58, pp. 277-297.

Arellano, M., and S. R. Bond (1998), "Dynamic Panell Data Estimation Using DPD98 for Gauss: A Guide for Users," Institute for Fiscal Studies Working Paper, no. 88/15.

Audretsch, D. B., and J. A. Elston (2002), "Does Firm Size Matter? Evidence on the Impacts of Liquidity Constraints on Firm Investment Behavior in Germany," International Journal of Industrial Organization, vol. 20, pp. $1-17$.

Baltagi, B. H., and C. Kao (2000), "Nonstationary Panels, Cointegration in Panels and Dynamic Panels: A Survey," In: B. D. Baltagi (ed.), Nonstationary Panels, Panel Cointegration, and Dynamic Panels; Advances in Econometrics, vol. 15, New York: Elsevier Science, pp. 7-51. Banerjee, A. (1999), "Panel Data Unit Roots and Cointegration: An Overview," Special Issue of the Oxford Bulletin of Economics and Statistics, vol. 61, pp. 607-629.

Barran; F., and M. Peeters (1998), "Internal Finance and Corporate Investment: Belgian Evidence with Panel Data," Economic Modelling, vol. 15, pp. 6789.

Blinder, A. (1988), "Comment on: Financing Constraints and Corporate Investment, by S. M. Fazzari, R. G. Hubbard, and B. G. Petersen," Brookings Papers on Economic Activity, pp. 196-200.

Bolton, P., and X. Freixas (2000), "Equity, Bonds, and Bank Debt: Capital Structure and Financial Market Equilibrium under Asymmetric Information," Journal of Political Economy, vol. 108, pp. 324-351. 
Bond, S. R., and C. Meghir (1994), "Dynamic Investment Models and the Firm's Financial Policy," Review of Economic Studies, vol. 61, pp. 197. 222.

Bond, S. R., and J. Van Reenen (1999), Microeconometric Models of Investment and Employment, manuscript, Institute for Fiscal Studies, London.

Boot, A. W. A. (2000), "Relationship Banking: What Do We Know?" Journal of Financial Intermediation, vol. 9, pp. 7-25.

Boot, A. W. A., and P. A. Verheyen (1997), Financiering en Macht: van Financiele Structuur tot Beheersstructuur, Deventer: Klluwer BedrijfsInformatie.

Bratkowski, A., Grosfeld, I., and J. Rostowski (2000), "Investment and Finance in De Novo Private Firms: Empirical Results from the Czech Republic, Huingary and Poland," Economics of Transition, vol. 8, pp. 101-116.

Brealey, A., and S. C. Myers (1996), Principles of Corporate Finance, New York: McGraw Hill Book Co.

Brennan, M. J., and E. S. Schwartz (1985), "Evaluating Natural Resource Investments," Journal of Business, vol. 58, pp. 135-157.

Budina, N., Garretsen, H., and E. de Jong (2000), "Liquidity Constraints and Investment in Transition Economies," Economics of Transition, vol. 8, pp. 453-475.

Caballero, R. J., Engel, E. M. R. A., and J. C. Haltiwanger (1995), "Plant-Level Adjustment and Aggregate Investment Dynamics," Brookings Papers on Economic Activity, pp. 1-39.

Calomiris, C. W., Himmelberg, C. P., and P. Wachtel (1995), "Commercial Paper, Corporate Finance and the Business Cycle: A Microeconomic Perspective," Carnegie Rochester Conference Series on Public Policy, vol. 40, pp. 203-250.

Calomiris, C. W., and R. G. Hubbard (1995), "Internal Finance and Investment: Evidence from the Undistributed Profits Tax of 1936-37," Journal of Business, vol. 68 , pp. 443-482.

Carpenter, R. E., Fazzari, S. M., and B. C. Petersen (1994), "Inventory Investment, Internal-Finance Fluctuations, and the Business Cycle," Brookings Papers on Economic Activity, pp. 75-122.

Carr, J., and M. R. Darby (1981), "The Role of Money Supply Shocks in the Short-Run Demand for Money," Joumal of Monetary Economics, vol. 8, pp. 183-199.

Chirinko, R. S. (1987), "Intertemporal Constraints, Shadow Prices, and Financial Asset Values," National Bureau of Economic Research (NBER) Working Paper Series, no. 2247. 
Chirinko, R. S. (1993), "Business Fixed Investment Spending: Modelling Strategies, Empirical Results and Policy Implications," Journal of Economic Literature, vol. 31, pp. 1875-1911.

Chirinko, R. S. (1997), "Finance Constraints, Liquidity, and Investment Spending: Theoretical Restrictions and International Evidence," Journal of the Japanese and International Economies, vol. 11, pp. 185-207.

Chirinko, R. S., Fazzari, S. M., and A. P. Meyer (1999), "How Responsive is Business Capital Formation to its User Cost? An Exploration with Micro Data," Journal of Public Economics, vol. 74, pp. 53-80.

Chirinko, R. S., and H. Schaller (1995), "Why Does Liquidity Matter in Investment Equations," Journal of Money, Credit, and Banking, vol. 27, pp. 527-548.

Cleary, S. (1999), "The Relationship between Firm Investment and Financial Status," Journal of Finance, vol. 54, pp. 673-692.

Cleary, S. (2000), "The Sensitivity of Canadian Corporate Investment to Liquidity," Canadian Journal of Administrative Sciences, vol. 17, pp. 217232.

Dasgupta, S., and K. Sengupta (2001), Financial Constraints, the Option to Invest, and Corporate Cash Balances, Hong Kong University of Science and Technology Working Paper.

DeAngelo, H., DeAngelo, L., and K. H. Wruck (2002), "Asset Liquidity, Debt Covenants, and Managerial Discretion in Financial Distress: the Collapse of L.A. Gear," Journal of Financial Economics, vol. 64, pp. 3-34.

Devereux, M., and F. Schiantarelli (1990), "Investment, Financial Factors, and Cash Flow: Evidence from UK Panel Data," in: R. G. Hubbard (ed.), Asymmetric Information, Corporate Finance and Investment, Chicago: University of Chicago Press, pp. 279-306.

Diamond, D. W. (1984), "Financiall Intermediation and Delegated Monitoring," Review of Economic Studies, vol. 51, pp. 393-414.

Diamond, D. W. (1991a), "Debt Maturity Structure and Liquidity Risk," Quarterly Journal of Economics, vol. 56, pp. 709-737.

Diamond, D. W. (1991b), "Monitoring and Reputation: The Choice Between Bank Loans and Directly Placed Debt," Journal of Political Economy, vol. 99, pp. 689-721.

Dittmar, A., Mahrt-Smith, J., and H. Servaes (2003), "International Corporate Governance and Corporate Liquidity," Journal of Financial and Quantitative Analysis, vol. 38, forthcoming.

Dixit, A. K., and R. S. Pindyck (1994), Investment Under Uncertainty, Princeton: Princeton University Press.

Donaldson, G. (1961), Corporate Debt Capacity, Cambridge, MA: Harvard University. 
Edwards, J., and K. Fischer (1994), Banks, Finance and Investment in Germany, Cambridge, New York and Melboume: Cambridge University Press.

Ees, H. van, and H. Garretsen (1994), "Liquidity and Business Investment: Evidence from Dutch Panel Data," Journal of Macroeconomics, vol. 16, pp. 613-627.

Ees, H. van, Garretsen, H., Haan, L. de, and E. Sterken (1998), "Investment and Debt Constraints: Evidence from Dutch Panel Data," in: S. Brakman, H: van Ees and S. K. Kuipers (eds.), Market Behaviour and Macroeconomic Modelling, London: Macmillan Press, pp. 159-179.

Ees; H. van, Kuper, G. H., and E. Sterken (1997), "Investment, Finance and the Business Cycle: Evidence from the Dutch Manufacturing Sector," Cambridge Journal of Economics, vol. 21, pp. 395-407.

Elston, J. A. (1996), "Dividend Policy and Investment: Theory and Evidence from US Panel Data," Managerial and Decision Economics, vol. 17, pp. $267-275$.

Elston, J. A. (1998), "Investment, Liquidity Constraints, and Bank Relationships: Evidence from German Manufacturing Firms," in: S. W. Black, and M. Moersch (eds), Competition and Convergence in Financial Markets: The German and Anglo-American Models; Advances in Finance, Investment and Banking, vol. 5, Amsterdam, New York and Tokyo: Elsevier Science, North-Holland, pp. 135-150.

Elston, J. A., and H. Horst (1995), "Bank Affiliations and Firm Capital Investment in Germany," Ifo-Studien, vol. 41, pp. 3-16.

Fazzari, S. M., Hubbard, R. G., and B. C. Petersen (1988), "Financing Constraints and Corporate Investment," Brookings Papers on Economic Activity, pp. 141-195.

Fazzari, S. M., Hubbard, R. G., and B. C. Petersen (1996), "Financing Constraints and Corporate Investment: Response to Kaplan and Zingales," National Bureau of Economic Research (NBER) Working Paper Series, no. 5462.

Fazzari, S. M., Hubbard, R. G., and B. C. Petersen (2000), "Investment-Cash flow Sensitivities Are Useful: A Comment on Kaplan and Zingales," Quarterly Joumal of Economics, vol. 125, pp. 695-705.

Fazzari, S. M., and B. C. Petersen (1993), "Working Capital and Fixed Investment: New Evidence on Finance Constraints," RAND Journal of Economics, vol. 24, pp. 328-342.

Freixas, X., and J.-C. Rochet (1997), The Microeconomics of Banking, Cambridge, MA: The MIT Press.

Galeotti, M., Schiantarelli, F., and F. Jaramillo (1994), "Investment Decisions and the Role of Debt, Liquid Assets and Cash Flow: Evidence from Italian Panel Data," Applied Financial Economics, vol. 4, pp. 121-132. 
Gilchrist, S., and C. P. Himmelberg (1995), "Evidence on the Role of Cash Flow in Reduced-Form Investment Equations," Jounal of Monetary Economics, vol. 36, pp. 541-572.

Gilchrist, S., and C. P. Himmelberg (1998), "Investment, Fundamentals and Finance," National Bureau of Economic Research (NBER) Working Paper Series, no. 6652.

Goldfeld, S. M., and D. E. Sichel (1990), "The Demand for Money," in: B. M. Friedman en F. H. Hahn (eds.), Handbook of Monetary Economics, Volume I, Amsterdam: North-Holland, pp. 299-356.

Grossman, S. J., and O. D. Hart (1983), "An Analysis of the Principal-Agent Problem," Econometrica, vol. 51, pp. 7-45.

Guiso, L., and G. Parigi (1999), "Investment and Demand Uncertainty," Quarterly Journal of Economics, vol. 114, pp. 185-227.

Haan, L. de (1997), Financial Behaviour of the Dutch Corporate Sector, Amsterdam: Thela Thesis.

Haan, L. de, Koedijk, C. G., and J. E. J. de Vrijer (1992), "De Stijging van het Liquiditeitsbezit in de Jaren Tachtig: Een Enquête onder Nederlandse Bedrijven en Financiële Instellingen," De Nederlandsche Bank Monetaire Monografieën, vol. 12.

Haan, L. de, Koedijk, C. G., and J. E. J. de Vrijer (1994), "Buffer Stock Money and Pecking Order Financing: Results from an Interview Study Among Dutch Firms," De Economist, vol. 142, pp. 287-305.

Hadlock, C. J. (1998), "Ownership, Liquidity, and Investment," RAND Journal of Economics, vol. 29, pp. 487-508.

Hamermesh, D. S., and G. A. Pfann (1996); "Adjustment Costs in Factor Demand," Journal of Economic Literature, vol. 34, pp. 1264-1292.

Harris, M., and A. Raviv (1991), "The Theory of Capital Structure," Journal of Finance, vol. 46, pp. 297-355.

Harris, J. R., Schiantarelli, F., and M. G. Siregar (1994), "The Effect of Financial Liberalization on the Capital Structure and Investment Decisions of Indonesian Manufacturing Establishments," The World Bank Economic Review, vol. 8, pp. 17-47.

Harris, R. D. F., and E. Tzavalis (1999), "Inference for Unit Roots in Dynamic Panels Where the Time Dimension is Fixed," Journal of Econometrics, vol. 91, pp. 201-226.

Hart, O. (1995), Firms, Contracts, and Financial Structure, Oxford: Clarendon Press.

Hart, O., and J. Moore (1995), "Debt and Seniority: An Analysis of the Role of Hard Claims in Constraining Management," American Economic Review, vol. 85 , pp. 567-585. 
Hayashi, F. (1982), "Tobin"s Average Q and Marginal Q: A Neoclassical Interpretation," Econometrica, vol. 50, pp. 213-224.

Hege, U., and P. Mella-Barral (2000), "Bargaining Power and Optimal Leverage," Finance, vol. 21, pp. 85-101.

Himmelberg, C. P., and B. C. Petersen (1994), "R\&D and Internal Finance: A Panel Study of Small Firms in High-Tech Industries," Review of Economics and Statistics, vol. 76 , pp. 38-51.

Holmström, B., and J. Tírole (1997), "Financial Intermediation, Loanable Funds, and the Real Sector," Quarterly Journal of Economics, vol. 112, pp. 663-691.

Holmström, B., and J. Tirole (1998), "Private and Public Supply of Liquidity," Journal of Political Economy, vol. 106, pp 1-40.

Holmström, B., and J. Tirole (2000), "Liquidity and Risk Management," Journal of Money, Credit, and Banking, vol. 32, pp 295-319.

Holmström, B., and J. Tirole (2001), "LAPM: A Liquidity-Based Asset Pricing Model," Journal of Finance, vol. 56, pp. 1837-1867.

Holtz-Eakin, D., Joulfaian, D., and H. S. Rosen (1994a), "Sticking It Out: Entrepreneurial Survival and Liquidity Constraints," Journal of Political Economy, vol. 1102 , pp. 53-75.

Holtz-Eakin, D., Joulfaian, D., and H. S. Rosen (1994b), "Entrepreneurial Decisions and Liquidity Constraints," RAND Journal of Economics, vol. 25, pp. 334-347.

Hoshi, T., Kashyap, A. K, and D. S. Scharfstein (1991), "Corporate Structure, Liquidity, and Investment: Evidence from Japanese Panel Data," Quarterly Journal of Economics, vol. 106, pp. 33-60.

Hsiao, C., and A. K. Tahmiscioglu (1997), "A Panel Analysis of Liquidity Constraints and Firm Investments," Joumal of the American Statistical Association, vol. 92, pp. 455-465.

Hu, X., and F. Schiantarelli (1998), "Investment and Capital Market Imperfections: A Switching Regression Approach Using U.S. Firm Level Panel Data," Review of Economics and Statistics, vol. 80, pp. 466-479.

Hubbard, R. G. (1998), "Capital-Market Imperfections and Investment," Joumal of Economic Literature, vol. 36, pp. 198-225.

Hubbard, R. G., and A. K. Kashyap (1992), "Internal Net Worth and the Investment Process: An Application to US Agriculture," Joumal of Political Economy, vol. 100, pp. 506-534.

Hubbard, R. G., Kashyap, A. K., and T. M. Whited (1995), "Internal Finance and Firm Investment," Journal of Money, Credit, and Banking," vol. 27, pp. 683-701.

Irelland, J., and S. Wren-Lewis (1992), "Buffer Stock Money and the Company Sector," Oxford Economic Papers, vol. 44, pp. 209-231. 
Jaramillo, F., Schiantarelli, F., and A Weiss (1996) "Capital Market Imperfections Before and After Financial Liberalization: An Euler Equation Approach to Panel Data for Equadorian Firms," Journal of Development Economics, vol. 51, pp. 367-386.

Jensen, M. C. (1986), "Agency Costs of Free Cash Flow, Corporate Finance, and Takeovers," American Economic Review, vol. 76, pp. 323-329.

Kaplan, S. N., and L. Zingales (1997), "Do Investment-Cash Flow Sensitivities

Provide Useful Measures of Financing Constraints?," Quarterly Joumal of

Economics, vol. 122, pp. 169-215.

Kaplan, S. N., and L. Zingales (2000), "Investment-Cash Flow Sensitivities Are

Not Valid Measures of Financing Constraints," Quarterly Journal of Economics, vol. 125 , pp. 707-712.

Kim, C.-S., Mauer, D. C., and A. E. Sherman (1998), "The Determinants of Corporate Liquidity: Theory and Evidence," Journal of Financial and Quantitative Analysis, vol 33, pp. 335-359.

Knoop, H. S. van der, and F. C. Hooijmans (1985), "De Evenwichtigheid van de Huidige Liquiditeitsquote," Maandschrift Economie, vol. 49, pp. 389-409. Kuipers, S. K., and B. Boertje (1988), "On the Causes of the Rise in the Liquidity Ratio in the Netherlands During the Early Eighties;" De Economist, vol. 136, pp. 50-90.

Lamont, O. (1997), "Cash flow and Investment: Evidence from Internal Capital Markets," Journal of Finance, vol. 52, pp. 83-109.

Macey, J.R, and G. P. Miller (1997), "Universal Banks are not the Answer to America's Corporate Governance "Problem": a Look at Germany, Japan, and the US," Journal of Applied Corporate Finance, vol. 9, pp. 57-73.

Mahul, O. (2000), "The Output Decision of a Risk-Neutral Producer under Risk. of Liquidation," American Journal of Agricultural Economics, vol. 82, pp. 49-58.

Matsusaka, J. G., and V. Nanda (2002), "Internal Capital Markets and Corporate Refocusing," Journal of Financial Intermediation, vol. 11, pp. 176-211.

Mella-Barral, P. (1999), "The Dynamics of Debt and Debt Reorganization," Review of Financial Studies, vol. 12, pp. 535-578.

Meyer, J., and E. Kuh (1957), The Investment Decision, Cambridge, MA: Harvard University Press.

Milne, A., and D. Robertson (1996), "Firm Behaviour under the Threat of Liquidation," Journal of Economic Dynamics and Control, vol. 20, pp. 1427-1449.

Modigliani, F., and M. H. Miller (1958), "The Cost of Capital, Corporate Finance and the Theory of Investment," American Economic Review, vol. 49 , pp. $665-669$. 
Morellec, E. (2001), "Asset Liquidity, Capital Structure, and Secured Debt," Journal of Financial Economics, vol. 61, pp. 173-206.

Myers, S. C., and N. Majluf (1984), "Corporate Financing and Investment Decisions When Firms Have Information That Investors Do Not Have," Journal of Financial Economics, vol. 13, pp. 187-221.

Myers, S. C., and R. G. Rajan (1998), "The Paradox of Liquidity," Quarterly Joumal of Economics, vol. 63 , pp. 733-771.

Oliner, S. D., and G. D. Rudebusch (1992), "Sources of the Financing Hierarchy for Business lnvestment," Review of Economics and Statistics, vol. 74, pp. 643-654.

Opler, T., Pinkowitz, L., Stulz, R. M., and R. Williamson (1999), "The Determinants and Implications of Corporate Cash Holdings," Journal of Financial Economics, vol. 52, pp. 3-46.

Opler, T., and S. Titman (1994), "Financial Distress and Corporate Performance," Journal of Finance, vol, 49, pp. 1015-1040.

Ozkan, A., and N. Ozkan (2002), Corporate Cash Holdings: An Empirical Investigation of UK Companies, University of York Working Paper.

Peyer, U. C., and A. Shivdasani (2001), "Leverage and Internal Capital Markets: Evidence from Leveraged Recapitalizations," Journal of Financial Economics, vol. 59, pp. 477-515.

Pindyck, R. S. (1991), "Irreversibility, Uncertainty, and Investment," Joumal of Economic Literature, vol. 29, pp. 1110-1148.

Pinkowitz, L., and R. Williamson (2001), "Bank Power and Cash Holdings: Evidence from Japan," Review of Financial Studies, vol. 14, pp. 10591082.

Saidenberg, M. R., and P. E. Strahan (1999), "Are Banks Still Important for Financing Large Businesses?" Federal Reserve Bank of New York Current Issues in Economics and Finance, vol. 5.

Scaramozzino, P. (1997), "Investment Irreversibility and Finance Constraints," Oxford Bulletin of Economics and Statistics, vol. 59, pp. 89-108.

Schaller, H. (1993), "Asymmetric Information, Liquidity Constraints, and the Canadian Investment," Canadian Journal of Economics, vol. 26, pp. 552574.

Scharfstein, D. S., and J. C. Stein (2000), "The Dark Side of Internal Capital Markets: Divisional Rent-Seeking and Inefficient Investment," Journal of Finance, vol. 55, pp. 2537-2564.

Schiantarelli, F. (1996), "Financial Constraints and Investment: Methodological Issues and International Evidence," Oxford Review of Economic Policy, vol. 12 , pp. $70-89$. 
Schiantarelli, F., and A. Sembenelli (2000), "Form of Ownership and Financial Constraints: Panel Data Evidence From Flow of Funds and Investment Equations," Empirica, vol. 27, pp. 175-192.

Schnure, C. (1997), "Internal Capital Markets and Investment: Do the Cash Flow Constraints Really Bind?" Board of Governors of the Federal Reserve System, Finance and Economics Discussion Series, no. $1997 / 39$.

Shin, H.-H., and Y. S. Park (1999), "Financing Constraints and Internal Capital Markets: Evidence from Korean 'Chaebols'," Journal of Corporate Finance, vol. 5, pp. 169-191.

Shin, H.-H., and R. M. Stulz (1998), "Are Internal Capital Markets Efficient?" Quarterly Journal of Economics, vol. 113, pp. 531-552.

Shleifer, A., and R. Vishny (1992), "Liquidation Values and Debt Capacity: A Market Equilibrium Approach," Journat of Finance, vol: 47, pp. 13431366.

Shyam-Sunder, L., and S. C. Myers (1999), "Testing Static Tradeoff Against Pecking Order Models of Capital Structure," Journal of Financial Economics, vol. 51, pp. 219-244.

Stein, J. C. (1997), "Internal Capital Markets and the Competition for Corporate Resources," Journal of Finance, vol. 52, pp. 111-133.

Stein, J. C. (1998), "The Dark Side of Internal Capital Markets II: Evidence from Diversified Conglomerates," National Bureau of Economic Research (NBER) Working Paper Series, no. 6352.

Stiglitz, J. E. (1992), "Capital Markets and Economic Fluctuations in Capitalist Economies," European Economic Review, vol. 36, pp. 269-306.

Stiglitz, J. E., and A. Weiss (1981), "Credit Rationing in Markets with Imperfect Information," American Economic Review, vol. 71, pp. 393-410.

Summers, L. H. (1981), "Taxation and Corporate Investment - A Q-Theory

Approach," Brookings Papers on Economic Activity, pp. 67-140.

Swamy, P. A. V. B., Tinsley, P. A., and G. R. Moore (1982), "An Autopsy of a Conventional Macroeconomic Relation: The Case of Money Demand," Federal Reserve Board of Washington (DC) Special Studies Paper, no. 167.

Tobin, J. (1969), "A General Equilibrium Approach to Monetary Policy," Journal of Money, Credit, and Banking, vol. 1, pp. 15-29.

Trigeorgis, L. (1996), Real Options: Managerial Flexibility and Strategy in Resource Allocation, Cambridge, MA and London: MIT Press.

Vogt, S. C. (1994), "The Role of Internal Financial Sources in Firm Financing and Investment Decisions," Review of Financial Economics, vol. 4, pp. 124. 
Weigand, J., and D. B. Audretsch (1999), "Does Science Make a Difference? Investment, Finance and Corporate Governance in German Industries," Centre for Economic Policy Research (CEPR) Working Paper, no. 2056.

Weiss, L. A., and K. H. Wruck (1998), "Information Problems, Conflicts of Interest, and Asset Stripping: Chapter 11's Failure in the Case of Eastern Airlines," Journal of Financial Economics, vol. 48, pp. 55-97.

White, H. (1982), "Instrumental Variables Regression with Independent Observations," Econometrica, vol. 50, pp. 483-499.

Whited, T. M. (1992), "Debt, Liquidity Constraints, and Corporate Investment: Evidence from Panel Data," Journal of Finance, vol. 47, pp. 1425-1470.

Whited, T. M. (2001), "Is It Inefficient Investment that Causes the Diversification Discount?" Journal of Finance, vol. 56, pp. 1667-1691.

Wit, B. de, and R. Meyer (1998), Strategy, Process, Content and Context, London: International Thomson Business Press.

Worthington, P. R. (1995), "Investment, Cash Flow, and Sunk Costs;" Journal of Industrial Economics, vol. 43, pp. 49-61. 


\section{Samenvatting (Summary in Dutch)}

\section{Belangrijkste inzichten}

Deze studie heeft als doel om de investeringsbeslissing van een onderneming meer inzichtelijk te maken in een omgeving waarin informatie asymmetrisch is verdeeld tussen de onderneming en haar externe vermogensverschaffers. Over het algemeen beschikt de onderneming over meer informatie omtrent de kansen en bedreigingen die haar verwachte winstgevendheid beïnloeden. Asymmetrische informatie vormt een probleem in de relatie tussen de onderneming en haar externe vermogensverschaffers wanneer de onderneming dit informatievoordeel zou kunnen uitbuiten.

Het eerste belangrijke inzicht dat uit deze studie voortvloeit is dat door problemen van asymmetrische informatie een afhankelijkheid ontstaat tussen de investerings-en financieringsbeslissing van de onderneming. De ondememing ziet zich soms genoodzaakt haar investeringsplannen te herzien, hoewel er voldoende winstgevende investeringsmogelijkheden voorhanden zijn. De eigen middelen zijn dan ontoereikend om de investeringsplannen te realiseren, terwijl extern vermogen niet beschikbaar is of te hoog geprijsd. De onderneming kan dan pas weer investeren wanneer het eigen middelen weet te genereren, ofwel voldoende winst maakt.

Ondernemingen trachten dergelijke financieringsrestricties zoveel mogelijk te verlichten, Allereerst dirigeren zij de beschikbare middelen intern naar de meest rendabele investeringsprojecten. Binnen een uit meerdere divisies bestaande onderneming impliceert dit een actieve herverdeling van schaarse ondernemingsmiddelen tussen de verschillende divisies. Daarnaast potten ondernemingen een deel van hun interne middelen in liquide vorm op. Zo kan ten minste een gedeelte van de toekomstige investeringen worden gefinancierd zonder goedkeuring (vooraf) van externe vermogenswerschaffers.

Het uit voorzorg oppotten van liquide middelen heeft een belangrijke implicatie: de grootte van de balanspost liquide middelen is geen goede graadmeter van de mate waarin investeringen afhangen van de ondernemingswinsten. 'Rijke', financieel onafhankelijke ondernemingen zijn niet noodzakelijkerwijs de ondernemingen met grote hoeveelheden kasmiddelen, maar heel specifiek die ondernemingen die zich kunnen 
veroorloven een gedeelte van deze middelen per direct aan te wenden voor de financiering van nieuwe investeringen.

\section{Korte samenvatting per hoofdstuk}

$\mathrm{Na}$ een korte algemene inleiding in hoofdstuk 1 geeft hoofdstuk 2 een overzicht van de empirische literatuur die verklaringen zoekt voor de gevoeligheid van ondernemingsinvesteringen voor ondernemingswinsten. In dit hoofdstuk wordt brede empirische ondersteuning gevonden voor de bevinding dat met name de ondernemingen die we kunnen bestempelen als bijzonder gevoelig voor problemen van asymmetrische informatie de ondernemingen zijn die in dezen een zeer sterke gevoeligheid laten zien. Zulke ondernemingen worden gekenmerkt door een bepaalde financiële structuur (bijvoorbeeld een zware schuldenlast), houden zich bezig met bepaalde activiteiten (doen grote investeringen in R\&D activiteiten), of het ontbreekt ze aan een degelijke reputatie in de financiële markten (ze zijn jong of krijgen slechte kredietrisico's toegewezen).

In hoofdstuk 3 wordt aangetoond dat een onderneming niet los kan worden gezien van haar omgeving wanneer we het onderlinge verband tussen investeren en financieren onderzoeken. Via verwachtte liquidatiekosten stelt dit hoofdstuk namelijk dat de relatie tussen de onderneming en haar omgeving een belangrijke invloed uitoefent op dit onderlinge verband. Zo zal bijvoorbeeld een cyclisch presterende onderneming meer moeite hebben haar inboedel aan branchegenoten te verkopen in het geval van liquidatie, aangezien de meesten van hen juist dan ook zelf niet al te best presteren. Zo'n onderneming zal zich derhalve tot niet-branchegenoten moeten richten, hetgeen haar vooraf verwachtte liquidatiewaarde verlaagt. Dit bemoeilijkt het aantrekken van externe financiering en maakt de investeringen van de cyclische onderneming meer gevoelig voor fluctuaties in interne middelen. Het investeringsgedrag van Nederlandse industriële ondernemingen in de jaren negentig ondersteunt deze gedachte.

Dure of gerantsoeneerde externe middelen vergroten het belang voor de onderneming on de beschikbare schaarse middellen intern een zo efficiënt mogelijke bestemming te geven. Binnen een onderneming bestaand uit één enkele divisie betekent dit simpelweg dat middelen naar de meest rendabele investeringsprojecten moeten vloeien. Binnen de uit meerdere divisies bestaande onderneming suggereert hetzelfde principe dat middelen optimaal moeten worden herverdeeld tussen de verschillende divisies van één en dezelfde onderneming. De middelen die divisie $\mathrm{B}$ genereert kunnen dan bijvoorbeeld naar de bijzonder winstgevende investeringsprojecten van divisie A vloeien. In 
hoofdstuk 4 wordt de mate van dergelijke transfers van middelen tussen divisies van dezelfde ondernemingen onderzocht. We analyseren hiertoe investeringsuitgaven en financiering van divisies van Nederlandse conglomeraten in de tweede helft van de jaren negentig. Gelet op het uitermate ondernemingsvriendelijke beursklimaat en de zeer goede algemeen economische ontwikkeling gedurende deze periode, is het aannemelijk dat externe financiering relatief goedkoop en meestal ongerantsoeneerd was. Desondanks vinden we zelfs gedurende deze periode bewijs voor actief gebruik van interne kapitaalmarkten - dat wil zeggen actieve herverdeling van middelen tussen verschillende divisies van dezelfde onderneming - als er ten minste een ondersteunende organisatiestructuur aanwezig is. Meer in het bijzonder, interne kapitaalmarkten worden gebruikt binnen ondernemingen die sterk centraal georganiseerd zijn alsmede ondernemingen die ten minste de financiële organisatie boven de divisies hebben geplaatst.

De economische literatuur kan derhalve middels fricties in de uitwisseling van informatie tussen ondernemingen en kapitaalmarkten verklaren waarom investeringen afhankelijk zijn van veranderingen in interne middelen. Een belangrijke kanttekening die hierbij moet worden geplaatst, is dat de ondernemingen die het meest onderhavig zijn aan dergelijke informatieproblemen vaak ook ogenschijnlijke overvloeden aan (liquide) interne middelen blijken te bezitten. Het is moeilijk voorstelbaar dat de investeringsplannen van deze ondernemingen afhankelijk zijn van de aanwas van interne middelen wanneer deze middelen zo rijkelijk voor handen lijken te zijn. Dit vormt een belangrijke motivatie voor de analyse van het houderschap van liquide middelen door ondernemingen in deel II van deze studie.

In hoofdstuk 5 staat daarom het optimaal houderschap van interne middelen in liquide vorm centraal voor zo'n 500 grote, Nederlandse ondernemingen aan het eind van de jaren tachtig en gedurende het grootste gedeelte van de jaren negentig. Zowel theoretisch als empirisch onderscheiden we korte en lange termijn argumenten die dit houderschap bepalen. Met betrekking tot de lange termijn beargumenteren we in dit hoofdstuk dat ondernemingen een bepaalde hoeveelheid kasmiddelen wensen aan te houden uit voorzorg. De mogelijkheid van toekomstige problemen bij het aantrekken van extern kapitaal speelt hierin een belangrijke rol. Met name die ondernemingen die verwachten dat extern kapital voor hen erg duur of zelfs geheel gerantsoeneerd zal zijn, hebben het sterkste motief om kasmiddelen uit voorzorg op te potten. Met betrekking tot de korte termijn is er daarnaast een sterk passief element aanwezig in de bepaling van de kasmiddelen van de onderneming. Toevloeiende middelen worden namelijk makkelijk in liquide vorm bewaard, terwijl uitgaven veelal automatisch voorgefinancierd worden uit deze middelen. Desondanks doen ondernemingen ook al op de korte termijn 
moeite om kasmiddelen te laten bewegen richting de optimale waarde op de lange termijn. $\mathrm{Zij}$ willen zelfs op de korte termijn hun lange termijn doelstellingen duidelijk niet te ver uit het oog verliezen. Dit alles suggereert dat uitermate liquide ondernemingen weliswaar op een bepaald moment ongevoelig kunnen lijken voor de problemen die zich voordoen bij het aantrekken van externe financiering, maar mogelijk in de toekomst dermate grote restricties verwachten dat zij zich nu all zuinig gedragen ondanks hun ogenschijnlijke rijkdom.

Het korte termijn aanpassingsproces van kasmiddelen naar optimale lange termijn niveaus wordt in meer detail onderzocht in hoofdstuk 6 . We houden in dit hoofdstuk rekening met het zeer flexibele karakter van kasmiddelen, hetgeen deze balanspost tot een uitstekende schokdemper maakt. Het is voor de winstmaximaliserende onderneming daarom niet optimaal om kasmiddelen steeds op het optimale niveau te houden en tegelijkertijd de kapitaalgoederenvoorraad en de kapitaalstructuur frequent te moeten aanpassen. Aanpassing van kasmiddelen vormt namelijk een relatief goedkoop alternatief en kan de noodzaak tot aanpassing van laatstgenoemde beslissingvariabelen uitstellen. Tegelijkertijd lokt dit wel de vraag uit, op welk moment aanpassing van de kasmiddelen richting lange termijn optimum wél van primair belang wordt. Dit is uiteraard een belangrijke vraag, aangezien het een indicatie geeft van hoeveel variatie in kasmiddelen 'normaal' is in de zin dat het bijvoorbeeld het investeringsgedrag van de onderneming niet beïnvloedt. Het empirische bewijs in hoofdstuk 6 geeft aan dat deze variatie vrij groot mag zijn; ondernemingen laten de kasmiddelen vrij ver afwijken van het optimale niveau op de lange termijn, zonder wezenlijke pogingen te doen om hier snel naar terug te keren. Bij té grote afwijkingen wordt korte termijn aanpassing echter van primair belang. Dan volgt zeer snelle aanpassing van kasmiddelen richting het optimale niveau.

In hoofdstuk 7 worden deze bevindingen gekoppeld aan de analyse van het onderlinge verband tussen investeren en financieren dat centraal stond in het eerste deel van deze studie. Hieruit volgen twee belangrijke inzichten. In de eerste plaats versehaffen geobserveerde hoeveelheden kasmiddelen geen inzicht in de mate waarin ondernemingsinvesteringen afhankelijk zijn van de aanwas van interne middelen. We leveren hiervoor in dit hoofdstuk zowel theoretisch als empirisoh bewijs. Intuiltief volgt dit inzicht uit het feit dat de motivatie voor de onderneming om kasmiddelen aan te houden voorkomt uit dezelfde factor die ook bijdraagt aan de verklaring waarom investeringen gevoelig zijn voor veranderingen in interne middelen: de mate van informatieproblemen tussen ondernemingen en kapitalmarkten. De geobserveerde hoeveelheden kasmiddelen kunnen derhalve niet als vrij besteedbare middelen worden beschouwd, op afroep beschikbaar ter financiering van nieuwe investeringen. Het tweede belangrijke inzicht van dit hoofdstuk heeft betreft de rol die 
overschotten en tekorten van kasmiddelen - ten opzichte van het optimale niveau - spelen in de gevoeligheid van investeringen voor winsten. In tegenstelling tot de totaal geobserveerde hoeveelheden kasmiddelen kunnen we deze afwijkingen wél als vrij besteedbare middelen beschowwen. Theoretisch verschaffen ze daarmee een betere indicatie van de mate waarin een onderneming afhankelijk is van de winsten ter financiering van haar actuele investeringen. Empirisch bewijs ondersteunt deze gevolgtrekking: voor financieel gezonde ondernemingen zien we dat een tekort aan kasmiddelen gepaard gaat met een sterke gevoeligheid van investeringen voor aanwas van interne middelen, terwijl deze gevoeligheid afwezig is wanneer er sprake is van een overschot aan kasmiddelen. 
$\therefore$

$\therefore \because$

$\therefore \quad \therefore$ 


\section{Professional Curriculum Vitae}

Wouter Allard Bruinshoofd was born August 14, 1975 in Velp, the Netherlands. He attended secondary school at Ulenhof College in Doetinchem between 1987 and 1993. Between 1993 and 1998, he was enrolled in the International Economic Studies programme at Maastricht University. During his studies he spent one semester at the University of Western Ontario in London, Canada through the UM exchange programme. In 1998 he was visiting scholar in the institute of economics of the Czech National Bank in Prague, Czech Republic, where he wrote his final thesis on exchange rate management in transforming economies. He graduated cum laude later that year. After a short spell as junior researcher at the Research Centre for Education and the Labour Market (ROA), he joined the department of economics of Maastricht University as a part-time lecturer in September 1998. Teaching expertise covers various courses in macro-, monetary, and financial economics. In addition to teaching, he worked on his Ph.D. thesis, which resulted in the present study. On January 1, 2003 he joined the research department of De Nederlandsche Bank (Netherlands central bank). 